\title{
AVALIAÇÃO DO CRESCIMENTO, COMPONENTES PRODUTIVOS E COMPOSIÇÃO MINERAL DE TRÊS GRAMÍNEAS FORRAGEIRAS TROPICAIS
}

ALLAN KARDEC BRAGA RAMOS

Engenheiro Agrônomo

Orientador: Herbert Barbosa de Mattos

Dissertação apresentada à Escola Superior de Agricultura "Luiz de Queiroz", da Universidade de São Paulo, para a obtenção do título de Mestre em Agronomia. Área de Concentração: Ciência Animal e Pastagens.

\section{PIRACICABA}

Estado de São Paulo - Brasil

Fevereiro - 1997 
Dados Internacionais de Catalogação na Publicacão (CIP) DIVISĀo dE BIBLIOTECA E DOCUMENTAÇÃo - Campus "Luiz de Queiroz"/USP

\section{Ramos, Allan Kardec Braga}

Avaliação do crescimento, componentes produtivos e composição mineral de três gramineas forrageiras tropicais / Allan Kardec Braga Ramos. - Piracicaba, 1997.

152 p. : il.

Dissertação (mestrado) - - Escola Superior de Agricultura Luiz de Queiroz, 1997. Bibliografia.

1. Graminea forrageira tropical - Avaliação I. Título 


\section{AVALIAÇÃO DO CRESCIMENTO, COMPONENTES PRODUTIVOS E COMPOSIÇÃO MINERAL DE TRÊS GRAMÍNEAS FORRAGEIRAS TROPICAIS}

\section{ALLAN KARDEC BRAGA RAMOS}

Aprovada em: 22.04.1997

Comissão julgadora:

Prof. Dr. Herbert Barbosa de Mattos

Instituto de Zootecnia-SAA

Prof. Dr. Francisco Antonio Monteiro

ESALQ-USP

Prof. Dr. Rodolfo Godoy

EMBRAPA-CPPSE

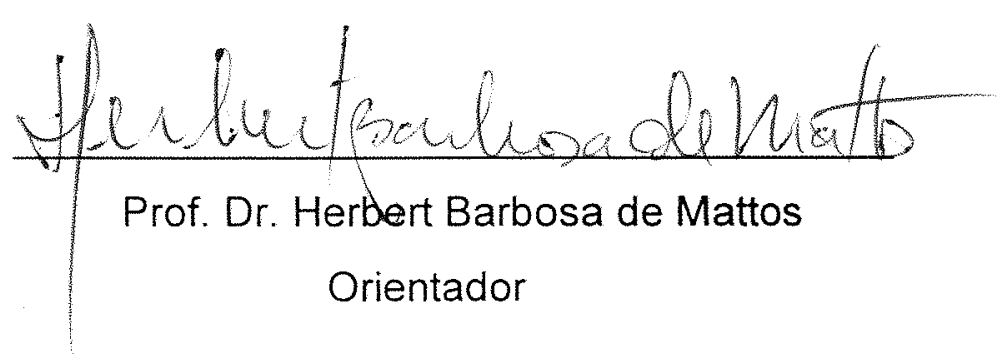




\title{
À minha avó Conceição (in memorian) \\ e ao meu tio Gerardo (in memorian), dedico.
}

\begin{abstract}
Ainda que eu falasse a língua dos homens e dos anjos, e não tivesse amor, seria como o metal que soa ou como o sino que tine. $E$ ainda que tivesse o dom de profecia, conhecesse todos os mistérios, toda a ciência e tivessse toda a fé, sem amor eu nada seria.
\end{abstract} ( Coríntios, 13)

Aos meus pais, Magalhães e Isalena, e irmãos, Allan Karlos, Fabíola e Anna Karla, ofereço. 


\section{AGRADECIMENTOS}

- A Deus por esta conquista;

- Ao Prof. Dr. Herbert Barbosa de Mattos pela orientação, compreensão e serenidade;

- À Escola Superior de Agricultura "Luiz de Queiroz" pela oportunidade de treinamento;

- À Fundação Coordenação de Aperfeiçoamento de Pessoal de Nível Superior (CAPES) pela bolsa de estudos concedida;

- Ao Instituto de Zootecnia pelo suporte oferecido no desenvolvimento deste trabalho;

- Aos funcionários do Instituto de Zootecnia, Antonio Marco Pigatto, Flávio Rubens de Jesus, Márcio Antônio Ramos e José Américo Filho pelo auxílio nas avaliações de campo e análises químicas.

- Ao Agrônomo Daniel Hübbner Marques pelo auxílio na instalação dos experimentos;

- Aos professores, colegas de curso e moradores da Vila Estudantil que pelos ensinamentos, amizade e companheirismo, tornaram a convivência mais agradável e engrandecedora;

- Ao Dr. Rodolfo Godoy e ao Prof. Dr. Francisco Antonio Monteiro, membros da banca examinadora, pelas críticas e sugestões apresentadas;

- Ao amigo Dr. Esteban Alberto Pizarro pela compreensão e facilidades oferecidas para a conclusão deste trabalho;

- A todos a minha eterna gratidão. 


\section{SUMÁRIO}

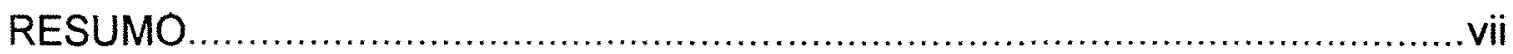

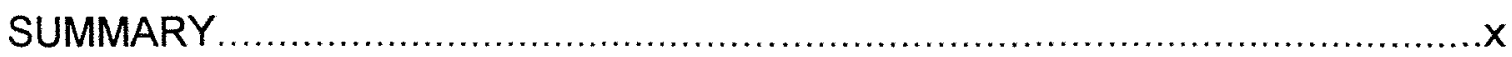

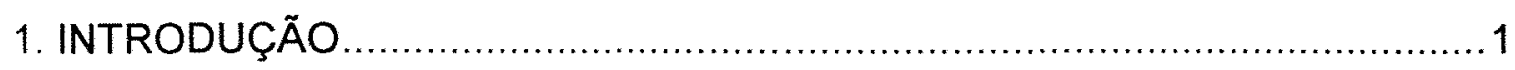

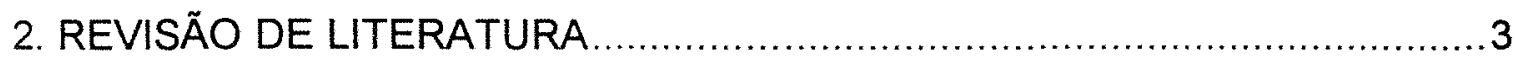

2.1. Gramíneas tropicais: recursos genéticos para a formação de pastagens..3

2.2. Produção de forragem: fatores condicionantes em pastagens cultivadas .. 8

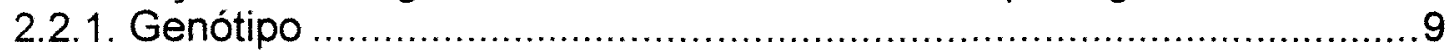

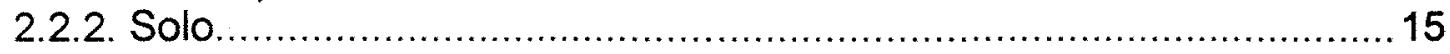

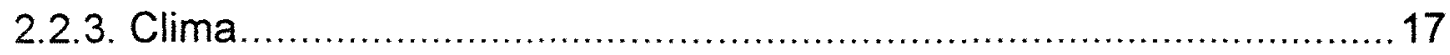

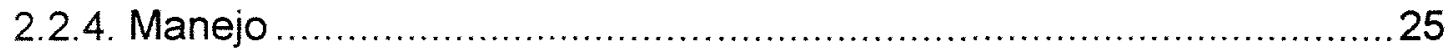

2.3. Componentes da produção de forragem em gramíneas: variações com

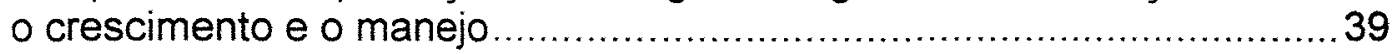

2.3.1. População de plantas ............................................................... 40

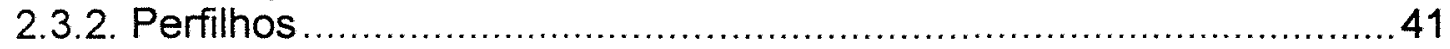

2.3.3. Folha, colmo e material senescido ...........................................44

2.4. Teores de nutrientes minerais em plantas forrageiras ..........................47

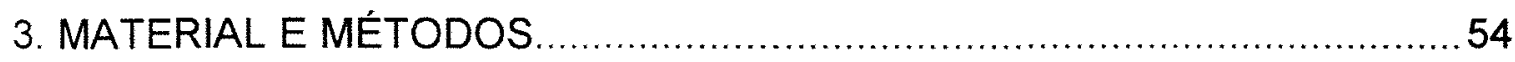

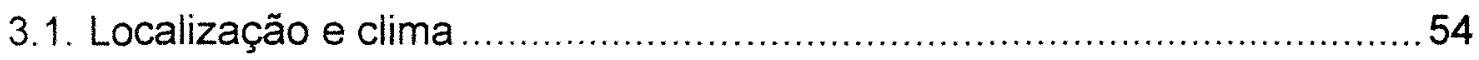

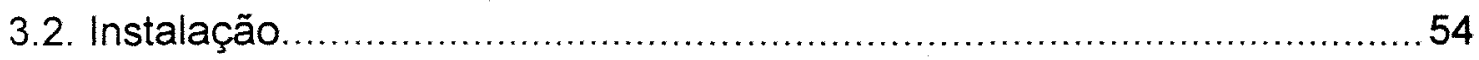

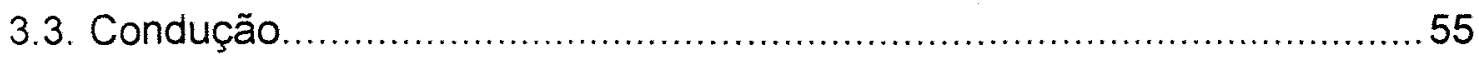

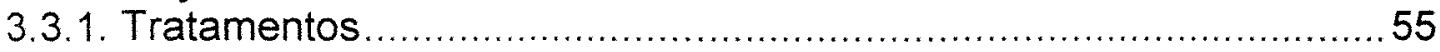

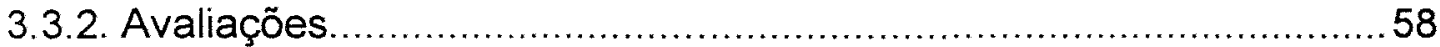

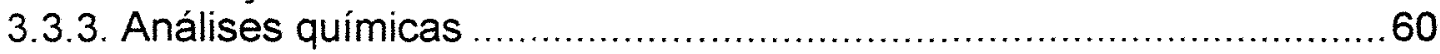

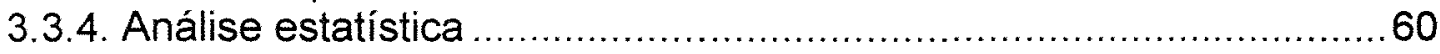

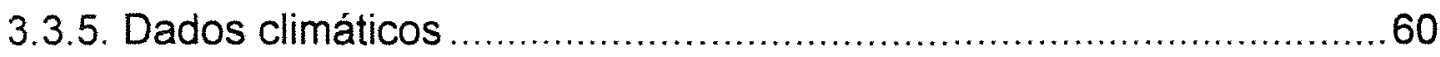

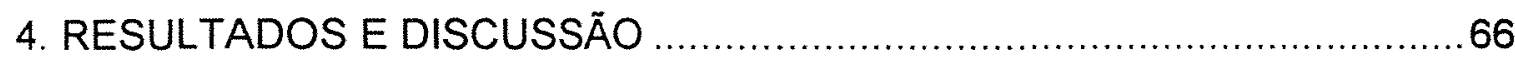

4.1. Crescimento e componentes da produção de forragem........................66

4.1.1. Panicum maximum cultivar Aruana .............................................66

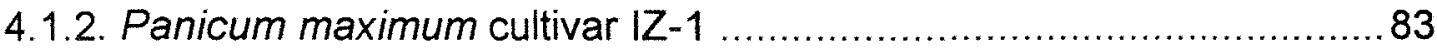

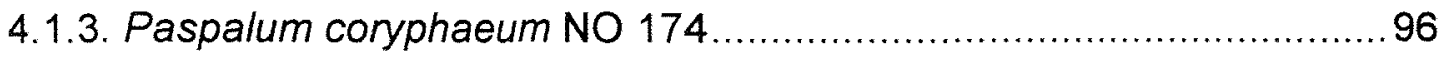

4.2. Teores de nutrientes minerais ...................................................... 110

4.2.1. Panicum maximum cultivar Aruana ........................................... 110

4.2.2. Panicum maximum cultivar $\mid Z-1$............................................116

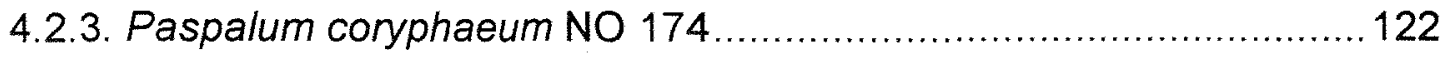




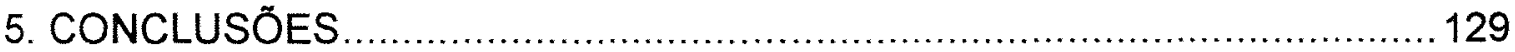

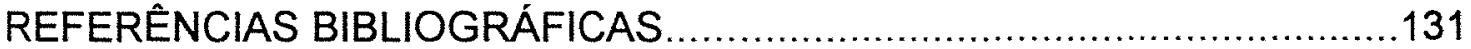

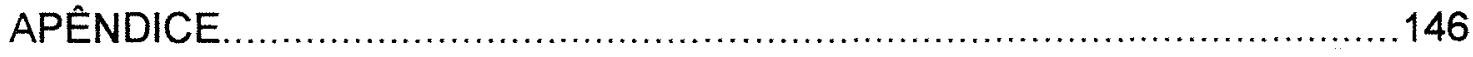




\title{
AVALIAÇÃO DO CRESCIMENTO, COMPONENTES PRODUTIVOS E COMPOSIÇÃO MINERAL DE TRÊS GRAMINEAS FORRAGEIRAS TROPICAIS
}

\author{
Autor: Allan Kardec Braga Ramos \\ Orientador : Prof. Dr. Herbert Barbosa de Mattos
}

\section{RESUMO}

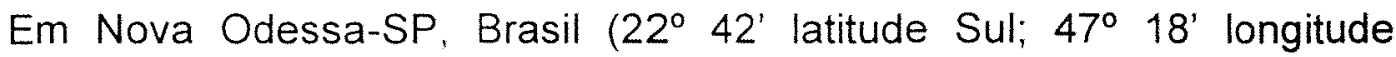
Oeste, $550 \mathrm{~m}$ altitude), as gramineas Panicum maximum Jacq. cultivar Aruana, Panicum maximum Jacq. cultivar IZ-1 e Paspalum coryphaeum Trin. NO 174 foram individualmente avaliadas acerca da produção cumulativa de forragem, componentes da produção e teores de nutrientes minerais, quando em crescimento livre de desfolhas.

Os experimentos foram instalados a partir do final do mês de agosto de 1993, em pastagens já estabelecidas de cada gramínea, num solo classificado como Podzólico vermelho amarelo variação Laras. Definindo o início dos intervalos de crescimento, efetuou-se nas áreas o corte de uniformização da parte aérea e a remoção do material, aplicando-se em seguida o equivalente a $100 \mathrm{~kg} \mathrm{ha}^{-1}$ de $\mathrm{N}, 35 \mathrm{~kg} \mathrm{ha}^{-1}$ de $P$ e $50 \mathrm{~kg} \mathrm{ha}^{-1}$ de $\mathrm{K}$, tendo como fontes o sulfato de amônio, o superfosfato simples e o cloreto de potássio, respectivamente.

As avaliações foram efetuadas nos intervalos de $4,+6,+8 ;+14$ e 22 semanas de crescimento, em parcelas de 4,0 x 4,0 m, dispostas ao acaso em três blocos. As variáveis respostas consideradas foram: a altura da planta, a densidade de perfilhos, o peso médio dos perfilhos, a produção de matéria 
seca da parte aérea, a produção de matéria seca de folhas vivas, colmos, material senescido, e forragem. Também avaliou-se a porcentagem de eliminação dos meristemas apicais e a forragem produzida na rebrota, após 7 e 28 dias, respectivamente, da amostragem efetuada para a estimativa dos componentes da produção. Os teores dos nutrientes minerais $\mathrm{N}, \mathrm{P}, \mathrm{K}, \mathrm{Ca}, \mathrm{Mg}$, $\mathrm{S}, \mathrm{B}, \mathrm{Cu}, \mathrm{Fe}, \mathrm{Mn}$ e $\mathrm{Zn}$ foram determinados nas folhas, e os teores de $\mathrm{N}$ analisados nos colmos.

Após a análise de regressão, o comportamento das variáveis resposta foi expressado através de modelos polinomiais, tendo como variável independente os intervalos de crescimento avaliados em semanas.

Pode-se concluir que no crescimento ao início da estação chuvosa:

A produção de forragem nas gramineas Panicum maximum cultivar Aruana, Panicum maximum cultivar IZ-1 e Paspalum coryphaeum Trin. NO 174 ocorreu com a participação relativa crescente de colmos e material senescido, e decrescente para as folhas;

Em 22 semanas de crescimento a disponibilidade de folhas na forragem foi crescente para o Panicum maximum cultivar $I Z-1$, enquanto que para 0 Panicum maximum cultivar Aruana e para o Paspalum coryphaeum NO 174 decresceu após um limite de tempo;

A densidade de perfilhos diminuiu com o aumento no intervalo de crescimento sem desfolhas no Panicum maximum cultivar Aruana e no Panicum maximum cultivar $\mid Z-1$, enquanto que no Paspalum coryphaeum Trin. NO 174 não apresentou variações;

Desfolhas efetuadas após 8 semanas de crescimento reduziram a produtividade da rebrota subsequente;

Os teores dos nutrientes minerais nas folhas apresentaram comportamento diferenciado com o crescimento; 
Para maior rendimento da forragem acumulada e da rebrota subsequente, as desfolhas deverão ocorrer no máximo com 8 semanas de crescimento, no inicio da estação chuvosa, para o Panicum maximum cultivar Aruana e para o Paspalum coryphaeum NO 174, enquanto que para o Panicum maximum cultivar IZ-1 pode se estender por até 14 semanas de crescimento. 


\title{
GROWTH EVALUATION, YIELD COMPONENTS AND MINERAL NUTRIENT CONTENT IN THREE TROPICAL FORAGE GRASSES
}

\author{
Author: Allan Kardec Braga Ramos \\ Adviser: Prof. Dr. Herbert Barbosa de Mattos
}

\section{SUMMARY}

In Nova Odessa, São Paulo State, Brazil (22 $42^{\prime}$ latitude S; $47^{\circ} 18^{\prime}$ longitude $W ; 550 \mathrm{~m}$ altitude), the grasses Panicum maximum Jacq. cultivar Aruana, Panicum maximum Jacq. cultivar $\mathrm{Z}$-1 and Paspalum coryphaeum Trin. NO 174 were evaluated in individual trials in which the cumulative forage yield, yield components and mineral nutrient contents were associated to continuous growth. The trials were carried out in early growth season on a sward with these grasses on an Ultissol. After a homogeneing cut, ammonium sulphate, ordinary superphosphate and potassium chloride were applied to the experiments to supply $100 \mathrm{~kg} \mathrm{~N} \mathrm{ha}^{-1}, 35 \mathrm{~kg} \mathrm{P} \mathrm{ha}^{-1}$ and $50 \mathrm{~kg} \mathrm{~K} \mathrm{ha}^{-1}$, respectively.

The grasses were evaluated during the rainy season in intervals of growth of $4,+6,+8,+14$ and 22 weeks using $4.0 \times 4.0 \mathrm{~m}$ plots. The experiments were set in a randomized block design with three replications. The following parameters were evaluated: sward height, tiller density, average tiller weight, dry matter yield of plant top, leaves, culms, dead tissue and total forage yield, as well as the percentage of elimination of shoot apex and dry matter yield at 28 days regrowth after yield components evaluations. Nitrogen content was 
determined in culms and leaf tissue, and $\mathrm{P}, \mathrm{K}, \mathrm{Ca}, \mathrm{Mg}, \mathrm{S}, \mathrm{B}, \mathrm{Cu}, \mathrm{Fe}, \mathrm{Mn}$ and $\mathrm{Zn}$ were determined in leaf tissue.

Total forage yield for Panicum maximum Jacq. cultivar Aruana, Panicum maximum Jacq. cultivar $\mathrm{ZZ}-1$ and Paspalum coryphaeum Trin. NO 174 was mainly related with culms and dead tissue yield with a decreasing participation of green leaves as the growing season advanced.

At 22 weeks of growth, the contribution of green leaves was maintained in Panicum maximum Jacq. cultivar $\mid Z-1$. The opposite occured for the green leaves fraction in Panicum maximum Jacq. cultivar Aruana and Paspalum coryphaeum Trin. NO 174

When plots of Panicum maximum Jacq. cultivar Aruana, Panicum maximum Jacq. cultivar $\mathrm{Z}-1$ were not cut, the contribution of the number of tillers decreased with time, meanwhile in Paspalum coryphaeum Trin. NO 174 tiller number was not significantly affected.

Accumulated dry matter yield was significantly affected when cutting intervals were taken place after eight weeks of regrowth.

The mineral content in the green leaves fraction changed within grasses and with plant age.

In order to increase yield efficiency and sward stability Panicum maximum Jacq. cultivar Aruana and Paspalum coryphaeum Trin. NO 174 need to be harvested with a maximum eight weeks regrowth intervals. On the other hand, the late flowering type grass Panicum maximum Jacq. cultivar IZ-1 could be cut at 14 weeks regrowth intervals without affecting yield and sward stability. 


\section{INTRODUÇÃO}

A produção animal baseada em pastagens cultivadas está submetida a forte competição com outras atividades do setor agrícola, em função dos índices zootécnicos registrados. Além disso, o valor da terra, o crescimento demográfico, a conservação/sustentabilidade dos recursos naturais e a necessidade de redução nos custos de produção também demandam a evolução na produtividade animal.

No contexto onde a forragem é a matéria-prima, as instituições de pesquisa vêm contribuindo através da seleção e/ou melhoramento genético em espécies promissoras, e no desenvolvimento e validação de práticas de manejo para o sistema solo-planta-animal. No Estado de São Paulo, o trabalho de introdução, seleção e avaliação de espécies forrageiras realizado pelo Instituto de Zootecnia (IZ) possibilitou o lançamento dos cultivares de Panicum maximum Jacq. Colonião IZ-1 e Aruana IZ-5, bem como a identificação como promissor do genótipo Paspalum coryphaeum Trin. NO $174^{1}$. No processo de avaliação de germoplasma forrageiro e mesmo após o lançamento de um cultivar, muitas questões acerca da produção e aproveitamento da forragem ainda terão que ser investigadas, de modo a maximizar a produtividade da pastagem e do animal.

A produção de forragem, na condição de processo biológico dinâmico, decorre da interação entre o genótipo em uso e o ambiente, sendo marcante o efeito das condições climáticas sobre o crescimento e o desenvolvimento das plantas, cujo maior reflexo é observado na estacionalidade da produção

${ }^{1}$ NO 174 - Número de registro do genótipo na coleção do Instituto de Zootecnia em Nova Odessa, São Paulo 
Nos sistemas intensivos de produção a capacidade de suporte das pastagens deve ser elevada, sendo o maior rendimento em produto animal definido no período de máximo crescimento da forrageiras, pois procura-se aumentar a eficiência no aproveitamento das condições climáticas favoráveis e potencializar o efeito de práticas de manejo, como a adubação. A estacionalidade na oferta de volumoso torna-se mais acentuada, mas é minimizada ou superada por práticas como a fenação, a ensilagem ou, quando possível, o cultivo de forrageiras de inverno.

Em decorrência das condições climáticas favoráveis ao acúmulo de matéria seca, da idade e do desenvolvimento morfológico, a planta forrageira experimenta alterações nos atributos produtivos e nutricionais, cujo comportamento e magnitude necessitam ser melhor compreendidos para a orientação na tomada de decisões acerca do manejo visando melhor aproveitamento da forragem acumulada. Nesta situação, o comportamento entre e dentro das espécies tende a diferir e assume maior importância nos sistemas intensivos de produção baseados em pastagens.

Este trabalho objetivou avaliar a dinâmica no acúmulo de forragem, nos componentes da produção e nos teores de nutrientes minerais das gramíneas Panicum maximum Jacq. cultivar IZ-1, Panicum maximum Jacq. cultivar Aruana e Paspalum coryphaeum Trin. NO 174, quando em crescimento livre de desfolhas no início da estação de crescimento. 


\section{REVISÃo DE LITERATURA}

\subsection{Gramíneas tropicais: recursos genéticos para a formação de pastagens}

Com cerca de 10.000 espécies distribuídas em 620 gêneros, as gramíneas predominam na fisionomia das pastagens graças às peculiaridades evolutivas na morfofisiologia que permitem o crescimento e a adaptação ao regime de desfolhas. Na flora do Brasil é estimada a existência de 150 gêneros de gramineas (Langer, 1974; Rocha, 1991; Valls, 1994).

Apesar do elevado número de espécies, na década de 60 as pastagens cultivadas no mundo eram constituídas quase que totalmente por 40 espécies, sendo que nas regiões tropicais e subtropicais predominavam 15 espécies (Rodrigues, 1986; Rocha, 1991). Mais recentemente, com a demanda por genótipos mais produtivos, com maior adaptação a condições mais especificas de ambiente e manejo, e o maior conhecimento dos recursos genéticos disponiveis, cerca de 100 espécies eram utilizadas ou foram relatadas, pelo potencial agronômico, como promissoras para a formação de pastagens. Deste total, 45 espécies seriam para uso nas condições tropicais e subtropicais (Rocha, 1991).

No Brasil, a pecuária na faixa tropical também tem sua exploração baseada em um número reduzido de espécies, predominantemente exóticas e que foram responsáveis pela "africanização" das áreas pastoris. As espécies pioneiras de maior expressão foram Melinis minutiflora Pal de Beauv, 
Hyparrhenia rufa Ness e Panicum maximum Jacq.. Posteriormente, espécies de outros gêneros como Digitaria, Setaria e Cynodon foram introduzidas, com destaque para aquelas do gênero Brachiaria (Zimmer, 1986; Rocha, 1991), sendo a Brachiaria decumbens Stapf. um marco na expansão da pecuária na região de domínio dos cerrados. Com a área cultivada em expansão, Santos Filho (1990) estimou que as espécies do gênero Brachiaria respondiam por 70 $\%$ da quantidade de sementes de forrageiras comercializadas anualmente no país, refletindo a adaptação deste gênero, e a substituição dos cultivares de outros gêneros de introdução mais remota.

No limitado número de espécies que compõe o mosaico das pastagens cultivadas no país, além das espécies do gênero Brachiaria, ainda ocupa lugar de destaque a espécie Panicum maximum Jacq., principalmente pelas características agronômicas e nutricionais. A redução que vem sendo observada na participação relativa em área de Panicum maximum, em parte decorre das maiores exigências no manejo da fertilidade do solo, em geral não atendidas, em relação às espécies de Brachiaria (Werner, 1986a). O declínio na produtividade das pastagens quando não há a reposição dos nutrientes no sistema é fato comum entre as espécies cultivadas, mas em Panicum maximum é mais evidente por conta do elevado potencial para a produção de forragem, cujos índices a credenciam para sistemas intensivos de produção baseados em pastagens.

A importância histórica de Panicum maximum na pecuária nacional foi evidenciada por Aronovich (1995) ao listar 17 genótipos já difundidos pelo país. Nesta lista não estavam incluídos os cultivares lançados pelo Instituto de Zootecnia (IZ-1 e Aruana), pelo Instituto Agronômico de Campinas (Centenário e Centauro) e pela Empresa Brasileira de Pesquisa Agropecuária - EMBRAPA (Vencedor, Tanzânia-1 e Mombaça) (Usberti Filho, 1987; Instituto de Zootecnia, 1989; Jank, 1994). Skerman \& Riveros (1992) listaram 16 cultivares registrados em outros países para Panicum maximum Jacq., e um cultivar para Panicum maximum var, trichoglume (K. Schum.) C.E. Hibberd. 
No Estado de São Paulo, em levantamento efetuado por Carriel et al. (1979) em 1976, Panicum maximum ocupava $32 \%$ da área com pastagens cultivadas. Ghisi et al. (1989), citando Rocha ${ }^{2}$, relataram a ocorrência de Panicum maximum em $82 \%$ dos municípios do Estado de São Paulo, para um total de 311 municípios incluidos no levantamento.

Outro indicativo da importância histórica, atual e futura, da espécie Panicum maximum na pecuária nacional, foi dado com a ampliação da base genética existente através de expedições de coleta de germoplasma em vários países da África, pois dos genótipos coletados com potencial forrageiro, as instituições nacionais de pesquisa priorizaram no intercâmbio a espécie Panicum maximum (Jank, 1994) e o gênero Brachiaria (Valle \& Miles, 1994).

A recente introdução no País das coleções de Panicum maximum e Brachiaria spp. ampliou a variabilidade genética a ser explorada pelas instituições de pesquisa em gramíneas forrageiras. Todavia, as áreas pastoris ainda estão expostas, conforme salientou Valls (1994), a uma enorme vulnerabilidade, face a estreita base genética em uso. Embora em pequena escala já merecesse a atenção de alguns pioneiros na pesquisa com pastagens no Brasil, as espécies da flora brasileira também passaram, mais recentemente, a ser objeto de interesse para a constituição de pastagens artificiais, visando contribuir para a demanda existente quanto à melhoria na produtividade, estacionalidade da produção e qualidade da forragem, bem como para ampliar a diversidade interespecifica (Valls, 1994). O impulso necessário para este enfoque, em grande parte deveu-se ao maior conhecimento da flora nativa e dos resultados promissores quando ainda se dispunha de uma estreita base genética (Allem \& Valls, 1987; Pott, 1988; Valls, 1992).

No Brasil várias espécies de gramíneas predominam nas áreas com pastagens nativas, mas as ações de coleta concentraram-se nas espécies do gênero Paspalum, em princípio pelo interesse em espécies adaptadas às

\footnotetext{
${ }^{2}$ ROCHA, G.L. Situação das pastagens no Estado de São Paulo - Pastagens naturais e cultivadas. In: CURSO DE MANEJO DE PASTAGENS, 1., Nova Odessa, SP, Brasil, 1985. Anais... Nova Odessa, Instituto de Zootecnia, 1985. p. 2-24.
} 
condições da região subtropical do País, onde naturalmente as espécies ocorriam. Outros determinantes foram a abundância do gênero no pantanal do Estado do Mato Grosso, e os resultados preliminares obtidos numa área de várzea na EMBRAPA-CPAC (Empresa Brasileira de Pesquisa Agropecuária Centro de Pesquisa Agropecuária dos Cerrados) com genótipos provenientes da Região Norte do País e do pantanal, que motivaram a incorporação de novos acessos e o envolvimento de instituições de pesquisa situadas em regiōes de clima tropical (Allem \& Valls, 1987; França-Dantas et al., 1987; Valls, 1992). Cerca de 1.000 acessos foram coletados, que juntamente com outros acessos provenientes do exterior e de expedições de coleta para outras espécies, perfazem um total de 1.580 acessos, conferindo ao gênero Paspalum variabilidade genética em potencial a ser explorada, e a capacidade de reunir o maior número de espécies nativas da flora brasileira e com potencial forrageiro. O germoplasma coletado de Paspalum spp. reúne acessos das cinco regiões do Brasil, porém o maior número de acessos é proveniente das regiões Sul e Centro-Oeste (Valls \& Pozzobon, 1987). Valls \& Coradin (1986) estimaram que nesta coleção devem estar contidas quase a metade das 220 espécies atribuídas ao gênero no país. Martínez et al. (1985), num artigo de revisão, citaram estimativas da existência de cerca de 200 espécies na América tropical. Para grande parte dos acessos coletados não há a definição da espécie, sendo os mesmos denominados apenas por Paspalum sp., demostrando o pouco conhecimento taxonômico do gênero. Todavia os acessos encontram-se ordenados dentro de grupos taxonômicos para o gênero (Valls \& Coradin, 1986; Valls \& Pozzobon, 1987; Valls, 1994).

Face aos resultados obtidos nas condições da região dos Cerrados, o maior número de acessos coletados do gênero está contido nos grupos Plicatula e Virgata, os quais estão sendo avaliados e caracterizados na EMBRAPACPAC, e na EMBRAPA-CPPSE (Pizarro \& Carvalho, 1992; Batista \& Godoy, 1992a,b). Do trabalho de avaliação de parte do germoplasma de Paspalum spp. disponivel já foram identificados genótipos promissores pela EMBRAPA-CPAC e 
pela EMBRAPA-CPPSE, sendo os genótipos predominantemente do grupo Plicatula (Batista \& Godoy, 1992b; Pizarro \& Carvalho, 1992; Batista et al., 1994). Também foram identificados genótipos superiores, a partir de bases genéticas reduzidas, nos Estados do Pará e de Rondônia (Lima \& Gondim, 1982; Oliveira et al.; 1984; Oliveira \& Alves, 1988, Costa et al., 1989a,b), coletados naquela região, e em São Paulo, pelo Instituto de Zootecnia, em coleta no Estado do Mato Grosso (Rocha, 1991). Nestes locais os genótipos não pertencem ao grupo Plicatula, sobressaindo-se, em Nova Odessa-SP, do grupo Quadrifaria, o genótipo da espécie Paspalum coryphaeum Trin. NO 174, pela adaptação agronômica e tolerância à geada (Ghisi ${ }^{3}$ ), e em Rondônia, Paspalum coryphaeum BRA ${ }^{4}-003760$ (FCAP $\left.{ }^{5}-08\right)$, pela produção de forragem e tolerância à cigarrinha-das-pastagens (Deois spp. - Homóptera) (Oliveira et al., 1984; Costa et al., 1988; Costa et al., 1989a,b). Mais recentemente, Batista et al. (1994) ao avaliarem 102 acessos de Paspalum spp., verificaram que o único acesso de Paspalum coryphaeum (BRA-000841) presente na coleção figurou entre os mais produtivos e promissores. Tais atributos têm despertado o interesse das instituições que detêm estes genótipos para as questões agronômicas relativas ao seu aproveitamento como forrageira. Apesar do número reduzido de acessos para esta espécie, Valls (1986) a incluiu numa relação, com 39 espécies brasileiras do gênero que deveriam ser melhor avaliadas. No entanto, Pott (1988) a considerou de baixo valor forrageiro, em relação a outras espécies de gramíneas inventariadas na região do pantanal. No Brasil há registros da ocorrência de Paspalum coryphaeum no Rio Grande do Sul, no Pantanal e no Pará, sugerindo ocorrência dispersa (Araújo, 1971; Lima \& Gondim, 1982; Allem \& Valls, 1987; Pott, 1988).

Nativas da América, as espécies de Paspalum têm o seu aproveitamento predominantemente na condição de componentes de pastagens nativas.

\footnotetext{
${ }^{3}$ GHISI, ODETE M. A. A - Pesquisadora EMBRAPA, comissionada no Instituto de Zootecnia, Nova OdessaSP, na seção de Agronomia de Plantas Forrageiras - Comunicação pessoal.

${ }_{5}^{4}$ BRA - Número de registro do genótipo no Sistema Nacional de Pesquisa Agropecuária.

${ }^{5}$ FCAP - Número de registro do genótipo na coleção da Faculdade de Ciências Agrárias do Pará.
} 
Todavia, algumas espécies foram lançadas como cultivares para as condições de clima subtropical, destacando-se Paspalum notatum Flügge var. saurae Parodi cultivar Pensacola (bahiagrass) que originário da Argentina foi introduzido nos Estados Unidos e na Austrália. Cultivares das espécies Paspalum plicatulum, Paspalum dilatatum e Paspalum commersonii foram citados por Martínez et al. (1985), num trabalho de revisão cobrindo os anos de 1948 a 1984. Também da análise desta revisão, verificou-se a citação de seis cultivares explorados nas condições subtropicais pela tolerância às baixas temperaturas. Todavia, as informações disponíveis sobre desempenho animal, restringiam-se à espécie Paspalum notatum. Para esta mesma espécie tem-se o relato de um cultivar em uso no Brasil (cultivar Pensacola). Porém várias espécies são citadas como principais componentes de pastagens nativas nos Estados do Rio Grande do Sul e Mato Grosso (Prates, 1970; Araújo, 1971; Pott, 1988).

Neste panorama, a tendência a curto e médio prazo é que as áreas com pastagens cultivadas com gramíneas permaneçam com um reduzido número de espécies, porém com a ampliação e substituição de genótipos dentro da espécie Panicum maximum, e a inserção do gênero Paspalum como opção para a diversificação das pastagens através dos futuros lançamentos comerciais decorrentes da exploração da variabilidade genética existente ou gerada nessas grandes coleções.

\subsection{Produção de forragem: fatores condicionantes em pastagens cultivadas}

As pastagens constituem comunidades vegetais cuja produtividade é a conjugação das relações entre os fatores bióticos e abióticos, porém suas relações têm maior grau de complexidade por conta da natureza de seu aproveitamento. O genótipo, o solo, o clima e, quando possível, o manejo dos 
componentes, inclusive dos animais, determinam a expressão e a manutenção dos atributos desejáveis no componente básico, a planta forrageira.

\subsubsection{Genótipo}

A adaptação das espécies forrageiras a um ambiente tem no componente genético o maior determinante na sua ocorrência, dispersão e produtividade. Assim sendo, a variabilidade genética de uma espécie tem sido o fator inicialmente explorado visando ganhos em produtividade.

Um elevado número de acessos numa coleção não implica maior variabilidade genética, pois dependerá da abrangência dos locais de coleta na natureza, bem como das características evolutivas relativas à combinação genética. Embora muitas gramíneas forrageiras sejam predominantemente apomíticas, felizmente há grande variabilidade genética a ser explorada diretamente, através da seleção, ou passivel de ser gerada através de cruzamentos visando melhoramento genético (Savidan, 1987; Valle \& Miles, 1994; Jank, 1994).

A distribuição pelas regiões do Brasil de genótipos de Panicum maximum e de Paspalum spp., relatadas por Aronovich (1995) e Valls \& Pozzobon (1987), respectivamente, são fortes evidências do componente genético definindo o grau de plasticidade frente às condições ambientais.

$\mathrm{Na}$ busca de maior produtividade e novas espécies para a diversificação das pastagens, amenizando problemas relacionados com a estacionalidade da produção, valor nutritivo, susceptibilidade a pragas e respostas a práticas de manejo, tem-se explorado em Panicum maximum e em Paspalum spp. as diferenças entre genótipos através do processo de seleção no âmbito das regiões ou estados do País. Os cultivares IZ-1 e Aruana, de Panicum maximum, e o genótipo NO 174, de Paspalum coryphaeum, são exemplos do trabalho de seleção efetuado no estado de São Paulo. 
O Panicum maximum cultivar $\mathrm{IZ}-1$ apresenta alta produção anual de matéria seca e de boa qualidade, sendo inclusive indicado para a produção de feno. Ferrari Júnior (1994) relatou produções anuais de matéria seca de $27,8 \mathrm{Mg}$ $\mathrm{ha}^{-1} \mathrm{ano}^{-1}$, com teores de $9,3 \mathrm{~g}(100 \mathrm{~g})^{-1}$ de proteína bruta, obtidos com cinco cortes ao longo do ano, nas condições do Estado de São Paulo.

Andrade (1987) relatou alta produção de matéria seca para o cultivar IZ1, quando em crescimento contínuo na estação chuvosa. Neste estudo o cultivar IZ-1 não diferiu do cultivar Tobiatã, com produções acumuladas de matéria seca total (folhas + colmos + material senescido) de 1,$0 ; 2,6 ; 7,4 ; 11,7 ; 13,6$; e 15,5 $\mathrm{Mg} \mathrm{ha}{ }^{-1}$ aos $28,56, \quad 84,112,140$ e 168 dias de crescimento, respectivamente. Até 140 dias de crescimento não havia material senescido compondo a forragem amostrada, sendo que após este intervalo de crescimento o cultivar IZ-1 apresentou menor tendência ao acúmulo de material senescido que o cultivar Tobiatã.

Gomide \& Zago (1980) estimaram para o cultivar Colonião em crescimento contínuo na estação chuvosa produções de 2,1 ; 3,1 ; e $4,2 \mathrm{Mg}^{\text {ha- }}$ ${ }^{1}$ de MS aos 28,42 e 56 dias de crescimento, respectivamente.

Andrade et al. (1991), comparando o cultivar IZ-1 com o cultivar Tobiatã, adotando cortes a cada 42 dias na estação chuvosa, não encontraram diferenças entre os dois cultivares em dois anos de avaliação. Nestas condições a produtividade média no período foi de $7,7 \mathrm{Mg} \mathrm{ha}^{-1}$ de MS.

O Panicum maximum cultivar Aruana apresenta menor porte e colmos mais finos em relação aos cultivares Colonião e $I Z-1$, o que permite maior aproveitamento desta fração quando em estádios mais avançados de crescimento (Instituto de Zootecnia, 1989; Anônimo, 1994). Em Nova Odessa$\mathrm{SP}$, o cultivar Aruana vem sendo utilizado como a fonte de volumoso para os animais da Seção de Ovinos e Caprinos do Instituto de Zootecnia, sendo elevado o aproveitamento da forragem acumulada

Em Sertãozinho-SP, num latossolo roxo, seis gramíneas foram avaliadas por dois anos sob regime de cortes. Entre elas três cultivares de Panicum 
maximum: Gatton Panic, Green Panic e Aruana. Não se verificaram diferenças entre os cultivares quando submetidos ou não à adubação de manutenção. $O$ cultivar Aruana produziu, em quatro cortes por ano, o equivalente a $12,5 \mathrm{Mg} \mathrm{ha}^{-1}$ $a^{-1}$, sem adubação de manutenção, e $20,6 \mathrm{Mg} \mathrm{ha}^{-1} \mathrm{ano}^{-1}$ de $\mathrm{MS}$, quando adubado com $150 \mathrm{~kg} \mathrm{ha}^{-1}$ de $\mathrm{N}$ (Paulino et al., 1990). Menores produções (10 $\mathrm{Mg} \mathrm{ha}^{-1} \mathrm{ano}^{-1}$ ) foram relatadas por Instituto de Zootecnia (1989) e Anônimo (1994) para este cultivar, porém foi registrada melhor distribuição da produção de forragem ao longo do ano, em relação ao cultivar Colonião.

Em Nova Odessa-SP, seis cultivares de Panicum maximum tiveram seus comportamentos avaliados por dois anos frente à condições de adubação por GHISI et al. (1989). No primeiro ano de avaliação, bem como no total produzido em dois anos, não houve diferenças entre os genótipos. O cultivar IZ-1 produziu $18,3 \mathrm{Mg} \mathrm{ha}^{-1}$, enquanto o cultivar Aruana produziu 14,6 $\mathrm{Mg} \mathrm{ha}^{-1}$ de $\mathrm{MS}$ ao longo do primeiro ano. Todavia no segundo ano o cultivar Aruana foi o menos produtivo com 4,7 Mg ha ${ }^{-1}$, ao passo que o cultivar $\mathrm{IZ}-1$ alcançou $6,0 \mathrm{Mg} \mathrm{ha}^{-1}$ de MS. Diferenças também foram observadas quando consideradas as estações de máximo crescimento, sendo que o cultivar Aruana apresentou 0 menor rendimento, com 12,1 $\mathrm{Mg} \mathrm{ha}^{-1}$, enquanto que o cultivar $\mathrm{IZ-1}$ alcançou $17,8 \mathrm{Mg}$ ha ${ }^{-1}$.

As informações agronômicas sobre Paspalum spp. são escassas quando comparadas com outras espécies forrageiras. Neste gênero a pesquisa é incipiente, sendo ínfima quando considerada a espécie Paspalum coryphaeum Trin.. Em maior número os trabalhos científicos contemplaram Paspalum notatum, a espécie mais difundida (Martínez et al., 1985), cuja expressão é maior nas regiões subtropicais.

Os trabalhos de avaliação agronômica do germoplasma de Paspalum spp. nas condições tropicais iniciaram-se na Região Norte do País pela Faculdade de Ciências Agrárias do Pará (FCAP), face às limitações de desempenho das espécies exóticas. Após expedições de coleta na região e seleção inicial, foram introduzidos 74 genótipos, sendo que apenas 25 foram 
avaliados quanto à produção de forragem, agressividade, profundidade do sistema radicular, vigor da rebrota após pastejo ou fogo, aceitabilidade por bovinos, tolerância à cigarrinha e composição química (Lima \& Gondim, 1982). Deste trabalho foram selecionados os genótipos Paspalum secans FCAP-12 (BRA-003778), Paspalum guenoarum FCAP-43 (BRA-001635), Paspalum plicatulum FCAP-6 (BRA-004375) e Paspalum coryphaeum FCAP-8 (BRA003760) que passaram a ser avaliados em propriedades da região. Quando avaliados no Estado de Rondônia-RO, os genótipos selecionados pela FCAP apresentaram o menor número de ninfas de cigarrinha-das-pastagens ao longo do ano (Oliveira et al. 1984; Oliveira \& Alves, 1988).

A coleção existente na FCAP foi transferida para a EMBRAPA-CPATU (Centro de Pesquisa Agropecuária do Trópico Úmido) e avaliada em parte pela EMBRAPA-CPAC, e embora com resultados promissores para o gênero, os três acessos de Paspalum coryphaeum da coleção não se sobressairam (FrançaDantas et al., 1987). Em Nova Odessa-SP, da coleção de Paspalum spp. existente, destacou-se o Paspalum coryphaeum NO 174 pela adaptação fenotípica e tolerância à geada.

Do levantamento efetuado na literatura sobre Paspalum coryphaeum, tem-se que apenas cinco genótipos estão cadastrados pela EMBRAPACENARGEN (Lima \& Gondim, 1982; França-Dantas et al., 1987; Valls \& Pozzobon, 1987; Oliveira \& Alves, 1988; Batista et al., 1994). Três deles, BRA003760 (FCAP-8), -000375 (FCAP-34), -003867 (FCAP-41), provenientes da Região Norte, e os demais, BRA-010669 e BRA-000841, coletados no pantanal matogrossense. Há fortes indícios de que o genótipo NO 174 seja equivalente ao BRA-010669.

Nas condições ecológicas de Rondônia estão concentrados os estudos agronômicos sobre o Paspalum coryphaeum, que tiveram impulso com os resultados de Lima \& Gondim (1982) e Oliveira \& Santos (1988).

Costa et al. (1988), inicialmente em Ariquemes-RO $(2.000-2.500 \mathrm{~mm}$ ano ${ }^{-1}$ ), avaliaram em pequenas parcelas 49 acessos de gramíneas de cinco 
gêneros, inclusive as quatro espécies de Paspalum provenientes da FCAP, num latossolo amarelo $\left(\mathrm{pH}=4,6 ; \mathrm{P}=2 \mathrm{mg} \mathrm{dm}^{-3}\right)$. Em cinco cortes, Paspalum coryphaeum produziu $8,2 \mathrm{Mg} \mathrm{ha}^{-1}$, Paspalum guenoarum $7,6 \mathrm{Mg} \mathrm{ha}^{-1}$, enquanto que a Brachiaria brizantha cultivar Marandu produziu $9,3 \mathrm{Mg} \mathrm{ha}^{-1}$ de MS. Entre 36 acessos de Panicum maximum, o mais produtivo alcançou $8,3 \mathrm{Mg} \mathrm{ha}^{-1}$.

Em Porto Velho-RO, com 30 genótipos distribuídos em oito gêneros, sendo seis de Paspalum spp., Costa et al. (1989a) submeteram os mesmos a seis cortes por ano quando cultivados num latossolo amarelo adubado com 22 $\mathrm{kg} \mathrm{ha}^{-1}$ de P. Paspalum coryphaeum FCAP-08 (7,3 Mg ha $\left.{ }^{-1}\right)$ e Paspalum guenoarum $\left(7,4 \mathrm{Mg} \mathrm{ha}^{-1}\right)$ foram mais produtivos que Panicum maximum cultivar Tobiatã $\left(5,9 \mathrm{Mg} \mathrm{ha}^{-1}\right)$ e menos produtivos que o cultivar Marandu $\left(7,9 \mathrm{Mg} \mathrm{ha}^{-1}\right) \mathrm{e}$ Andropogon gayanus (9,5 $\mathrm{Mg} \mathrm{ha}^{-1}$ ).

Posteriormente, em Ariquemes-RO, também num latossolo amarelo adubado com $22 \mathrm{~kg} \mathrm{ha}^{-1}$ de $\mathrm{P}$, foi avaliado em cinco genótipos de Paspalum spp. o acúmulo de forragem em intervalos de três semanas nos períodos de máxima e mínima precipitação pluvial. Os resultados de três anos de avaliação foram relatados por Costa \& Oliveira (1992) e Costa \& Oliveira (1994). Em média, para os intervalos de crescimento ( 3 a 12 semanas) nos períodos de máxima e mínima precipitação pluvial os genótipos Paspalum coryphaeum FCAP-8, Paspalum guenoarum FCAP-43 não diferiram entre si. No período de máxima precipitação pluvial o Paspalum coryphaeum FCAP-8 acumulou 0,9; 2,0; 2,6 e 4,2 $\mathrm{Mg} \mathrm{ha}^{-1}$ de $\mathrm{MS}$, respectivamente, com 3, 6, 9 e 12 semanas de crescimento, enquanto que para os mesmos intervalos no período de mínima precipitação pluvial, o acúmulo foi de 0,$5 ; 1,0 ; 1,4$ e $2,1 \mathrm{Mg} \mathrm{ha}^{-1}$ de $\mathrm{MS}$.

Costa et al. (1989a) avaliaram cinco genótipos de Paspalum spp e os cultivares Marandu e Tobiatã, adubados com $22 \mathrm{~kg} \mathrm{ha}^{-1}$ de $P$, em dois locais no Estado de Rondônia (Presidente Médici e Ouro Preto D'Oeste). Nos períodos de máxima e mínima precipitação pluvial registraram o acúmulo de forragem em crescimento contínuo por 12 semanas, em intervalos de três semanas. Na fase de estabelecimento, 12 semanas após a semeadura, as maiores porcentagens 
de cobertura do solo foram alcançadas pelos cultivares Tobiatã e Marandu, juntamente com Paspalum coryphaeum FCAP-08 e Paspalum guenoarum FCAP-43. Para a produção de forragem, nos dois locais os mesmos genótipos se sobressairam. Todavia, os genótipos de Paspalum tenderam a ser menos produtivos após 12 semanas de crescimento no periodo de máxima precipitação pluvial. Paspalum coryphaeum acumulou no periodo de máxima precipitação pluvial em Ouro Preto D'Oeste e Presidente Médici, respectivamente, 2,3 e 0,9; 2,7 e 2,1; 5,0 e 2,8; e 5,9 e 4,4 Mg ha ${ }^{-1}$ de MS, após 3, 6, 9, e 12 semanas de crescimento. No período de mínima precipitação pluvial a produção de forragem em Ouro Preto D'Oeste e Presidente Médici, respectivamente, foi de 1,3 e 0,5; 1,4 e 0,6; 2,5 e 0,6; e 3,0 e 1,0 Mg ha ${ }^{-1}$ de MS, após 3, 6, 9, e 12 semanas de crescimento.

Pizarro \& Carvalho (1992) relataram para 13 acessos de Paspalum spp. , predominantemente do grupo Plicatula, avaliados num solo de várzea (glei pouco úmico), produções acumuladas na estação chuvosa variando de 2 a 29 $\mathrm{Mg} \mathrm{ha}{ }^{-1}$ de MS (tendo nove acessos média superior a $17 \mathrm{Mg} \mathrm{ha}^{-1}$ ) e de 0,5 a 2,3 $\mathrm{Mg} \mathrm{ha} \mathrm{C}^{-1}$ de MS (apenas três acessos com média superior a $2 \mathrm{Mg} \mathrm{ha}^{-1}$ ) na estação seca (5-6 meses). Os mesmos autores também avaliaram 42 genótipos, num latossolo vermelho escuro bem drenado. A forragem acumulada em 10 meses após o estabelecimento e disponível ao final da seca, variou de 0,4 a 4,4 $\mathrm{Mg} \mathrm{ha}^{-1}$ de MS (tendo cinco genótipos com média acima de $2,5 \mathrm{Mg} \mathrm{ha}^{-1}$ ). Neste local, para 47 dias de crescimento no início da estação chuvosa, a forragem acumulada variou de 0,4 a $3,7 \mathrm{Mg} \mathrm{ha}^{-1}$ de MS (cinco genótipos com média acima de $2 \mathrm{Mg} \mathrm{ha}^{-1}$ ). Na mesma estação de crescimento, a forragem acumulada entre dezembro de 1990 e abril de 1991 (5 meses) variou de 1,1 a $18,2 \mathrm{Mg} \mathrm{ha}^{-1}$ de MS (cinco genótipos com média acima de $15 \mathrm{Mg} \mathrm{ha}^{-1}$ ).

Batista \& Godoy (1992b) também avaliaram, em São Carlos-SP, 42 genótipos de Paspalum spp. durante o periodo de máxima e mínima precipitação pluvial. A coleção, em média, produziu $11,2 \mathrm{Mg} \mathrm{ha}^{-1} \mathrm{ano}^{-1}$ de MS (oito genótipos com médias entre 15,7 a $23,5 \mathrm{Mg} \mathrm{ha}^{-1}$ ano $^{-1}$ ), em quatro cortes. 
Também em São Carlos-SP, desta vez com 102 genótipos, Batista et al. (1994) identificaram sete acessos com maior produção anual de forragem em quatro cortes. A produtividade nestes genótipos variou de 13,8 a 21,5 $\mathrm{Mg} \mathrm{ha}^{-1}$, sendo o Paspalum coryphaeum BRA-000841 o mais produtivo.

A descrição de alguns caracteres morfológicos do cultivar $\mid Z-1$ foi apresentada por Andrade (1987), e para o cultivar Aruana, por Anônimo (1994) e Instituto de Zootecnia (1989). Araújo (1971) descreveu o Paspalum coryphaeum que ocorria no Estado do Rio Grande do Sul, porém o exemplar descrito parece diferir morfologicamente do Paspalum coryphaeum NO 174, um vez que no primeiro, as bainhas são descritas como glabras, enquanto que no último existem pêlos que tornam-se bastante rígidos nos estádios mais avançados de crescimento. A espécie Panicum maximum foi descrita por Skerman \& Riveros (1992), enquanto que Paspalum spp. foram descritas por Martínez et al. (1985).

Descritores morfológicos e agronômicos estão sendo avaliados para a caracterização de coleções de Paspalum spp., em São Carlos-SP, (Batista et al., 1992a) e para Panicum maximum, em Campo Grande-MS (Jank, 1994).

\subsubsection{Solo}

As características e propriedades físicas e químicas do solo definem a sua fertilidade, refletindo-se no nível de produtividade e nas práticas exigidas para a sua manutenção. Do ponto de vista físico o solo influencia diretamente na resistência mecânica ao crescimento das raízes e na dinâmica da água e gases. Por sua vez, do ponto de vista químico afeta a disponibilidade e absorção dos nutrientes pelas plantas, havendo forte interação entre os fatores físicos, químicos e biológicos do sistema.

A capacidade de intervenção num solo com restrições de natureza física, é limitada, enquanto que no componente químico são maiores as possibilidades técnicas, porém demandando viabilidade econômica. Os solos explorados com 
pastagens no Brasil, apresentam como principais limitações de ordem química, a acidez, os baixos teores de bases trocáveis e fósforo e elevadas concentrações de alumínio e manganês (Raij, 1991). Face a estas limitações, a baixa viabilidade econômica das adubações em algumas regiões e a extensão das áreas com pastagens, procurou-se superar estas restrições com a busca de germoplasma adaptado ao uso mínimo de insumos (Spain \& Salinas, 1985). Todavia, gramíneas bem adaptadas às condições de clima tropical, como Panicum maximum, não expressam todo o potencial ou a estabilidade na produção de forragem. No entanto, passam a ser espécies chaves nos sistemas intensivos de produção, onde os maiores níveis de produtividade são determinados pelo maior aporte de nutrientes.

Segundo Skerman \& Riveros (1992), Panicum maximum vegeta em vários tipos de solo, porém preferencialmente nos mais "férteis", apresentando pouca tolerância à salinidade, inundações e secas intensas. A essas características Alcântara et al. (1993) acrescentaram no zoneamento edáfico para espécies forrageiras no Estado de São Paulo, que o uso preferencial devesse ocorrer em áreas de relevo plano a suavemente ondulado, pela baixa capacidade de proteção contra à erosão do solo em relação a outras espécies.

Pott (1988) ao inventariar espécies de Paspalum nativas do pantanal registrou ampla ocorrência das espécies entre classes texturais e regimes de inundação a que estão submetidos os solos daquela região. Paspalum coryphaeum teve registro de ocorrência em solo argiloso e muito alagado. Araújo (1971) também descreveu Paspalum coryphaeum como "grande macega que habita banhados" no Estado do Rio Grande do Sul. Apesar disso, num glei pouco húmico o Paspalum coryphaeum não se sobressaiu frente a genótipos do mesmo gênero, enquanto que em São Paulo apresentou maior produção num solo bem drenado (França-Dantas et al., 1987; Batista et al., 1994).

O efeito do solo sobre a produtividade, para um dado genótipo, numa dada condição climática, manifesta-se em maior escala pelas diferenças entre a disponibilidade original dos nutrientes ou pela interação dos mesmos com o solo 
após a aplicação. Deste modo, o enfoque do solo como um reservatório de nutrientes tem sido o principal fator de manejo explorado. São poucos os trabalhos que permitem evidenciar apenas o efeito do tipo de solo numa mesma condição climática. Evidências do efeito do solo, e possivelmente do microclima e de ano, podem ser sugeridas a partir dos resultados obtidos por Pizarro \& Carvalho (1992), onde em dois experimentos, numa mesma condição climática, havia um genótipo em comum (Paspalum atratum BRA-009610). No solo classificado como glei pouco húmico a produção para o período de máxima precipitação pluvial foi de $26 \mathrm{Mg} \mathrm{ha}^{-1}$ de $\mathrm{MS}$, enquanto que no latossolo vermelho escuro foi de $18 \mathrm{Mg} \mathrm{ha}^{-1}$ de MS. Nas duas situações o genótipo situouse entre os mais produtivos, o que é desejável visando maior amplitude de utilização.

\subsubsection{Clima}

As variações nas condições climáticas ao longo do ano promovem diferenças na quantidade e qualidade da forragem entre e dentro das estações (Evans, 1982). Uma vez que o clima não é passivel de modificações, a compreensão da relação entre seus elementos e o crescimento das pastagens possibilita a adequação de práticas de manejo ou a identificação de espécies mais adequadas em sua morfofisiologia às condições climáticas de um dado ambiente para a produção de forragem (Pinto \& Sá, 1989).

A produção de forragem resulta da conversão da radiação solar em biomassa. Por conseqüência, as variações estacionais deste componente climático afetam o crescimento das espécies forrageiras. Porém, outros componentes como o déficit hídrico e as baixas temperaturas podem limitar a utilização da radiação solar (Cooper \& Tainton, 1968).

As restrições climáticas ao crescimento das plantas variam entre as regiōes em função do grau de influência da radiação, temperatura e precipitação pluvial. Nas regiões tropicais a situação predominante é a restrição ao crescimento devido à ausência de chuvas, sendo que para as maiores latitudes, 
- abaixamento na temperatura supera o efeito do déficit hídrico (Cooper \& Tainton, 1968; Ghelfi Filho, 1972; Pinto \& Sá, 1989).

Dentro da estação de crescimento das forrageiras tropicais também são observadas variações nas condições climáticas, sendo que nas regiōes de clima tropical chuvoso a taxa de acúmulo da matéria seca alcança o máximo valor ao final da primavera ou em meados do verão, passando a diminuir no outono, quando a temperatura e a umidade no solo também diminuem (Pedreira, 1972; Rocha, 1991). Esse comportamento torna-se mais relevante nos sistemas de exploração que demandam altas produtividades, cuja abordagem tem sido baseada na seleção de genótipos com melhores ajustes a estas condições, no zoneamento ecológico e no manejo da pastagem (Corsi, 1986; Alcântara et al., 1993; Rodrigues et al., 1993).

\subsubsection{Luminosidade}

A energia necessária para a fotossíntese é proveniente da radiação solar, fotossinteticamente ativa, cuja incidência é maior nas regiões tropicais, em relação às demais, que juntamente com a maior eficiência fotossintética das gramíneas tropicais, potencialmente permitem elevadas produtividades de forragem (Cooper \& Tainton, 1968; Cooper, 1970). As variações diárias na intensidade e na disponibilidade da energia incidente são menores nos trópicos, todavia nessa região é registrada a maior amplitude entre as estações do ano, porém com caráter secundário na definição da estacionalidade da produção em relação às limitações impostas pelo regime hídrico, nutrientes e temperatura (Ghelfi Filho, 1972; Pinto \& Sá, 1989).

Num determinado ambiente 0 componente genético das espécies forrageiras responde pelos limites na taxa de fotossíntese, saturação luminosa e habilidade em interceptar a luz através da arquitetura da planta (tamanho, forma, posição e estrutura do aparato fotossintético) a qual é manejada visando maior eficiência fotossintética (Ludlow, 1978; Rodrigues et al., 1993). 


\subsubsection{Disponibilidade hídrica}

A disponibilidade hídrica é o reflexo da pluviometria e das relações no sistema solo-planta-atmosfera. Segundo Cooper \& Tainton (1968), nas regiões tropicais e subtropicais a disponibilidade de água e outros nutrientes seriam mais limitantes ao crescimento do que a luz e a temperatura, por conta da evapotranspiração ser mais elevada nestas regiões.

Embora seja limitante, a disponibilidade hídrica parece não ser o principal limitante em regiões de maior latitude. Para o capim-elefante (Pennisetum purpureum), espécie em que a irrigação seria mais factível pelas menores áreas envolvidas e face a sua produtividade, Ghelfi Filho (1972) verificou que a irrigação ao longo do ano aumentou em $24 \%$ (equivalendo a $5,8 \mathrm{Mg} \mathrm{ha}^{-1}$ de MS) a produção anual de forragem, porém quando considerada apenas a irrigação durante 0 inverno, o aumento na produção anual foi de apenas $6 \%$ (equivalendo a $1,2 \mathrm{Mg} \mathrm{ha}^{-1}$ ) em relação à ausência de irrigação. Apesar da elevação relativa na produção de inverno (26\%), a participação do crescimento do inverno no total anual passou de $24 \%$, sem irrigação, para $28 \%$ com irrigação. Neste caso, a temperatura representou a maior limitação ao crescimento, demonstrando a difícil intervenção sobre a estacionalidade da produção, e que maiores produtividades de forragem passam pelo melhor aproveitamento das condições climáticas favoráveis da primavera-verão.

De acordo com Skerman \& Riveros (1992) e Alcântara et al. (1993), Panicum maximum Jacq. não tolera secas intensas e nem inundaçōes, mostrando-se melhor adaptado a regiões com precipitações pluviais superiores a $1.000 \mathrm{~mm}$ ano $^{-1}$, enquanto que Panicum maximum var. trichoglume desenvolve-se na Austrália numa faixa de 650-1.780 mm ano-1, mas apresenta fraco desenvolvimento para médias superiores a $2.000 \mathrm{~mm}^{2} \mathrm{ano}^{-1}$. Por sua vez, Paspalum coryphaeum Trin., pelos relatos dos locais de ocorrência e de avaliações efetuadas, tolera encharcamento e persiste em locais com período seco superior a quatro meses (Araújo, 1971; Costa et al., 1988). 
Considerando-se o microclima de uma pastagem, tem-se que o déficit hídrico afeta a expansão foliar antes mesmo que os estômatos sejam fechados para a redução das perdas de água e que o processo de divisão celular seja afetado. Deste modo, dependendo da extensão do déficit hidrico, são amenizados seus efeitos sobre o crescimento vegetal (Sutcliffe, 1980; Rodrigues \& Rodrigues, 1987; Robson et al., 1989).

\subsubsection{Temperatura}

A temperatura apresenta variações estacionais e diárias, afetando principaimente os processos fisiológicos relativos ao crescimento, sendo de grance influência na distribuição e diversidade das plantas, bem como na estacionalidade da produção de forragem nas regiões de maior latitude (Rocna, 1991).

Para Cooper \& Tainton (1968) o aporte de energia é o principal fator limitando a expressão do potencial de produção das plantas, porém baixas temperaturas podem ser limitantes. Para estes autores, como geralmente as baixas temperaturas estão associadas à redução na radiação, seus efeitos sobre a produção seriam menos importantes do que o estresse hídrico nas regiões tropicais e subtropicais.

$\mathrm{Na}$ faixa tropical de maior latitude também existe ao longo do ano um mesmo padrão de flutuação da temperatura e da precipitação pluvial, sendo que baixas temperaturas estão associadas à ausência de chuvas. Neste contexto, tem-se 0 efeito combinado da baixa temperatura e do déficit hidrico sobre a estacionalidade da produção. Todavia, o trabalho de Ghelfi Filho (1972), permitiu, a partir da utilização de irrigação numa forrageira tropical no inverno, definir que a temperatura era o principal elemento do clima que limitava o crescimento no período do inverno agrostológico, pois o ganho em produtividade foi de apenas $6 \%$ para o total anual. Evidências do efeito da temperatura como o maior limitante do crescimento no inverno em forrageiras tropicais também 
foram obtidas no trabalho de Soto (1981) ao modelar o crescimento de Panicum maximum e Digitaria pentzii Stent. através de variáveis climáticas a partir dos resultados de produção de forragem obtidos por Pedreira (1972). No periodo do inverno o fator de ajuste para a umidade no solo era de menor expressão, ao contrário do período da primavera-verão, onde a irrigação poderia até elevar a taxa de crescimento da pastagem.

Nas gramíneas tropicais o maior crescimento ocorre em temperaturas entre 30 e $35^{\circ} \mathrm{C}$ e praticamente cessa em temperaturas abaixo de $15^{\circ} \mathrm{C}$, sendo estes valores superiores ao ótimo e ao crítico, respectivamente, para o crescimento das gramíneas de clima temperado (Cooper \& Tainton, 1968; Rocha, 1991). Nas condições climáticas do Estado de São Paulo Alcântara et al. (1993) previram que para 32 forrageiras o crescimento era praticamente nulo nos locais onde a temperatura mínima do ar registrada durante o mês mais frio era menor que $10^{\circ} \mathrm{C}$, o que equivalia, para as regiões consideradas, à média mensal da temperatura média do ar de $16^{\circ} \mathrm{C}$.

Em Panicum maximum e Panicum maximum var. trichoglume, as temperaturas ótimas para 0 crescimento situam-se entre $19-23^{\circ} \mathrm{C}$ e $30^{\circ} \mathrm{C}$, respectivamente, porém são sensíveis à geada. podendo se recuperarem após as mesmas (Skerman \& Riveros. 1992).

Face à ampla distribuição na região tropical e subtropical do Brasil, em Paspalum spp. também devem existir diferenças na resposta entre e dentro das espécies (Araújo, 1971; Lima \& Gondim, 1982: Allem \& Valls, 1987). Paspalum notatum cultivar Pensacola teve sua expansão pelas regiões subtropicais pela tolerância às baixas temperaturas observadas nestas regiões. Martínez et al. (1985) reportaram diferenças entre e dentro de Paspalum spp. na tolerância à geada. Paspalum plicatulum apresentou apenas $6 \%$ de folhas mortas após a geada, enquanto Paspalum commersonii foi descrito como bastante sensível.

Considerando o efeito direto sobre a planta forrageira, tem-se que a região do meristema apical é o sítio onde a temperatura se manifesta, afetando - aparecimento das folhas e perfilhos, e consequentemente o crescimento 
(Langer, 1974). Deste modo, ao início da estação de crescimento, a temperatura em elevação permite 0 acúmulo de forragem em taxas crescentes, que experimentarão redução com o sombreamento ou após o solstício de verão (Pedreira, 1972; Rocha, 1991).

A temperatura ainda pode interagir com o comprimento do dia, afetando o tempo entre o estímulo ao florescimento e a emergência das inflorescências, que é diminuido em temperaturas mais altas, pois é favorecida a elongação do colmo (Langer, 1974).

A temperatura mantem relação com a radiação que chega à superfície dos cultivos, bem como com outras variáveis climáticas. A partir desta relação e da diversidade de processos fisiológicos ligados ao crescimento e desenvolvimento das plantas em que a temperatura interfere, bem como a maior praticidade de seu registro. a mesma vem sendo adotada em estimativas da duração de estádios fenológicos, do intervalo médio entre o aparecimento de folhas (filocron), da partição da matéria seca e da elevação do meristema apical para fins de manejo ou na modelagem do crescimento das espécies (Sanderson \& Wolf. 1995: Frank \& Hofiman, 1989; George et al., 1989).

2.2.3.4. Estacionalidade da produção de forragem em Panicum maximum e em Paspalum spp.

A ação combinada das variações ao longo do ano nos principais elementos climáticos reflete-se na estacionalidade da produção de forragem, mas interagindo com o genótipo e o manejo.

Pedreira (1972), adotando metodologia especifica para estimativa da estacionalidade, observou em cinco anos de avaliação que a participação do crescimento do outono-inverno na produção anual variou de 7,7 a $24,9 \%$, para - Panicum maximum cultivar Colonião. A ampla variação sugere que a metodologia adotada foi bastante sensível para as variações entre anos.

Avaliando níveis de nitrogênio ( 0 a $225 \mathrm{~kg} \mathrm{ha}^{-1}$ ) ou a presença de leguminosas em pastagens de Panicum maximum cultivar Colonião, Mattos \& 
Werner (1979) registraram participação do crescimento de "inverno" variando de 10 a $26 \%$ para os níveis de adubação fracionados na estação de crescimento (2/3 aplicados no final das águas).

Ghisi et al. (1989) avaliaram o efeito da adubação e de genótipos de Panicum maximum, sendo a adubação nitrogenada de manutenção aplicada ao final da estação de crescimento. Para dois anos de avaliação, a adubação elevou a produção no período do "verão" e do "inverno", com o total produzido no "inverno" representando de 26 a $37 \%$ do total anual. O cultivar Aruana apresentou a menor estacionalidade na produção (37\%), enquanto que para o cultivar $\mid Z-1$ foi mais acentuada (27\%), considerando o manejo de adubação adotado.

Andrade et al. (1991) também avaliaram a resposta de cultivares de Panicum maximum a niveis de nitrogênio ( 80 e $240 \mathrm{~kg} \mathrm{ha}^{-1}$ ) fracionados igualmente em sete cortes por ano. A maior dose de nitrogênio elevou a produção de forragem, mas acentuou a estacionalidade de sua produção ( $24 \%$ do total anual no outono-inverno) em relação à menor dose (27\% do total anual). Também houve diferenças entre os genótipos, com o cultivar IZ-1 apresentando. em média, $24,4 \%$ da produção anual de forragem no período do outono-inverno.

Considerando apenas a fração folhas numa coleção com 401 acessos de Panicum maximum existente em Campo Grande-MS, Jank (1994) relatou ampla variabilidade na distribuição da produção ( 3 a $46 \%$ o total) no período de menor crescimento. Esta mesma autora também relatou resultados de dois anos com seis genótipos, sendo cinco cultivares, em seis localidades do Brasil. Verificou que no total produzido anualmente, era alta a participação do crescimento de "verão" para a forragem (71-78 \%) e para a fração folhas verdes (67-74 \%). Como havia cinco cultivares lançados mais recentemente, pode-se inferir que em geral os genótipos mais produtivos também apresentam alta estacionalidade na produção. 
Em Ariquemes-RO (4 meses de seca; pluviometria $>2.000 \mathrm{~mm} a \mathrm{ano}^{-1}$ ), Costa et al. (1988) verificaram que os dois genótipos de Paspalum spp. com maior produção anual $\left(7,6\right.$ e $8,2 \mathrm{Mg}$ ha $^{-1}$ de MS ) em cinco cortes, apresentaram 63-68 \% da produção anual no período de máxima precipitação pluvial, enquanto que na Brachiaria brizantha cultivar Marandu representou $69 \%$. Em Porto Velho-RO, Costa et al. (1989a) registraram para os mesmos genótipos (Paspalum guenoarum FCAP-43; Paspalum coryphaeum FCAP-08 e cultivar Marandu), em seis cortes anuais, cerca de 60-62 \% do total produzido anualmente ocorrendo no período de máxima precipitação pluvial.

Batista \& Godoy (1992b), ao avaliarem 46 genótipos de Paspalum spp. em São Carlos-SP. verificaram que em média a coleção produziu $64 \%$ do total anual ( 2 cortes nas águas e 2 cortes na seca) no período das águas. Entre os cinco genótipos com maior produção anual, o total produzido nas águas representou de 63 a $73 \%$ do total anual. Na mesma localidade, numa coleção com 102 acessos de Paspalum spp., Batista et al. (1994) obtiveram, para os sete acessos com melhor desempenho (4 cortes ano $\left.{ }^{-1}\right), 52$ a $74 \%$ da produção anual ocorrendo no período das águas, sendo que para o Paspalum coryphaeum BRA-000841, o mais produtivo com 21,4 Mg ha $\mathrm{ha}^{-1}$ de MS, representou $64 \%$ do total produzido anualmente.

Pizarro \& Carvalho (1992) obtiveram num solo glei pouco húmico pequena participação do crescimento do período de mínima precipitação pluvial na produção anual de Paspalum spp. Para os três genótipos com maior produção anual, o crescimento na estação seca representou de 7,5 a 8,8 \% do total anual. Em parte os baixos valores decorreram do esquema de avaliação na estação chuvosa, pois o intervalo entre cortes foi longo para a duração do período, o que favoreceu a produção nessa época do ano. 


\subsubsection{Manejo}

Por manejo considera-se o conjunto de práticas viáveis de aplicação nos componentes do ecossistema de uma pastagem, a partir do conhecimento das interrelações existentes, visando maximizar elou manter a produtividade da planta forrageira e dos animais que dela se alimentam.

A abrangência e o grau de intervenção das práticas de manejo estão relacionadas com as limitações existentes no ambiente das pastagens, com a produtividade a ser alcançada e com o sistema de produção em que a pastagem está inserida. Desta forma, nos sistemas intensivos de produção, estas práticas tornam-se mais freqüentes visando atender a maior demanda existente para a produção.

As práticas de manejo estão ligadas aos componentes solo, planta e animal, mas procuram integrar as relações existentes entre os mesmos e as condições climáticas locais.

\subsubsection{No componente solo}

No solo as práticas de manejo visam modificar a sua fertilidade (lato senso) para adequá-la às exigências da planta forrageira em crescimento.

Nos atributos físicos, face a extensão das áreas com pastagens, a intervenção é mínima, sendo que as limitações existentes, em geral, são abordadas através da escolha de genótipos mais adaptados às condições vigentes.

A pressão exercida sobre o solo pelos animais em pastejo é elevada e contínua, podendo ocasionar compactação do solo em pastagens pouco produtivas e superpastejadas. Todavia $o$ aporte e a ciclagem de nutrientes pelo sistema radicular, a cobertura do solo proporcionada e a distribuição do sistema radicular, tem-se que a exploração do solo com pastagens produtivas seria mais conservacionista do que a exploração com cultivos anuais (Cerri, 1989; 
Lombardi Neto, 1993). A compactação e a erosão não deverão ser problemas em áreas cultivadas com pastagens. desde que produtivas, e para tanto 0 componente químico da fertilidade do solo deve ser considerado.

Os solos tropicais, em geral, apresentam restrições de natureza química para o estabelecimento e manutenção da produtividade das pastagens. A exportação de nutrientes como produto animal e as perdas por lixiviação e imobilização reduzem a disponibilidade de nutrientes minerais para 0 crescimento das plantas. A não aplicação, mesmo que em níveis mínimos, de nutrientes para assegurar o adequado estabelecimento ou a manutenção da produtividade da planta forrageira, tem sido apontada como a principal causa da degradação das pastagens (Zimmer et al. 1994).

Qualquer nutriente poderá limitar a produtividade das pastagens, porém os macronutrientes, por conta da maior demanda e exportação pelas plantas, e pelos teores originalmente baixos nos solos, têm merecido maior atenção. Para as gramíneas sobressaem-se o manejo do fósforo e do nitrogênio por serem mais limitantes ao estabelecimento, perfilhamento e manutenção dos patamares de produtividade (Werner, 1986a). Nos sistemas mais intensivos, o potássio também reveste-se da importância, embora sua reciclagem seja alta com o pastejo (Monteiro \& Werner, 1989). Por sua vez, os micronutrientes apresentam maior expressão nos sistemas que incluem leguminosas, mas poderão ocorrer deficiências em pastagens com gramíneas cuja intensificação da exploração dáse através de elevada saturação por bases visando potencializar adubações com macronutrientes (Mattos \& Colozza, 1986).

O principal objetivo da adubação é elevar a produção de forragem, porém a maior disponibilidade de nutrientes e o ritmo de crescimento das planta adubadas poderão modificar os teores dos componentes químicos, que em associação com as modificações decorrentes da idade e proporção das frações passam a ser relevantes para a eficiência no aproveitamento da forragem pelos animais (Hacker \& Minson, 1981; Corsi \& Silva, 1985), 
A resposta das plantas forrageiras à prática da adubação tem diferido em magnitude em função da espécie forrageira, do clima, níveis de adubação $e$ manejo da planta (Martinez, 1980; Cook \& Mulder, 1984a; Werner, 1986). Gramineas com maior potencial para a produção de forragem, como o Panicum maximum, em geral apresentam maior demanda pelos nutrientes minerais, sendo sensiveis ao manejo da fertilidade do solo, desde o estabelecimento.

A adubação nitrogenada, não havendo outras limitações, promove as maiores respostas em produtividade nas pastagens, sendo a espécie Panicum maximum uma das mais responsivas à aplicação deste nutriente. No trópico úmido de Porto Rico, Panicum maximum apresentou resposta à aplicação de até $1,8 \mathrm{Mg} \mathrm{ha}^{-1}$ de $\mathrm{N}$, com produções variando de 30 a $54 \mathrm{Mg} \mathrm{ha}^{-1}$ de $\mathrm{MS}$, com respostas praticamente lineares à aplicação de $450 \mathrm{~kg}^{-1}$ de $\mathrm{N}$ (VicenteChandler et al.,1959). Tem-se explorado a faixa de resposta linear de produção de forragem. mas predominantemente não se utilizam doses de nitrogênio próximas do limite superior desta faixa.

Gomide (1994) compilou experimentos com respostas lineares à aplicação de $\mathrm{N}$ em Panicum maximum cultivar Colonião. A resposta à adubação variou de 7 a 32 quilogramas de matéria seca produzidas para cada quilograma de nitrogênio aplicado, indicando que vários fatores devem estar envolvidos na eficiência do uso do nutriente.

Em geral, para o nitrogènio aplicado a eficiência de recuperação é menor quando os intervalos entre desfolhas é reduzido ou quando elevam-se as doses aplicadas, o que também concorre para uma maior demanda deste nutriente nos sistemas mais intensivos de produção. Em Queensland, Austrália, a resposta a niveis de adubação nitrogenada (25-50-100 kg ha-1 de N), aplicados após cada corte. foi avaliada em 10 gramíneas tropicais, entre elas Panicum maximum cultivar Makueni e Paspalum plicatulum cultivar Bryan. No período de máxima produção, a cada quatro semanas o cultivar Makueni produziu, em média, 4,1 $\mathrm{Mg} \mathrm{ha}^{-1}$ corte $^{-1}$ de MS, enquanto o cultivar Bryan produziu 3,6 $\mathrm{Mg} \mathrm{ha}^{-1}$ corte $^{-1}$ de MS, quando aplicados $25 \mathrm{~kg} \mathrm{ha}^{-1}$ corte $^{-1}$ de N. O incremento na produção de MS 
foi em menor escala para as maiores doses. Para a faixa entre 25 e $50 \mathrm{~kg} \mathrm{ha}^{-1}$ de $\mathrm{N}$ corte $^{-1}$, os incrementos na produção foram de 33,7 (cultivar Makueni) e $39,8 \mathrm{~kg}$ de MS por $\mathrm{kg}$ de $\mathrm{N}$ (cultivar Bryan), enquanto que para o intervalo entre 50 e $100 \mathrm{~kg} \mathrm{ha}^{-1}$ corte $^{-1}$ de $\mathrm{N}$ foi de 28,6 (cultivar Makueni) e $21,0 \mathrm{~kg}$ de MS por $\mathrm{kg}$ de $\mathrm{N}$ (cultivar Bryan) (Cook \& Mulder, 1984a). Verificou-se a grande capacidade de resposta dos cultivares à adubação nitrogenada fracionada, favorecida pelas condições ambientais.

Existem diferenças marcantes na resposta à adubação dentro de uma espécie. GHISI et al. (1989) num solo podzólico vermelho amarelo $(\mathrm{pH}=5,1$; $P=6,3 \mathrm{mg} \mathrm{dm}^{-3}$ ), com aplicações anuais ao final das águas equivalentes a $50 \mathrm{~kg}$ ha ${ }^{-1}$ de $\mathrm{N}, 103 \mathrm{~kg} \mathrm{ha}^{-1}$ de $\mathrm{P}$ e $2 \%$ da produção de MS como K, obtiveram produções anuais de 27,2 e $21 \mathrm{Mg} \mathrm{ha}^{-1}$ de $\mathrm{MS}$, para o Panicum maximum cultivar IZ-1 e Aruana, respectivamente.

Num latossolo vermelho amarelo $\left(\mathrm{pH}=4,7\right.$ e $\mathrm{P}=4,1 \mathrm{mg} \mathrm{dm} \mathrm{m}^{-3}$ ) Andrade et al. (1991) aplicaram o equivalente a 80 e $240 \mathrm{~kg} \mathrm{ha}^{-1}$ de $\mathrm{N}$ fracionados em sete cortes ao longo do ano em três cultivares de Panicum maximum. Houve resposta aos níveis de adubação nitrogenada, mas não havendo diferenças entre o cultivar IZ-1 e o cultivar Tobiatã, com a produção anual alcançando em dois anos $8.0\left(80 \mathrm{~kg} \mathrm{ha}^{-1} \mathrm{~N}\right)$ e $13,1 \mathrm{Mg} \mathrm{ha}^{-1}$ de $\mathrm{MS}\left(240 \mathrm{~kg} \mathrm{ha}^{-1} \mathrm{~N}\right)$, sendo que $72.6\left(80 \mathrm{~kg} \mathrm{ha}^{-1} \mathrm{~N}\right)$ e $75,8 \%\left(240 \mathrm{~kg} \mathrm{ha}^{-1} \mathrm{~N}\right)$ do crescimento ocorrendo no período das águas.

Embora as quantidades extraídas pelas plantas sejam menores do que as de nitrogênio e potássio, o fósforo tem sido o nutriente mais utilizado em adubações, por conta da baixa disponibilidade nos solos tropicais e da natureza das interações deste elemento no solo (Raij, 1991).

O fósforo é apontado como o nutriente mais importante na fase de estabelecimento da pastagem, enquanto que após esta fase, o nitrogênio apresenta maior impacto na produtividade, embora o fósforo também se faça necessário para assegurar manutenção da produtividade (Werner, 1986a). 
Paulino et al. (1990) avaliaram gramíneas submetidas ou não à adubação de manutenção (450 kg ha-1 de superfosfato simples, $390 \mathrm{~kg} \mathrm{ha}^{-1}$ de cloreto de potássio e $150 \mathrm{~kg} \mathrm{ha}^{-1}$ de $\mathrm{N}$ ) num latossolo roxo $\left(\mathrm{pH}=5,1 ; \mathrm{P}=1 \mathrm{mg} \mathrm{dm}^{-3}\right.$ ). No primeiro ano as produçōes foram elevadas sendo que o cultivar Aruana produziu $23,5 \mathrm{Mg} \mathrm{ha}^{-1}$ de MS nas parcelas adubadas, equivalendo a $57 \%$ de aumento em produção em relação às parcelas apenas com adubação de plantio. No segundo ano as produções, em média, foram menores $\left(17,8 \mathrm{Mg} \mathrm{ha}^{-1}\right.$ de $\left.\mathrm{MS}\right)$, porém 137 \% superior ao tratamento sem adubação de manutenção. Entre anos, por sua vez, a redução na produção de forragem no segundo ano foi de $75 \%$ nas parcelas adubadas do cultivar Aruana, e de $50 \%$ nas parcelas não adubadas, sendo o cultivar que experimentou maior redução na produção entre as gramineas avaliadas.

Normalmente, nas áreas cultivadas com pastagens, o potássio não constitui a maior limitação à produção de forragem, pela disponibilidade no solo e pela reciclagem através da urina e fezes dos animais (Werner, 1986b). Porém, se considerados os teores de potássio nas plantas forrageiras e dependendo do sistema de aproveitamento das mesmas, a quantidade de nutriente a ser reposta pode superar até mesmo a de nitrogênio. Se manejadas para corte, ou com pastejo rotacionado com periodo de ocupação reduzido, ou com elevadas doses de nitrogênio. o potássio com o tempo passará a limitar a produtividade, devendo ser suprido.

Existem diferenças quanto as exigências e resposta das plantas forrageiras à pratica de adubação (Andrew \& Robins, 1971; Martinez, 1980). A planta mais adequada para fins de manejo da adubação deverá apresentar flexibilidade na resposta a niveis de adubação, ou seja, capaz de mostrar-se eficiente na absorção e na utilização dos nutrientes minerais, o que permitiria elevar a produtividade sem a substituição do genótipo explorado ou ajustar a oferta de forragem ao longo da estação de crescimento com a adubação, especialmente nitrogenada. Panicum maximum mostra-se mais eficiente na 
utilização do que na absorção dos nutrientes minerais em relação a outras espécies (Martinez, 1980).

A resposta à adubação e outras práticas de manejo em Paspalum spp. foi investigada principalmente nos cultivares selecionados ou melhorados para as condições subtropicais. Além disso não apresentam hábito de crescimento cespitoso, ao contrário dos tipos predominantes nas coleções em avaliação nas condições tropicais. Desta forma, além da escassez de informações sobre o gênero, em boa parte não permitem maiores inferências.

Carvalho et al. (1992) avaliaram 42 genótipos de Paspalum spp. num latossolo vermelho escuro adotando dois padrões de correção e adubação para a formação de pastagens, sendo que num deles equivalia à correção e adubação para cultivos anuais daquela região, porém sem adubação nitrogenada. Nas avaliações para produção de forragem, efetuadas na fase de estabelecimento e ao final do primeiro ano, não constataram o efeito dos padrões de adubação de estabelecimento. Possivelmente a ausência de adubação nitrogenada tenha sido responsável pela ausência do efeito da aplicação do corretivo e demais nutrientes.

\subsubsection{No componente planta}

As práticas de manejo ligadas diretamente à planta buscam maximizar a eficiência da mesma na conversão da energia solar e aproveitamento dos nutrientes do solo a partir dos conhecimentos da morfofisiologia da espécie explorada objetivando rebrotas rápidas e vigorosas ao longo das estações.

Em geral. o padrão de acúmulo no tempo da matéria seca da parte aérea das plantas forrageiras pode ser descrito por uma curva do tipo sigmóide, onde o acúmulo de forragem ocorre inicialmente com baixas taxas, mas crescentes, que atingem o seu máximo valor, para em seguida sofrerem uma inflexão, passando a decrescer, até cessar o acúmulo de forragem (produção teto). 0 que se busca é atingir mais rapidamente a fase em que as plantas apresentam 
maior taxa de crescimento (Hunt,1982; Corsi, 1986; Rodrigues \& Rodrigues, 1987).

A desfolha nas plantas forrageiras deve estar fundamentada em bases fisiológicas e, para tanto, três aspectos devem ser considerados na avaliação de seus efeitos sobre as plantas forrageiras: a freqüência, a intensidade e o momento em que são efetuadas. $O$ aspecto intensidade é o mais abrangente pois envolve a severidade, duração, altura e porcentagem de utilização (Harris, 1978). Nestes três aspectos estão contemplados os principais mecanismos que procuram assegurar a máxima expressão do potencial genético da planta forrageira num dado ambiente.

A resposta mais comum à desfolha é que dado um estádio de desenvolvimento, quanto maior a freqüência ou maior a intensidade, serão observados decréscimos na produção no tempo.

As reservas orgânicas, o conceito de índice de área foliar (IAF) e a sobrevivência dos meristemas apicais têm sido os principais parâmetros responsabilizados pelas diferenças entre as combinações da freqüência, intensidade e momento das desfolhas.

\subsection{Reservas orgânicas}

O envolvimento das reservas orgânicas na rebrota foi sugerido após a redução dos niveis de carboidratos de reserva na plantas com a desfolha, passando-se a pressupor uma grande dependência dos mesmos no processo de rebrota. Vários trabalhos mostraram esta relação de dependência para os carboidratos não estruturais, mas também a existência de outras substâncias envolvidas, daí porque ampliou-se o conceito para reservas orgânicas (Sheard, 1973; Vickery, 1981). Admite-se que as reservas orgânicas são usadas para a rebrota, mas por um curto espaço de tempo ( 2 a 7 dias em gramíneas), após o que passam a prevalecer a área foliar e a fotossíntese (Harris, 1978; Vickery, 1981; Blaser, 1990) 
Os niveis das reservas orgânicas tendem a ser menores em plantas com crescimento intensivo ou quando submetidas a altas doses de adubações nitrogenadas. Por sua vez, o acúmulo de reservas dá-se quando a taxa de crescimento é menor, sendo os principais locais de acúmulo as raízes e a base do caule, para as gramíneas (Sheard, 1973). Por sua vez, o tempo necessário para que as reservas orgânicas atinjam os niveis originais após a desfolha depende do ritmo de crescimento, sendo que para altas taxas de crescimento geralmente as reservas tendem a permanecer em niveis mais baixos por mais tempo. Também, uma vez utilizadas as reservas orgânicas, o tempo necessário para a reposição das mesmas mantem uma relação inversa com a severidade das desfolhas (Vickery, 1981).

Gomide \& Zago (1980) tentaram associar os níveis de carboidratos não estruturais (CNE) na base do caule do Panicum maximum cultivar Colonião em várias idades (2 a 63 dias) e em períodos de crescimento da estação chuvosa com a rebrota após corte a uma altura de $15 \mathrm{~cm}$ do solo. Os níveis dos CNE reduziram-se após a desfolha e mantiveram-se baixos até sete dias após a desfolha, porém após 14 e 21 dias os níveis já estavam restabelecidos. Neste caso, foram obtidas baixas correlações entre CNE e a rebrota, com os autores inferindo que outros fatores seriam mais determinantes no vigor da rebrota, não descartando porém o envolvimento das reservas na formação das primeiras folhas.

Gomide et al. (1979) verificaram que os teores de CNE na base do caule mantiveram relação inversa com a altura do corte $(15$ ou $25 \mathrm{~cm}$ ) em plantas de Panicum maximum cultivar Colonião.

De certo modo, as reservas orgânicas são responsáveis pela redução do periodo entre o início da rebrota e a máxima taxa de, sendo que a influência das mesmas no prolongamento deste período será maior quando o intervalo entre as desfolhas for menor. 


\subsection{Indice de área foliar}

Uma vez que as folhas são as principais estruturas fotossintéticas, criouse 0 conceito de índice de área foliar (IAF), como indicativo da capacidade fotossintética de uma comunidade vegetal.

O manejo baseado no conceito do índice de área foliar (IAF) está bem fundamentado do ponto de vista físiológico, pois o crescimento é o reflexo do balanço entre fotossintese e respiração. Deste modo, a desfolha total das plantas não é desejável pois, a fotossíntese seria bruscamente interrompida, afetando as taxas de rebrota (Ludlow, 1978; Vickery, 1981).

Em pastagens em crescimento livre a evolução do IAF explica as alterações na taxa de crescimento decorrentes das mudanças no aparato fotossintético. A situação desejável do ponto de vista produtivo representa o conceito de IAF ótimo, que seria o limite superior da faixa de resposta linear crescente da curva de crescimento de uma pastagem, onde seria máxima a relação entre a fotossíntese e a respiração, com as folhas inferiores do dossel estando acima do ponto de compensação. Todavia, segundo Vickery (1981), o IAF ótimo é difícil de ser alcançado e mantido, em parte por ser dinâmico. Em cultivos anuais o conceito tem variação estacional, e a combinação dos componentes do ambiente podem deslocar o IAF ótimo para niveis não compatíveis com a estrutura da comunidade vegetal. Esta situação pode ocorrer em regiões com alta incidência de radiação que superaria a capacidade de interceptação da planta. Além disso, o IAF ótimo varia entre as espécies algumas delas não apresentam saturação luminosa.

Considerando-se o microclima da pastagem, Skerman \& Riveros (1992) e Rodrigues et al. (1993) descreveram que Panicum maximum apresenta média tolerância ao sombreamento e Paspalum conjugatum alta tolerância ao sombreamento. 


\subsection{Meristemas apicais}

A exploração de rebrotas vigorosas a partir da relação entre eliminação dos meristemas apicais tem sido bastante estudada em forrageiras tropicais, ao contrário dos demais critérios já apresentados. Assim como nos demais critérios, busca-se a rápida reposição das folhas, encurtando o periodo entre a desfolha e aquele com a máxima taxa de crescimento da planta forrageira, proporcionada pela dominância apical que induz o fluxo preferencial de nutrientes para as zonas meristemáticas. O tempo necessário para a elongação de uma folha consumida parcialmente, ou para o aparecimento de uma nova folha a partir do meristema apical ativo, é bem menor do que o tempo necessário entre a detecção da quebra da dominância apical e o crescimento das gemas axilares ou basilares (Langer, 1974).

Neste princípio de manejo da planta forrageira passa a ser relevante a posição do meristema apical e a sua taxa de elevação, que até certo ponto mantem relação com a altura da planta quando na fase reprodutiva, o que confere maior aplicabilidade prática deste princípio.

Alcântara et al. (1985) estudaram o crescimento de seis cultivares de Panicum maximum estabelecidos no espaçamento de $0,5 \mathrm{~m}$ entre linhas, quando submetidos a níveis de adubação $\left(N_{1}=10 \mathrm{~g} \mathrm{~m}^{-2}\right.$ superfosfato simples(SS) $+5.5 \mathrm{~g} \mathrm{~m}^{-2}$ Uréia (U); $\mathrm{N}_{2}=40 \mathrm{~g} \mathrm{~m}^{-2} \mathrm{SS}+5,5 \mathrm{~g} \mathrm{~m}^{-2} \mathrm{U} ; \mathrm{N}_{3}=40 \mathrm{~g} \mathrm{~m}^{-2} \mathrm{SS}+11,1$ $\left.\mathrm{g} \mathrm{m}^{-2} \mathrm{U}\right)$. As avaliações mensais cobriram um período de 12 meses, a partir da uniformização efetuada no mês de julho. Os autores não observaram efeito da adubação sobre a altura do meristema apical, ao considerarem as médias das observações ao longo do período de avaliação. Todavia, houve efeito de cultivar, sendo que para os seis cultivares a altura do meristema apical variou de 8,7 a $19,5 \mathrm{~cm}$ do solo. O cultivar $\mathrm{IZ}-1$ apresentou as menores médias $(9,9$ a 11 $\mathrm{cm})$, enquanto que o cultivar Aruana teve as maiores médias (16,6 a 19,5 cm). O cultivar Aruana, com cerca de 30, 60 e 90 dias após o corte em julho, apresentou altura média do meristema apical de 47,6; 110,8 e 111,7 cm, respectivamente, enquanto que o cultivar $I Z-1$ apresentava seus meristemas a 
56,$4 ; \quad 36,5$ e $26,4 \mathrm{~cm}$ do solo, com aproximadamente 30,60 e 90 dias, respectivamente, após o corte efetuado em julho. Os valores decrescentes para - cultivar IZ-1 não são óbvios e devem decorrer da variabilidade na amostragem, uma vez que as medidas foram tomadas em três perfilhos por parcela. Considerando a posição média do meristema apical ao longo do período, as autoras identificaram o cultivar $\mid Z-1$ como de manejo mais fácil, pela maior proximidade do meristema apical do solo, recomendando o manejo para o resíduo pós-pastejo na altura de $15-20 \mathrm{~cm}$. Por sua vez, o cultivar Aruana, teria o seu manejo mais difícil, requerendo manejo mais alto, sendo sugerida a altura residual de $20-30 \mathrm{~cm}$ para que fosse evitada a eliminação do meristema apical pelo corte ou pastejo.

Andrade (1987) na comparação de três genótipos de Panicum maximum em crescimento livre a partir de setembro também avaliaram a elevação do meristema apical e a altura das plantas por 196 dias, tendo sido aplicado o equivalente a $100 \mathrm{~kg} \mathrm{ha}^{-1}$ de $\mathrm{N}, 17,4 \mathrm{~kg} \mathrm{ha}^{-1}$ de $\mathrm{P}$ e $50 \mathrm{~kg} \mathrm{ha}^{-1}$ de $\mathrm{K}$, com espaçamento entre linhas de $0,25 \mathrm{~m}$. Para o cultivar $\mathrm{ZZ}-1$ a altura das plantas, em cm, após 28, 56, 84, 112, 140, 168 e 196 dias de crescimento era de 33, 98. 130, 182, 190, 196 e $199 \mathrm{~cm}$, respectivamente, enquanto que os meristemas apicais situavam, para os mesmos intervalos de crescimento, a 1 , 2. 23. $60,77,74$ e $95 \mathrm{~cm}$ do nível do solo, respectivamente. Observa-se que a taxa de elevação do meristema apical é baixa, considerando o porte desse cultivar e a adubação efetuada. Por sua vez, a produtividade da rebrota avaliada 28 dias após o corte em cada intervalo de crescimento elevou-se até o intervalo de 84 dias (1,4 $\mathrm{Mg} \mathrm{ha}^{-1}$ de MS ), quando o meristema apical situava-se, em média, a $23 \mathrm{~cm}$ do nível do solo. Porém, a rebrota experimentou decréscimos aos 112 dias $\left(0,65 \mathrm{Mg} \mathrm{ha}^{-1}\right)$, quando o meristema apical situava-se a $60 \mathrm{~cm}$ do nivel do solo, bem acima da altura do corte $(10 \mathrm{~cm})$. Para o cultivar Tobiatã foi observada a mesma tendência para a redução do vigor da rebrota em relação ao cultivar IZ-1, enquanto que para o genótipo K-187B a rebrota foi 
uniforme $\left(0,95 \mathrm{Mg} \mathrm{ha}^{-1}\right.$ de $\left.\mathrm{MS}\right)$, visto que após 112 dias de crescimento 0 meristema apical situava-se a $34 \mathrm{~cm}$ do nivel do solo.

Gomide et al. (1979) avaliaram os efeitos da adubação e da idade da planta em períodos de crescimento sobre a eliminação do meristema apical e o vigor da rebrota ( $\mathrm{kg} \mathrm{MS} \mathrm{em} 21$ dias) numa área com Panicum maximum cultivar Colonião, em crescimento por 98 dias. A adubação de cobertura equivaleu a 25 $\mathrm{kg} \mathrm{ha}^{-1}$ de $\mathrm{N}$ e $25 \mathrm{~kg} \mathrm{ha}^{-1}$ de $\mathrm{K}$, sendo a área também submetida à irrigação, quando necessária. O meristema apical elevou-se com o tempo (14 a 98 dias) e em cada período de crescimento (dezembro a fevereiro), sendo que a adubação também estimulou a elevação mais precocemente, em relação ao tratamento sem adubação, em todos os períodos de crescimento. No crescimento que se iniciou em janeiro, o meristema apical situou-se para as parcelas sem ou com adubação aos $28,42,56$ e 98 dias a uma altura de 1 ou 1,$4 ; 3$ ou 5,$2 ; 17,5$ ou 23,$9 ; 30,2$ ou 41,$7 ; 58,4$ ou $55 ; 83,6$ ou 86,9 ; e 94,2 ou $99 \mathrm{~cm}$ do solo, respectivamente. A porcentagem de eliminação dos meristemas apicais para esse crescimento era inferior a $1 \%$ até 28 dias, mas elevou-se rapidamente, atingindo 55, 87, 96 e $100 \%$ de eliminação aos 42, 56, 70 e 84 dias de crescimento, respectivamente. Este comportamento afetou a produção de forragem na rebrota, que era de 1,6 Mg ha-1 MS em 21 dias, quando as plantas foram cortadas com até 4 semanas de idade, e inferiores a 0,54 Mg ha-1 MS em 21 dias, para as plantas com idade superior a 6 semanas. Para as mesmas idades, a rebrota tendeu a ser menos vigorosa, quando considerados periodos de crescimento posteriores (fevereiro), pois para estas épocas, por ocasião do corte de uniformização possivelmente o meristema apical já estivesse em elevação. Foram significativas as correlações lineares simples $(r>0,92)$ entre a eliminação do meristema apical e o vigor da rebrota em todos os crescimentos, nos tratamentos com e sem adubação. Não foi verificada correlação significativa entre os teores de carboidratos não estruturais e 0 vigor da rebrota, demonstrando que a rápida recuperação da planta era mais dependente da preservação dos meristemas apicais. 
De um modo geral, a freqüência e a intensidade das desfolhas são os principais parâmetros a serem combinados de forma inversa na definição do manejo das desfolhas das plantas forrageiras. Altas freqüências de desfolhas removem as folhas com maior eficiência fotossintética e não permitem ou reduzem o acúmulo das reservas orgânicas. Desfolhas intensas geram maior dependência das reservas, afetam seus níveis e reduzem o número de sítios da planta com crescimento mais ativo (Gomide, 1979; Omaliko, 1980; Middleton, 1982). Os limites para a melhor combinação dessas variáveis dependem da espécie vegetal explorada, das condições ambientais, do sistema de produção e do periodo de crescimento dentro da estação. Outro ponto a ser considerado, é que a extensão das respostas ao manejo podem ser limitadas, dependendo da plasticidade do genótipo, com adaptações na morfologia e/ou na sua fisiologia (Rodrigues \& Rodrigues, 1987; Youngner, 1972).

Estes princípios apresentados são aplicáveis para diagnóstico indireto da necessidade de ajustes no manejo, uma vez que existem dificuldades na implementação visando ajustes instantâneos no manejo. $\mathrm{Na}$ prática, as principais decisões sobre o manejo estão relacionadas com a altura da planta, que indiretamente reflete a forragem disponivel, posição do meristema apical e índice de área foliar. Todavia, a estimativa direta destes parâmetros ou de uma eventual relação dos mesmos com a altura não pode ser definida, sobretudo pela ausência de técnicas de avaliação que permitam, para as forrageiras tropicais, predominantemente cespitosas, definir em tempo hábil a condição da pastagem sem que haja perda de acuidade nas estimativas. Nas pastagens de clima temperado, pela maior uniformidade da pastagem ao longo do dossel, conceitos como o de IAF ótimo podem ser melhor explorados, pois as estimativas estão relacionadas com atributos simples de serem tomados, como a altura da pastagem.

Através das considerações sobre freqüência, intensidade e momento da desfolha, juntamente com práticas de manejo, como a da adubação, inúmeros trabalhos têm procurado definir faixas de trabalho para um melhor manejo da 
planta forrageira. Uma ampla diversidade de resultados tem sido relatada em experimentos baseados em cortes, porém os padrões ou a magnitude das respostas não são os mesmos entre locais ou quando avaliados sob pastejo.

\subsubsection{No componente animal}

Com o manejo animal pretende-se assegurar as exigências do animal para a melhor expressão da sua produção e manter a capacidade produtiva da pastagem, minimizando os efeitos da desfolha sobre a mesma, do pisoteio e da distribuição desuniforme de nutrientes pelas fezes e urinas (Holmes, 1989).

Embora os efeitos da relação animal-planta sejam mútuos. nas condições tropicais o principal fator limitante no sistema é a produção de forragem, mesmo com o potencial apresentado pelo clima e as forrageiras tropicais. Assim sendo, predominantemente, as práticas adotadas no manejo animal são inicialmente definidas pelo potencial elou restrições que a planta apresenta para a expressão da sua produção (em parte apresentadas nos tópicos solo-planta) e pela eficiência de aproveitamento da forragem produzida (Holmes, 1989; Corsi et al., 1994).

Como a planta representa o eixo central do sistema, no manejo animal os conceitos relativos aos fundamentos fisiológicos para rebrotas rápidas e vigorosas procuram ser aplicados, sendo o animal o agente da desfolha. Nos sistemas intensivos de produção busca-se minimizar as perdas por senescência durante a produção da forragem, porém mesmo com a máxima taxa de crescimento da pastagem e a menor quantidade de material senescido compondo a forragem, a produção animal nem sempre tem-se mostrado compatível, visto que os animais em pastejo apresentam baixa eficiência no aproveitamento da forragem. Deste modo, embora inicialmente as perdas de forragem pela senescência sejam pequenas, passam a se elevar pela progressiva participação do material senescido no resíduo pós-pastejo. Maiores intensidades de pastejo, mesmo em detrimento da produtividade líquida da pastagem, têm sido utilizadas visando maior eficiência no aproveitamento da 
forragem produzida pela redução das perdas de folhas por senescência (Parsons, 1988).

Buscando conciliar as exigências do animal com as da planta forrageira, sistemas de pastejo, com suas variações na intensidade e freqüência das desfolhas são propostos, aos quais são atribuidas vantagens comparativas (Maraschin, 1986; Vickery, 1981, Parsons, 1988). Numa revisão sobre sistema de pastejo, Simão Neto (1986) enumerou que na tomada de decisão acerca de um sistema devem ser consideradas a espécie forrageira, a taxa de lotação e a disponibilidade de forragem. O mesmo autor relatou outros fatores, tais como o tipo de exploração, ecossistema, taxa de retorno esperada, incentivos à produção e capacidade de investimento. No atual contexto, estes últimos fatores têm sido mais cruciais na decisão sobre o manejo animal a ser adotado, uma vez que o potencial de produção das forrageiras tropicais é elevado e essas plantas apresentam flexibilidade de uso.

\subsection{Componentes da produção de forragem em gramíneas: variações com o crescimento e o manejo}

A produtividade ou a forragem disponivel numa pastagem expressam contribuições individuais de componentes cujos processos de crescimento e desenvolvimento acarretam modificações na participação relativa dos mesmos, alterando a condição e a estrutura da pastagem.

O padrão e a extensão destas alterações sofrem grande influência das condições ambientais, e revestem-se de importância porque estão atreladas à eficiência no consumo e conversão da forragem produzida. 


\subsubsection{População de plantas}

Em pastagens estabelecidas, a densidade de plantas num dado momento é o reflexo do balanço entre a mortalidade e o surgimento de novas plantas desde o estabelecimento. Reduções na densidade de plantas ocorrem durante a fase de estabelecimento, em geral por condições climáticas adversas ou processos competitivos.

Em Brachiaria brizantha cultivar Marandu, Zimmer et al. (1994) relataram que maiores produções de forragem estiveram associadas ao maior número de plantas na fase de estabelecimento. A proporção de plantas estabelecidas foi inferior a $30 \%$, quando adotadas altas taxas de semeadura, sendo forte evidência da competição intraespecífica.

Outro aspecto a ser considerado é o arranjo e o espaçamento das plantas. Em geral os plantios são feitos em linhas, de modo a favorecer a execução de tratos culturais. O espaçamento entre linhas, em geral, é maior em área para produção de sementes cuja colheita é efetuada por varredura (Andrade, 1994).

Após o estabelecimento, a densidade de plantas pode sofrer alteraçōes, elevando-se, quando bem manejadas e havendo espaços pela adoção de baixas densidades de semeadura, ou diminuindo pelo superpastejo ou processos competitivos. Com sucessivos pastejos as plantas ajustam-se morfologicamente, modificando a arquitetura, tendendo a estabilizar o seu número na pastagem, pois processos competitivos limitam o estabelecimento de novas plantas.

Plantas mais espaçadas permitem maior incidencia de luz na base de suas touceiras, estimulando o aparecimento de perfilhos em maior número e por maior tempo do que para plantios adensados, que tendem a ser menos eretos por conta da menor competição por luz inicial (Langer, 1963; Ludlow, 1978). Na fase inicial do crescimento a pastagem apresentará menor IAF, em relação aos plantios mais adensados, o que representará menor interceptação luminosa. 
A produtividade da pastagem dependerá da influência do número e tamanho dos perfilhos por planta, compensando, até certo ponto, a densidade de plantas. Num intervalo com maiores espaçamentos, a relação tende a ser direta com o número de plantas. Para milho (Zea mays L.) cultivado para produção de forragem com densidades de plantas variando de 4,9 a 11,1 plantas $\mathrm{m}^{-2}$, a maior produtividade da cultura nas maiores densidades de plantio decorreram do maior número de plantas, apesar do menor peso das hastes (Jolliffe et al., 1990). Para forrageiras tropicais convencionais, esta relação pode ser modificada pelo perfilhamento, porém é desconhecida pois os trabalhos sobre estabelecimento de pastagens não contemplaram a análise dos componentes da produção.

São reportados vários espaçamentos de plantio para Panicum maximum. Quando estabelecido por sementes o espaçamento varia de 0,2 a 1,0 m entre linhas, e quando vegetativamente pode ser de até 1,2 $\mathrm{m}$. Para Paspalum spp. são relatados espaçamentos entre linhas de 0,2 a $0.4 \mathrm{~m}$ (Martínez et al., 1985; Skerman \& Riveros, 1992).

\subsubsection{Perfilhos}

O perfilho representa a unidade estrutural e produtiva das gramíneas forrageiras, sendo classificado, conforme a posição das gemas que thes dão origem, em basal e aéreo. O número em potencial de perfilhos na planta relaciona-se com o aparecimento das folhas, sendo que em gramíneas de clima temperado, o perfilhamento aéreo obedece a intervalos entre o aparecimento das folhas (Youngner, 1972; Langer, 1974). Deste modo, o aparecimento e o desenvolvimento dos perfilhos estão associados à atividade meristemática (Langer, 1963), que para as gramíneas tropicais e guardadas as diferenças entre genótipos, relaciona-se positivamente com altas temperaturas ou em elevação, maior intensidade luminosa e maior disponibilidade de água e nutrientes minerais. Por sua vez, o perfilhamento basal tende a diminuir ou 
cessar com a elongação da haste em decorrência do estímulo ao florescimento (Robson et al., 1989).

O intenso perfilhamento basal observado no início da estação de crescimento é a expressão da combinação dos fatores ambientais. Todavia, com o crescimento instala-se a competição por luz elevando a mortalidade de perfilhos, caso não sejam efetuadas desfolhas. Menor mortalidade de perfilhos, por conta do maior sincronismo no aparecimento dos perfilhos, pode ser obtida com a adubação nitrogenada que estimula o aparecimento de perfilhos e folhas, mas reduz a duração do periodo de perfilhamento (Langer, 1963).

O efeito do nitrogênio sobre o perfilhamento é influenciado pela luminosidade. disponibilidade hídrica e pelo momento da aplicação do adubo. Este nutriente deverá estar disponível no período em que a planta estimula todos os sítios de crescimento para a reconstituição da parte aérea, que em Panicum maximum ocorre até sete dias após a desfolha (Corsi, 1986).

A produção de forragem após a desfolha é definida tanto pelo número como pelo peso de cada perfilho. No início da estação de crescimento, havendo condições ambientais favoráveis e sincronismo no desenvolvimento das gemas, a competição entre perfilhos se instalará mais cedo, o que, em tese, definiria com maior precocidade a estabilidade na densidade de perfilhos por planta. Todavia, a densidade de perfilhos, foi considerada por Langer (1958) em qualquer época como sendo "nada mais que o censo de uma população em contínua mudança".

A dinâmica na densidade de perfilhos decorre do balanço entre aparecimento e morte dos mesmos. Na estação de crescimento as condições favoráveis inicialmente permitem 0 intenso desenvolvimento das gemas definindo elevada densidade de perfilhos, porém com a elevação do IAF, instalase a competição por luz, reduzindo a densidade de perfilhos (Andrade, 1987). Por sua vez, com o crescimento ocorre o aumento do peso do perfilho, cuja variação dependerá das condições ambientais, influenciando a taxa de 
aparecimento de folhas e elongação do colmo, que são maiores com o estímulo ao florescimento (Langer, 1974; Corsi, 1986).

Pedreira (1975) acompanhou o perfilhamento em plantas de Panicum maximum cultivar Colonião não submetidas à desfolha desde a semeadura. $O$ perfilhamento foi menos intenso nos $2 / 3$ finais do verão (janeiro-março) e no final do outono (maio-junho), sendo atribuido tal comportamento ao desenvolvimento intenso das plantas e à frutificação

Alcântara et al. (1991) apresentaram resultados complementares ao trabalho desenvolvido por Alcântara et al. (1985) e Ghisi et al. (1989) acerca do número médio de perfilhos por planta em seis cultivares de Panicum maximum submetidos à adubação de manutenção. Em média o cultivar $I Z-1$ apresentou menor número de perfilhos por planta que o cultivar Aruana, tanto na estação chuvosa como na estação seca, não havendo diferenças dentro de cultivar entre as estações. Houve efeito do tipo de adubação apenas na estação seca, talvez em decorrência da mesma ter sido efetuada no final das águas. O menor número de perfilhos do cultivar IZ-1 em relação ao cultivar Aruana pode ter decorrido do menor porte do último e ao fato do mesmo elevar rapidamente os meristemas apicais que sendo decapitados pelos cortes ao longo do período de avaliação, estimularam o perfilhamento (Alcântara et al., 1985). Todavia, pelo menor porte. o maior número de perfilhos do cultivar Aruana não implicou maior produção de forragem ( Ghisi et al., 1989).

As variações decorrentes do crescimento livre de desfolhas em três genótipos de Panicum maximum, foram apresentadas por Andrade (1987). Os genótipos foram cultivados em linhas espaçadas em $0,25 \mathrm{~m}$ e as parcelas foram adubadas em setembro com o equivalente a $100 \mathrm{~kg} \mathrm{ha}^{-1}$ de $N, 17,4 \mathrm{~kg} \mathrm{ha}^{-1}$ de $P$ e $50 \mathrm{~kg} \mathrm{ha}^{-1}$ de $\mathrm{K} . \mathrm{O}$ acompanhamento da dinâmica do número de perfilhos deuse por 252 dias. À medida que transcorreu o tempo verificou-se que a densidade de perfilhos $\left(n^{\circ} \mathrm{m}^{-2}\right)$ decresceu e o peso médio dos perfilhos aumentou. 0 cultivar IZ-1 com 28, 56, 84, 112, 140, 168, 196, 224 e 252 dias de crescimento apresentou $353,245,196,101,101,111,90,70$ e 61 perilhos $\mathrm{m}^{-2}$, 
respectivamente, enquanto, que para os mesmos periodos, o peso médio dos perfilhos era de 0,$3 ; 1,9 ; 2,6 ; 7,8 ; 9,1 ; 8,4 ; 9,9 ; 10,0$ e $16,8 \mathrm{~g}$.

Num experimento conduzido em câmara de crescimento, HARRIS et al. (1981) avaliaram os efeitos da temperatura (alta $24^{\circ} \mathrm{C}$ dia/18 ${ }^{\circ} \mathrm{C}$ noite ; baixa $14^{\circ} \mathrm{C}$ dia/8 ${ }^{\circ} \mathrm{C}$ noite) e sua alternância e da freqüência de cortes (2 ou 4 semanas) sobre a produção de matéria seca e o número de perfilhos em Lolium perenne $\left(\mathrm{C}_{3}\right)$ e Paspalum dilatatum $\left(\mathrm{C}_{4}\right)$. Observaram efeito da interação graminea e temperatura, com as maiores produções de matéria seca da parte aérea e perfilhamento nas temperaturas mais altas ocorrendo em Paspalum plicatulum. Sendo que a passagem das plantas para um regime de menor temperatura reduziu o crescimento e o perfilhamento.

\subsubsection{Folha, colmo e material senescido}

O fracionamento da forragem acumulada em folha, colmo e material senescido descreve melhor as alterações morfológicas e fisiológicas decorrentes do crescimento e desenvolvimento da planta forrageira, bem como serve para caracterizar, parciaimente, a estrutura da pastagem. Além disso, as decisões de manejo, a eficiência no aproveitamento da forragem e conversão em produto animal mantêm estreita relação com estes parâmetros.

Entre as frações da parte aérea, as folhas destacam-se por constituírem o aparato fotossintético e pela sua composição química e bromatológica, que respondem em maior proporção pela produtividade animal a partir do consumo preferencial ou seletivo pelos animais (Ludlow, 1978; Hacker \& Minson, 1981).

As taxas de aparecimento e de expansão das folhas têm estreita relação com o crescimento e o desenvolvimento da planta. Sofrem alterações por conta do ambiente, do próprio crescimento da área foliar e da maturidade da planta (Anslow, 1966).

Com o crescimento ou a maturidade, a eficiência fotossintética das folhas reduz-se, afetando o balanço entre fotossíntese e respiração na planta (Vickery, 
1981), em grande parte pelo sombreamento, ocasionando a morte de perfilhos ou das folhas mais velhas, constituindo o material senescido ligado à planta. Esta fração apresenta baixo consumo pelos animais, quando ainda há forragem verde disponivel. A maior participação desta fração é indicativo elou acarretará baixo rendimento no aproveitamento da forragem produzida.

Sob pastejo as perdas por senescência são decorrentes do manejo que visa manter elevada área foliar residual, via desfolhas menos freqüentes ou intensas, para assegurar maior produtividade da planta forrageira (Harris, 1981; Hodgson et al., 1981).

A relação entre a taxa de crescimento e a taxa de senescência é direta quando considerado o efeito da temperatura sobre ambas. Há variação estacional em ambas, sendo menor no inverno, embora não implique menor quantidade de material senescido nesta época. Outros fatores como o déficit hídrico, a baixa umidade relativa do ar ou a ocorrência de geada contribuem para o acúmulo de material senescido na pastagem nesta época. As adubaçōes, permitindo maior crescimento, também elevam a taxa de senescência, exigindo maior atenção no manejo para aproveitamento da forragem (Wilson \& Mannetje, 1978).

Em pastagens com alta participação de material senescido, a profundidade de pastejo é definida pelo horizonte do material senescido, que limita o tamanho da bocada e o consumo de forragem (Forbes, 1988).

Nas gramíneas cespitosas tropicais o estímulo ao crescimento associa-se com a elevação na participação da haste na forragem, alterando a estrutura da pastagem e afetando o aproveitamento das folhas (Corsi, 1986; Forbes, 1988). O aproveitamento da fração colmo ou das hastes reduz-se progressivamente entre os estádios iniciais do crescimento e os estádios mais avançados, pois em geral o decréscimo no valor nutritivo ocorre mais rapidamente do que nas outras frações (Hacker \& Minson, 1991). Além disso, com o crescimento há maior participação desta fração na forragem acumulada afetando o comportamento em pastejo e a ingestão de forragem pelos animais. 
Minson (1992) relatou que em seis cuitivares de Panicum maximum foram observadas diferenças no consumo por ovelhas de até $50 \%$ entre os genótipos, para uma mesma digestibilidade da matéria seca. Porém, o cultivar com maior proporção de folhas foi o mais consumido pelos animais.

Os trabalhos clássicos de Stobbs $(1973 a, b)$ demonstraram que o hábito de crescimento e a maturidade nas plantas cespitosas tropicais representaram limitações à apreensão e ao consumo de forragem, uma vez que o maior comprimento dos entre-nós nas plantas maduras diminui a densidade de folhas $\left(\mathrm{kg} \mathrm{cm}^{-1}\right)$ nos estratos das pastagens, reduzindo o tamanho da bocada. Para compensar esta restrição, os animais têm que ampliar o tempo de pastejo elou a taxa de bocadas para assegurar o mesmo nivel de ingestão de forragem. Deste modo, o tamanho da bocada está mais relacionado com a densidade de folhas ou com a relação folha/caule do que com a altura das plantas, implicando maior desfolha pelos animais na porção superior do dossel vegetal. Todavia, para as espécies de clima temperado, o tamanho da bocada eleva-se linearmente com a altura da pastagem em decorrência da maior uniformidade na densidade e pela altura com que as mesmas são manejadas (Forbes, 1988).

Mannetje e Ebersohn (1980) sugeriram que trabalhos de seleção e melhoramento genético de plantas visando elevar a densidade de folhas na haste e a relação folha/caule deveriam ser implementados em forrageiras tropicais para favorecer o consumo voluntário de forragem que é limitado pela estrutura da pastagens tropicais.

Nas condições tropicais, as informações acerca da produção de forragem nem sempre vêm acompanhadas da participação das frações que a compõem, porque em grande parte o principal fator limitando o desempenho animal é a escassez de forragem, sendo que o principal atributo da planta a ser considerado passa a ser produção da parte aérea.

Quando adotadas lotaçōes compativeis com a oferta de forragem, a participação das frações é o principal diferencial para o desempenho animal, por conta da seleção da dieta. Euclides et al. (1989) relataram que não foi obtida 
qualquer relação entre o ganho de peso vivo por animal ou hectare e a pressão de pastejo quando esta última foi calculada com base na matéria seca total da parte aérea. porém a relação foi positiva quando considerou-se no cálculo apenas a matéria seca da forragem verde.

Avaliando Paspalum spp., Pizarro \& Carvalho (1992) obtiveram para o crescimento de verão em 42 genótipos, uma relação, em peso seco, folha verde:talo verde variando de $10: 1$ a $0,6: 1$, enquanto que a relação, em peso seco, tecido vivo:material senescido variou de 2,9:1 a 0,04:1. Por sua vez, Andrade (1987) registrou para o Panicum maximum cultivar $I Z-1$, quando em crescimento livre na estação chuvosa, que o material senescido passou a compor a forragem colhida $(>10 \mathrm{~cm}$ ) após 168 dias de crescimento, mas com um total de $2,9 \mathrm{Mg} \mathrm{ha}^{-1} \mathrm{MS}\left(18,5 \%\right.$ do total), alcançando $5,9 \mathrm{Mg} \mathrm{ha}^{-1} \mathrm{MS}(31,8$ $\%)$ após 252 dias de crescimento. No período entre 28 e 140 dias de crescimento, o material verde (folha+colmo) variou de 1,0 a $13,6 \mathrm{Mg} \mathrm{ha}^{-1} \mathrm{MS}$, respectivamente. Por sua vez, a relação lâmina: haste variou de 1,2:1 ( aos 28 dias) a 0,25:1 (aos 252 dias).

Jank (1994) apresentou valores para a produção de matéria seca foliar no período das águas de cinco cultivares de Panicum maximum, obtidos de experimentos em seis locais no Brasil. As médias variaram de 2,8 a $5,2 \mathrm{Mg} \mathrm{ha}^{-1}$, o que equivaleu de 36 a $54 \%$ do total produzido nas águas.

\subsection{Teores de nutrientes minerais em plantas forrageiras}

Os teores dos minerais na planta forrageira são utilizados, principalmente, para a diagnose nutricional. Também fornecem indicativos do grau de exigência 
da pianta forrageira e da necessidade de reposição dos nutrientes no solo para a manutenção da produtividade.

Pelo conhecimento das funções, mobilidade na planta e das relações entre os nutrientes, os padrões de comportamento dos teores dos nutrientes em grande parte são conhecidos (Raij, 1991). Porém, a magnitude das variaçöes nos teores nas frações da planta não são bem conhecidas.

Para a nutrição animal, a planta forrageira pode atender parcialmente, qualitativamente e quantitativamente, as exigências de minerais dos animais, uma vez que a essencialidade $e$ as quantidades exigidas para o crescimento diferem entre a planta e o animal. Todavia, para os nutrientes requeridos pelo animal é desejável que a planta forrageira responda majoritariamente pelo suprimento (Boin, 1985).

Apesar do amplo campo de aplicação apresentado pelas informações sobre a composição mineral das plantas, a sua utilização deve ser criteriosa, principalmente para as forrageiras, pois apresenta caráter dinâmico, estando influenciada por inúmeros fatores, adquirindo maior complexidade quando há o efeito do animal.

Os teores dos minerais na planta forrageira são influenciados pelo genótipo, idade, estágio fenológico, ritmo de crescimento, disponibilidade de nutrientes no solo e fração da planta considerada (Corsi \& Silva, 1985). Com este elevado número de variáveis influenciando a planta e o comportamento do animal em pastejo, é limitado o entrelaçamento das informações entre estes dois compartimentos.

Inúmeros trabalhos na área de nutrição mineral de plantas foram concuzidos com Panicum maximum, tendo sido elucidadas várias questões, enquanto que para Paspalum spp. são bastante limitadas as informações no ambiente tropical, até porque ainda não houve no País lançamento de cultivar para este ambiente.

$\mathrm{Na}$ tabela 1 são apresentados, para algumas situações, os teores de nutrientes minerais em Panicum maximum e em Paspalum spp., bem como os 
teores requeridos na dieta de bovinos. Embora de forma combinada com os efeitos do ambiente e do manejo, são observadas diferenças nos teores entre e dentro das espécies para um dado nutriente, bem como do comportamento na planta frente à disponibilidade dos mesmos. Também, supondo que a forragem não limita o consumo, constatam-se diferenças na capacidade dos genótipos em atender às exigências dos animais.

As informações disponiveis sobre a composição mineral das espécies forrageiras, em boa parte foram obtidas como variáveis complementares ao objetivo do trabalho, e como refletem o efeito combinado de diversos fatores, têm valor limitado quando são supostas outras situações de manejo. Jones (1992) alertou para limitações da análise comparativa de teores de nutrientes entre espécies de gramíneas, pois a disponibilidade de nutrientes no solo e a pressão de pastejo exercem maior efeito do que sobre as leguminosas.

Um dos principais agentes responsáveis pelas alterações nos teores dos minerais na planta forrageira é o crescimento. Na tabela 2 são apresentados teores de nutrientes minerais de frações da parte aérea de Panicum maximum após períodos de crescimento. Pode-se verificar que o comportamento é diferenciado entre os nutrientes de uma mesma fração e que as variações ocorrem em taxas diferentes com o crescimento. $O$ comportamento registrado pelos nutrientes nas frações tem sido explicado, além da mobilidade e função dos mesmos, pelos efeitos de diluição ou concentração decorrentes do maior ou menor ritmo de crescimento, respectivamente. Todavia, estes efeitos nem sempre são caracterizados corretamente, pois, por exemplo, reduções nos teores de um mineral com o tempo de crescimento podem decorrer da redução da disponibilidade no solo deste nutriente, e não somente ao crescimento que o dilui na planta (Jarrel \& Beverly, 1981).

Pela praticidade na amostragem, pela sensibilidade apresentada e por representar a fração selecionada pelos animais êm pastejo, a folha tem sido a fração da planta mais utilizada para fins de diagnose nutricional (Meirelles et al., 1988). 
Tabela 1. Teores de nutrientes minerais na parte aérea de Panicum maximum e Paspalum spp. em diferentes condiçōes de crescimento e teores exigidos na dieta de bovinos. Compilação de vários trabalhos. Médias sublinhadas $=$ Paspalum spp. $F=$ folha: $C=$ colmo: $P A=$ parte aérea .

\begin{tabular}{|c|c|c|c|c|c|c|c|c|c|c|c|}
\hline \multirow[t]{2}{*}{ Condição } & $\mathrm{N}$ & $P$ & $\mathrm{~K}$ & $\mathrm{Ca}$ & $\mathrm{Mg}$ & $S$ & $\mathrm{~B}$ & $\mathrm{Cu}$ & $\mathrm{Fe}$ & $\mathrm{Mn}$ & $\mathrm{Zn}$ \\
\hline & \multicolumn{6}{|c|}{$g(100 \mathrm{~g})^{-1}$} & \multicolumn{5}{|c|}{$\mathrm{mg}(\mathrm{kg})^{2}$} \\
\hline \multicolumn{12}{|l|}{ Pastagens } \\
\hline PA-Coloniāo & 1,73 & 0,21 & 2,11 & 0,42 & 0,24 & 0,07 & 15 & 7 & 124 & 90 & 21 \\
\hline PA-Batatais' & $\underline{1,41}$ & $\underline{0,23}$ & 1,95 & $\underline{0.46}$ & $\underline{0,26}$ & $\underline{0,06}$ & 14 & $\underline{7}$ & $\underline{142}$ & 116 & $\underline{20}$ \\
\hline PA-Makueni' & $\overline{2,19}$ & $\overline{0,32}$ & $\overline{1,53}$ & & & & & & & & \\
\hline PA-Bryan² & 2.24 & 0,25 & 1,48 & & & & & & & & \\
\hline PA-Aruana $^{12}$ & 1,15 & & & & & & & & & & \\
\hline PA- $\mid Z-1^{12}$ & 1,23 & & & & & & & & & & \\
\hline PA-FCAP-0 $8^{8}$ & 1.54 & & & & & & & & & & \\
\hline PA-Paspalum spp, ${ }^{y}$ & 1,70 & & & & & & & & & & \\
\hline \multicolumn{12}{|l|}{ Solução Nuttritiva } \\
\hline \multicolumn{12}{|l|}{ Coloniâo } \\
\hline$\overline{F-C o m p l e t a "}$ & 1,50 & 0,11 & 1,84 & 0,40 & 0,12 & & & & & & \\
\hline F - Omissão & 0,79 & 0,08 & 1,17 & 0,29 & 0,05 & & & & & & \\
\hline PA-Completa ${ }^{3}$ & 1,06 & 0,10 & 2,33 & 0,55 & 0,22 & & & & & & \\
\hline PA-Omissão & 0,67 & 0,07 & 1,10 & 0,37 & 0,06 & & & & & & \\
\hline \multicolumn{12}{|l|}{ Tobiatã } \\
\hline$\overline{\text { F-Completa }^{4.0}}$ & 2,06 & 0,15 & 2,99 & 1,18 & 1,52 & 0,16 & 19 & 2 & 79 & 42 & 27 \\
\hline F-Omissão, & 1,0 & 0,08 & 0,47 & 0,19 & 0,12 & 0,08 & 23 & 0,8 & 81 & 41 & 31 \\
\hline
\end{tabular}

Nivel Critico Interno

\begin{tabular}{|c|c|c|c|c|c|c|c|c|c|c|c|}
\hline $\begin{array}{l}\text { Solução Nutritiva } \\
\text { Colonião }\end{array}$ & & & & & & & & & & & \\
\hline Foiha $^{\sigma}$ & & 0,29 & & & & & & & & & \\
\hline Colmo & & 0,14 & & & & & & & & & \\
\hline Parte Aérea & & 0.24 & & & & & & & & & \\
\hline \multicolumn{12}{|l|}{ Vasos - IZ-1 } \\
\hline Latossolo- Foiha & & $0,17-0,29$ & & & & & & & & & \\
\hline Podzólico-Folha' & & $0,16-0,19$ & & & & & & & & & \\
\hline \multicolumn{12}{|l|}{ Requerimentos } \\
\hline \multicolumn{12}{|l|}{ Gado de Corte $^{10}$} \\
\hline Sugerido & $*$ & * & 0,65 & * & 0,1 & 0,1 & - & 8 & 50 & 40 & 30 \\
\hline Amplitude $^{D}$ & a & $7-26^{c}$ & $0,5-0,7$ & $11-56^{\circ}$ & $0,05-0,25$ & $0.08-0,15$ & - & $4-10$ & $50-100$ & $20-50$ & $20-40$ \\
\hline \multicolumn{12}{|l|}{ Gado de Leite" } \\
\hline Amplitude $^{D}$ & $1,6-3.5$ & $0,19-0,6$ & $0,6-0,9$ & $0,29-0,77$ & $0,1-0,25$ & $0.16-0.25$ & - & 10 & $50-100$ & 40 & 40 \\
\hline $\begin{array}{l}\text { 1- GALLO et al } \\
\text { FRANÇA \& } \\
\text { 9- PIZARRC } \\
\text { a- Exigência co } \\
\text { de produção }\end{array}$ & $\begin{array}{l}\text { 74) } 2-C \\
\text { G (1986 } \\
\text { ARVAL } \\
\text { roteina } \\
\text { Requer }\end{array}$ & $\begin{array}{l}\text { DOK \& N } \\
6-\mathrm{MA} \\
10(1992 \\
\text { ruta : } 34 \\
\text { hentos d }\end{array}$ & $\begin{array}{l}\text { LDER ( } \\
\text { IINEZ (1 } \\
\text { lo- NRC } \\
\text { a } 1057 \\
\text { orrem d }\end{array}$ & $\begin{array}{l}\text { 84b) 3- } \\
80) 7- \\
\text { 1984) } \\
\text { dia }^{-1} \text { de } \\
\text { vários fa }\end{array}$ & $\begin{array}{l}\text { ERNER } \\
\text { =IRELLE } \\
\text { NRC (1 } \\
\text { otéina B }\end{array}$ & $\begin{array}{l}\text { 1971) } 4-F F \\
\text { et al. (19 } \\
\text { 88) } 12-\mathrm{GH} \\
\text { ita conform } \\
\text { vivo, prod }\end{array}$ & e & $\begin{array}{l}\text { HA } \\
\text { ST } \\
(19 \\
\text { ria }\end{array}$ & $\begin{array}{l}\text { G(1985 } \\
\text { et al. }(1 \\
\text { imal e }\end{array}$ & $\begin{array}{l}5- \\
92) \\
\text { vel } \\
\text { i-1 }\end{array}$ & \\
\hline
\end{tabular}


Tabela 2. Teores de nutrientes minerais em frações da parte aérea de Panicum maximum em períodos de crescimento.Compilação de vários

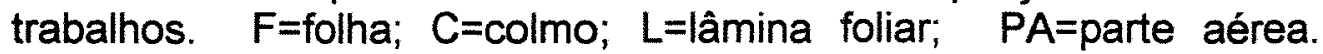
Médias sublinhadas=lâmina foliar

\begin{tabular}{|c|c|c|c|c|c|c|c|c|c|c|c|c|c|c|c|c|c|c|c|}
\hline \multirow[b]{2}{*}{ Dias } & \multicolumn{2}{|c|}{$\mathrm{N}^{*}$} & \multicolumn{2}{|c|}{$\mathrm{P}^{*}$} & \multicolumn{2}{|c|}{$\mathrm{K}^{\star}$} & \multicolumn{2}{|c|}{$\mathrm{Ca}^{*}$} & \multicolumn{2}{|c|}{$\mathrm{Mg}^{*}$} & \multirow{2}{*}{$\frac{S^{*}}{F}$} & \multicolumn{2}{|c|}{$\mathrm{Cu}^{\star \star}$} & \multicolumn{2}{|c|}{$\mathrm{Fe}^{\star \star \star}$} & \multicolumn{2}{|c|}{$M n^{\star \star}$} & \multicolumn{2}{|c|}{$\mathrm{Zn}$} \\
\hline & $F$ & C & $\bar{F}$ & $P A$ & $F$ & PA & $L$ & PA & $\bar{F}$ & PA & & $F$ & $\mathrm{PA}$ & $L$ & $\mathrm{PA}$ & $\bar{F}$ & PA & $\bar{F}$ & $\mathrm{PA}$ \\
\hline 28 & & & $\frac{0.26^{\circ}}{0}$ & $0,29^{\circ}$ & $\underline{2,47^{\circ}}$ & $0,94^{0}$ & $0.84^{\circ}$ & $\left|0,76^{\circ}\right|$ & $0.47^{\circ}$ & $0,51^{\circ}$ & $\underline{0.15^{a}}$ & $\underline{9^{a}}$ & $24^{\circ}$ & $784^{\circ}$ & $725^{5}$ & $\underline{261^{\circ}}$ & $172^{\circ}$ & $34^{\circ}$ & $36^{D}$ \\
\hline 30 & $2,80^{\mathrm{a}}$ & $1,88^{2}$ & $0,22^{a}$ & & $2,64^{a}$ & & & & $0,2^{a}$ & & $0,26^{a}$ & $48^{\mathrm{a}}$ & & & & $162^{a}$ & & $55^{\circ}$ & \\
\hline 45 & $2,84^{a}$ & $1,71^{a}$ & $0,24^{\mathrm{a}}$ & & $2,69^{\mathrm{a}}$ & & & & $0,2^{\mathrm{a}}$ & & $0,23^{\mathrm{a}}$ & $53^{a}$ & & & & $132^{a}$ & & $44^{a}$ & \\
\hline 50 & & & $\frac{0,23^{c}}{4}$ & & & & $0.54^{c}$ & & & & & & & & & & & & \\
\hline 56 & & & $0,24^{\circ}$ & & $1,48^{d}$ & & $\underline{0.88^{\circ}}$ & & $0,55^{\circ}$ & & $0,12^{d}$ & $\underline{8}^{d}$ & & $\underline{242^{d}}$ & & ${\underline{289^{d}}}^{-1}$ & & $28^{d}$ & \\
\hline 60 & $3,07^{\circ}$ & $2,11^{a}$ & $0,17^{\circ}$ & & $2,53^{4}$ & & & & $0,2^{a}$ & & $0,24^{2}$ & $30^{\circ}$ & & & & 103 & & $44^{a}$ & \\
\hline 68 & & & $\underline{0.12^{c}}$ & & & & $0,47^{c}$ & & & & & & & & & & & & \\
\hline 75 & $2,19^{\circ}$ & $1,44^{\mathrm{a}}$ & $0,13^{n}$ & & $2,63^{a}$ & & & & $0,2^{a}$ & & $0,34^{a}$ & $20^{\circ}$ & & & & 106 & & $42^{\circ}$ & \\
\hline 84 & & & $0.18^{d}$ & $0,19^{b}$ & $1.32^{d}$ & $0,48^{\circ}$ & $0.85^{\circ}$ & $0,56^{b}$ & $0,46^{d}$ & $0,45^{\circ}$ & $\underline{0,09^{d}}$ & $\underline{5}^{d}$ & $18^{\circ}$ & $\underline{223^{4}}$ & $352^{\circ}$ & $232^{\circ}$ & $162^{\circ}$ & $32^{4}$ & $36^{\circ}$ \\
\hline 89 & & & $\frac{0.15^{c}}{}$ & & & & $0.5 t^{6}$ & & & & & & & & & & & & \\
\hline 110 & & & $0,15^{c}$ & & & & $\frac{0.62^{c}}{1}$ & & & & & & & & & & & & \\
\hline 112 & & & $0.15^{d}$ & & $1.09^{d}$ & & $0,67^{\circ}$ & & $0,33^{d}$ & & $0,06^{d}$ & $4^{d}$ & & $\underline{230^{d}}$ & & $\underline{208^{d}}$ & & $21^{d}$ & \\
\hline 132 & & & $0.12^{c}$ & & & & $0.59^{\circ}$ & & & & & & & & & & & & \\
\hline 140 & & & $0.14^{\circ}$ & $0,13^{\circ}$ & $\underline{0.92^{6}}$ & $0,28^{D}$ & $\frac{0,91^{\circ}}{}$ & $0,67^{\circ}$ & $\underline{0,39^{0}}$ & $0,46^{b}$ & $0.07^{\mathrm{d}}$ & $\underline{4}^{\mathrm{a}}$ & $19^{b}$ & $323^{d}$ & $484^{\circ}$ & $\underline{256^{\circ}}$ & $190^{\circ}$ & $19^{d}$ & $32^{b}$ \\
\hline 152 & & & $0.11^{\circ}$ & & & & $\frac{0.58^{c}}{}$ & & & & & & & & & & & & \\
\hline 196 & & & & $0,12^{b}$ & & $0,28^{b}$ & & $0,75^{\circ}$ & & $0,5^{b}$ & & & $20^{\circ}$ & & $261^{\circ}$ & & $200^{\mathrm{b}}$ & & $31^{\circ}$ \\
\hline 252 & & & & $0,12^{b}$ & & $0,18^{\mathrm{D}}$ & & $0,75^{\circ}$ & & $0,46^{\circ}$ & & & $20^{b}$ & & $195^{\circ}$ & & $258^{\circ}$ & & $39^{b}$ \\
\hline
\end{tabular}

a- VIEIRA et al. (1980) b- GOMIDE et al. (1969) c- PEDREIRA \& SILVEIRA (1972) d- ANDRADE (1987)

* $-\mathrm{g}(100 \mathrm{~g})^{-1} ;{ }^{* \star} \mathrm{mg}(\mathrm{kg})^{-1}$ 
Entre os nutrientes minerais, o nitrogênio destaca-se pelos incrementos que proporciona na produção de forragem e na produção animal, graças às peculiaridades dos ruminantes em relação ao aproveitamento da fração nitrogenada não ligada às proteínas e à demanda para a digestão da fração fibrosa da forragem (Soest, 1982). Quando expressado como proteína bruta, seu teor é um dos indicadores do valor nutritivo da planta forrageira, o qual é menor com a idade ou a maturidade da planta forrageira, podendo também ser incrementado pelas adubações nitrogenadas (Boin, 1986), podendo ou não diferir entre as frações folha e colmo (Minson, 1992). A tabela 3 ilustra o comportamento dos teores de proteína bruta (Teor de $N \times 6,25$ ) nas frações da parte aérea de Panicum maximum e Paspalum spp. com o crescimento.

As exigências protéicas dos bovinos variam principalmente conforme a condição fisiológica e o nível de produção, e o atendimento dos requerimentos está relacionado com o nível de ingestão. Segundo o Nacional Research Council - NRC - (1984), a amplitude dos requerimentos de proteína bruta na dieta em bovinos de corte varia diretamente com o peso vivo e com o ganho de peso vivo diário, de $363(58,08 \mathrm{~g} \mathrm{~N})$ a $1057(169,12 \mathrm{~g} \mathrm{~N}) \mathrm{g} \mathrm{dia}^{-1}$. Para os animais envolvidos com melhoramento genético as exigências variam de 6,8 a $16,4 \mathrm{~g}$ $(100 \mathrm{~g})^{-1}$ da dieta. Para NRC (1978), os menores requerimentos numa dieta para a manutenção seriam de vacas secas $\left(5,9 \mathrm{~g}(100 \mathrm{~g})^{-1}\right)$ e de novilhos entre $300 \mathrm{e}$ $500 \mathrm{~kg}$ de peso vivo $\left(8,5 \mathrm{~g}(100 \mathrm{~g})^{-1}\right)$. Para bovinos leiteiros as exigências variam, conforme NRC (1988), entre 10 e $22 \mathrm{~g} \mathrm{(100} \mathrm{g)})^{-1}$ de proteína bruta na dieta conforme o nível de produção e a condição fisiológica do animal. 
Tabela 3. Médias para períodos ou dias de crescimento nos teores de proteína bruta $\left(\mathrm{g}(100 \mathrm{~g})^{-1}\right)$ em Panicum maximum e Paspalum spp. Sublinhado $=$ Paspalum spp.; Negrito= Folhas; Itálico= Colmos;

\begin{tabular}{|c|c|c|c|}
\hline $\begin{array}{l}\text { Dias ou } \\
\text { períodos }\end{array}$ & Parte aérea & Lâminas foliares & Hastes \\
\hline \multicolumn{4}{|l|}{ Dias } \\
\hline 7 & $18,1 i$ & & \\
\hline 14 & $15,1 \mathrm{i}$ & & \\
\hline 21 & $12,1 \mathrm{i}-12,1 \mathrm{~g}-11,5 \mathrm{~h}$ & & \\
\hline 28 & $10,7 \mathrm{i}-22,6 \mathrm{~b}$ & & \\
\hline 28 & $19,1 a$ & $19,7 a$ & $21,0 a$ \\
\hline 30 & 14,21 & & \\
\hline 30 & $13,5 \mathrm{~m}$ & & \\
\hline 35 & $\overline{77,8 i}$ & & \\
\hline 42 & $6,9 i-10,4 g-9,61 \mathrm{~h}$ & & \\
\hline 47 & $10,3 n$ & & \\
\hline 49 & $6,0 i$ & & \\
\hline 50 & $17,7 \mathrm{c}$ & $19,8 \mathrm{c}$ & $16,7 \mathrm{c}$ \\
\hline 56 & $5,7 i$ & & \\
\hline 56 & $16,2 a$ & $16,75 a$ & $15,1 \mathrm{a}$ \\
\hline 63 & $5,6 \mathrm{i}-7,8 \mathrm{q}-7,1 \mathrm{~h}$ & & \\
\hline 68 & $12,6 \mathrm{c}$ & $14,4 \mathrm{c}$ & $12,6 \mathrm{c}$ \\
\hline 84 & $12,6 a-6,3 g-5,8 h$ & $13,3 a$ & $10,9 a$ \\
\hline 89 & $12,6 \mathrm{c}$ & $14,6 c$ & $12,6 c$ \\
\hline 110 & $11,1 \mathrm{c}$ & $12,9 \mathrm{c}$ & $8,6 c$ \\
\hline 112 & $9,3 a$ & $10,9 a$ & $6,2 a$ \\
\hline 132 & $8,9 \mathrm{c}$ & $11,9 c$ & $6,3 c$ \\
\hline 140 & $9,0 a-9,4 b$ & $12,0 a$ & $7,7 a$ \\
\hline 152 & $7,7 \mathrm{c}$ & $11,3 \mathrm{c}$ & $5,9 c$ \\
\hline 168 & $5,7 a$ & $8,1 a$ & $5,4 a$ \\
\hline 196 & $6,6 b$ & $6,9 b$ & $4,4 a$ \\
\hline 224 & $5,0 a$ & $7,0 a$ & $4,3 a$ \\
\hline 252 & $4,3 a$ & $8,2 a$ & $4,8 \mathrm{a}$ \\
\hline \multicolumn{4}{|l|}{ Períodos } \\
\hline & $\begin{array}{c}6,8 \mathrm{q}-7,2 \mathrm{e} \\
7,7 \mathrm{f}-8,9 \mathrm{j} \\
10,6 \mathrm{o}-14 \mathrm{r}\end{array}$ & 12,90 & 8,20 \\
\hline
\end{tabular}

a- ANDRADE (1987); b- GOMIDE et al. (1969); c- PEDREIRA \& SILVEIRA (1972); d-COWARD-LORD et al. (1974); $\theta$ - GUISI et al (1989) - cv. Aruana - Média Verão; \&- GUISI et al. (1989) - cv. IZ-1 - Média Verăo; g- COSTA et al. (1992) P.guenoarum; $h$ - COSTA et al. (1992) P. coryphaeum; - ARROYO-AGUILÚ et al. (1975) - média de 5 gramineas; j- ARROYO-AGUlLU et al. (1975): $k$ - STANLEY et al. (1977) - cv. Pensecola; 1- KAYONGO-MALE et al. (1976) - Média de 20 genótipos; m-KAYONGO-MALE et al. (1976) - Paspalum spp.-Média de 12 genótipos; n-PIZARRO \& CARVALHO (1992) - Paspalum spp. - Média de 42 genótipos; o- BENEDETT et al. (1994) - Média entre 7-63 dias; p- RODRIGUEZ et al. (1994) - Média entre 7 - 63 dias; q- COWARD-LORD et al. (1974) - Média de 12 gramineas;; r- BROWN et al. (1976). 


\section{MATERIAL e MÉtodos}

\subsection{Localização e clima}

Os experimentos foram conduzidos na Estação Experimental Central do Instituto de Zootecnia, em Nova Odessa, SP, Brasil (22 $42^{\prime}$ latitude Sul, $47^{\circ} 18^{\prime}$ Longitude Oeste; $550 \mathrm{~m}$ de altitude) no período entre 25 de agosto de 1993 e 9 de março de 1994.

O clima do local é do tipo Aw (Köppen), com precipitação pluvial de 1297 $\mathrm{mm}$ ano ${ }^{-1}$, sendo $84 \%$ deste total distribuído entre os meses de setembro e abril. A média anual da temperatura média do ar é de $21^{\circ} \mathrm{C}$, com a menor média registrada no mês de julho $\left(16,9^{\circ} \mathrm{C}\right.$ ) (Cosentino et al., 1988).

\subsection{Instalação}

Em experimentos individuais avaliou-se a campo a produção cumulativa da forragem, de seus componentes da produção e a composição mineral das gramíneas Panicum maximum Jacq. cultivar $\mathrm{Z} Z-1$, Panicum maximum Jacq. cultivar Aruana e Paspalum coryphaeum Trin. NO 174 quanto em crescimento contínuo.

Os experimentos foram instalados em áreas com pastagens exclusivas de cada gramínea, formadas há mais de três anos e utilizadas preferencialmente para a produção de sementes, sendo também pastejadas por bovinos e eqüinos sem um manejo bem definido. Nestas pastagens as gramineas Panicum 
maximum cultivar Aruana e Paspalum coryphaeum NO 174 foram estabelecidas num espaçamento de $0,5 \mathrm{~m}$ entre as linhas, enquanto que o Panicum maximum cultivar IZ-1 foi estabelecido no espaçamento de 1,0 m entre as linhas, as quais ainda preservavam o seu alinhamento. Tendo em vista a produção de sementes, adubações químicas de manutenção eram efetuadas nas mesmas.

O solo das áreas foi classificado como podzólico vermelho amarelo variação Laras, sendo os resultados da análise química em amostras de terra ao início dos período experimental apresentados na tabela 4.

A uniformização das áreas foi efetuada mecanicamente com roçadeira acoplada a trator, com a altura do corte menor que $10 \mathrm{~cm}$. Após a roçada, o material distribuido pela superfície foi removido mecanicamente com ancinho enleirador acoplado a um trator e/ou manualmente. Em seguida procedeu-se a demarcação da área, e a adubação da mesma, à lanço, em área total, com o equivalente a $100 \mathrm{~kg} \mathrm{ha}^{-1}$ de $\mathrm{N}, 35 \mathrm{~kg} \mathrm{ha}^{-1}$ de $\mathrm{P}$ e $50 \mathrm{~kg} \mathrm{ha}^{-1}$ de $\mathrm{K}$, tendo como fontes o sulfato de amônio, o superfosfato simples e o cloreto de potássio, respectivamente.

\subsection{Condução}

\subsubsection{Tratamentos}

As gramíneas foram avaliadas nos intervalos de crescimento de 4, $6, \quad 8,14$ e 22 semanas após a uniformização e adubação das áreas. Os menores intervalos de crescimento foram adotados por corresponderem às freqüências de desfolhas mais comuns para as forrageiras tropicais nesta estação, enquanto que os maiores intervalos buscavam detectar a estabilização na produção de forragem. As datas em que foram realizadas as amostragens estão contidas na tabela 5 . 


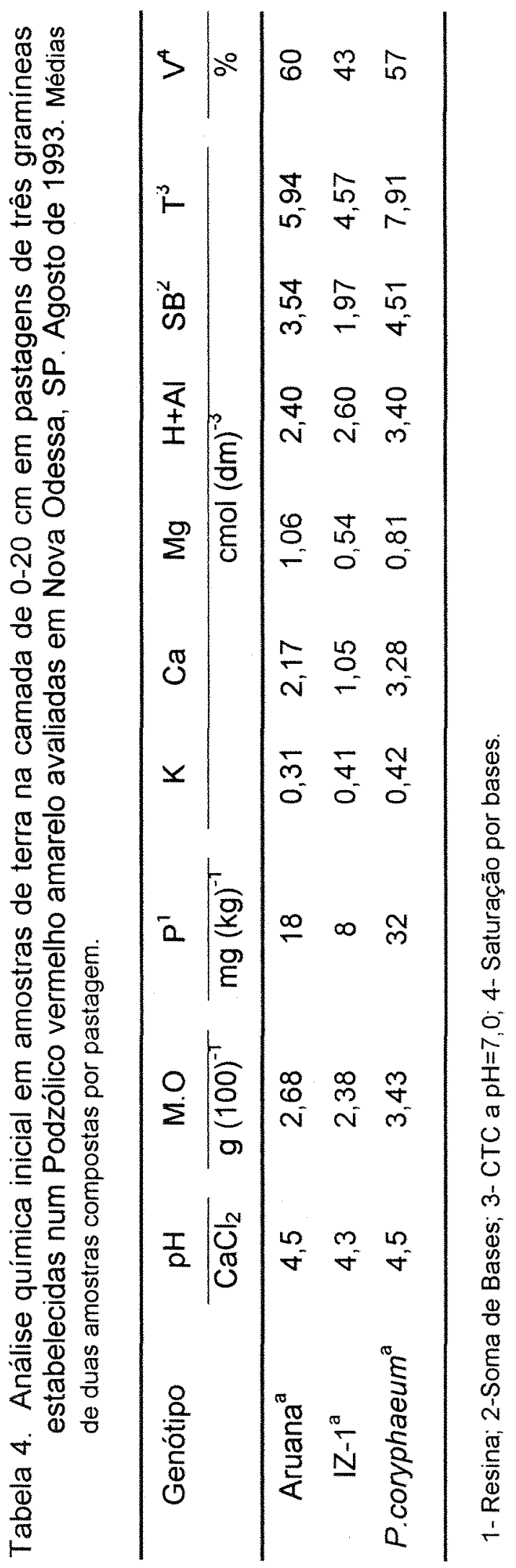




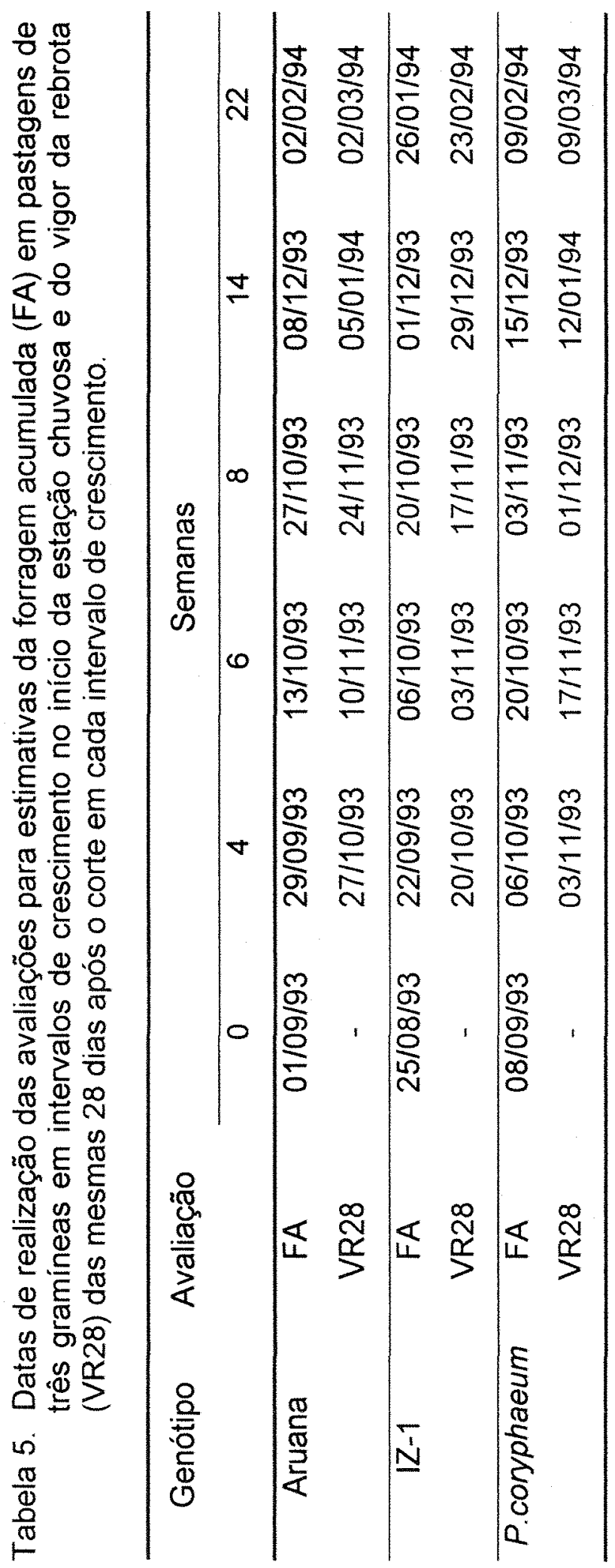




\subsubsection{Avaliações}

As avaliações foram efetuadas em parcelas de $4,0 \times 4,0 \mathrm{~m}$ para cada intervalo de crescimento. As variáveis consideradas foram: a altura da planta, a densidade de perfilhos, o peso médio dos perfilhos, a produção de matéria seca total da parte aérea (corte rente ao solo), a produção de matéria seca como forragem [corte a $10 \mathrm{~cm}$ do solo - Aruana e NO 174 - ou a $15 \mathrm{~cm}$ do solo - IZ-1], a matéria seca de colmos, folhas e material morto, a porcentagem de eliminação dos meristemas apicais, vigor da rebrota (acúmulo de matéria seca 28 dias após a amostragem para a estimativa da produção de forragem de cada intervalo de crescimento) e a composição mineral.

Em cada data, em seis pontos nas respectivas parcelas, foram tomadas medidas ao acaso da altura da cultura (ALT). Para tanto considerou-se como limite superior o nível definido pela curvatura da lâmina na última folha expandida.

As parcelas foram visualmente divididas em duas partes para fins de amostragem da parte aérea. Nestas subparcelas, a área amostrada para o cultivar $I Z-1$ foi de $1,0 \mathrm{~m}^{2}$, definida por uma armação metálica de $1,0 \times 1,0 \mathrm{~m}$, enquanto que para as demais gramíneas a área amostrada foi de $0,5 \mathrm{~m}^{2}$, a partir da tomada de dois pontos ao acaso com uma moldura de $0,5 \times 0,5 \mathrm{~m}$.

Numa das subparcelas, definida ao acaso, efetuou-se a contagem do número de perfilhos basais para estimativa da densidade (NP), seguida do corte manual rente à superfície do solo para a determinação do peso médio (PMP) e da produção de matéria seca total acumulada na parte aérea (MSPA). $\mathrm{Na}$ outra subparcela fez-se a estimativa da matéria seca considerada como forragem (MSFOR), amostrando-se manualmente a parte aérea numa altura do corte de $15 \mathrm{~cm}$ para o cultivar IZ-1 e de $10 \mathrm{~cm}$ nas demais gramíneas. Nestas amostras efetuou-se a separação manual das frações folhas vivas (MSFV), 
colmos (MSC) e material senescido ligado à planta (MSS). Em seguida, uniformizou-se toda a parcela numa altura idêntica à adotada para a amostragem da forragem ( 10 ou $15 \mathrm{~cm}$ ). Nos menores intervalos de crescimento a uniformização foi efetuada manualmente, e nos maiores intervalos utilizou-se motosegadeira de barra frontal com altura do corte ajustável. O material ceifado foi rastelado e removido da parcela, e na subparcela onde amostrou-se acima do nível do solo, para a estimativa da produção de forragem (MSFOR), foram identificados 30 perfilhos ao acaso com fios coloridos para a estimativa da eliminação de meristemas apicais (PEMA) em cada intervalo de crescimento..

Nos perfilhos identificados previamente nas subparcelas verificou-se a eliminação de seus meristemas apicais através da análise das lâminas foliares emitidas (truncadas ou não) quando transcorridos sete dias após a uniformização das parcelas, estimando-se a porcentagem de eliminação dos mesmos em relação ao total de perfilhos marcados.

Nas subparcelas em que avaliou-se a eliminação de meristemas apicais e quando transcorridos 28 dias do corte para estimativa da forragem acumulada, em cada intervalo de crescimento, fez-se nova amostragem da forragem acumulada para a estimativa do vigor da rebrota (VR28).

No material amostrado elou separado determinou-se 0 peso verde $e$ foram retiradas subamostras que novamente foram pesadas e postas para secar em estufa a $65^{\circ} \mathrm{C}$ por no mínimo 72 horas, para as estimativas baseadas no peso seco.

Em cada ocasião, o peso médio dos perfilhos (PMP) foi obtido pela estimativa da matéria seca da parte aérea (MSPA) dividida pelo número de perfilhos. A fração considerada como forragem (MSFOR), foi estimada pelo somatório das frações folha verde (MSFV), colmo (MSC) e material senescido (MSS). Considerou-se como forragem viva (MSFORV) o somátorio das frações colmo e folha vivas. 


\subsubsection{Análises químicas}

Do material seco em estufa, as folhas e colmos foram moídos (malha 1 $\mathrm{mm}$ ) e acondicionados em sacos plásticos para serem analisados os teores de minerais. Nas folhas foram analisados os teores de $\mathrm{N}, \mathrm{P}, \mathrm{K}, \mathrm{Ca}, \mathrm{Mg}, \mathrm{S}, \mathrm{B}, \mathrm{Cu}$, $\mathrm{Fe}, \mathrm{Mn}$ e $\mathrm{Zn}$, enquanto que nos colmos apenas o teor de $\mathrm{N}$. A metodologia adotada foi descrita por Sarruge \& Haag (1974), sendo os teores expressos com base matéria seca a $105^{\circ} \mathrm{C}$.

\subsubsection{Análise estatística}

O delineamento experimental utilizado foi 0 de blocos completos casualizados com três repetições. Todas as variáveis foram submetidas à analise de regressão (PROC GLM) e uma vez identificados os efeitos significativos $(P<0,05)$ foram estimados os coeficientes das equações de regressão linear do tipo polinomial (PROC REG), tendo como variável independente o intervalo de crescimento em semanas (Steel \& Torrie, 1960; Sas, 1988).

Quando as estimativas obtidas pelos polinômios não apresentavam significado biológico optou-se, desde que significativo, pelos polinômios de menor grau. Para as variáveis que representavam contagem ou valores em porcentagem, a transformação dos dados não trouxe ganhos para a análise de regressão. Desta forma, foram utilizadas as médias originais.

Efetuou-se a análise de correlação linear simples (PROC CORR) entre as variáveis pelo método de Pearson (Steel \& Torrie, 1960; Sas, 1988)

\subsubsection{Dados climáticos}

Os principais parâmetros climáticos registrados nos meses e nos intervalos de crescimento em que as gramíneas foram avaliadas foram 
obtidos no posto meteorológico do Instituto de Zootecnia em Nova Odessa$\mathrm{SP}$, sendo apresentados nas tabelas $6,7,8$ e 9. 


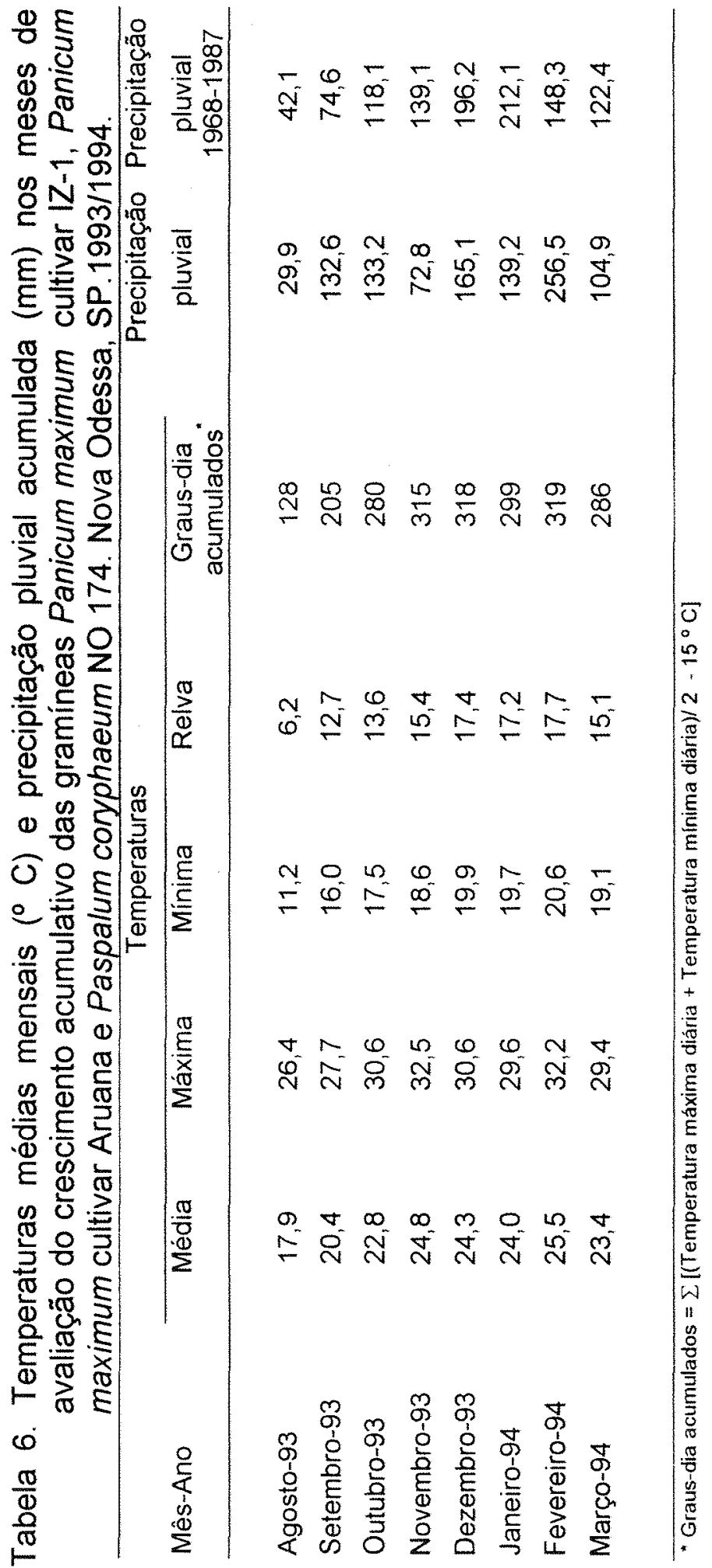




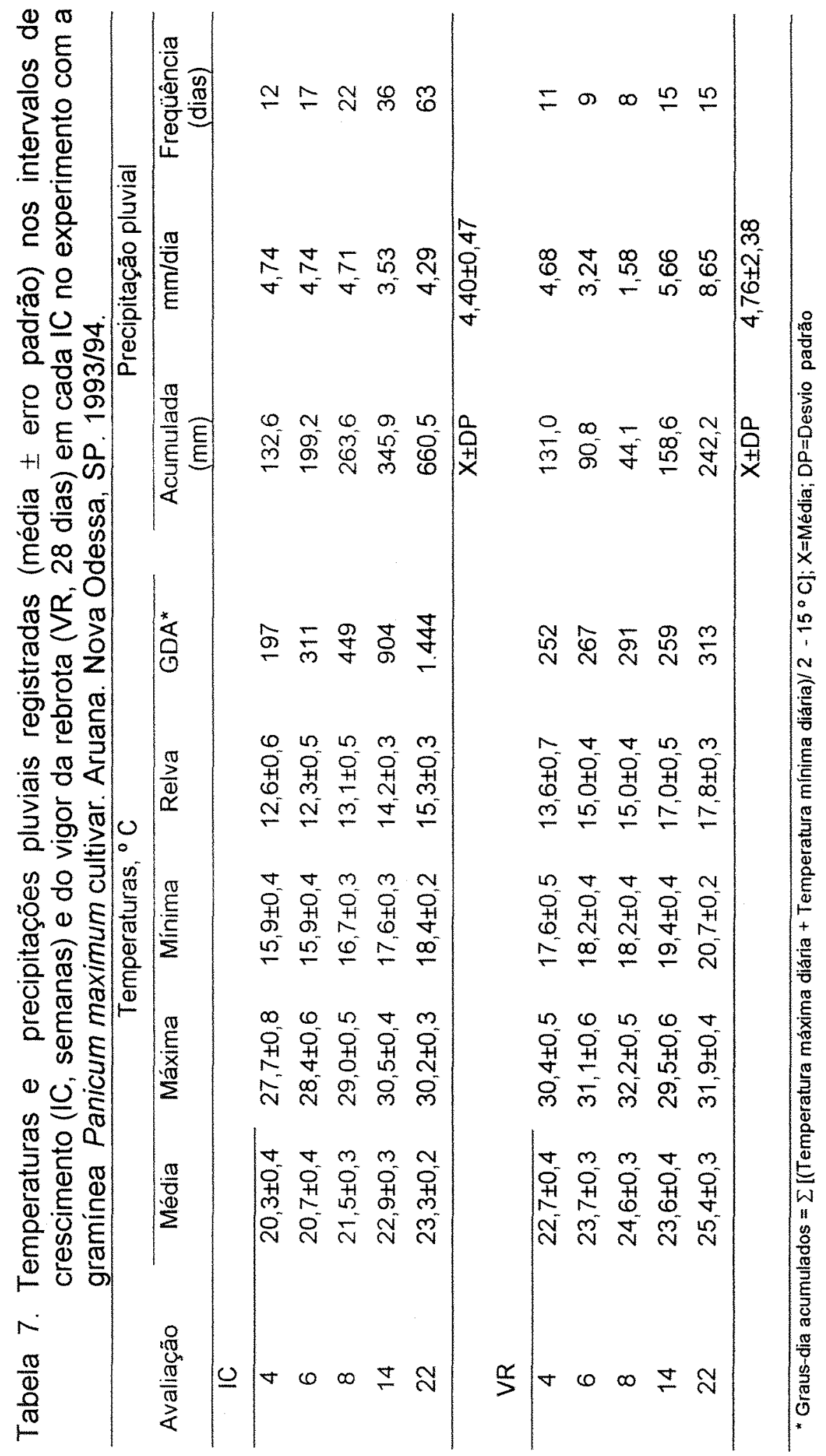




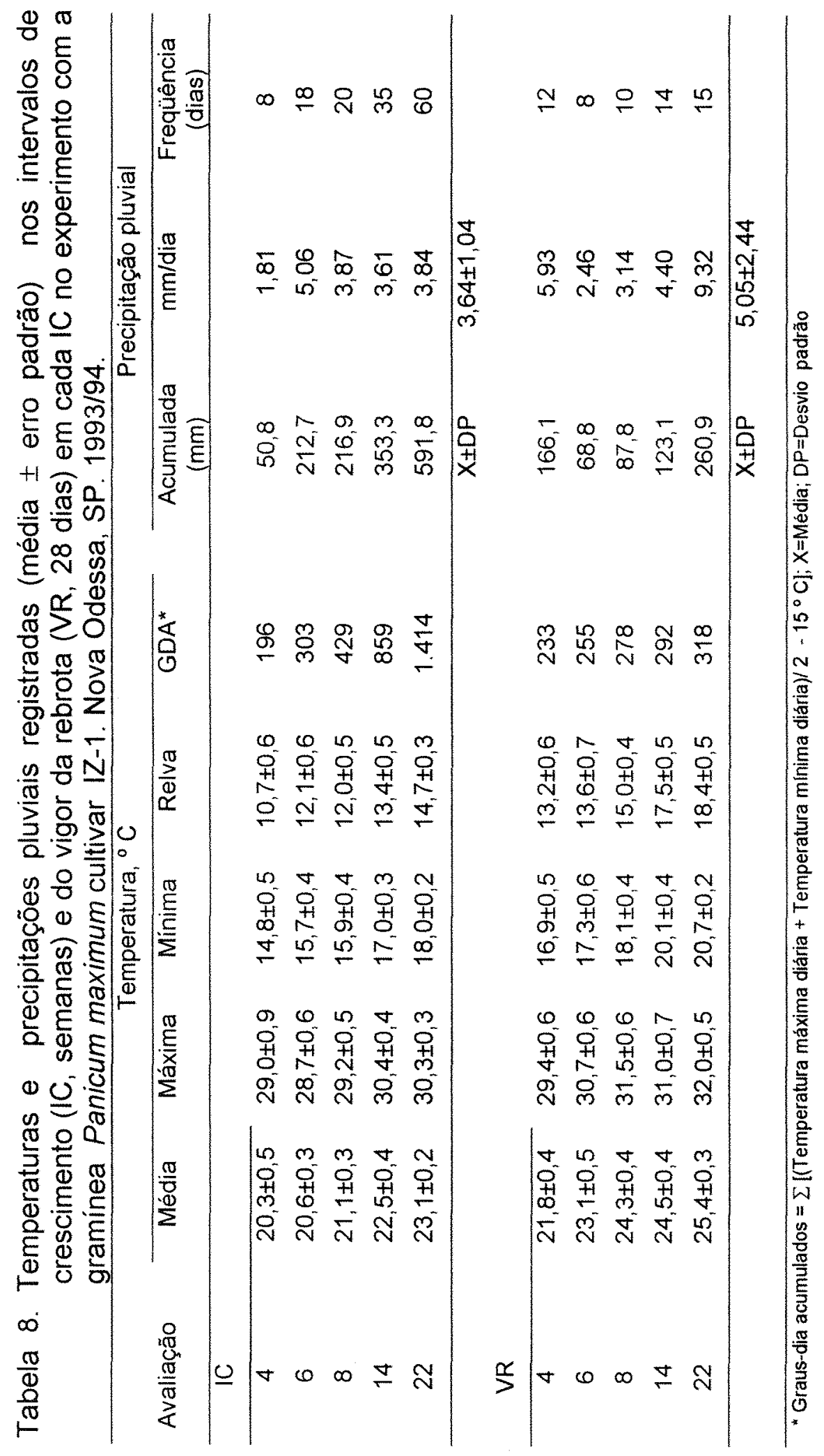




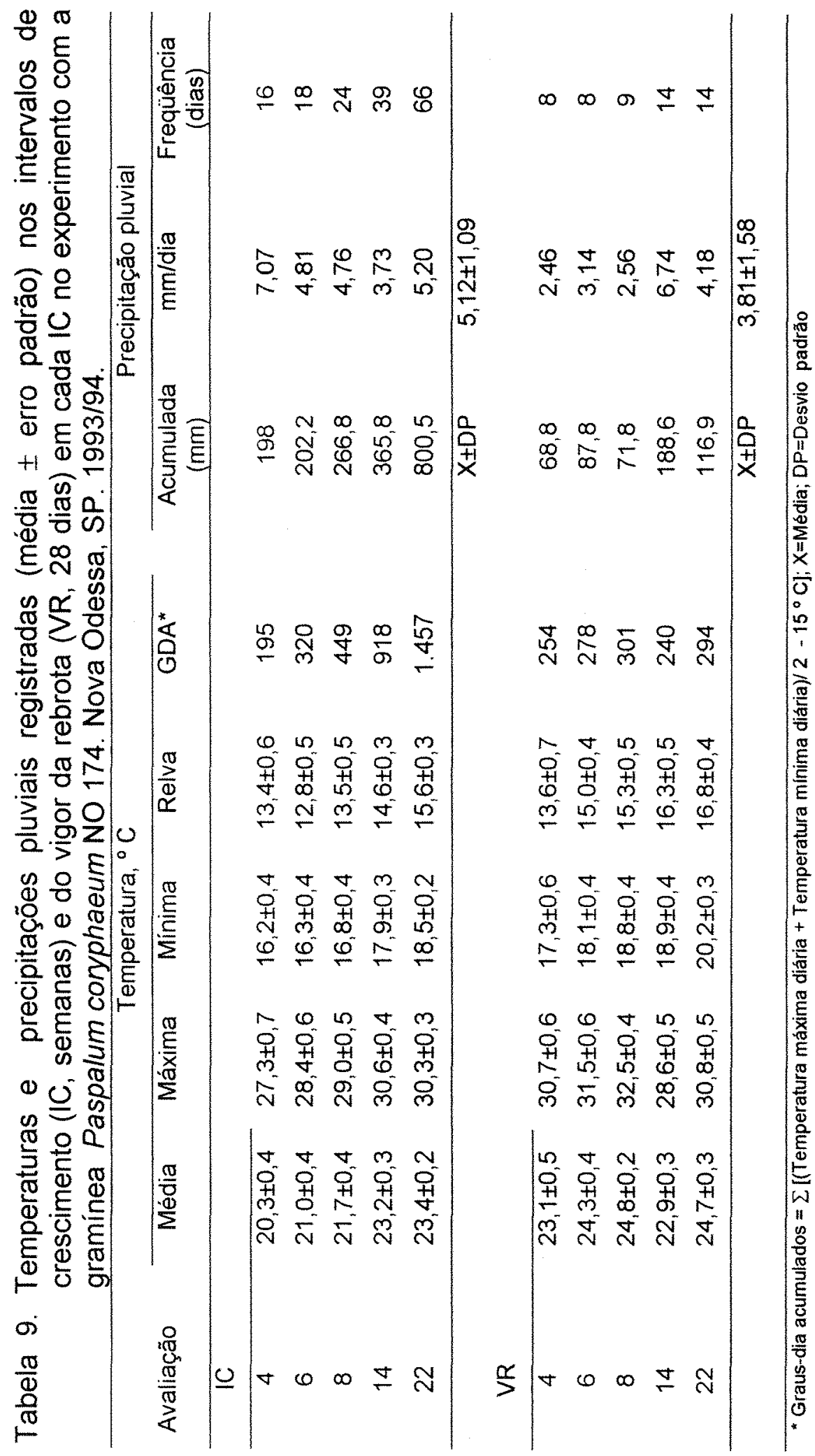




\title{
4. Resultados e Discussão
}

\subsection{Crescimento e componentes da produção de forragem}

\begin{abstract}
4.1.1. Panicum maximum cultivar Aruana
As médias originais dos parâmetros agronômicos ligados à produção de matéria seca da forragem do cultivar Aruana estão contidas na tabela 10.

\subsubsection{Produção de matéria seca da parte áerea}

O comportamento produtivo do cultivar Aruana nos intervalos de crescimento é apresentado na figura 1.

A produção de matéria seca na parte aérea não registrou o comportamento padrão descrito por uma curva do tipo sigmóide, quando seriam detectados dois pontos de inflexão. Para tanto os intervalos entre as avaliações deveriam ser menores na fase inicial do crescimento conforme sugeriu Hunt (1982). Todavia, do ponto de vista agronômico o segmento linear da curva de produção de matéria seca a ser explorado foi bem caracterizado.
\end{abstract}




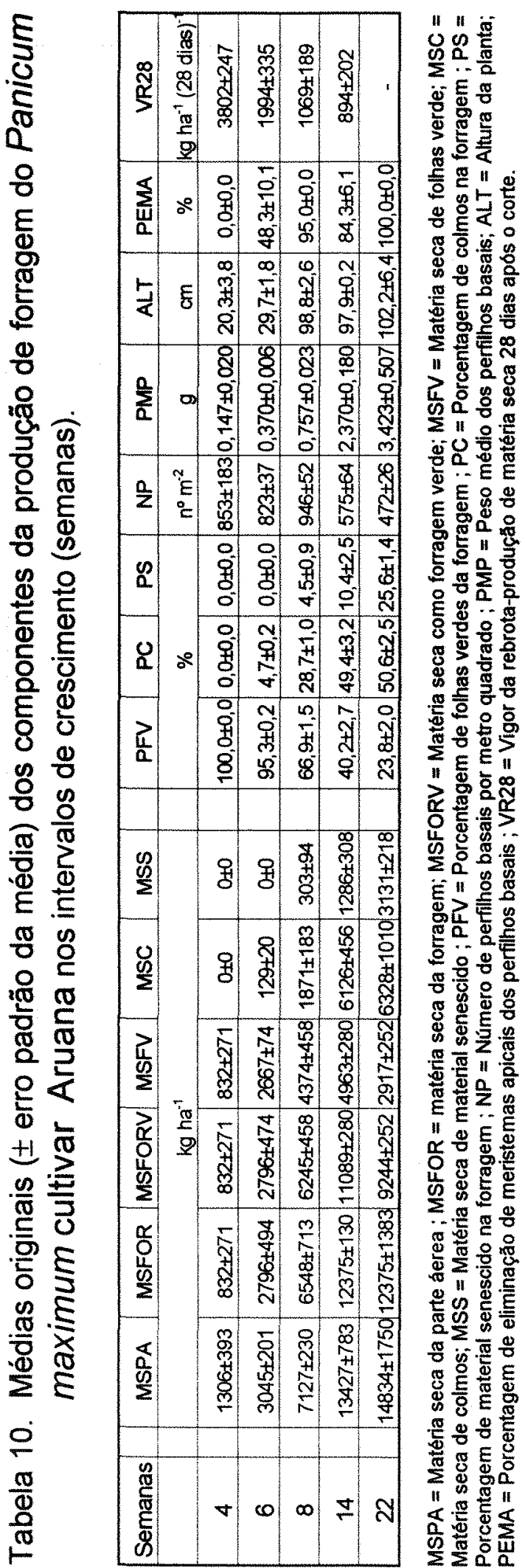




$\begin{array}{lll}\text { MSPA } & Y=-7508+2266 X-56,7 X^{2} & R^{2}=0,94 \\ \text { MSFOR } & Y=-7990+2314 X-63 X^{2} & R^{2}=0,94 \\ \text { MSFORV } & Y=-7723+2289 X-68,9 X^{2} & R^{2}=0,93 \\ \text { MSFV } & Y=-2895+1169 X-41,3 X^{2} & R^{2}=0,97 \\ \text { MSC } & Y=1315-907 X+156 X^{2}-4,75 X^{3} & R^{2}=0,93 \\ \text { MSS } & Y=-23,9 X+7,64 X^{2} & R^{2}=0,97 \\ & & n=15 P<0,05\end{array}$

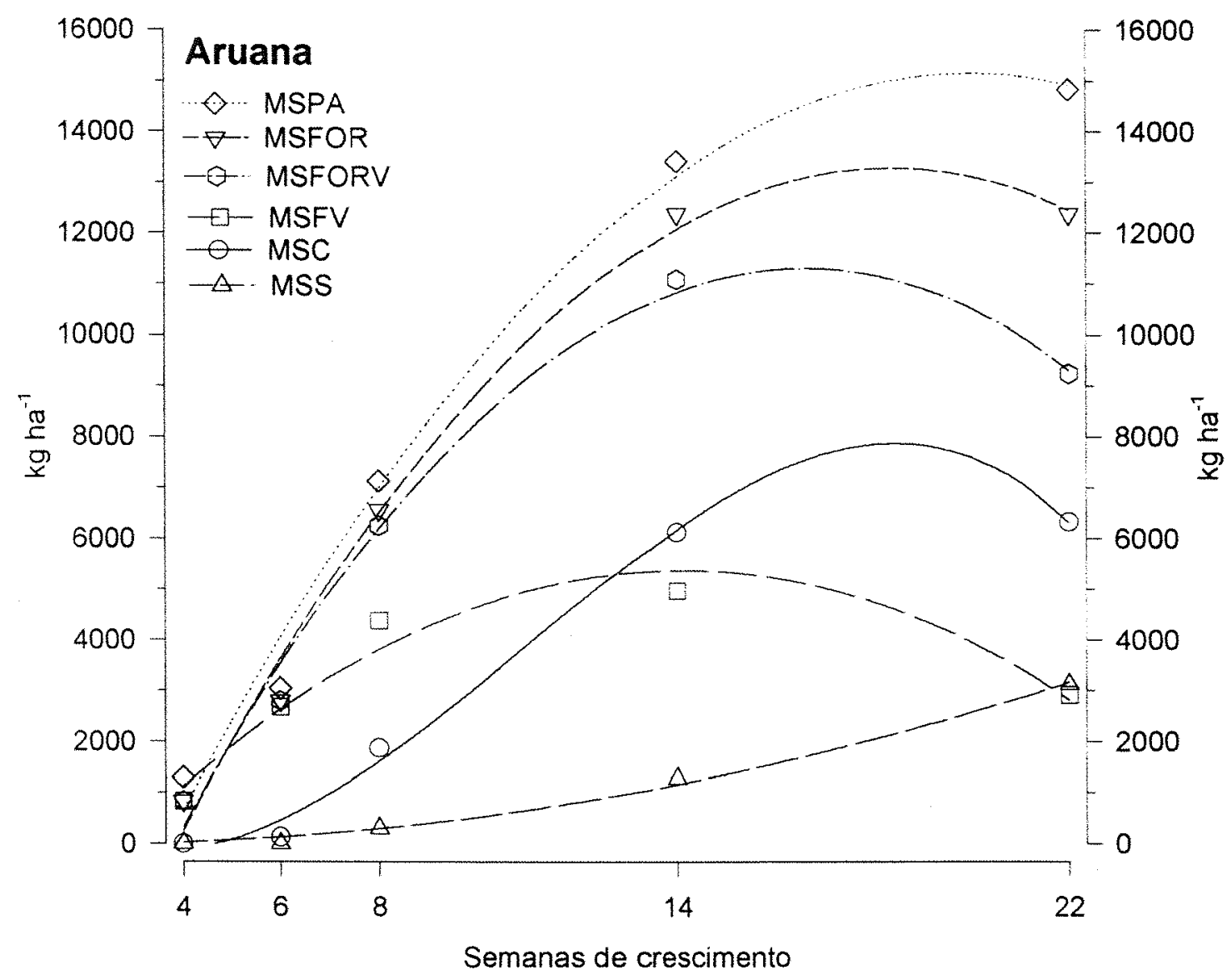

Figura 1. Produção de matéria seca (MS) da parte aérea e de componentes da forragem do Panicum maximum cultivar Aruana em intervalos de crescimento no início da estação chuvosa. Nova Odessa, SP. 1993/94. MSPA= Parte aérea; MSFOR= Forragem $(>10 \mathrm{~cm}) . M S F O R V=$ Forragem Verde; MSFV= Folhas Verdes; $M S C=$ Colmos; MSS= Material senescido. 
A produção de matéria seca da parte aérea (corte ao nível do solo) apresentou resposta quadrática aos intervalos de crescimento. As médias registradas variaram de $1,3 \mathrm{Mg} \mathrm{ha}^{-1}$ (com 4 semanas) a $14,8 \mathrm{Mg} \mathrm{ha}^{-1}$ (com 22 semanas), sendo por volta de 20 semanas de crescimento a estimativa para o máximo acúmulo de matéria seca.

Para a produção de matéria seca da forragem (corte a $10 \mathrm{~cm}$ ) 0 comportamento foi semelhante ao registrado quando amostrou-se a planta inteira, com as médias variando de 0,8 (com 4 semanas) a $12,4 \mathrm{Mg} \mathrm{ha}^{-1}$ (com 22 semanas). A máxima disponibilidade de forragem registrada ocorreu por volta de 14 semanas de crescimento, sendo que a estimada ocorreu por volta de 18 semanas de crescimento (Tabela 10, Figura 1). Essa diferença entre o estimado e o registrado decorre do polinômio que ainda poderia ter seu ajuste melhorado caso tivessem sido tomados alguns pontos intermediários ao intervalo entre $14 \mathrm{e}$ 22 semanas. Todavia, a amostragem após 14 semanas correspondeu propositadamente, em termos fenológicos, ao final da emissão de inflorescências. Deste modo, a produção de forragem ainda pode experimentar posteriormente algum aumento em função do enchimento dos cariopses, mas de pequena magnitude e de importância secundária.

Entre os componentes da forragem a resposta foi quadrática aos intervalos de crescimento para a produção de matéria seca de folhas e de material senescido, enquanto que para a produção de matéria seca de colmos o melhor ajuste foi obtido com o polinômio de terceiro grau (Figura 1). A produção de matéria seca de folhas, que era apenas de $0,8 \mathrm{Mg} \mathrm{ha}^{-1} \mathrm{com} 4$ semanas de crescimento, alcançou $4,4 \mathrm{Mg} \mathrm{ha}^{-1}$ com 8 semanas de crescimento, passando a experimentar decréscimos na sua taxa de acúmulo. A máxima produção de matéria seca de folhas verdes registrada $\left(5,0 \mathrm{Mg} \mathrm{ha}^{-1}\right)$ ocorreu após 14 semanas de crescimento, após o que passou a declinar, mas ainda apresentando $2,9 \mathrm{Mg} \mathrm{ha}^{-1}$ com 22 semanas de crescimento. Este decréscimo, refletiu-se na produção de matéria seca de material senescido, cuja produção de matéria seca era de $0,3 \mathrm{Mg} \mathrm{ha}^{-1} \mathrm{com} 8$ semanas de crescimento, mas atingindo 
1,3 Mg ha ${ }^{-1}$ com 14 semanas de crescimento, permanecendo em elevação, alcançando $3,1 \mathrm{Mg} \mathrm{ha} \mathrm{M}^{-1}$ após 22 semanas de crescimento. Por sua vez, a produção de matéria seca de colmos, que era de apenas $0,13 \mathrm{Mg} \mathrm{ha}^{-1}$ com 4 semanas de crescimento, elevou-se para $6,1 \mathrm{Mg} \mathrm{ha}^{-1}$ com 14 semanas, praticamente não diferindo após 22 semanas. A produção de matéria seca da forragem verde, haja vista a combinação da produção de matéria seca de colmos com a produção de matéria seca de folhas, também apresentou a maior média registrada com 14 semanas $\left(11,1 \mathrm{Mg} \mathrm{ha}^{-1}\right)$, quando também passou a decrescer (Tabela 10, Figura 1).

A produção de forragem com 4 semanas $\left(0,83 \mathrm{Mg} \mathrm{ha}^{-1}\right)$ foi pequena se considerada a quantidade de adubo aplicada, porém para o mesmo intervalo de crescimento situou-se pouco abaixo da relatada por Andrade (1987) para o cultivar IZ-1 (1,0 Mg ha $\left.{ }^{-1}\right)$, cujo porte é maior que o do cultivar Aruana. Todavia, as taxas de acúmulo de forragem e de folhas do cultivar Aruana, que foram maiores entre 4 e 8 semanas de crescimento, permitiram produções de forragem $\left(6,5 \mathrm{Mg} \mathrm{ha}^{-1}\right)$ que corresponderam ao dobro da verificada por Andrade (1987) nos cultivares $\mathrm{Z}$-1 e Tobiatã $\left(2,6-3,3 \mathrm{Mg} \mathrm{ha}^{-1}\right)$ com 8 semanas de crescimento, sendo os dois cultivares também superados quando considerada apenas a produção de folhas registrada pelo cultivar Aruana $\left(4,4 \mathrm{Mg} \mathrm{ha}^{-1}\right)$ neste experimento.

O acúmulo de forragem em menores taxas após 8 semanas de crescimento deveu-se mais ao crescimento dos colmos (de 1,9 para 6,1 $\mathrm{Mg} \mathrm{ha}^{-1}$ entre 8 e 14 semanas), visto que as plantas encontravam-se sob o efeito do estímulo ao florescimento (Figura 1). Vale salientar que a partir da observação de áreas contíguas ao experimento as quais foram roçadas mas não adubadas, verificou-se que a adubação antecipou o início da fase reprodutiva do cultivar Aruana. Deste modo, este cultivar apresentou alta capacidade de produção de forragem, mas modificando a sua fenologia reprodutiva, cujas alterações morfológicas e fisiológicas associadas reduzirão a extensão do período de 
utilização da forragem acumulada, exigindo maior atenção em relação ao manejo para o aproveitamento da forragem.

Embora a produção de matéria seca de folhas tenha experimentado variação positiva no período entre 8 e 14 semanas, o incremento semanal foi de apenas $0,1 \mathrm{Mg} \mathrm{ha}^{-1}$ (Tabela 10), visto que as taxas de aparecimento e elongação das folhas tendem a diminuir com o aumento da área foliar e com a maturidade conforme descreveu Anslow (1966).

A máxima disponibilidade de folhas estimada ocorreu por volta da $14^{a}$ semana de crescimento $\left(5,4 \mathrm{Mg} \mathrm{ha}^{-1}\right)$, sendo $1,6 \mathrm{Mg} \mathrm{ha}^{-1}$ acima do estimado para 8 semanas de crescimento $\left(3,8 \mathrm{Mg} \mathrm{ha}^{-1}\right)$, porém nestes intervalos os valores situaram-se próximos dos relatados por Jank (1994) para a produção anual de folhas em cinco cultivares de Panicum maximum $\left(2,8\right.$ a 5,2 $\left.\mathrm{Mg} \mathrm{ha}^{-1}\right)$, evidenciando a capacidade produtiva deste genótipo na estação de crescimento.

O acúmulo de material senescido ligado à planta ocorreu lentamente até a $8^{\mathrm{a}}$ semana de crescimento ( $38 \mathrm{~kg} \mathrm{ha}^{-1}$ semana $^{-1}$ ), mas rapidamente entre a $8^{\mathrm{a}}$ e a $14^{\mathrm{a}}$ semana ( $163 \mathrm{~kg} \mathrm{ha}^{-1}$ semana $^{-1}$ ), porém ainda sendo compensado pelo aparecimento de novas folhas, uma vez que a disponbilidade de folhas verdes ainda elevava-se. Os efeitos combinados da idade das folhas, do sombreamento e da temperatura em elevação seriam responsáveis pela maior expressão do material senescido com o aumento no intervalo de crescimento, conforme sugeriram Vickery (1981) e Ludlow (1978). A taxa média de acúmulo de material senescido foi de $230 \mathrm{~kg} \mathrm{ha}^{-1}$ semana $^{-1}$ após a $14^{\text {a }}$ semana e como após esse intervalo de crescimento a disponibilidade de folhas verdes iniciou o seu declínio, o aproveitamento da forragem deverá ocorrer preferencialmente antes, considerando-se que a forragem verde apresenta consumo preferencial pelos ruminantes, segundo Hacker \& Minson (1992), e que o material senescido pode representar perdas de acordo com Maraschin (1993). Neste trabalho a produção de material senescido ocorreu mais precocemente para o cultivar Aruana (8 semanas) do que a observada para o cultivar IZ-1 (24 semanas) no trabalho de Andrade (1987), podendo ser atribuído ao desenvolvimento mais precoce do 
cultivar Aruana em relação ao $\mathrm{Z}$-1, além disso a adubação nitrogenada deve ter favorecido o aparecimento de folhas, mas elevando a taxa de senescência das folhas, como puderam constatar Wilson \& Mannetje (1978) em Cenchrus ciliaris.

Na figura 2 é mostrada a participação relativa, em peso seco, das folhas, dos colmos e do material senescido na forragem acumulada nos intervalos de crescimento. A porcentagem de folhas na forragem decresceu à medida que elevou-se o intervalo de crescimento, e de modo inverso, a participação dos colmos (PC) e do material senescido (PS) aumentou. Com 6 semanas, $95 \%$ da forragem era constituída de folhas, mas com 8, 14 e 22 semanas, a participação declinou para 67,40 , e $24 \%$ do total produzido, respectivamente, como conseqüência da maior participação dos colmos e do material senescido. A participação relativa do material senescido com 14 semanas de crescimento, ainda era baixa $(10,4 \%)$, porém se considerada juntamente com os colmos, perfaziam $60 \%$ do total de forragem (Tabela 10, Figura 2). Minson (1992) relatou que diferenças no consumo de forragem de mesma digestibilidade em Panicum maximum estiveram associadas com a maior proporção de folhas na forragem, deste modo maior eficiência no aproveitamento da forragem acumulada deverá ocorrer nos menores intervalos de crescimento. $O$ intervalo de 14 semanas de crescimento possibilitou grande oferta de forragem $(12,4 \mathrm{Mg}$ $\mathrm{ha}^{-1}$ ), porém se considerada apenas a produção de folhas, o incremento foi pequeno em relação ao intervalo de 8 semanas, sendo que a proporção de folhas experimentou redução de $26 \%$ entre esses intervalos. Deste modo, nos sistemas de produção onde a oferta de forragem no início da estação de crescimento é mais crítica ou quando se busca maior eficiência no consumo da forragem, o aproveitamento necessariamente deverá ocorrer antes de 14 semanas, sendo que com 8 semanas alia-se a oferta de forragem, com a maior eficiência na produção de folhas $\left(\mathrm{Mg} \mathrm{ha}^{-1}\right.$ semana $\left.^{-1}\right)$ e a maior proporção das mesmas (> $70 \%$ ) na forragem. 


$\begin{array}{lll}\text { PFV } & Y=142-10,7 X+0,24 X^{2} & R^{2}=0,97 \\ \text { PC } & Y=-40+10,4 X-0,28 X^{2} & R^{2}=0,91 \\ \text { PS } & Y=-7,5+1,44 X & R^{2}=0,94 \\ & & n=15 \quad P<0,05\end{array}$

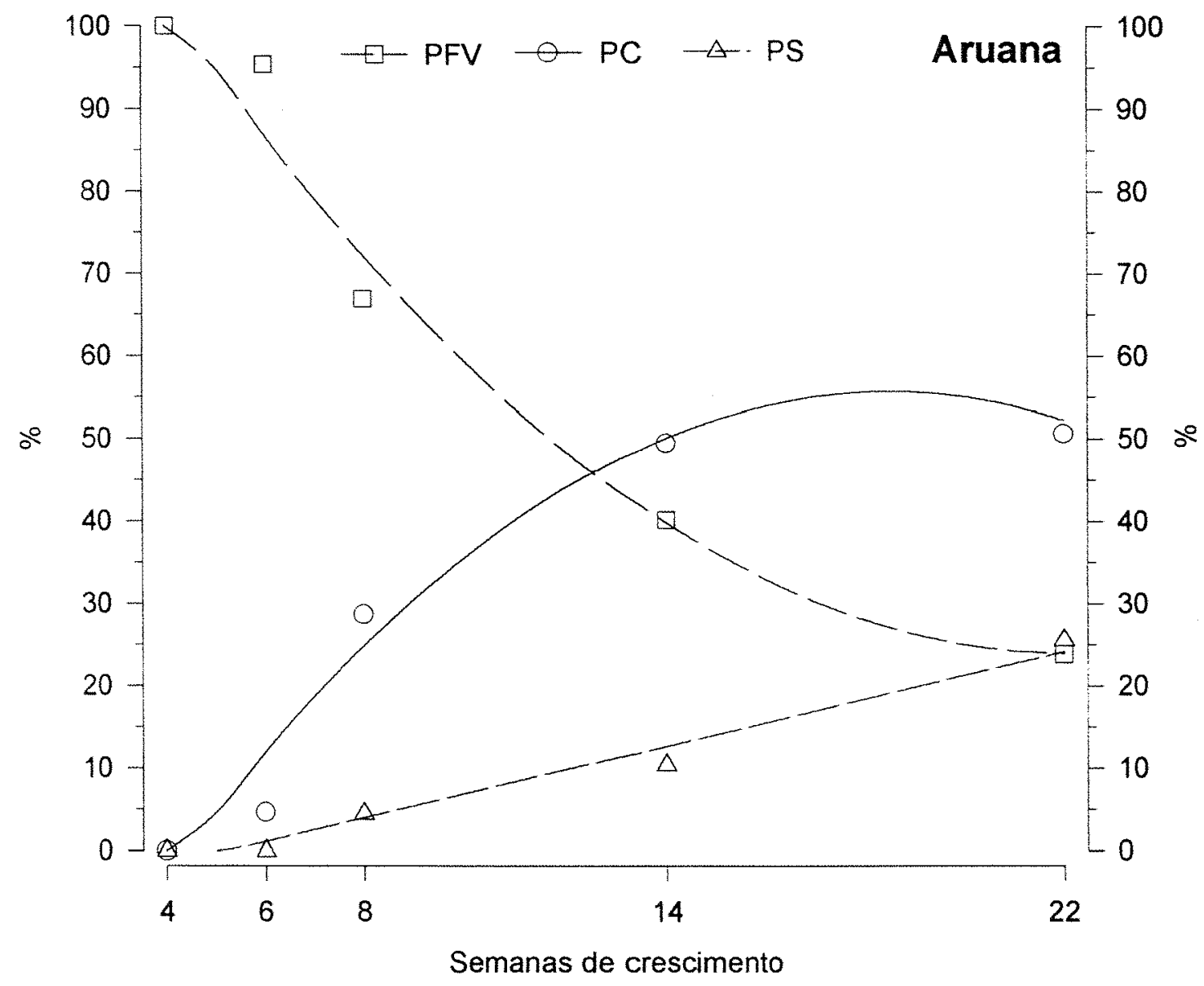

Figura 2. Porcentagem de folhas verdes (PFV), colmos (PC) e material senescido (PS) na forragem acumulada pelo Panicum maximum cultivar Aruana em intervalos de crescimento no início da estação chuvosa. Nova Odessa, SP. 


\subsubsection{Perfilhos}

As variações na densidade e no peso médio dos perfilhos basais com o crescimento da pastagem do cultivar Aruana são apresentadas na figura 3.

Foram registradas densidades de perfilhos variando de 472 (com 22 semanas) a 946 perfilhos $\mathrm{m}^{-2}$ (com 8 semanas), sendo que o polinômio que melhor ajustou-se aos dados, mesmo precariamente, foi o de primeira ordem que estimou as médias como decrescentes entre 4 e 22 semanas de crescimento, definindo a mortalidade líquida em 25 perfilhos $\mathrm{m}^{-2}$ semana ${ }^{-1}$. A amostragem efetuada com 4 semanas de crescimento apresentou menor precisão (853 \pm 183$)$ juntamente com o maior desvio do valor registrado com 8 semanas, em relação à media dos demais intervalos de crescimento, concorreram para o baixo coeficiente de determinação (Tabela 10 Figura 3). No período entre 4 e 8 semanas, a densidade de perfilhos foi, em média, de 876 perfilhos $\mathrm{m}^{-2}$, decresceu para 575 perfilhos $\mathrm{m}^{-2}$ com 14 semanas e atingiu 472 perfilhos $\mathrm{m}^{-2}$ com 22 semanas. Por outro lado, o peso médio dos perfilhos basais sobreviventes aumentou linearmente $0,19 \mathrm{~g}$ semana $^{-1}$ no período entre 4 e 22 semanas de crescimento. Com 4 semanas. o peso médio dos perfilhos era de $0,15 \mathrm{~g}$, atingindo 0,$37 ; 0,76 ; 2,37$ e $3,42 \mathrm{~g}$ após $6,8,14$ e 22 semanas, respectivamente.

A elevada mortalidade de perfilhos registrada com o aumento do intervalo de crescimento foi provavelmente ocasionada pelos processos competitivos, principalmente por luz, que se instalam com o crescimento conforme evidenciaram Ludlow (1978) e Vickery (1981). A taxa de aumento em peso dos perfilhos deve estar em parte relacionada de forma inversa com o número de perfilhos na planta. No trabalho de Andrade (1987) foram registradas menores densidades e maior peso médio de perfilhos nos três genótipos de Panicum maximum avaliados, em relação ao observado para o cultivar Aruana nesse experimento, principalmente nos maiores intervalos de crescimento. $O$ cultivar Aruana com 22 semanas de crescimento apresentou 472 perfilhos $\mathrm{m}^{-2}$, com 
peso médio de $3,4 \mathrm{~g}$, ao passo que o cultivar Tobiatã, no trabalho de Andrade (1987) após 20 semanas de crescimento tinha 270 perfilhos $\mathrm{m}^{-2}$, com peso médio de $5,9 \mathrm{~g}$.

A densidade de perfilhos é dinâmica segundo Langer (1958), sendo que na condição de crescimento contínuo a tendência verificada é a da redução com o aumento no intervalo de crescimento como pôde ser observada na figura 3. É desejável que a planta apresente um elevado número de perfilhos, pois potencialmente, representarão mais sítios para a produção em potencial de forragem ou de sementes. Assim sendo, visando a produção de forragem, cortes efetuados após 8 semanas de crescimento no cultivar Aruana poderão implicar da produção na rebrota.

Considerando-se as produções acumuladas registradas neste experimento nos menores intervalos de crescimento, bem como o porte do cultivar Aruana, pode-se inferir que o seu potencial de produção é definido em grande parte pela sua densidade de perfilhos.

\subsubsection{Eliminação de meristemas apicais e vigor da rebrota}

$\mathrm{Na}$ figura 4 está representado o comportamento produtivo do cultivar Aruana após o corte nos intervalos de crescimento, o qual denominou-se por vigor da rebrota. Também são apresentadas a altura das plantas e a porcentagem de eliminação dos meristemas apicais dos perfilhos basais.

A altura das plantas elevou-se rapidamente com o aumento do intervalo de crescimento, sendo estimada, segundo o polinômio de segundo grau, em 36 $\mathrm{cm}$ com 4 semanas, alcançando $67 \mathrm{~cm}$ com 8 semanas e o máximo estimado ocorrendo com 20 semanas de crescimento (Figura 4).

A porcentagem de eliminação dos meristemas apicais foi crescente com o máximo estimado ocorrendo por volta de 20 semanas de crescimento. Com 4 e 8 semanas de crescimento foi estimada em 36 e $64 \%$ a eliminação de meristemas apicais, respectivamente (Figura 4). 


$\begin{array}{lcc}\text { NP } & Y=1001-24,8 X & R^{2}=0,53 \\ \text { PMP } & Y=-0,67+0,19 X & R^{2}=0,91 \\ & & n=15 \quad P<0,05\end{array}$

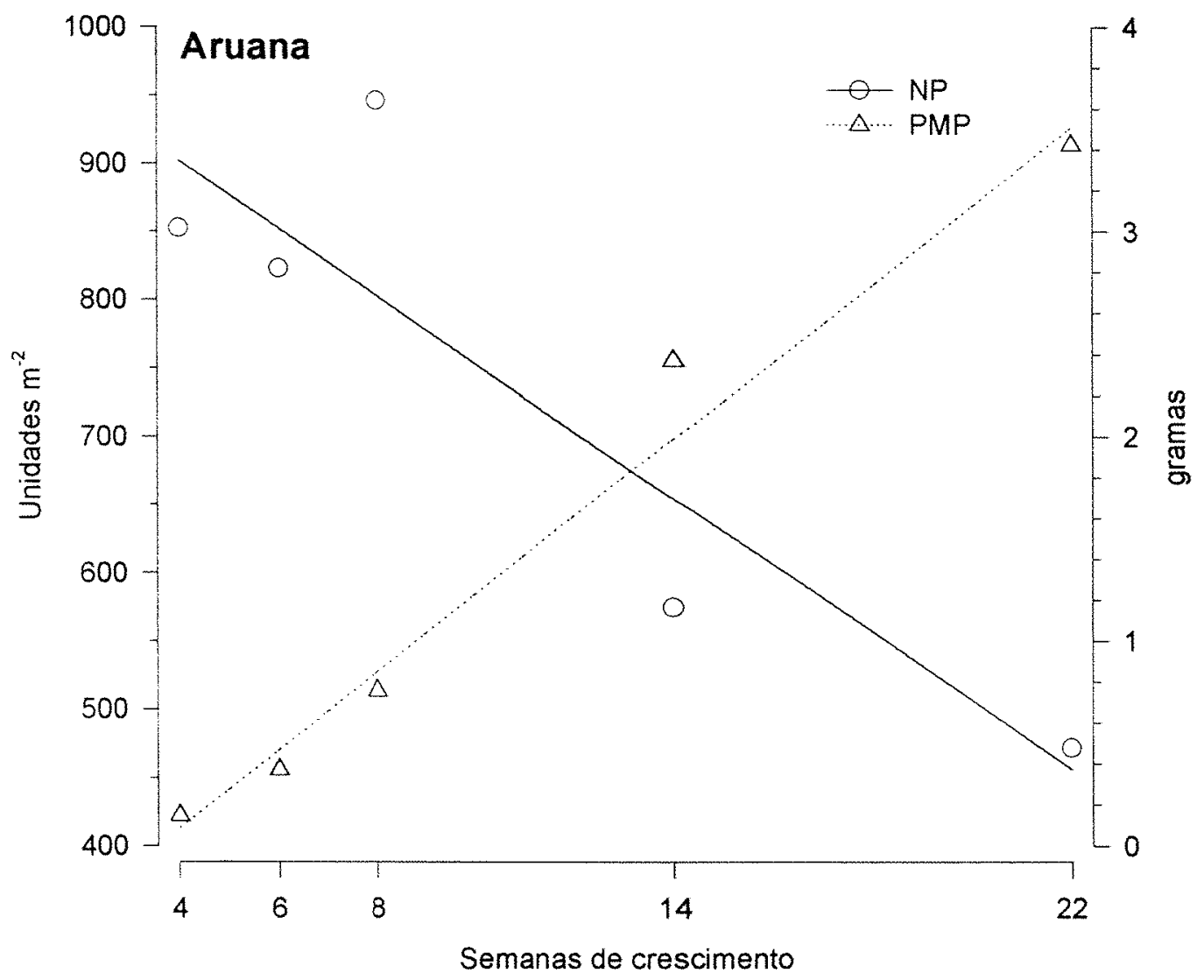

Figura 3. Densidade (NP) e peso médio de perfilhos basais (PMP) do Panicum maximum cultivar Aruana em intervalos de crescimento no inicio da estação chuvosa. Nova Odessa, SP. 

ALT $Y=10,6 X-0,27 X^{2}$
$R^{2}=0,93$
PEMA $Y=9,9 X-0,242 X^{2}$
$\mathrm{R}^{2}=0,91 \quad \mathrm{n}=15$
VR28 $Y=8681-1501 X+67,5 X^{2}$
$\mathrm{R}^{2}=0,91$
$n=12 \quad P<0,05$

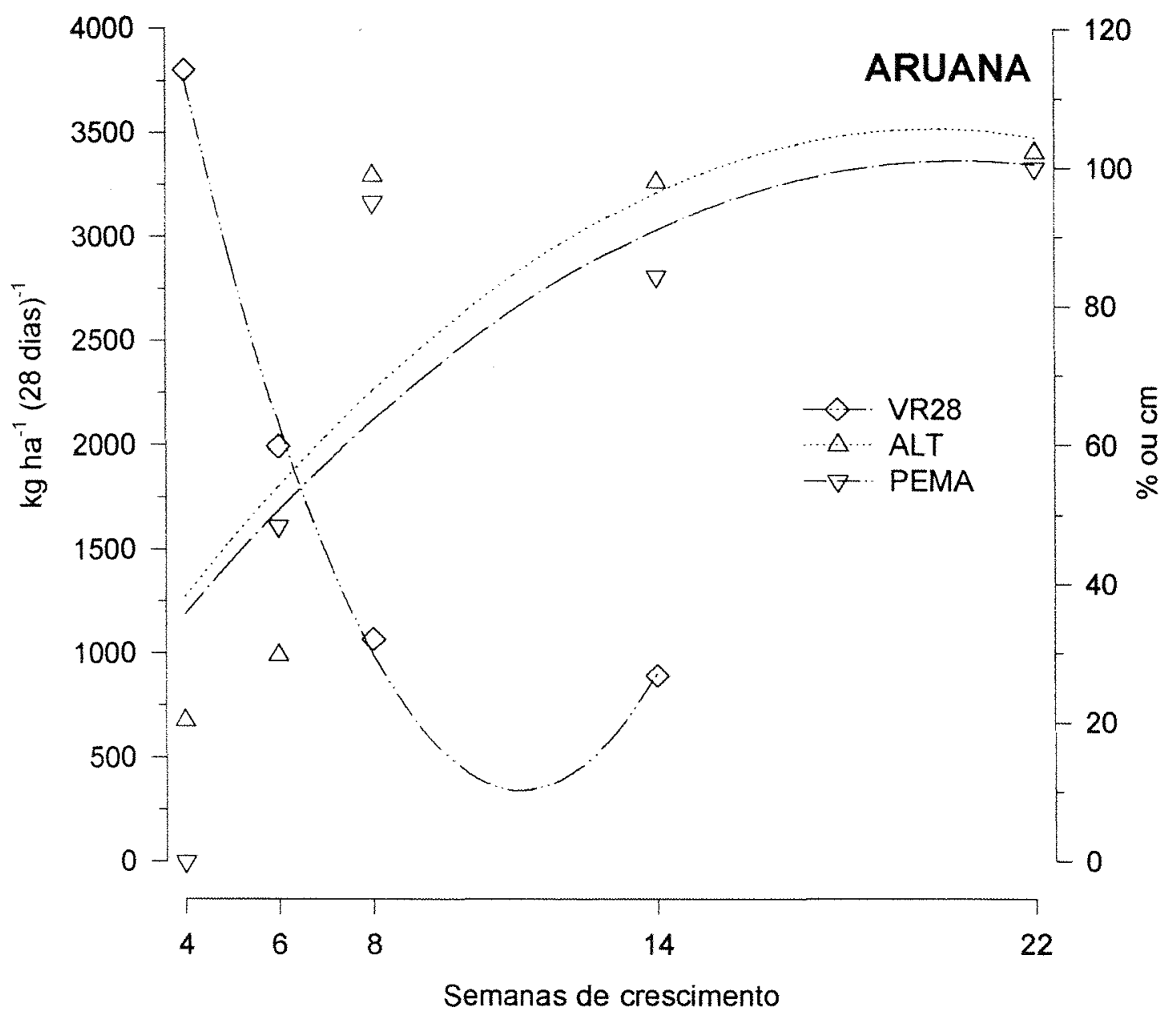

Figura 4. Altura da planta (ALT), porcentagem de eliminação de meristemas apicais de perfilhos basais após o corte (PEMA) e vigor da rebrota (VR28) do Panicum maximum cultivar Aruana em intervalos de crescimento no início da estação chuvosa. Nova Odessa, SP. 
Os modelos polinomiais adotados para as estimativas da altura da planta e da eliminação dos meristemas apicais não representaram de forma satisfatória o comportamento destas variáveis, pois as estimativas indicaram que o máximo valor destas variáveis ocorreria com 20 semanas, ao passo que os valores registrados já tendiam a se estabilizar com 8 semanas de crescimento (Figura 4). Para as médias registradas os modelos que permitiriam melhor estimativa em relação ao observado na figura 4 teriam de incorporar logaritmo [log $(x)$ ou $1 / \log (x)]$ ou raiz quadrada $\left[(x)^{0,5}\right.$ ou $\left.1 /(x)^{0,5}\right]$, sendo que para a altura da planta $(A L T, \mathrm{~cm})$ teríamos $A L T_{4-22}=171$ - 178/In(semanas) - 53/[In(semanas)] ${ }^{2}$, enquanto que para a porcentagem de eliminação de meristemas (PEMA, \%) teríamos $\mathrm{PEMA}_{4-22}=50+323 / \ln$ (semanas) - 546/[In(semanas) $]^{2}$, cuja interpretação biológica é mais complexa. Uma vez que registrou-se a tendência de estabilização com 8 semanas de crescimento, se consideradas apenas as observações entre 4 e 8 semanas seria possível a utilização de modelos polinomiais obtendo-se melhores estimativas. Todavia, os modelos com menor dispersão seriam de terceiro grau, onde teríamos $A L T_{4-8}=28$.semanas $9,5$. semanas $^{2}+0,94$. semanas $^{3}$ e PEMA $_{4-8}=-29$. semanas $+9,3$. semanas $^{2}$ 0,53 . semanas ${ }^{3}$.

O vigor da rebrota, expressado como $\mathrm{kg} \mathrm{ha}^{-1}(28 \mathrm{dias})^{-1}$ apresentou redução em suas médias, à medida que o corte foi efetuado mais tardiamente (Figura 4). A rebrota, inicialmente foi elevada, atingindo $3,8 \mathrm{Mg} \mathrm{ha}^{-1}(28 \mathrm{dias})^{-1}$ (com 4 semanas), mas decresceu rapidamente para 2,0 (com 6 semanas) e 1,0 $\mathrm{Mg} \mathrm{ha}^{-1}$ (28 dias) $^{-1}$ no corte com 8 semanas, mantendo o mesmo patamar de produção de matéria seca após o corte com 14 semanas. Se considerado apenas o período entre 4 e 8 semanas, o decréscimo no vigor da rebrota seria em média de $0,68 \mathrm{Mg} \mathrm{ha}^{-1}$ semana $^{-1}$. As estimativas pelo modelo polinomial para o período entre 8 e 14 semanas não foram adequadas. Para melhores estimativas nesse intervalo novamente os modelos matemáticos teriam de ser mais complexos. $O$ melhor ajuste e a melhor estimativa seriam obtidos pela equação $Y^{0,5}=110-14,9 X+0,654 X^{2}$, onde $Y$ representa o vigor da rebrota, em 
$\mathrm{kg} \mathrm{ha}^{-1}$, e $\mathrm{X} \circ$ intervalo de crescimento, em semanas. Todavia o modelo polinomial adotado mostrou-se adequado para as estimativas entre 4 e 8 semanas, quando o vigor da rebrota mostrou-se mais sensível aos aumentos nos intervalos de crescimento.

A altura do corte adotada $(10 \mathrm{~cm})$ foi abaixo da preconizada por Alcântara et al. (1985) para este cultivar $(20-30 \mathrm{~cm})$ para manejo visando a preservação do meristema apical. Todavia, se considerado o porte baixo que o mesmo apresenta, mesmo com 6 semanas de crescimento o mesmo ainda não seria passível de corte (Tabela 10). Esta recomendação de manejo pode contemplar apenas o aproveitamento em pastejo, pois se imaginarmos a utilização para a produção de feno, a altura do corte acima da adotada neste trabalho não seria viável, pela baixa quantidade de forragem colhida.

Verifica-se que independentemente do ajuste e da dispersão dos modelos matemáticos as médias registradas para a altura da planta e a eliminação de meristemas apicais têm a mesma tendência, indicando a estreita relação entre o crescimento dos perfilhos e a elevação do meristema apical no cultivar Aruana, isto porque precocemente este capim alcançou a fase reprodutiva (Figura 4). A eliminação de meristemas apicais com o crescimento também foi observada por Gomide et al. (1979) para o cultivar Colonião, porém com os maiores valores ocorrendo mais tardiamente em relação ao observado neste trabalho para o cultivar Aruana.

$\mathrm{Na}$ tabela 11 é apresentada a matriz de correlações lineares simples entre os parâmetros agronômicos da produção de matéria seca. Praticamente todas as variáveis foram significativamente $(P<0,05)$ correlacionadas, porém vale ressaltar, algumas correlações comumente avaliadas. Dentre elas, verificou-se que o vigor da rebrota correlacionou-se com a porcentagem de eliminação de meristemas apicais $(r=-0,83 ; P<0,05)$ e com a altura da planta $(r=-0,87 ; P<0,05)$, que em parte reflete a posição relativa do meristema apical. A alta correlação negativa entre o vigor da rebrota e a eliminação de meristemas apicais evidenciou a importância da preservação dos meristemas de modo a 
assegurar a maior quantidade de forragem na rebrota, bem como o efeito do momento da desfolha reduzindo a rebrota subsequente, conforme sugeriram Harris (1981) e Langer (1974). Além da eliminação dos meristemas apicais com o aumento do intervalo de crescimento e face à altura do corte, o resíduo da desfolha tende a apresentar índice de área foliar reduzido, por conta da senescência das folhas inferiores, o que segundo Vickery (1981) influencia na produção da rebrota subsequente.

Da mesma forma que o observado neste trabalho, Gomide et al. (1980) também obtiveram que a eliminação dos meristemas apicais era $\circ$ principal parâmetro afetando negativamente o vigor da rebrota. A produção de forragem na rebrota pelo cultivar Aruana situou-se bem acima da observada por Andrade (1987) para o cultivar Tobiatã $\left(1,2 \mathrm{Mg} \mathrm{ha}^{-1}\right)$ quando o corte foi efetuado com 4 semanas de crescimento, mas semelhante $\left(1,0 \mathrm{Mg} \mathrm{ha}^{-1}\right)$ quando efetuado com 8 semanas de crescimento, porém neste trabalho o cultivar Aruana com 8 semanas já registrava mais de $60 \%$ de seus meristemas apicais eliminados (Figura 4), enquanto o cultivar Tobiatã apresentava o seu meristema apical a 1 $\mathrm{cm}$ do nível do solo.

Face à rápida elevação do meristema apical, o cultivar Aruana foi considerado por Alcântara et al. (1985) como sendo de manejo mais difícil em relação a outros genótipos, isto por que a relação causa-efeito entre eliminação de meristemas e a rebrota ocorre mais precocemente neste cultivar. A partir da observação das informações das figuras 1 e 4 , tem-se que a relação é inversa entre a produção de forragem no primeiro corte na estação de crescimento (MSFOR) com a apresentada pela rebrota após 28 dias (VR28). Considerandose o total produzido no crescimento primário $(4,6,8$ ou 14 semanas) juntamente com o produzido na rebrota de 28 dias (VR28) (Tabela 10), tem-se que o aproveitamento da forragem com 14 semanas permitiria a maior produção (MSFOR+VR28), enquanto que 0 aproveitamento com 4 ou 6 semanas resultaria em rendimentos semelhantes. Com o corte efetuado após 8 semanas, o total produzido seria intermediário ao das demais épocas. $O$ aproveitamento 
após 14 semanas seria pouco provável se considerarmos que em geral há demanda reprimida por volumoso logo após a saída da estação de menor crescimento, além disso há maior participação do material senescido e de colmos (Tabela 10). Nos demais intervalos de crescimento, o total de forragem produzido nos dois cortes (MSFOR+VR28) e o maior rendimento por semana de crescimento seriam para 0 aproveitamento da forragem com 8 semanas e da sua rebrota de 28 dias (633 $\mathrm{kg} \mathrm{ha}^{-1}$ semana ${ }^{-1}$ ). Todavia, para as demais épocas de aproveitamento (4 ou 6 semanas), uma vez adotado um maior período para a rebrota, o rendimento total de forragem poderá ser ampliado, e a taxa média de produção por semana seria superior ao total observado com 8 semanas de crescimento.

Neste cultivar a rápida elevação dos meristemas apicais com o crescimento e a adubação reveste-se de maior importância para a definição da época de aproveitamento da forragem ao início da estação chuvosa, pois o benefício decorrente da adubação com fontes solúveis poderá não se estender aos demais períodos de crescimento se as rebrotas subsequentes forem menos vigorosas. 


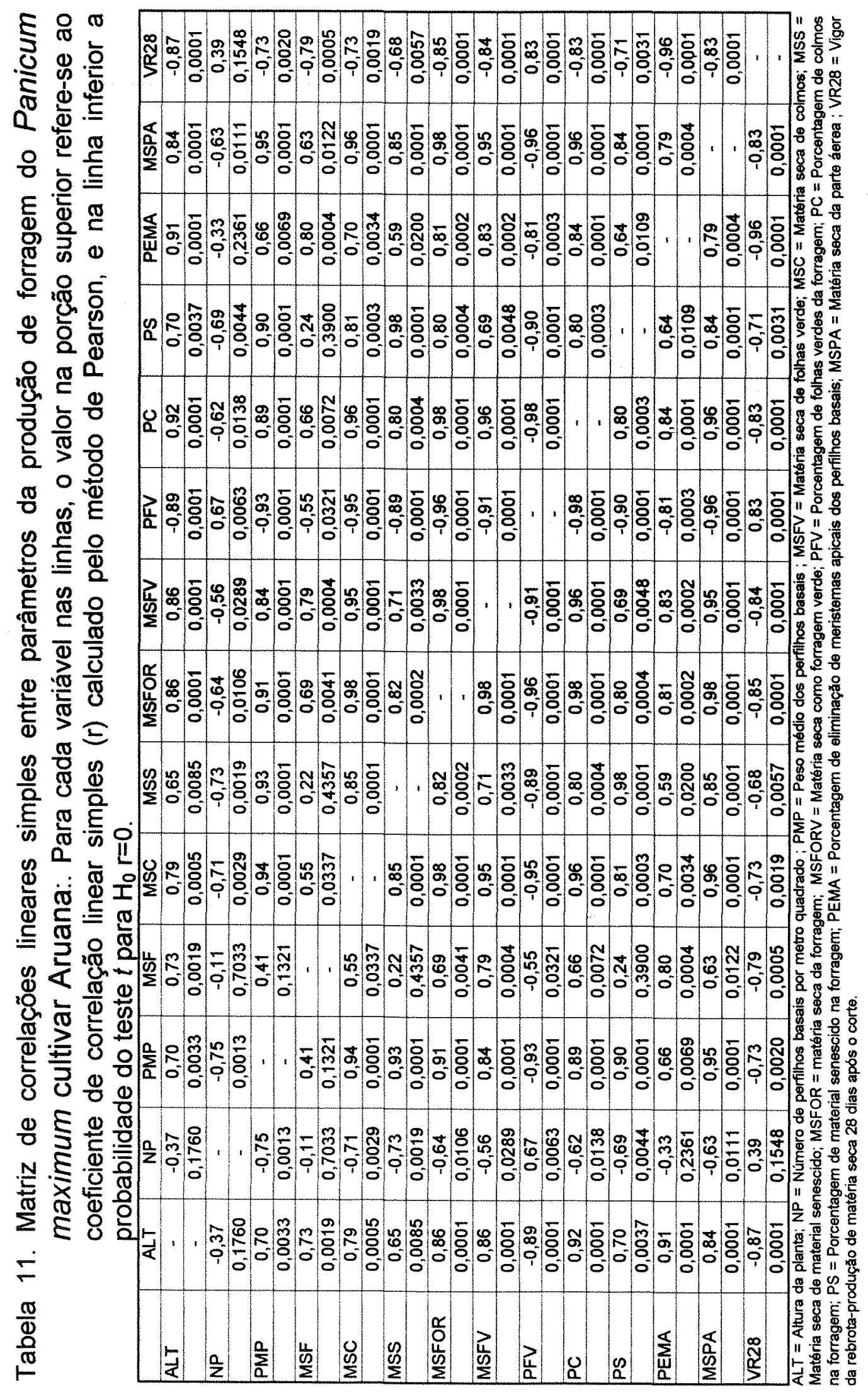




\subsubsection{Panicum maximum cultivar $\mid Z-1$}

As médias originais dos parâmetros agronômicos ligados à produção de matéria seca nos intervalos de crescimento do cultivar IZ-1 são apresentadas na tabela 12.

\subsubsection{Produção de matéria seca da parte aérea}

Na figura 5 é apresentada a produção de matéria seca nos intervalos de crescimento para o cultivar $\mid Z-1$. A produção de matéria seca na parte aérea (corte rente ao solo) e de forragem (corte a $10 \mathrm{~cm}$ do nivel do solo) elevou-se de forma linear com o aumento nos intervalos de crescimento. Na parte aérea e na fração considerada como forragem foram registrados incrementos para cada semana, em média, da ordem de 1,17 e 1,27 Mg ha ${ }^{-1}$, respectivamente (Figura 5). A resposta linear apresentada pela matéria seca da parte aérea deve-se ao fato de que o cultivar IZ-1 não atingiu a fase reprodutiva durante o período de 22 semanas, evidenciando o seu ciclo mais tardio em relação ao cultivar Aruana, avaliado neste trabalho. A produção de matéria seca de forragem com 4 semanas foi de apenas $0,2 \mathrm{Mg} \mathrm{ha}^{-1}$, porém com 6 semanas alcançou $2,1 \mathrm{Mg}$ $\mathrm{ha}^{-1}$, dobrando a sua produção de matéria seca nos períodos entre 6 e 8 , 8 e 14 , e 14 e 22 semanas.

As folhas verdes constituíram a forragem acumulada no intervalo de crescimento entre 4 e 6 semanas. Com 6 semanas a produção de matéria seca de folhas era de $2,1 \mathrm{Mg} \mathrm{ha}^{-1}$ e após 8,14 e 22 semanas foram registradas produções de 4,0; 8,3 e $11,0 \mathrm{Mg} \mathrm{ha}^{-1}$, respectivamente. Em média, para cada semana de crescimento, foram acumuladas $0,6 \mathrm{Mg} \mathrm{ha}^{-1}$ de matéria seca de folhas verdes (Figura 5). 


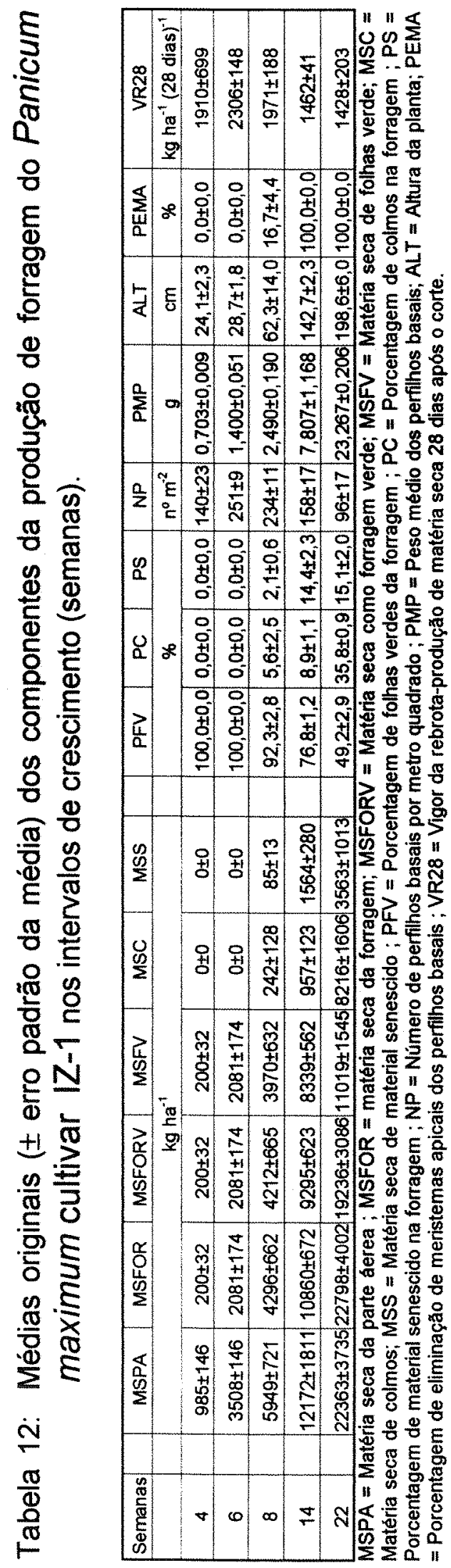




$\begin{array}{llll}\text { MSPA } & Y=-3657+1171 X & R^{2}=0,89 & \\ \text { MSFOR } & Y=-5489+1253 X & R^{2}=0,90 & \\ \text { MSFORV } & Y=-4264+1043 X & R^{2}=0,91 & \\ \text { MSFV } & Y=-1356+599,8 X & R^{2}=0,89 & n=15 \quad P<0,05 \\ \text { MSC } & Y=5594-1119 X+56,3 X^{2} & R^{2}=0,88 & n=9 \quad P=0,07 \\ \text { MSS } & Y=-1907+248,5 X & R^{2}=0,73 & n=9 \quad P<0.05\end{array}$

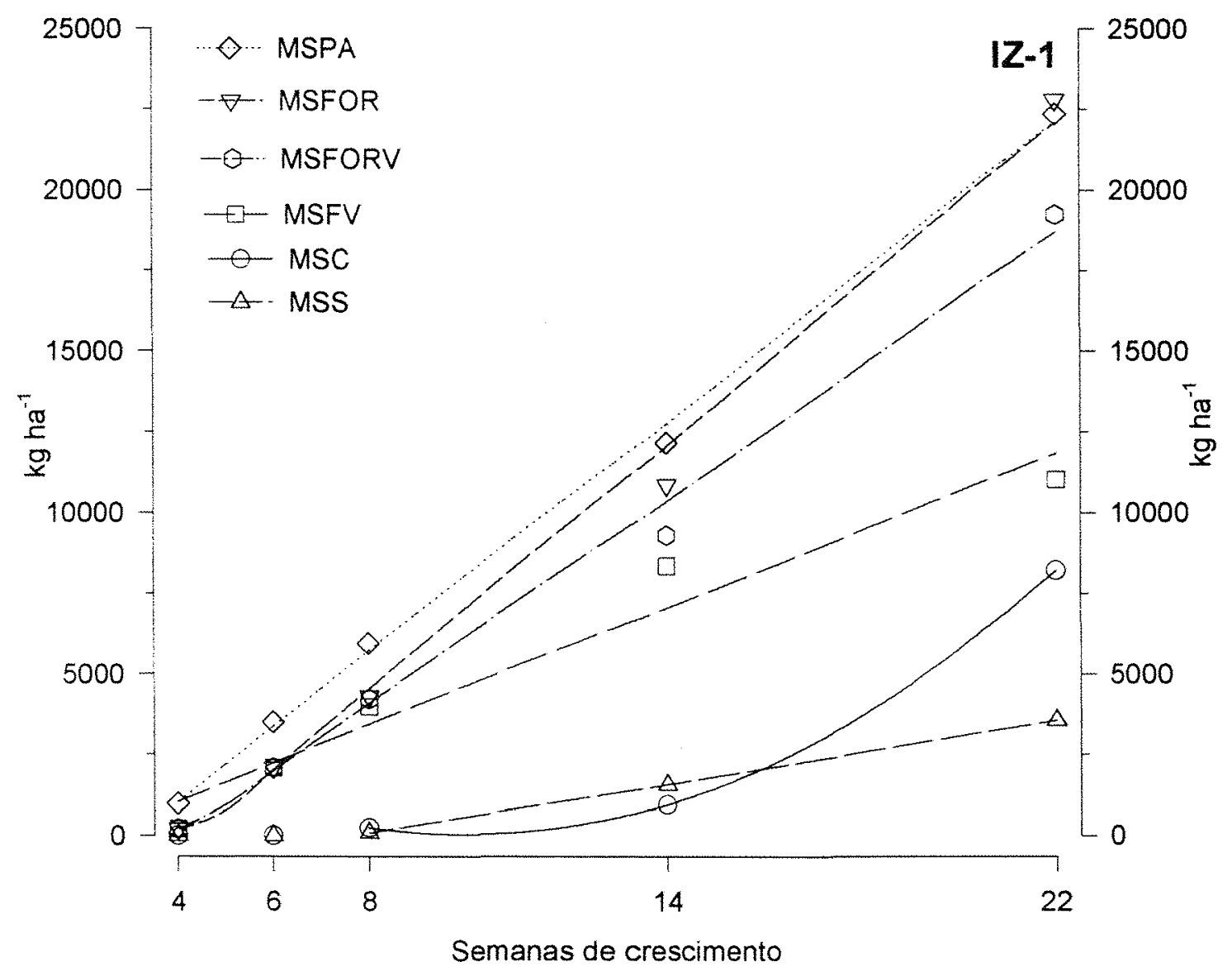

Figura 5. Produção de matéria seca (MS) da parte aérea e de componentes da forragem do Panicum maximum cultivar $\mathrm{Z}-1$ em intervalos de crescimento no início da estação chuvosa. Nova Odessa, SP. 1993/94. MSPA = Parte aérea; MSFOR= Forragem $(>15 \mathrm{~cm}) . M S F O R V=$ Forragem Verde; $M S F V=$ Folhas Verdes; $M S C=$ Colmos; $M S S=$ Material senescido. 
A produção de matéria seca de colmos também foi crescente, mas apenas a partir de 8 semanas esta fração passou a compor a forragem, porém com médias bem reduzidas. Com 8 e 14 semanas o total de colmos produzido foi de 0,24 e $0,96 \mathrm{Mg} \mathrm{ha}^{-1}$. Todavia, com 22 semanas a produção de matéria seca de colmos foi de $8,2 \mathrm{Mg} \mathrm{ha}^{-1}$.

$O$ acúmulo de material senescido na forragem ocorreu a partir da oitava semana de crescimento, equivalendo neste período a cerca de $0,09 \mathrm{Mg} \mathrm{ha}^{-1}$. A partir de então, evoluiu em taxas médias de $0,25 \mathrm{Mg} \mathrm{ha}^{-1}$ semana ${ }^{-1}$, alcançando 1,6 e 3,5 $\mathrm{Mg} \mathrm{ha}^{-1} \mathrm{com} 14$ e 22 semanas, respectivamente.

A produção de matéria seca de forragem verde (folhas + colmos) ocorreu de forma linear crescente, com incrementos médios de $1,04 \mathrm{Mg} \mathrm{ha}^{-1}$ semana $^{-1}$ (Figura 5). Até 8 semanas, a forragem verde alcançou $4,2 \mathrm{Mg} \mathrm{ha}^{-1}$, em grande parte constituida por folhas verdes, e da mesma forma ocorreu após 14 semanas, quando atingiu $9,3 \mathrm{Mg} \mathrm{ha}^{-1}$. Após 22 semanas, 19,2 $\mathrm{Mg} \mathrm{ha}^{-1}$ de forragem verde haviam sido acumuladas.

$\mathrm{Na}$ figura 6 são apresentadas as variações na participação relativa, em peso seco, das folhas verdes, colmos e material senescido. A porcentagem de folhas verdes na forragem decresceu à medida em que aumentou o intervalo de crescimento, ao contrário do registrado para as porcentagens de colmos. A partir da $14^{a}$ semana elevou-se a participação do material senescido, superando a participação dos colmos na forragem. A tendência de estabilização na participação relativa do material senescido após 14 semanas é aparente, pois deveu-se ao incremento na produção de matéria seca da fração colmo, que aumentou em 8,5 vezes a sua produção e elevou a sua participação na forragem em 4 vezes no período entre 14 e 22 semanas.

A baixa produção de forragem apresentada com 4 semanas de crescimento no cultivar $\mathrm{IZ}-1$ foi atípica considerando-se a adubação adotada e o potencial de produção da espécie. Este comportamento deveu-se à conjugação entre a altura do corte, hábito de crescimento da planta logo após a 
desfolha $e$ ao efeito do ambiente. O experimento com este genótipo foi o primeiro a ser instalado, ao final de agosto quando as chuvas aumentaram a sua freqüência. Todavia, da tabela 6 verifica-se que o total pluviométrico para o mês de agosto de 1993 situou-se abaixo da série histórica 1968-1987, e embora no mês de setembro de 1993 tenha se situada acima da série histórica, no período correspondente ao crescimento de 4 semanas, o total pluviométrico registrado foi de apenas $50,8 \mathrm{~mm}$ (Tabela 8 ), correspondendo a apenas $1,81 \mathrm{~mm} \mathrm{dia}{ }^{-1}$, sendo bem abaixo da média verificada para os outros intervalos de crescimento $\left(3,6 \mathrm{~mm} \mathrm{dia}{ }^{-1}\right)$. Além disso, o espaçamento em que este genótipo foi cultivado, definiu um crescimento inicial dos perfilhos de forma menos ereta. Deste modo, com a altura do corte de $15 \mathrm{~cm}$, por conta de seu maior porte, e as condições hídricas menos favoráveis, foram amostradas apenas lâminas foliares neste intervalo de crescimento, refletindo em baixa produção de forragem.

Apesar das condições climáticas iniciais menos favoráveis, com 6 semanas de crescimento a taxa de acúmulo de forragem (49 $\mathrm{kg} \mathrm{ha}^{-1} \mathrm{dia}^{-1}$ ) equivalia à relatada por Pedreira (1972) para o cultivar Colonião em crescimento no mês de outubro, quando a temperatura é mais alta. Para os intervalos de crescimento de 4 e 6 semanas a produção de forragem registrada pelo cultivar IZ-1 $\left(0,2\right.$ e 2,1 $\left.\mathrm{Mg} \mathrm{ha}^{-1}\right)$ foi inferior a obtida por Gomide \& Zago (1980) com o cultivar Colonião, porém com 8 semanas de crescimento a produção registrada não diferiu $\left(4,2 \mathrm{Mg} \mathrm{ha}^{-1}\right.$ ) (Tabela 12). A forragem acumulada com 22 semanas de crescimento superou a obtida no trabalho de Andrade (1987) para o mesmo cultivar e pelo cultivar Tobiatã após 24 semanas.

Chama atenção a participação tardia do material senescido na forragem acumulada, que superou a participação relativa dos colmos entre 8 e 17 semanas de crescimento (Figura 6). A produção de colmos veio a superar a produção de material senescido somente após 16 semanas de crescimento $(2,1$ $\mathrm{Mg} \mathrm{ha}^{-1}$ ), quando a matéria seca de folhas já alcançava $8,2 \mathrm{Mg} \mathrm{ha}^{-1}$ (Figura 5). A participação tardia do material senescido na forragem amostrada também foi observada no trabalho de Andrade (1987) para o cultivar IZ-1 (após 20 semanas). 


$\begin{array}{lll}\text { PFV } & Y=107-1,3 X-0,06 X^{2} & R^{2}=0,97 \\ \text { PC } & Y=3,3-1,05 X+0,114 X^{2} & R^{2}=0,96 \\ \text { PS } & Y=9,9-4,5 X+0,57 X^{2}-0,0161 X^{3} & R^{2}=0,92 \\ & & n=15 P<0,05\end{array}$

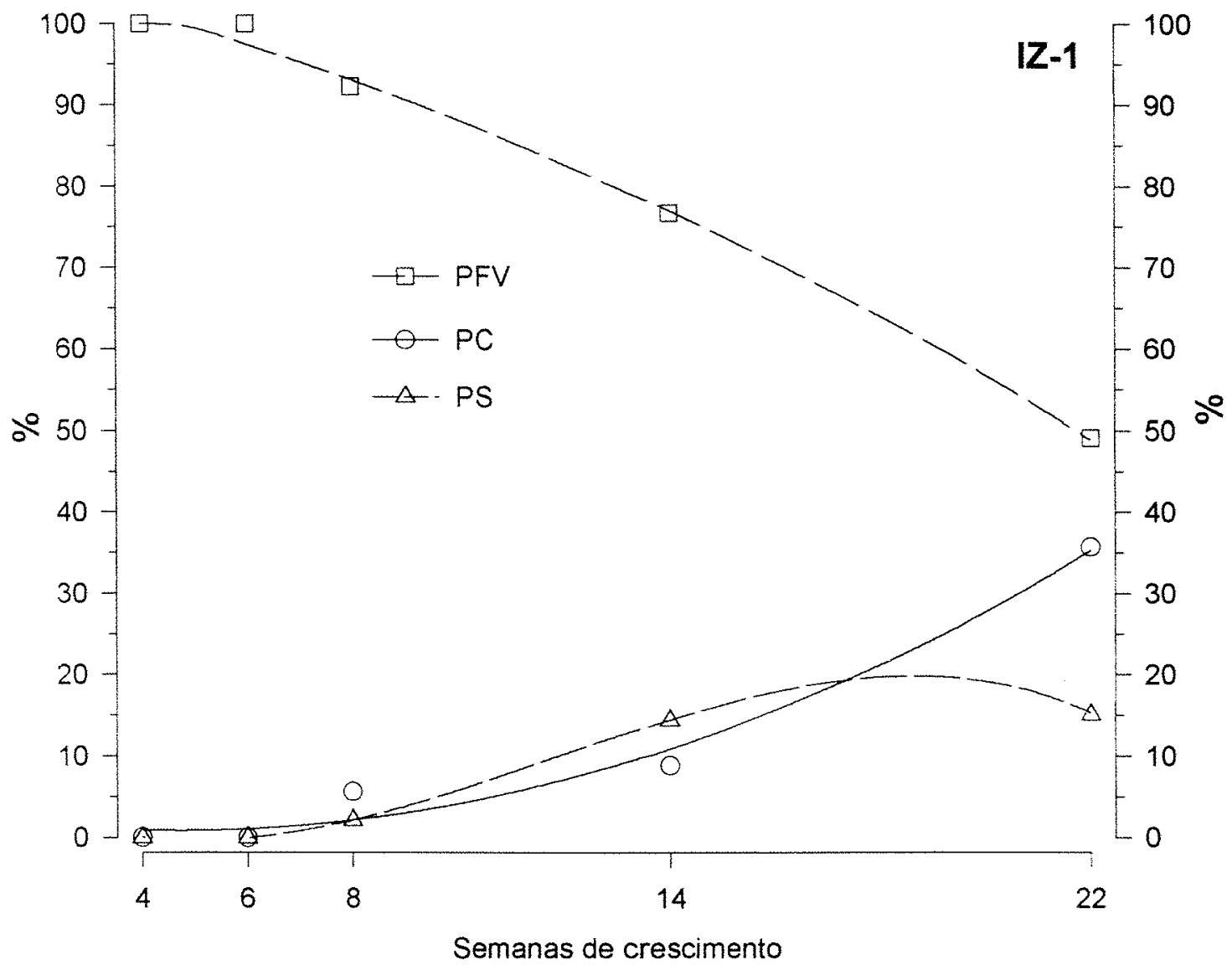

Figura 6. Porcentagem de folhas verdes (PFV), colmos (PC) e material senescido (PS) na forragem acumulada pelo Panicum maximum cultivar IZ-1 em intervalos de crescimento no início da estação chuvosa. Nova Odessa, SP. 
$O$ acúmulo de forma linear da forragem na pastagem do cultivar $I Z-1$, bem como da matéria seca de folhas e do material senescido, e a elongação mais tardia das hastes frente à adubação possibilitam, considerando-se apenas o aspecto agronômico, maior espaço de tempo para o acúmulo de forragem até que seja efetuado o seu aproveitamento. Até 14 semanas, $78 \%$ da forragem produzida era constituída de folhas verdes, o que representa alta densidade de folhas na pastagem $\left(58 \mathrm{~kg} \mathrm{ha}{ }^{-1} \mathrm{~cm}^{-1}\right)$, permitindo maior capacidade para a seleção e preensão desta fração pelo animal em pastejo conforme evidenciou o trabalho de Stobbs (1973b). A elevada capacidade de produção de folhas do cultivar IZ-1 torna-se mais evidente quando comparada a disponibilidade de folhas com 8 semanas de crescimento $\left(4,0 \mathrm{Mg}\right.$ ha $\left.{ }^{1}\right)$ em relação à produção anual de folhas descrita por Jank (1994) para cinco cultivares de Panicum maximum (2,8 a 5,2 $\left.\mathrm{Mg} \mathrm{ha}^{-1}\right)$.

$O$ aproveitamento da forragem do cultivar $\mathrm{Z}-1$ com até 16 semanas de crescimento está sob maior influência do material senescido, uma vez que a sua disponibilidade na pastagem é maior que a dos colmos. O processo de senescência das folhas no cultivar IZ-1 instalou-se mais tardiamente (após 8 semanas), porém o mesmo reveste-se de importância pela elevada taxa de acúmulo do material senescido a qual não atinge maior expressão graças à elevada taxa de acúmulo de folhas na forragem. Neste trabalho o material senescido acumulado com 10, 12 e 14 semanas de crescimento alcançou 0,6, 1,1 e $1,6 \mathrm{Mg} \mathrm{ha}^{-1}$ no cultivar $\mathrm{Z}-1$, respectivamente, enquanto que para o cultivar Aruana, de ciclo mais precoce, registrou o acúmulo de $0,5, \quad 0,8$ e 1,3 $\mathrm{Mg}$ nos mesmos intervalos de crescimento, ou seja, em termos absolutos as perdas de forragem por senescência são maiores no cultivar $\mid Z-1$. $O$ aproveitamento da forragem com até 8 semanas de crescimento seria 0 ideal, pois a perda de forragem por senescência seria praticamente nula, todavia a disponibilidade de forragem ainda seria muito baixa levando-se em conta a quantidade de fertilizantes aplicada. 
Face às condições menos favoráveis ao crescimento inicial, e considerando a alta quantidade e proporção de folhas na forragem, o aproveitamento da forragem pode ocorrer mesmo após 14 semanas.

\subsubsection{Perfilhos}

O número e o peso médio dos perfilhos basais em intervalos de crescimento da pastagem do cultivar $1 \mathrm{Z}-1$ são apresentados na figura 7 . A densidade de perfilhos após 4 semanas mostrou-se em elevação, com a maior média registrada com 6 semanas (251 unidades $\mathrm{m}^{-2}$ ), sendo 4 semanas antes da estimada pelo modelo (10 semanas), isto por conta do perfilhamento observado após 4 semanas de crescimento que afetou o ajuste do modelo polinomial. Considerando-se apenas o período compreendido entre 6 e 22 semanas, a mortalidade líquida de perfilhos seria, em média, de 10 unidades $\mathrm{m}$ 2. Com a mortalidade dos perfilhos, após 14 semanas a densidade de perfilhos foi próxima da registrada com 4 semanas, atingindo cerca de 100 unidades $\mathrm{m}^{-2}$ após 22 semanas de crescimento.

$O$ incremento na densidade de perfilhos entre 4 e 6 semanas de crescimento não representa o padrão em se tratando de perfilhos basais, uma vez que o estímulo ao perfilhamento é mais concentrado nesta espécie conforme relatou Corsi (1986), além disso segundo Langer (1963) a adubação nitrogenada também reduz a duração do período de perfilhamento. $O$ fato do capim IZ-1 ter sido estabelecido num espaçamento maior que o convencional para o seu cultivo, propiciaria perfilhamento mais intenso conforme descreveu Ludlow (1978), o que no tempo também acarretaria maior concentração do perfilhamento. Todavia, este comportamento divergente pode decorrer do estresse hídrico inicial a que as plantas foram submetidas em relação aos demais períodos de crescimento, o qual não deve ter permitido 0 desenvolvimento das gemas de modo concentrado ou ocasionado a morte dos perfilhos mais débeis surgidos no período anterior a 4 semanas $e_{\text {.. }}$ 
posteriormente, com as condições climáticas (chuva e temperatura) mais favoráveis o balanço entre a mortalidade e o aparecimento dos perfilhos permitiu a elevação da densidade dos mesmos entre 4 e 6 semanas (Figura 7). A mortalidade experimentada após 8 semanas também pode ser atribuída à competição por luz que segundo Ludlow (1978) é mais marcante quando não é concentrado o perfilhamento.

Com o crescimento, de forma lógica o peso médio dos perfilhos basais elevou-se, passando de $0,7 \mathrm{~g}$ (com 4 semanas) para $23 \mathrm{~g}$ (com 22 semanas), o que representou um aumento no peso de $1,25 \mathrm{~g}$ por perfilho (Figura 7 ). Neste trabalho o peso médio dos perfilhos foi superior ao relatado por Andrade (1987) para os cultivares $\mathrm{IZ}-1$, Tobiatã e o genótipo $\mathrm{K}-187 \mathrm{~B}$, sendo que com 24 semanas de crescimento o cultivar IZ-1 apresentava perfilhos com $8,5 \mathrm{~g}$, cerca de $1 / 3$ do peso registrado neste experimento após 22 semanas. Porém, a densidade de perfilhos foi 5 e 2 vezes menor que a relatada por Andrade (1987) após 4 e 8 semanas de crescimento, respectivamente, para este mesmo cultivar. O cultivar IZ-1 apresenta menor densidade de perfilhos em relação a outros cultivares do mesma espécie, como puderam registrar Alcântara et al. (1991), mas neste trabalho a menor densidade e o maior peso decorreram do espaçamento entre as linhas do cultivar $I Z-1$, que foi 4 vezes superior ao adotado por Andrade (1987), tornando mais evidente a relação inversa entre o peso e a densidade de perfilhos basais, também observada no experimento com o cultivar Aruana neste trabalho. Ao contrário do observado por Jolliffe et al. (1990), a produtividade do cultivar IZ-1 não foi afetada ou condicionada pela densidade de plantas uma vez que o alto peso dos perfilhos pôde compensá-la.

Pode-se inferir, a partir da redução da densidade de perfilhos com o aumento no intervalo de crescimento, que a desfolha efetuada mais precocemente possibilita a ocorrência de maior densidade de perfilhos. Neste trabalho a densidade de perfilhos seria superior à registrada com 4 semanas de crescimento por até 19 semanas de crescimento (Figura 7). 


$$
\begin{array}{llc}
\text { NP } & Y=139+15,2 X-0,79 X^{2} & R^{2}=0,53 \\
\text { PMP } & Y=1,73-0,47 X+0,066 X^{2} & R^{2}=0,99 \\
& & n=15 \quad P<0,05
\end{array}
$$

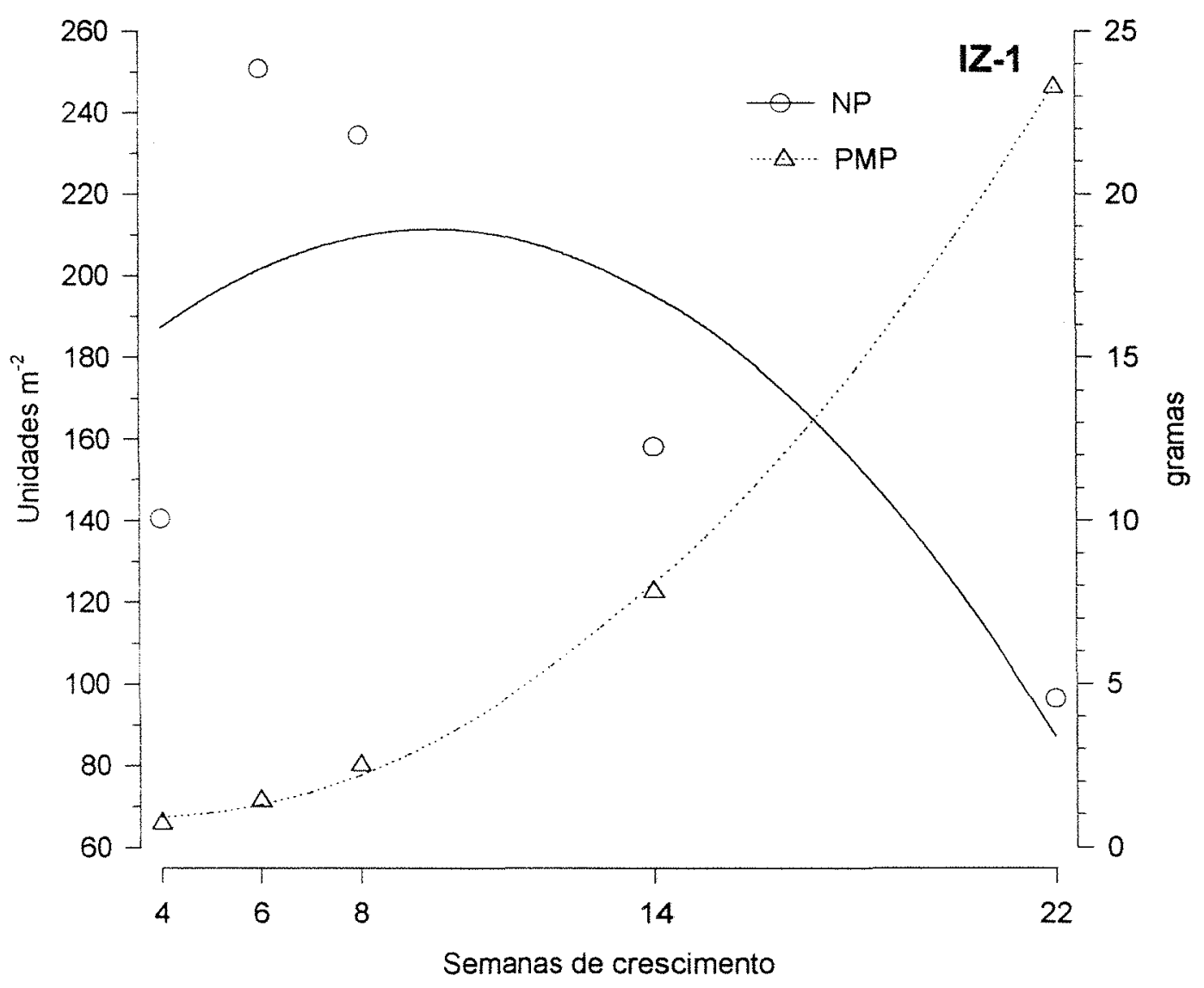

Figura 7. Densidade (NP) e peso médio de perfilhos basais (PMP) do Panicum maximum cultivar $\mathrm{IZ}-1$ em intervalos de crescimento no início da estação chuvosa. Nova Odessa, SP. 
Quando comparada com outras pastagens deste mesmo cultivar estabelecidas no Instituto de Zootecnia, verificou-se que o maior peso dos perfilhos neste trabalho relacionou-se com o aumento nas dimensões das folhas e do diâmetro do colmo. A participação dos colmos na forragem também foi tardia, e embora o acúmulo de forragem e de folhas tenha ocorrido de forma linear, o diâmetro do colmo ofereceria limitações ao seu aproveitamento como forragem nos maiores intervalos de crescimento, além disso indiretamente afetaria o aproveitamento das folhas verdes, especialmente após 14 semanas de crescimento.

4.1.2.3. Eliminação de meristemas apicais e vigor da rebrota

A figura 8 ilustra o comportamento produtivo do cultivar $\mathrm{Z}-1$, como vigor da rebrota, após o corte nos intervalos de crescimento. Também são apresentadas a altura das plantas e a porcentagem de eliminação dos meristemas apicais dos perfilhos basais.

As plantas do cultivar IZ-1 elevaram a sua altura de forma linear com o aumento no intervalo de crescimento, numa taxa média de $10,4 \mathrm{~cm}$ semana ${ }^{-1}$, de tal modo que as mesmas apresentaram $29 \mathrm{~cm}$ de altura com 6 semanas, e alcançaram 62, 143 e $199 \mathrm{~cm}$ com 8, 14 e 22 semanas, respectivamente.

A porcentagem de eliminação dos meristemas apicais elevou-se de forma quadrática entre 6 e 22 semanas (Figura 8). O máximo valor estimado pelo modelo superaria o limite de $100 \%$, e ocorreria com 18 semanas de crescimento. A eliminação dos meristemas apicais só passou a ocorrer após 8 semanas, sendo baixa (17\%) e chegou a $100 \%$ após 14 semanas. O longo intervalo de 6 semanas entre as avaliações sucessivas não permitiu definir melhor os incrementos na eliminação de meristemas. Neste experimento a altura da planta com 12 semanas de crescimento foi estimada em 1,0 m, enquanto que no trabalho de Andrade (1987) o cultivar IZ-1 apresentou altura de $1,3 \mathrm{~m}$ e tinha o seu meristema apical situado a $23 \mathrm{~cm}$ do nível do solo, não 
ocorrendo a sua elevação de forma linear com o tempo ou com a altura da planta. Considerando-se que o cultivar IZ-1 apresenta ciclo tardio, é pouco provável que a eliminação de meristemas apicais neste trabalho tenha atingido o valor máximo antes de 12 semanas de crescimento.

A análise de regressão indicou apenas a tendência de diminuição no vigor da rebrota $(P=0,12)$ com o aumento no intervalo de crescimento. Para os intervalos de crescimento avaliados a rebrota foi de $1,82 \pm 0,37 \mathrm{Mg} \mathrm{ha}^{-1}$ (28 dias) 1 (Figura 8), estando situada acima das médias registradas por Andrade (1987), provavelmente porque adotaram menores alturas do corte $(10 \mathrm{~cm})$.

Pela análise da tabela 13 ainda pode-se verificar a correlação linear simples entre o vigor da rebrota e a porcentagem de eliminação dos meristemas apicais $(r=-0,53 ; P=0,04)$. Este valor situa-se abaixo do obtido por Gomide et al. (1979) podendo indicar menor dependência dos meristemas apicais para a rebrota.

O comportamento da rebrota do cultivar IZ-1 permitiria ampliar ainda mais o intervalo para a primeira desfolha na estação de crescimento. A estimativa da ocorrência de plantas com altura de 1,6 m, admissível para aproveitamento da forragem por bovinos, ocorreria por volta de 17,3 semanas, que também de forma estimada equivaleria a $9,0 \mathrm{Mg} \mathrm{ha}^{-1}$ de matéria seca de folhas verdes. Considerando-se apenas a disponibilidade de folhas verdes, o aproveitamento após 14 semanas seria possível, mas havendo maior perda de forragem com o pastejo conforme observou Hilleshein (1989) em pastagens de capim-elefante com maior disponibilidade de forragem e pela estrutura da pastagem como relatou Forbes (1988). Também, se efetuado o mesmo exercício adotado para o cultivar Aruana, considerando-se desta vez a apenas a produção de folhas verdes nos intervalos de crescimento (em função do diâmetro dos colmos) mais o total da rebrota de 28 dias, tem-se que a eficiência na produção de forragem no tempo, tende a diminuir após 14 semanas de crescimento. Deste modo, considerando-se o comportamento produtivo, o aproveitamento da forragem no crescimento inicial poderá ocorrer entre 6 e 14 semanas de crescimento . 


$\begin{array}{lllll}\text { ALT } & Y=-20,5+10,4 X & R^{2}=0,95 & n=15 & \\ \text { PEMA } & Y=-147+27,89 X-0,755 X^{2} & R^{2}=0,97 & n=12 & P<0,05 \\ \text { VR28 } & Y=1816 \pm 370 & & n=15 & P=0,12\end{array}$

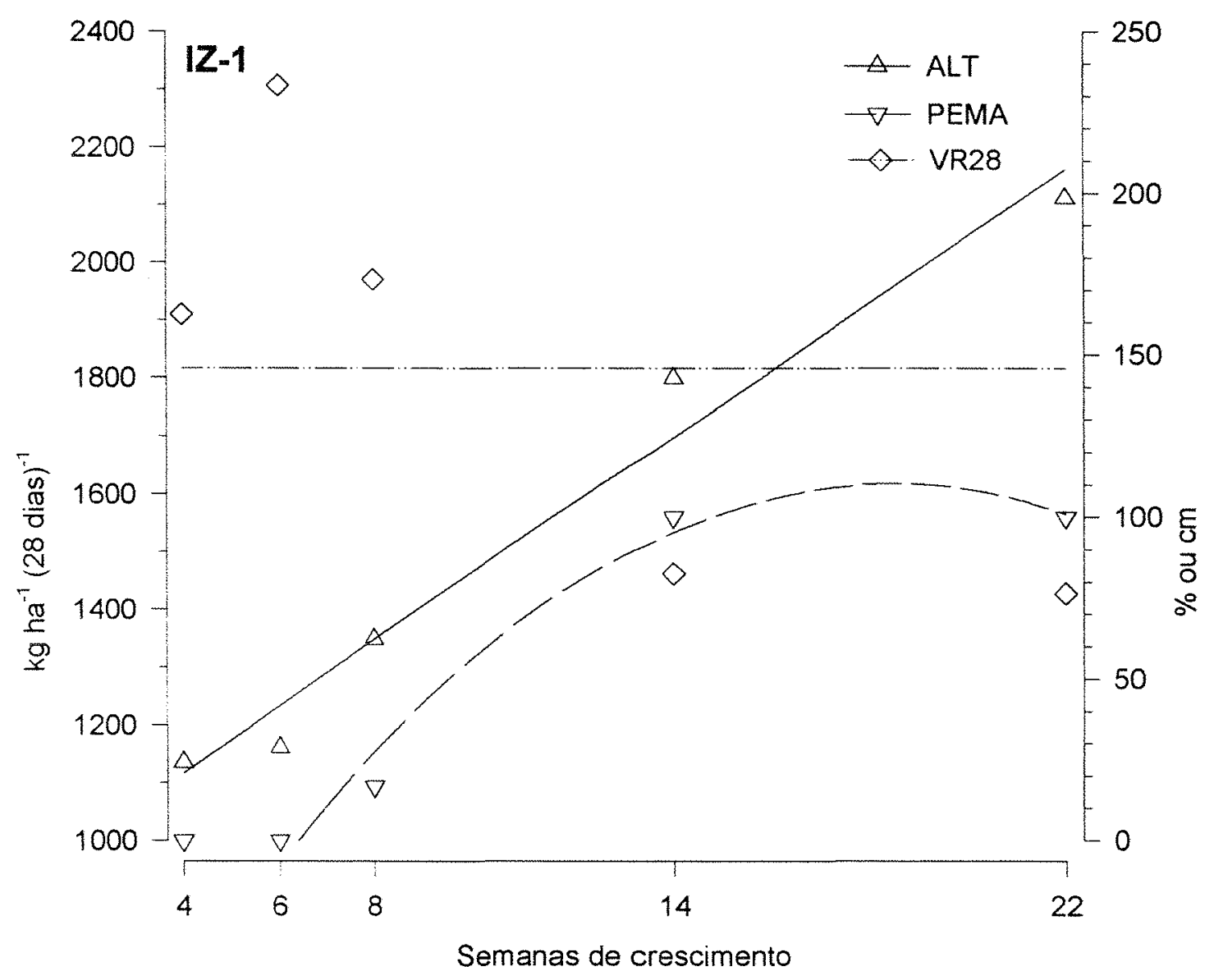

Figura 8. Altura da planta (ALT), porcentagem de eliminação de meristemas apicais de perfilhos basais após o corte (PEMA) e vigor da rebrota (VR28) do Panicum maximum cultivar IZ-1 em intervalos de crescimento no início da estação chuvosa. Nova Odessa, SP. 


\subsubsection{Paspalum coryphaeum NO 174}

As médias originais dos parâmetros agronômicos ligados à produção de matéria seca em intervalos de crescimento do Paspalum coryphaeum NO 174 são apresentadas na tabela 14 .

\subsubsection{Produção de matéria seca da parte aérea}

Na figura 9 é ilustrado o comportamento do Paspalum coryphaeum em crescimento livre de desfolhas. O acúmulo de matéria seca na parte aérea (corte rente ao solo) e da fração considerada como forragem (corte a $10 \mathrm{~cm}$ do nivel do solo) ocorreu de forma linear nos intervalos de crescimento. Para a matéria seca da parte aérea o incremento foi em média de $1,25 \mathrm{Mg} \mathrm{ha}^{-1}$ para cada semana de crescimento, enquanto que para a matéria seca de forragem foi de $0,85 \mathrm{Mg} \mathrm{ha}^{-1}$. Na parte aérea o acúmulo de matéria seca variou de $1,97 \mathrm{Mg}$ $h^{-1}$ (com 4 semanas) a $23,77 \mathrm{Mg} \mathrm{ha}^{-1}$ (com 22 semanas), enquanto que para a forragem variou de 1,8 (com 4 semanas) a $17,4 \mathrm{Mg} \mathrm{ha}^{-1}$ (com 22 semanas) (Figura 9). O acúmulo de matéria seca da parte aérea de forma linear para os intervalos de crescimento deveu-se à duração da fase vegetativa do Paspalum coryphaeum NO 174, sendo que no corte efetuado com 22 semanas de crescimento as plantas apenas haviam cessado a emissão de inflorescências. Após este período ainda poderá ocorrer acúmulo de matéria seca em decorrência do desenvolvimento dos cariopses ou de perfilhamento aéreo, porém deve ser de pequena magnitude, sendo que a tendência é a estabilização na produção. Não se verificou alteração na duração da fase vegetativa nas áreas adjacentes que não foram adubadas em relação as parcelas que foram adubadas. 


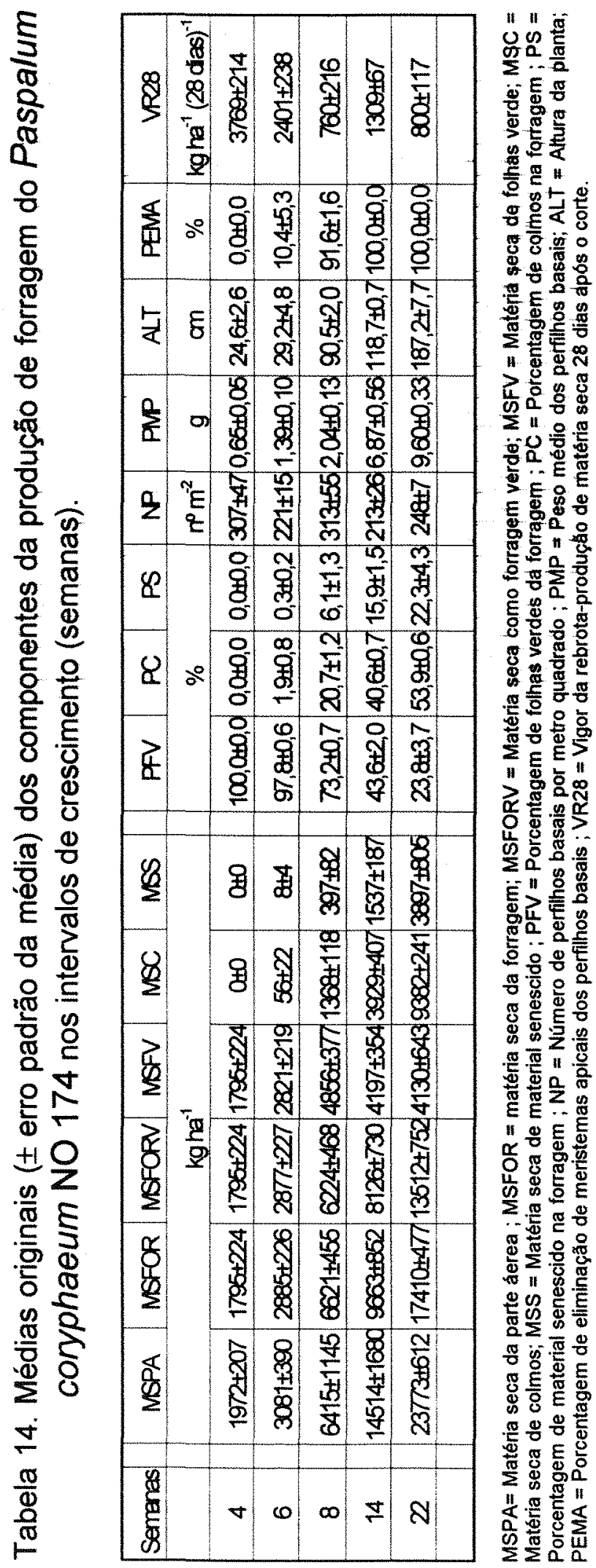




$\begin{array}{llll}\text { MSPA } & Y=-3576+1252 X & R^{2}=0,97 & \\ \text { MSFOR } & Y=-1527+852 X & R^{2}=0,97 & \\ \text { MSFORV } & Y=-289+629 X & R^{2}=0,94 & \\ \text { MSFV } & Y=-140+659 X-21,4 X^{2} & R^{2}=0,55 & n=15 \\ \text { MSC } & Y=-3454+571 X & R^{2}=0,98 & n=12 \\ \text { MSS } & Y=-1563+242 X & R^{2}=0,86 & n=12 \quad P<0.05\end{array}$

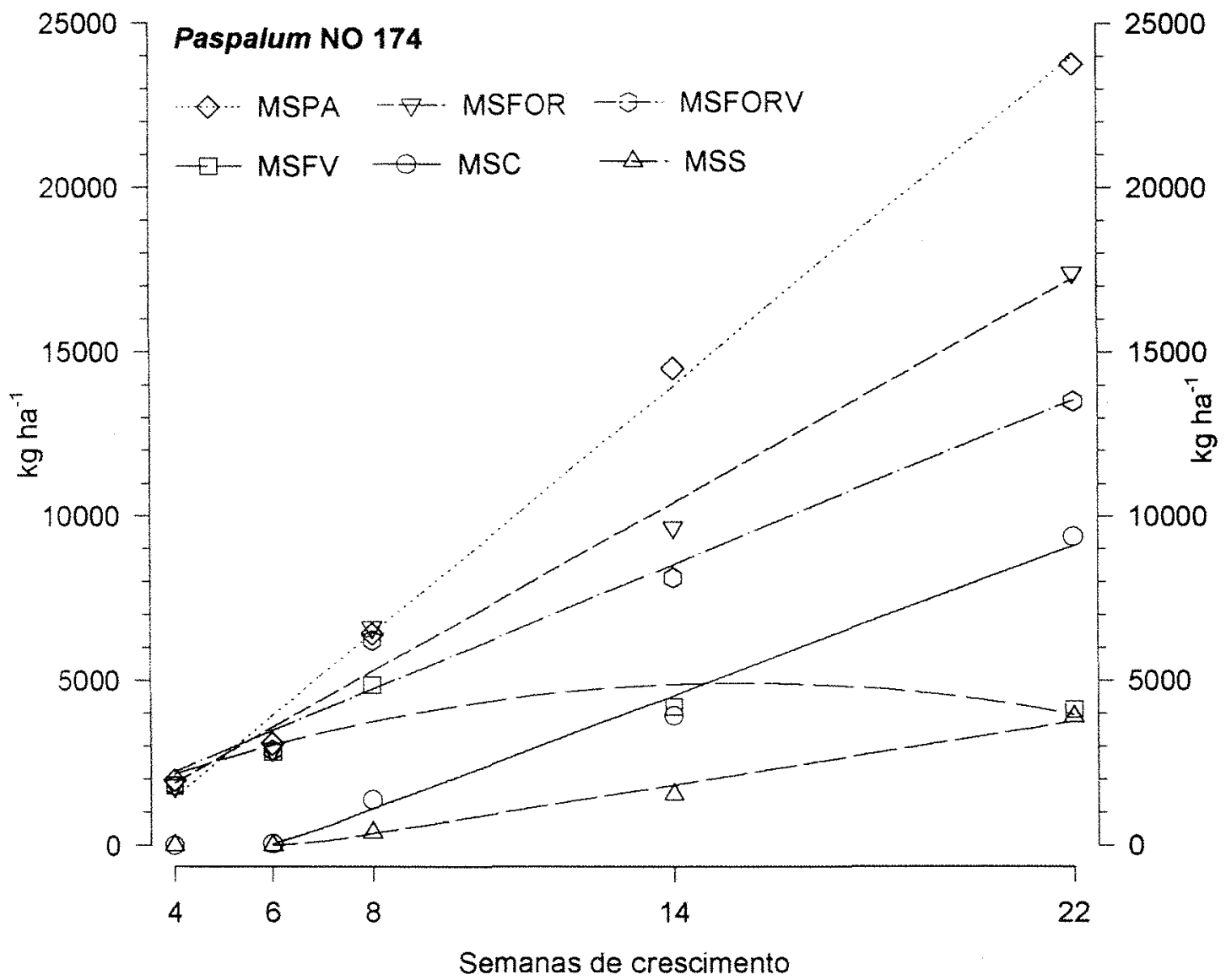

Figura 9. Produção de matéria seca (MS) da parte aérea e de componentes da forragem do Paspalum coryphaeum NO 174 em intervalos de crescimento no início da estação chuvosa. Nova Odessa, SP. 1993/94. MSPA=Parte aérea; MSFOR=Forragem $(>10$ $\mathrm{cm}) . \quad M S F O R V=$ Forragem Verde; MSFV = Folhas Verdes; $M S C=$ Colmos; $M S S=$ Material senescido. 
Exceto para matéria seca de folhas verdes, cuja resposta foi quadrática, as demais frações que compunham a forragem apresentaram resposta linear ao aumento nos intervalos de crescimento. A produção de matéria seca de folhas verdes foi de $1,8 \mathrm{Mg} \mathrm{ha}^{-1}$ após 4 semanas, com a máxima produção de matéria seca estimada ocorrendo por volta de 15 semanas $\left(4,9 \mathrm{Mg} \mathrm{ha}^{-1}\right)$. Todavia a maior média registrada $\left(4,9 \mathrm{Mg} \mathrm{ha}^{-1}\right)$ ocorreu mais precocemente, com 8 semanas (Figura 9). O grande intervalo de tempo entre o máximo estimado e 0 registrado para a matéria seca de folhas decorre do menor ajuste apresentado pelo modelo matemático utilizado. Alguns modelos matemáticos alternativos foram testados para a produção de matéria seca de folhas verdes (MSFV), sendo que o representado pela equação $\ln (\mathrm{MSFV})=4,74+0,92$ semanas 0,0702 .semanas ${ }^{2}+0,00162$. semanas $^{3}$ permitiu maior coeficiente de determinação ajustado $\left(R^{2}=0,65\right)$ e menores desvios para as estimativas, com a máxima produção de folhas estimada ocorrendo por volta de 10 semanas, ou seja mais próximo do valor registrado ( 8 semanas) em relação à estimada pelo polinômio apresentado na figura 9 . Todavia, a interpretação biológica do modelo seria mais complexa.

Nas estimativas dos coeficientes dos polinômios para a matéria seca de colmos e do material senescido foram tomadas apenas as observações relativas aos intervalos de crescimento superiores a 6 semanas, visto que a contribuição destas frações era nula com 4 semanas de crescimento e o ajuste do modelo não era favorecido com a inclusão das mesmas. A produção de matéria seca de colmos registrada foi baixa até 6 semanas $\left(<0,1 \mathrm{Mg} \mathrm{ha}^{-1}\right)$, porém com 8 semanas já equivalia a $1,4 \mathrm{Mg} \mathrm{ha}^{-1}$, alcançando $3,9 \mathrm{Mg}$ ha $^{-1}$ após 14 semanas, e $9,4 \mathrm{Mg} \mathrm{ha}^{-1}$ com 22 semanas. Em média, o acúmulo de colmos deu-se numa taxa de $0,57 \mathrm{Mg} \mathrm{ha}^{-1}$ semana $^{-1}$ no período entre 6 e 22 semanas. $O$ acúmulo de material senescido, também ocorreu de forma linear para o mesmo período, sendo que o incremento médio foi de $0,24 \mathrm{Mg} \mathrm{ha}^{-1}$ semana $^{-1}$. A produção de matéria seca de material senescido foi de 0,$4 ; 1,5$ e 3,9 $\mathrm{Mg} \mathrm{ha}^{-1}$ após 8,14 e 22 semanas, respectivamente. 
A forragem verde (folhas+colmos), por sua vez passou a diferir, em média, da forragem produzida, a partir da $14^{\mathrm{a}}$ semana, quando alcançou $8,1 \mathrm{Mg}$ ha ${ }^{-1}$. Com 22 semanas, em média a produção de matéria seca foi de $13,5 \mathrm{Mg}$ $\mathrm{ha}^{-1}$, sendo definida em grande parte pela produção de matéria seca de colmos. $O$ incremento na matéria seca desta fração foi de $0,63 \mathrm{Mg} \mathrm{ha}^{-1}$ semana $^{-1}$.

A figura 10 permite visualizar a contribuição relativa, em peso, das folhas verdes, colmos e material senescido no total de forragem disponível. As folhas verdes reduziram a sua participação na forragem logo após 4 semanas de crescimento, sendo de forma mais acentuada após 6 semanas, quando passaram a ter lugar a produção de colmos e a senescência das folhas. Com 14 semanas a participação das folhas na forragem era de $43 \%$, alcançando apenas $23 \%$ com 22 semanas. A porcentagem de colmos na forragem foi estimada para o intervalo entre 6 e 22 semanas, visto que a participação era nula com 4 semanas de crescimento. Com até 6 semanas de crescimento a porcentagem de colmos foi inferior a $2 \%$, elevando-se 2 semanas depois para $21 \%$. Após 14 semanas já representava $41 \%$ da forragem produzida, atingindo $54 \%$ do total com 22 semanas. Por sua vez, o material senescido teve sua participação relativa em elevação nos períodos de crescimento, com maior expressão a partir de 14 semanas, quando representou $16 \%$ da forragem acumulada. A porcentagem de material senescido, em média, aumentou 1,33\% para cada semana de crescimento.

O Paspalum coryphaeum NO 174 apresentou, ao longo do período de 22 semanas, produções de forragem superiores àquelas obtidas por cultivares estabelecidos no mesmo espaçamento. As produções de forragem variando de 1,8 e $6,6 \mathrm{Mg} \mathrm{ha}^{-1} \mathrm{com} 4$ e 8 semanas de crescimento (Figura 9 e Tabela 14) foram superiores àquelas relatadas para três cultivares de Panicum maximum $\left(1,0\right.$ e $\left.3,7 \mathrm{Mg} \mathrm{ha}^{-1}\right)$ na mesma localidade onde foi desenvolvido este trabalho, conforme relatou Andrade (1987), e compatíveis com as obtidas por Gomide \& Zago (2,1 e 4,2 $\mathrm{Mg} \mathrm{ha}^{-1}$ ), também para Panicum maximum, nos mesmos 


$$
\begin{array}{lllc}
\text { PFV } & Y=138-9.26 X+0,183 X^{2} & R^{2}=0,97 & n=15 \\
\text { PC } & Y=-118+29,9 X-1,89 X^{2}+0,04 X^{3} & R^{2}=0,99 & n=15 \\
\text { PS } & Y=-5,4+1,33 X & R^{2}=0,86 & n=12 \\
& & & P<0,05
\end{array}
$$

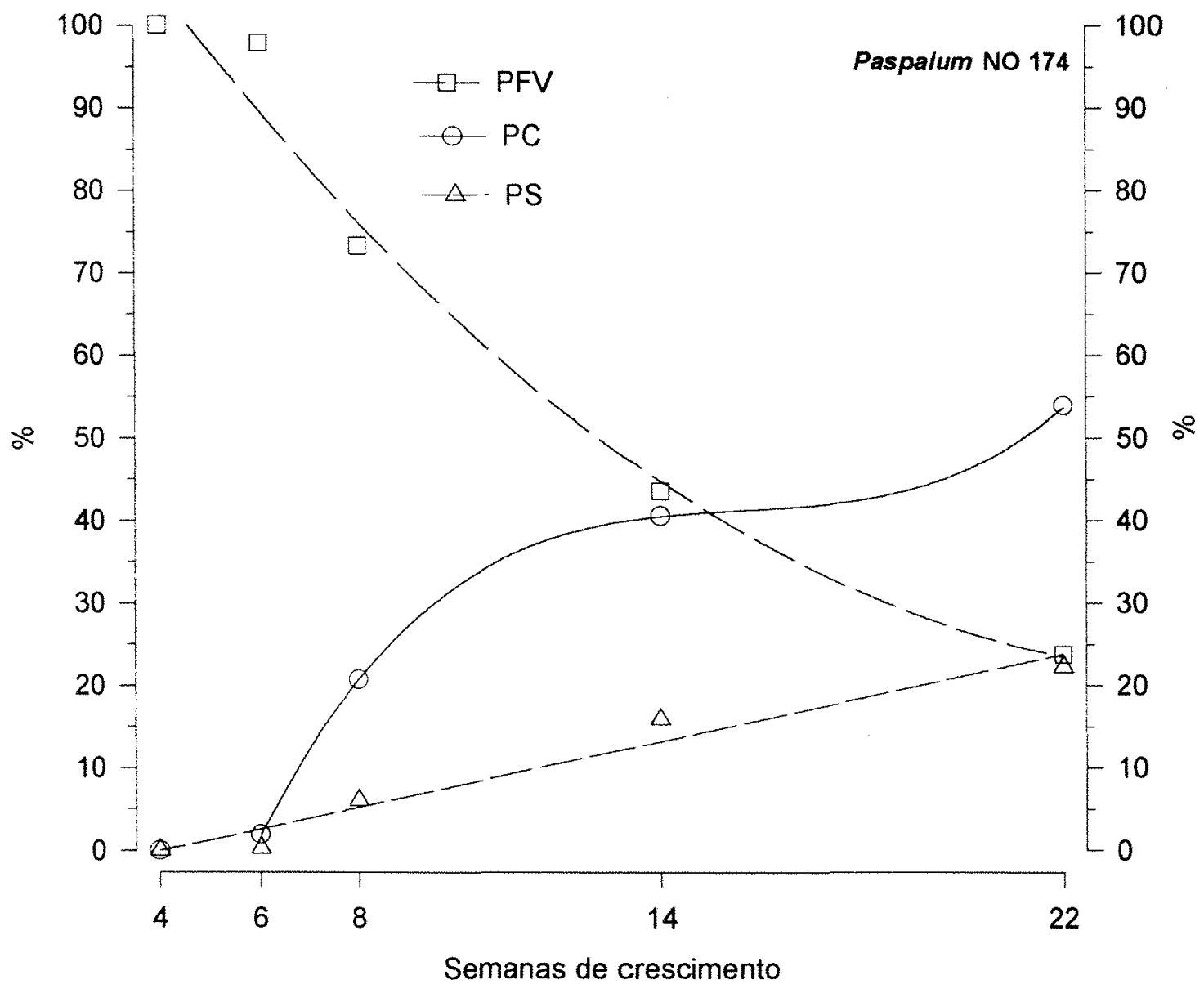

Figura 10. Porcentagem de folhas verdes (PFV), colmos (PC) e material senescido (PS) na forragem acumulada pelo Paspalum coryphaeum NO 174 em intervalos de crescimento no início da estação chuvosa. Nova Odessa, SP. 
intervalos de crescimento. As produções de forragem também foram superiores àquelas reportadas por Costa \& Oliveira (1992) e Costa \& Oliveira (1994) para Paspalum coryphaeum que obtiveram 2,0 e 4,2 Mg ha-1 após 6 e 12 semanas de crescimento, respectivamente. nas condições ecológicas de Rondônia, com menores aplicação de fertilizantes químicos. Também apresentou produção de forragem com 6 semanas de crescimento $\left(6,6 \mathrm{Mg} \mathrm{ha}^{-1}\right)$ acima das registradas pelos cinco genótipos mais produtivos, em 47 dias de crescimento, de uma coleção de Paspalum spp. avaliada por Pizarro \& Carvalho (1992). Neste trabalho o total produzido com 22 semanas $\left(17,4 \mathrm{Mg} \mathrm{ha}^{-1}\right)$ representou $80 \%$ do total anual produzido pelo Paspalum coryphaeum BRA000841 em São Carlos-SP, conforme relataram Batista et al. (1994). A produção de matéria seca de folhas registrada com 8 semanas $\left(4,9 \mathrm{Mg} \mathrm{ha}^{-1}\right)$ situou-se na faixa de produção para toda a estação chuvosa (2,8 a 5,2 Mg ha'1) de cultivares de Panicum maximum descrita por Jank (1994). Verifica-se que os rendimentos de forragem na estação chuvosa credenciam o Paspalum coryphaeum NO 174 para uso nesta época do ano.

A resposta linear na produção de forragem foi acompanhada pela da fração folhas verdes até 8 semanas de crescimento, considerando-se as médias registradas, passando a ser mais expressivo o processo de senescência (Figura 9). Todavia a partir de 6 semanas de crescimento o acúmulo de forragem foi condicionado principalmente pela fração colmos (Figura 10) cujo aproveitamento deve ocorrer de forma restrita. $O$ aproveitamento da forragem com até 6 semanas de crescimento seria o desejável, porém a disponibilidade de forragem é baixa considerando-se as quantidades de fertilizantes aplicadas. No intervalo de 8 semanas de crescimento a produção de forragem é o dobro da observada com 6 semanas, mas já apresenta quase $30 \%$ da forragem constituída por colmo e material senescido. Após 14 semanas de crescimento é elevada a oferta de forragem, porém $56 \%$ da mesma é composta por e colmos e material senescido, e a relação folha/colmo é próxima de 1. Deste modo, baseado em Euclides et al. (1989), como o desempenho animal em pastejo está 
associado com a disponibilidade de folhas verdes, e também pela estrutura da pastagem segundo Stobbs (1973b) e Forbes (1988), o aproveitamento da forragem nesta época representará baixa eficiência do ponto de vista da produção de forragem por conta das perdas por senescência, bem como pelo animal. $O$ aproveitamento da forragem após 8 semanas de crescimento implica perda progressiva, pois com 10 semanas os colmos e as folhas responderiam por $40 \%$ do total, em vez de $30 \%$ como ocorria com 8 semanas. Pelas estimativas do modelo $\circ$ incremento na disponibilidade de folhas seria de apenas $0,5 \mathrm{Mg} \mathrm{ha}^{-1}$ de folhas $(15 \%)$ em relação ao aproveitamento com 8 semanas.

\subsubsection{Perfilhos}

O número e o peso médio dos perfilhos basais do Paspalum coryphaeum NO 174 nos intervalos de crescimento são apresentados na figura 11. A análise de regressão não indicou efeito dos intervalos de crescimento sobre o número de perfilhos $(P=0,18)$. Em média o Paspalum coryphaeum apresentou $260 \pm 47$ perfilhos entre 4 e 22 semanas de crescimento. Por sua vez, o peso médio dos perfilhos basais variou de 0,65 (com 4 semanas) a 9,6 g (com 22 semanas), sendo a taxa média de incremento de $0,53 \mathrm{~g} \mathrm{semana}^{-1}$.

Considerando-se o espaçamento adotado no cultivo do mesmo verifica-se que a densidade de perfilhos é baixa, mesmo se comparada com a do cultivar IZ-1 neste experimento, o que implicaria menor competição e provavelmente menor mortalidade. A estabilidade na densidade de perfilhos parece indicar baixa mortalidade de perfilhos, mas também, limitada capacidade de perfilhamento deste genótipo (Figura 11). A estabilidade na densidade de perfilhos pode decorrer do sincronismo no perfilhamento por conta da adubação adotada, como sugeriu Langer (1963), uma vez que a existência de perfilhos 


$$
\begin{array}{lll}
\text { NP } & Y=260 \pm 47 & P=0,18 \\
\text { PMP } & Y=-1,61+0,53, X & R^{2}=0,99 \\
& & n=15 \quad P<0,05
\end{array}
$$

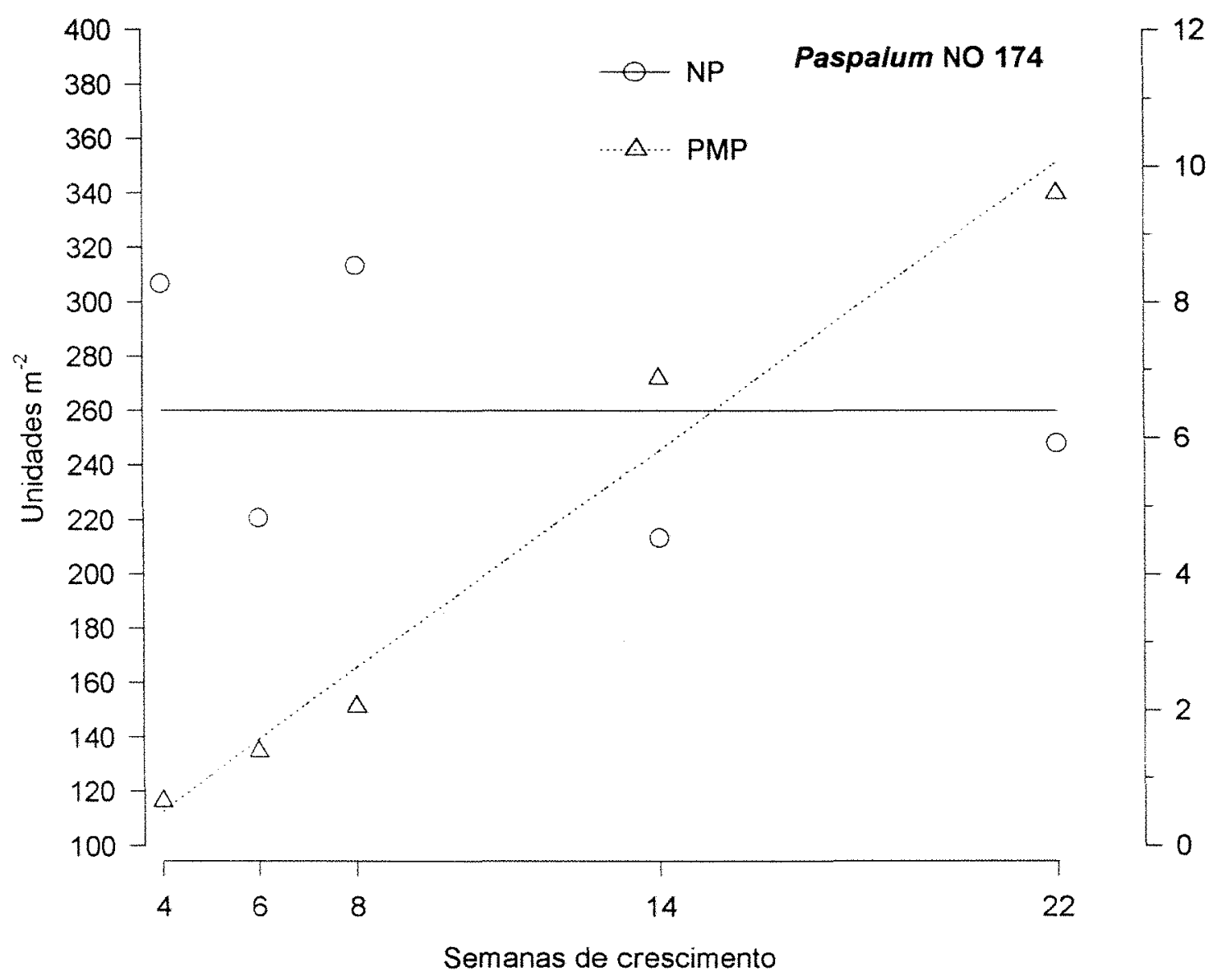

Figura 11. Densidade (NP) e peso médio de perfilhos basais (PMP) do Paspalum coryphaeum NO 174 em intervalos de crescimento no início da estação chuvosa. Nova Odessa, SP. 
com idades semelhantes, segundo Ludlow (1978) implicaria menor competição. De acordo com Andrade (1994), a existência de perfilhos com idades semelhantes é desejável em áreas de produção de sementes com colheita mecanizada

Para este genótipo $\circ$ comportamento produtivo foi definido predominantemente pelo tamanho do perfilho, não se observando a relação inversa entre o tamanho e a densidade dos perfilhos com o aumento nos intervalos de crescimento como pôde verificar Andrade (1987) em Panicum maximum cultivar IZ-1 e Tobiatã, bem como neste trabalho para o cultivar Aruana. Até 14 semanas de crescimento o peso médio dos perfilhos do Paspalum coryphaeum NO 174 equivaleu ao obtido neste trabalho para o cultivar IZ-1, e embora já estivesse na fase reprodutiva, com 22 semanas o seu peso médio foi inferior ao do cultivar IZ-1 (Tabelas 15 e 17).

4.1.3.3. Eliminação de meristemas apicais e vigor da rebrota

A figura 12 ilustra o comportamento produtivo da rebrota do Paspalum coryphaeum NO 174 após o corte nos intervalos de crescimento. Também são apresentadas a altura das plantas e a porcentagem de eliminação dos meristemas apicais dos perfilhos basais.

A altura das plantas variou de 25 (com 4 semanas) a $187 \mathrm{~cm}$ (com 22 semanas), elevando-se numa taxa média de $9 \mathrm{~cm}^{\text {semana }}{ }^{-1}$, contemplando predominantemente a fase vegetativa. Para a porcentagem de eliminação de meristemas apicais verificou-se o aumento mais expressivo entre $6(10 \%)$ e 8 semanas de crescimento (92\%). Com isso, a porcentagem de eliminação dos meristemas apicais deve ter atingido o seu máximo valor logo após 8 semanas. Pela equação polinomial, a estimativa da ocorrência do máximo seria com 14 semanas de crescimento. Outros modelos matemáticos também foram testados 


$\begin{array}{lll}\text { ALT } & Y=-7,17+9 X & R^{2}=0,93 \\ \text { PEMA } & Y=-162+48,95 X-2,94 X^{2}+0,057 X^{3} & R^{2}=0,86 \\ \text { VR28 } & Y=11191-2521 X+192,9 X^{2}-4,534 X^{3} & R^{2}=0,92 \\ & & n=15 \quad P<0,05\end{array}$

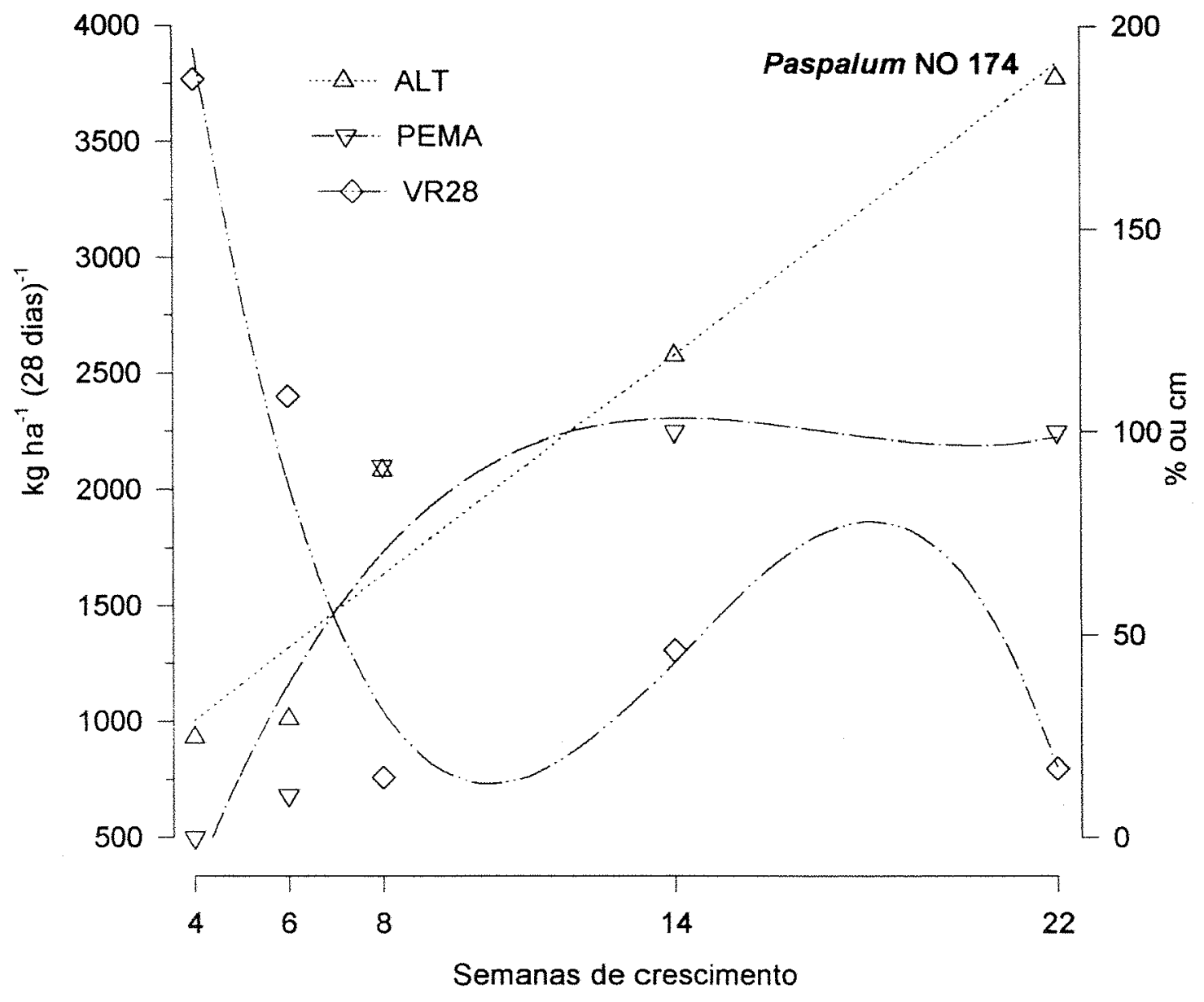

Figura 12. Altura da planta (ALT), porcentagem de eliminação de meristemas apicais de perfilhos basais após o corte (PEMA) e vigor da rebrota (VR28) do Paspalum coryphaeum NO 174 em intervalos de crescimento no início da estação chuvosa. Nova Odessa, SP. 
e apresentaram maior coeficiente de determinação, mas as estimativas tiveram comportamento errático para os intervalos entre 4 e 6 semanas ou entre 14 e 22 semanas de crescimento.

O vigor da rebrota decresceu drasticamente entre os cortes efetuados com $4\left(3,7 \mathrm{Mg} \mathrm{ha}^{-1}\right)$ e 8 semanas $\left(0,8 \mathrm{Mg} \mathrm{ha}^{-1}\right)$, voltando a apresentar média um pouco mais elevada com o corte após 14 semanas $\left(1,3 \mathrm{Mg} \mathrm{ha}^{-1}\right)$, para em seguida voltar a decrescer com o corte após 22 semanas $\left(0,8 \mathrm{Mg} \mathrm{ha}^{-1}\right.$ ) (Figura 12). A rebrota após os cortes efetuados nos intervalos de 8,14 e 22 semanas de crescimento foi, em média, de $0,96 \mathrm{Mg} \mathrm{ha}^{-1}$ em 28 dias. O polinômio selecionado estimou dois pontos de inflexão (10 e 18 semanas) no intervalo entre 8 e 22 semanas de crescimento, mostrando-se bastante sensível às pequenas variações das médias nestes intervalos. Para o conjunto de dados, o modelo definido por VR28 $=693+49293 /(\text { semanas })^{2}$, onde VR28 representa 0 vigor da rebrota, apresentou melhores estimativas das rebrotas para os cortes nos intervalos entre 8 e 22 semanas de crescimento, embora com menor coeficiente de determinação ajustado $\left(R^{2}=0,82\right)$. Todavia, como nos cortes efetuados entre 4 e 8 semanas, quando as médias para o vigor da rebrota experimentaram maior variação, as estimativas não ocorreram de forma errática, daí porque optou-se pelo modelo polinomial apresentado na figura 12, uma vez que o comportamento decrescente das médias foi bem caracterizado.

Redução no vigor da rebrota com $\circ$ aumento nos intervalos de crescimento também foi observada nos demais experimentos deste trabalho, bem como no trabalho de Gomide et al. (1979). O rendimento de forragem da rebrota (28 dias) superou em 2 vezes a produção apresentada no crescimento de 4 semanas (Tabela 14), uma vez que as condições climáticas eram progressivamente mais favoráveis e não houve eliminação de meristemas apicais. As rebrotas dos cortes efetuados com 4 ou 6 semanas (28 dias de crescimento) também apresentaram produções superiores às registradas por Costa \& Oliveira (1992) para esta mesma espécie após 42 dias de crescimento (2,0 Mg ha-1). A partir da tabela 15 pode-se verificar que novamente foi 
observada significância estatística para a correlação linear simples entre o vigor da rebrota e a porcentagem de eliminação dos meristemas apicais $(r=-0,89$; $P<0,01)$ e o vigor da rebrota e a altura da planta forrageira $(r=-0,78 ; P<0,01)$, assim como puderam observar Gomide \& Zago (1980) em Panicum maximum. Como não houve variação expressiva na densidade de perfilhos, nenhuma variável correlacionou-se significativamente com o mesmo (Tabela 15)

Uma vez que a redução no vigor da rebrota associa-se com a eliminação de meristemas apicais tem-se que o aproveitamento da forragem deve ocorrer mais precocemente visando maior rendimento de forragem pela rebrota. No entanto, busca-se conciliar a produção de forragem acumulada no crescimento primário (4 a 22 semanas) com a da rebrota subsequente. Deste modo, a eficiência produtiva ( $\mathrm{kg}$ de MS semana ${ }^{-1}$ ) considerando-se os dois períodos de crescimento ( 4 a 22 semanas mais a rebrota de 4 semanas) é alta inicialmente, no menor intervalo de crescimento, passando a decrescer para depois elevar-se em conseqüência do estímulo ao florescimento (Tabela 14, Figuras 9 e 12). Todavia a maior eficiência de acúmulo de matéria seca nos maiores intervalos de crescimento ocorre no crescimento primário com a participação crescente do material senescido e dos colmos, os quais oferecem restrições ao aproveitamento da forragem pelos animais. Então, a fração folhas verdes assume maior relevância na definição do intervalo de crescimento para a primeira desfolha da estação, sendo que nos intervalos de crescimento superiores a 8 semanas a forragem acumulada apresenta expressiva participação do material senescido e de colmos ( $>27 \%$ do total). Embora o vigor da rebrota não apresente grande amplitude entre 8 e 22 semanas de crescimento, a drástica redução que ele experimenta com o aproveitamento da forragem com 8 semanas de crescimento permite sugerir que 0 aproveitamento da foragem deve ocorrer antes de 8 semanas de crescimento quando não acompanhado de um maior periodo de descanso para o acúmulo de forragem na rebrota subsequente. 


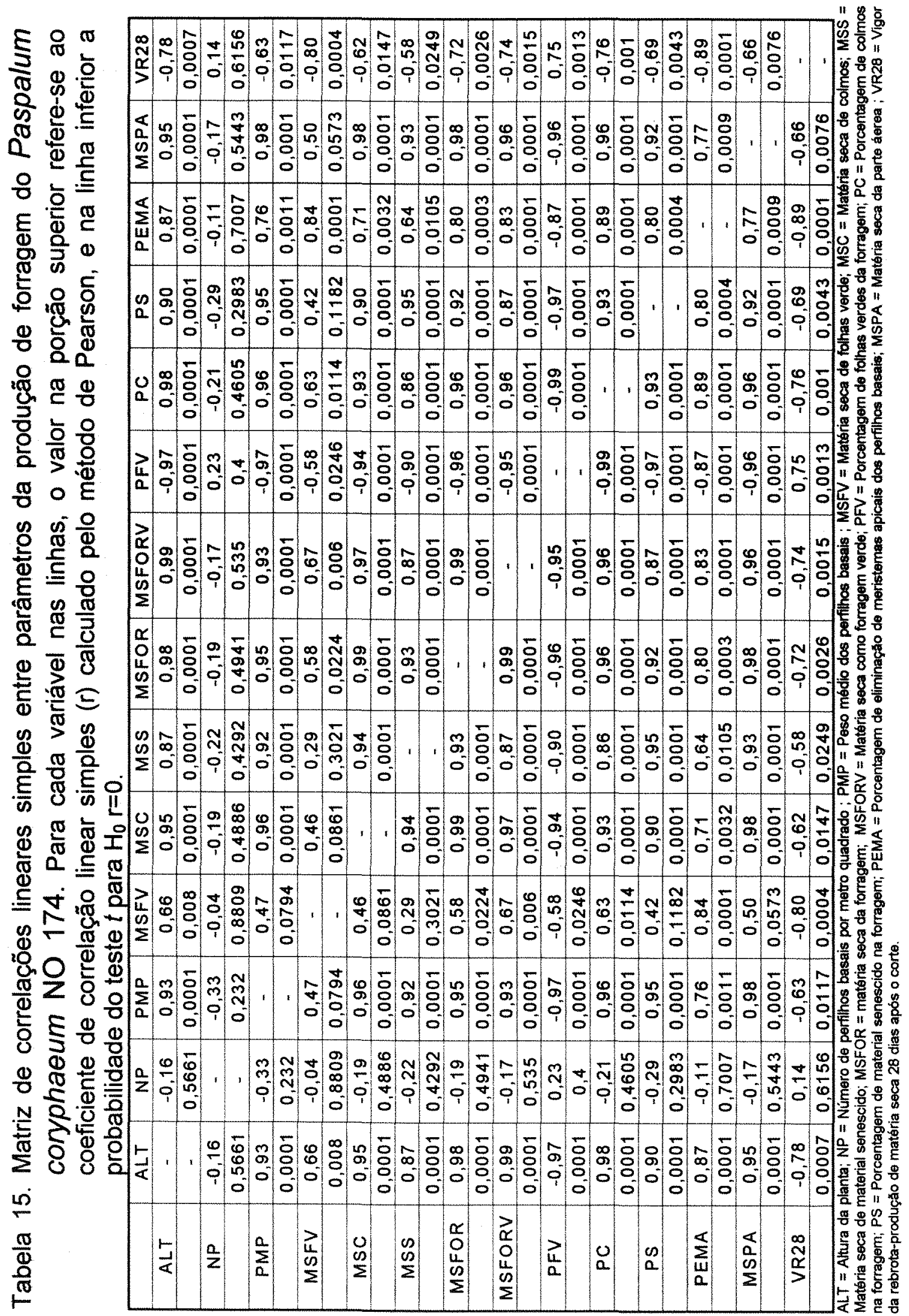




\subsection{Teores de nutrientes minerais}

\subsubsection{Panicum maximum cultivar Aruana}

$\mathrm{Na}$ Tabela 16 estão contidas as médias originais dos teores de macro e micronutrientes em frações da forragem nos intervalos de crescimento do cultivar Aruana.

\subsubsection{Macronutrientes}

O comportamento dos teores dos macronutrientes minerais na forragem do cultivar Aruana nos intervalos de crescimento é ilustrado na figura 13. O teor de nitrogênio na forragem verde, nas folhas verdes e nos colmos apresentou resposta quadrática ao aumento no intervalo de crescimento. Nas folhas verdes os teores de nitrogênio foram superiores ao teores dos colmos, com as diferenças dentro de cada intervalo de crescimento tendendo a diminuir após 8 semanas de crescimento.

Os teores de nitrogênio variaram de 3,9 a $1,2 \mathrm{~g}(100 \mathrm{~g})^{-1}$, e de 1,4 a 0,4 $\mathrm{g}(100 \mathrm{~g})^{-1}$, para as folhas verdes e colmos, respectivamente, à medida que se elevou o intervalo de crescimento. $\mathrm{Na}$ forragem verde, os teores foram intermediários aos das frações que o compunham, estando as maiores médias nos menores intervalos de crescimento, quando a participação das folhas verdes na forragem era maior. A amplitude registrada foi de 3,9 a $0,6 \mathrm{~g}(100 \mathrm{~g})^{-1}$.

Os teores de nitrogênio nas folhas só foram superiores aos relatados por Vieira et al. (1980), até 4 semanas, sendo que nos colmos em todas as épocas os valores foram inferiores. Todavia, os teores na parte aérea e folhas estiveram acima dos relatados por Ghisi et al. (1989) para este mesmo cultivar até 8 


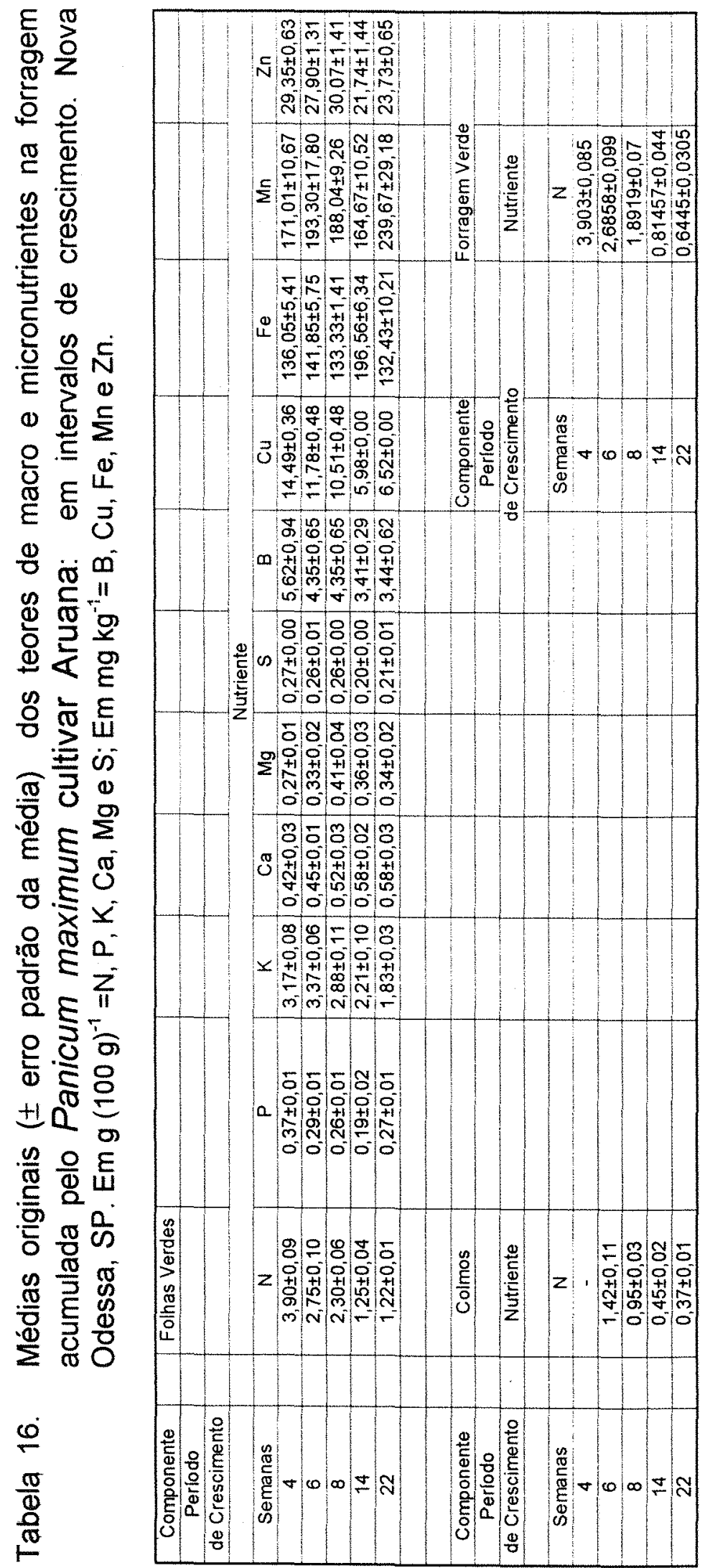




$\begin{array}{lll}N \text {-forv } & Y=5,9-0,62 X+0,018 X^{2} & R^{2}=0,98 \\ N & Y=5,6-0,53 X+0,015 X^{2} & R^{2}=0,97 \\ N-c & Y=2,7-0,26 X+0,007 X^{2} & R^{2}=0,94 \\ P & Y=0,51-0,045 X+0,0015 X^{2} & R^{2}=0,90 \\ K & Y=3,6-0,086 X & R^{2}=0,89 \\ \text { Ca } & Y=0,3+0,033 X-0,0009 X^{2} & R^{2}=0,72 \\ M g & Y=0,19+0,03 X-0,0011 X^{2} & R^{2}=0,38 \\ S & Y=0,33-0,013 X+0,0004 X^{2} & R^{2}=0,83 \\ & & n=15 \quad P<0,05\end{array}$

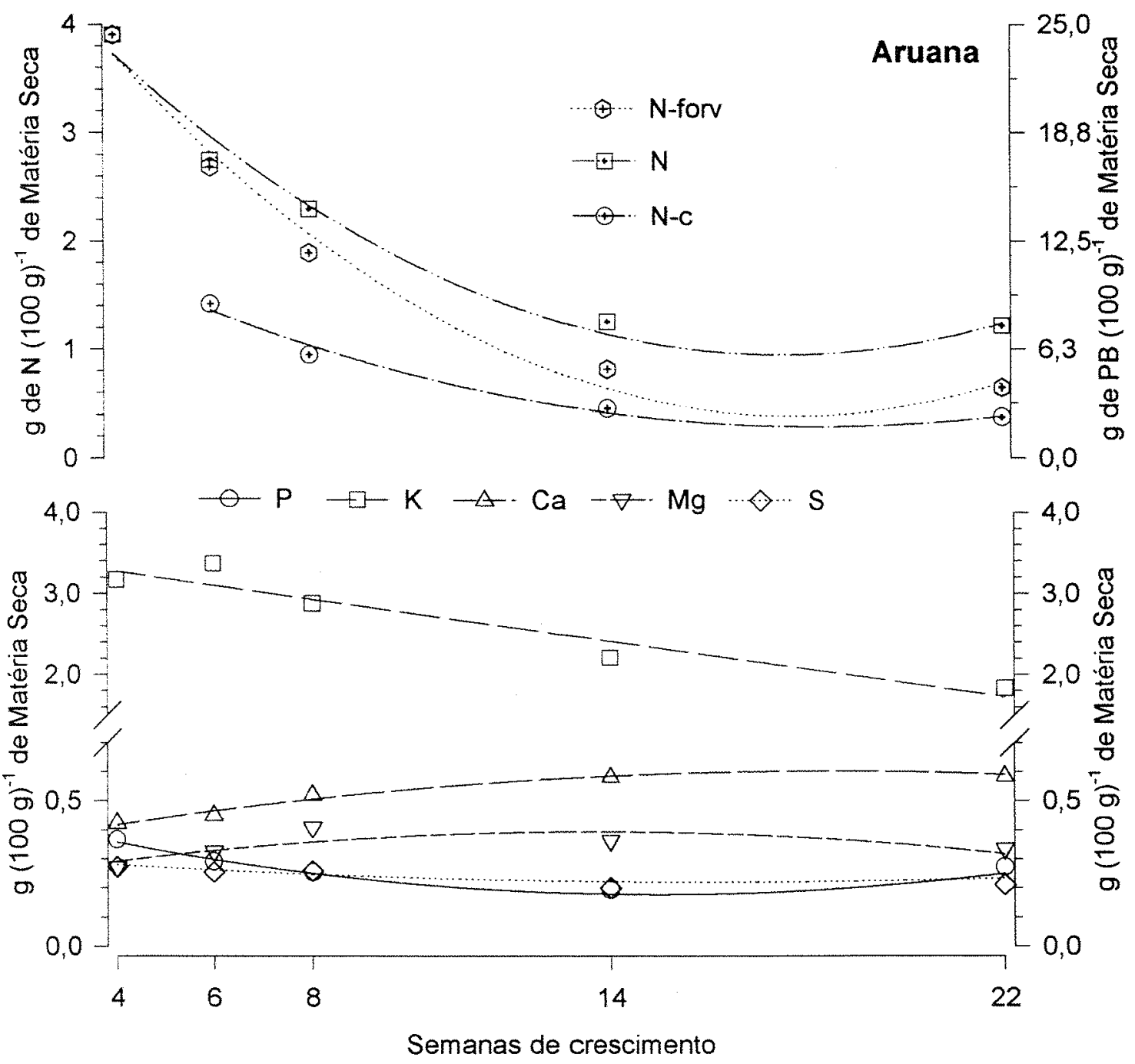

Figura 13. Teores de macronutrientes nas folhas, colmos (-c) e na forragem (-forv) do Panicum maximum cultivar Aruana em períodos de crescimento no início da estação chuvosa. Nova Odessa, SP. $\mathrm{PB}=$ Proteína Bruta. 
semanas de crescimento. Também até 8 semanas, o teor de nitrogênio na forragem era suficiente para atender os requerimentos nutricionais mínimos em bovinos leiteiros (NRC, 1988).

O teor de fósforo apresentou resposta quadrática aos intervalos de crescimento, sendo que as médias foram decrescentes até 15 semanas $(0,18 \mathrm{~g}$ $\left(100 \mathrm{~g}^{-1}\right)$, após o que elevaram-se. Os teores registrados com 4 , 6 , e 8 semanas foram de 0,$37 ; 0,29,0,26 \mathrm{~g}(100 \mathrm{~g})^{-1}$ respectivamente. Considerandose apenas as folhas, os teores de fósforo, também atenderiam as exigências nutricionais mínimas de bovinos leiteiros (NRC,1988) e estiveram acima ou dentro da faixa de nível crítico interno $\left(0,17-0,29 \mathrm{~g}(100 \mathrm{~g})^{-1}\right)$ relatada por Meirelles et al. (1988) para a espécie.

Para o potássio, o teor diminuiu de forma linear com a elevação do intervalo de crescimento, em taxas médias de $0,086 \mathrm{~g}(100 \mathrm{~g})^{-1}$ por semana. A amplitude registrada foi de 3,2 (com 4 semanas) a $1,8 \mathrm{~g}(100 \mathrm{~g})^{-1}$ (com 22 semanas). Estes teores estão bem acima das exigências nutricionais de bovinos de corte e leite (NRC,1984; 1988), e acima dos relatados por Andrade (1987).

Os teores de cálcio tiveram resposta quadrática ao aumento do intervalo de crescimento, e variaram de 0,42 (4 semanas) a 0,58 (14 e 22 semanas), com a estimativa do teor máximo ocorrendo com 18 semanas.

As concentrações de magnésio variaram de forma quadrática com os intervalos de crescimento, sendo que a máxima concentração $(0,39)$, estimada, ocorreu com 14 semanas. Os teores registrados nos demais intervalos foram 0,$29 ; 0,33 ; 0,36$ e $0,32 \mathrm{~g}(100 \mathrm{~g})^{-1} \operatorname{com~} 4,6,8$, e 22 semanas.

Por sua vez, os teores de enxofre decresceram até 14 semanas $(0,20 \mathrm{~g}$ $\left(100 \mathrm{~g}^{-1}\right)$, com tendência à estabilização após este período. Entre 4 e 8 semanas os teores situaram-se entre 0,26 e $0,27 \mathrm{~g}(100 \mathrm{~g})^{-1}$.

Os teores de cálcio, magnésio e enxofre estiveram em todas as épocas de avaliação acima das exigências nutricionais mínimas na dieta de gado de leite (NRC, 1988). Para o cálcio, os teores superaram os relatados por Vieira et 
al. (1980), enquanto que para o magnésio, foram inferiores aos relatados por Gomide et al. (1969) e para o enxofre, bem superiores aos apresentados por Andrade (1987) e França \& Haag (1985).

\subsubsection{Micronutrientes}

O comportamento dos teores dos micronutrientes minerais nas folhas verdes do cultivar Aruana com o crescimento é ilustrado na figura 14.

Os teores de boro, manganês e zinco apresentaram respostas lineares aos intervalos de crescimento, sendo que os teores de boro e de zinco decresceram com o incremento do intervalo de crescimento, em taxas médias de 0,10 e $0,39 \mathrm{mg} \mathrm{kg}^{-1}$ semana $^{-1}$. Os teores de boro e zinco variaram de 5,6 a 3,4 e de 29,3 a $23,7 \mathrm{mg} \mathrm{kg}^{-1}$, respectivamente. Os teores de $\mathrm{Mn}$ elevaram-se com os intervalos de crescimento, sendo estimado o incremento médio de 2,79 $\mathrm{mg} \mathrm{kg}{ }^{-1}$ em cada semana de crescimento. Com $4 ; 6$ e 8 semanas foram registrados teores de 171,193 e $188 \mathrm{mg} \mathrm{kg}^{-1}$ de $\mathrm{Mn}$ nas folhas verdes do cultivar Aruana.

Para os teores de cobre e ferro as respostas foram quadráticas, porém com padrões distintos. Os teores de cobre decresceram de 14,5 (com 4 semanas) para $6,0 \mathrm{mg} \mathrm{kg}^{-1}$ (com 14 semanas), após o que apresentaram pequena variação. Por sua vez, os teores de $\mathrm{Fe}$ foram crescentes até 16 semanas, diminuindo em seguida. Entre 4 e 8 semanas, os teores de $\mathrm{Fe}$ não apresentaram maiores variações e situaram-se entre 133 e $141 \mathrm{mg} \mathrm{kg}^{-1}$, para em seguida elevarem-se para $196 \mathrm{mg} \mathrm{kg}^{-1}$ com 14 semanas de crescimento.

Os teores de boro situaram-se bem abaixo dos relatados por Gallo et al. (1974), em todas as épocas, enquanto que os teores de zinco apresentaram-se abaixo das exigências nutricionais em bovinos de leite. Por sua vez, os teores de ferro registrados foram inferiores aos obtidos por Gomide et al. (1969), para a parte aérea, mas ainda acima do preconizado para as dietas de gado de corte por NRC (1984). 


$\begin{array}{lll}\mathrm{B} & \mathrm{Y}=5,4-0,102 \mathrm{X} & \mathrm{R}^{2}=0,29 \\ \mathrm{Cu} & \mathrm{Y}=20,5-1,7 X+0,048 X^{2} & \mathrm{R}^{2}=0,97 \\ \mathrm{Fe} & \mathrm{Y}=67+16,1 \mathrm{X}-0,59 \mathrm{X}^{2} & \mathrm{R}^{2}=0,52 \\ \mathrm{Mn} & \mathrm{Y}=161+2,79 X & \mathrm{R}^{2}=0,26 \\ \mathrm{Zn} & \mathrm{Y}=30,7-0,39 X & \mathrm{R}^{2}=0,48 \\ & & \mathrm{n}=15 \mathrm{P}<0,05\end{array}$

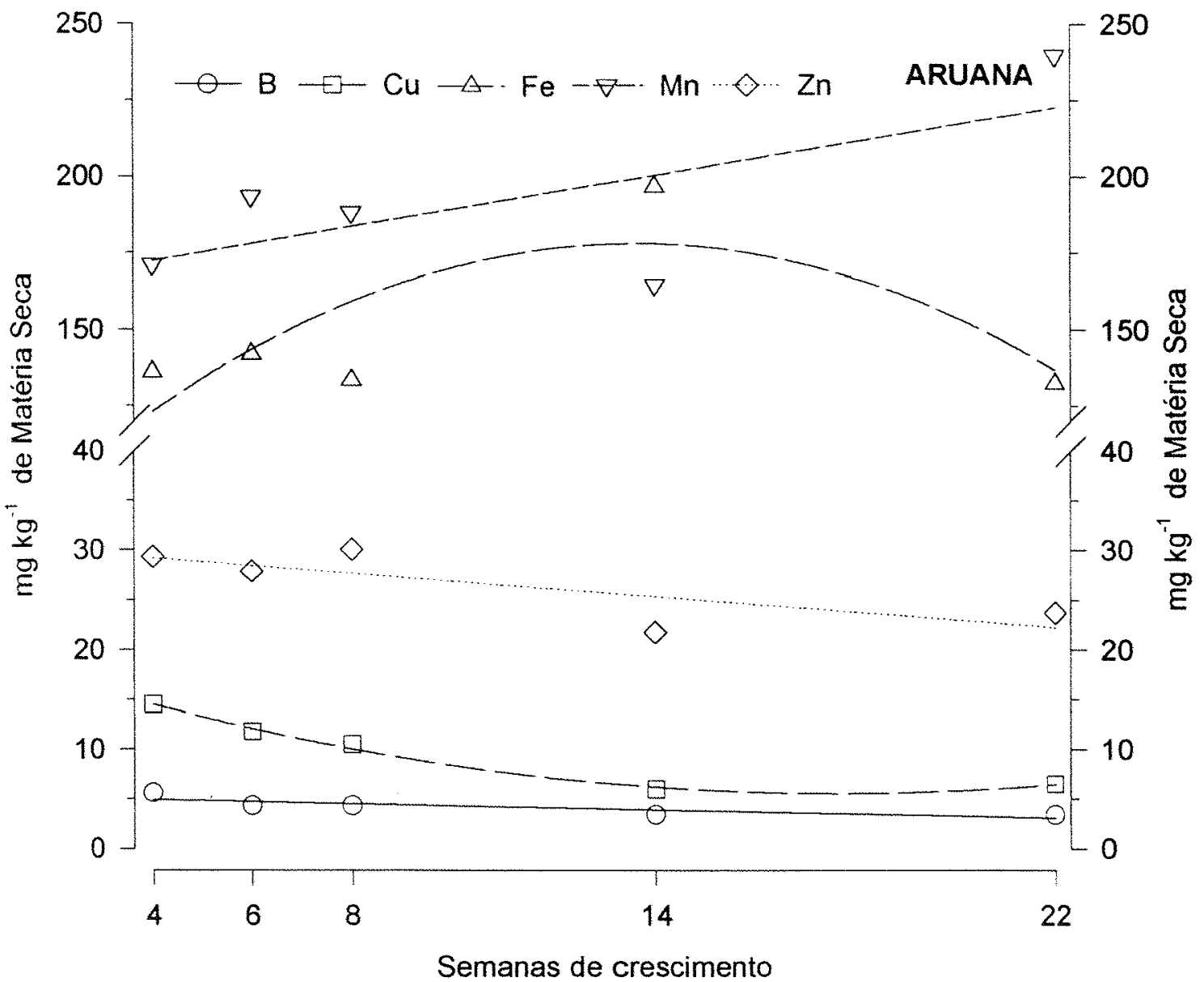

Figura 14. Teores de micronutrientes nas folhas, colmos $(-c)$ e na forragem (-forv) do Panicum maximum cultivar Aruana em períodos de crescimento no início da estação chuvosa. Nova Odessa, SP. 


\subsubsection{Panicum maximum cultivar $\mathrm{IZ}-1$}

$\mathrm{Na}$ Tabela 17 estão contidas as médias originais dos teores de macro e micronutrientes em frações da forragem nos intervalos de crescimento do cultivar IZ-1.

\subsubsection{Macronutrientes}

O comportamento dos teores dos macronutrientes minerais na forragem do cultivar IZ-1 nos intervalos de crescimento é ilustrado na figura 15. Os teores de nitrogênio nas folhas verdes decresceram de forma quadrática à medida que elevou-se o intervalo de crescimento, com a menor média estimada ocorrendo por volta de 17 semanas $\left(0,23 \mathrm{~g}\left(100 \mathrm{~g}^{-1}\right)\right.$. As maiores concentrações, mas também os maiores decréscimos, ocorreram entre $4\left(3,8 \mathrm{~g}(100 \mathrm{~g})^{-1}\right)$ e 8 semanas $\left(1,4 \mathrm{~g}(100 \mathrm{~g})^{-1}\right)$. Entre estes intervalos o decréscimo foi em média de $0,6 \mathrm{~g}\left(100 \mathrm{~g}^{-1}\right.$ semana $^{-1}$. Por conta disso, somente até 6 semanas de crescimento o cultivar IZ-1 poderia atender as exigências nutricionais mínimas em gado de leite (1988), porém dependendo da categoria animal em gado de corte poderão ser atendidas as exigências mínimas (NRC, 1984).

Nos colmos os teores de nitrogênio foram menores que os registrados para as folhas verdes e decresceram em média $0,054 \mathrm{~g}\left(100 \mathrm{~g}^{-1}\right.$ semana $^{-1}$ no período entre 8 e 22 semanas. Estes teores de nitrogênio nas folhas foram superiores aos reportados por Vieira et al. (1980), porém nos colmos foram menores.

$\mathrm{Na}$ forragem verde disponivel (colmos+folhas) os teores de nitrogênio apresentaram resposta quadrática aos intervalos de crescimento em decorrência da participação tardia dos colmos na forragem, quando também eram menores as diferenças nas concentração entre as folhas verdes e os 


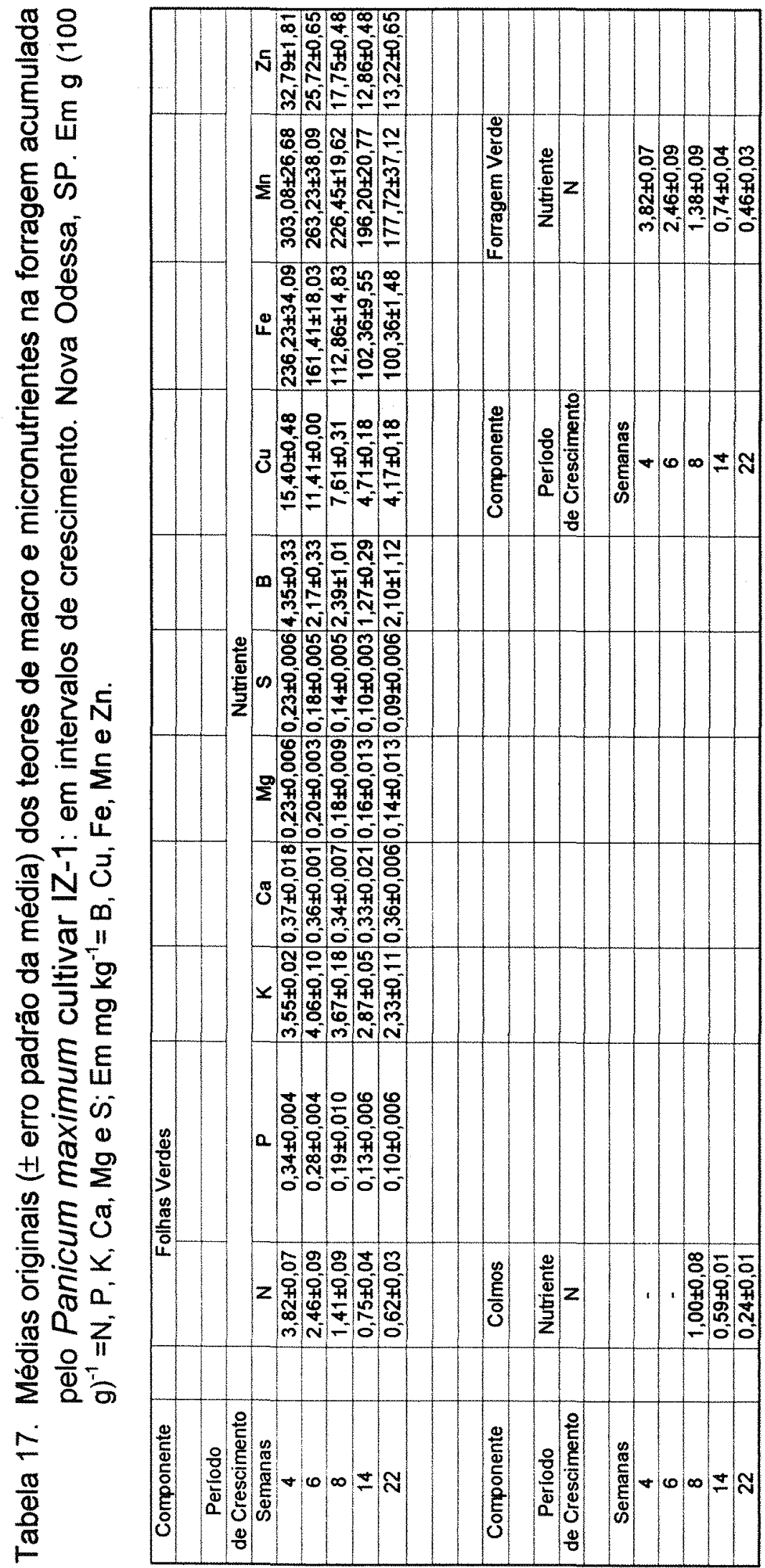




$\begin{array}{llll}N \text {-forv } & Y=5,8-0,65 X+0,019 X^{2} & R^{2}=0,94 & \\ N & Y=5,9-0,66 X+0,019 X^{2} & R^{2}=0,94 & \\ N-c & Y=1,4-0,054 X & R^{2}=0,94 \quad n=9 \\ P & Y=0,49-0,044 X+0,0012 X^{2} & R^{2}=0,94 & \\ K & Y=4,2-0,0875 X & R^{2}=0,81 & \\ \text { Ca } & Y=0,35 \pm 0,001 & P=0,56 & \\ M g & Y=0,27-0,0131 X+0,00033 X^{2} & R^{2}=0,81 & \\ S & Y=0,31-0,026 X+0,000074 X^{2} & R^{2}=0,91 \quad & \\ & & n=15 \quad P<0,05\end{array}$
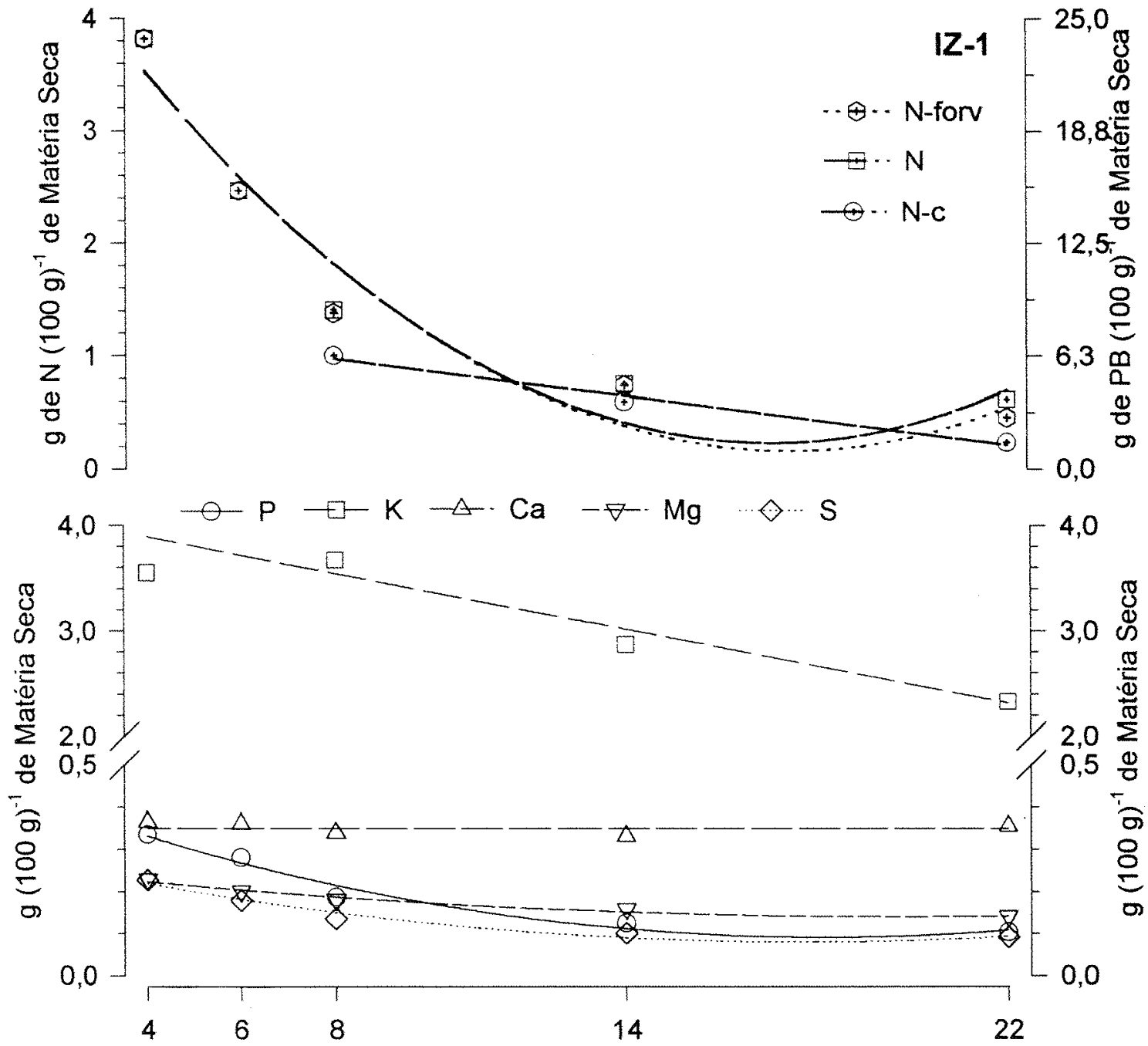

Semanas de crescimento

Figura 15. Teores de macronutrientes nas folhas, colmos $(-c)$ e na forragem (-forv) do Panicum maximum cultivar $\mathrm{IZ}-1$ em períodos de crescimento no início da estação chuvosa. Nova Odessa, SP. PB=Proteína Bruta. 
colmos, e praticamente na mesma magnitude que nas folhas verdes, sendo os coeficientes dos polinômios praticamente iguais.

Para as folhas verdes, as concentrações de fósforo, magnésio e enxofre variaram de forma quadrática com o aumento no periodo de crescimento. Novamente os maiores decréscimos relativos ocorreram entre 4 e 8 semanas, com maior taxa para o fósforo. Os teores de fósforo variaram de 0,34 (com 4 semanas) a 0,10 (com 22 semanas), enquanto que no mesmos intervalos os teores de magnésio foram de 0,23 e $0,14 \mathrm{~g}(100 \mathrm{~g})^{-1}$. Por sua vez, os teores de enxofre situaram-se entre 0,23 e $0,09 \mathrm{~g}(100 \mathrm{~g})^{-1}$. Até 8 semanas de crescimento os teores de fósforo supririam as exigências nutricionais mínimas da dieta de bovinos leiteiros. Também após 8 semanas os teores estiveram abaixo do nível crítico interno para plantas de Panicum maximum cultivar. $I Z-1$, segundo Meirelles et al. (1988).

Os teores de potássio decresceram de forma linear com o aumento do intervalo de crescimento, sendo os decréscimos da ordem de $0,09 \mathrm{~g}(100 \mathrm{~g})^{-1}$ para cada semana. Entre 4 e 6 semanas os teores de potássio registrados foram de 3,5 e $4,0 \mathrm{~g}\left(100 \mathrm{~g}^{-1}\right.$, respectivamente, e mantiveram-se acima de $2,5 \mathrm{~g}$ $\left(100 \mathrm{~g}^{-1}\right.$ com 14 semanas.

O teor de cálcio nas folhas verdes foi em média $0,35 \mathrm{~g}(100 \mathrm{~g})^{-1}$, não diferindo ao longo do período de crescimento. Desta forma, a relação cálcio:fósforo nas folhas verdes tornou-se maior com o intervalo de crescimento pelo decréscimo no teor de fósforo.

Os teores de potássio nas folhas superaram aqueles exigidos na dieta de bovinos, enquanto que os teores de cálcio e magnésio, supririam as exigências mínimas da dieta para a manutenção do peso em bovinos de leite ou corte. Todavia os teores de enxofre após 8 semanas de crescimento atenderiam apenas os requerimentos nutricionais de bovinos de corte (NRC, 1984, 1988). 


\subsubsection{Micronutrientes}

As variações com o crescimento nos teores dos micronutrientes minerais analisados nas folhas verdes do cultivar IZ-1 são ilustradas na figura 16 .

Os micronutrientes analisados apresentaram resposta quadrática aos intervalos de crescimento, exceto para o manganês. Os maiores decréscimos ocorreram entre 4 e 8 semanas de crescimento.

Os menores teores estimados de boro, cobre, ferro e zinco ocorreram após 15 semanas, equivalendo a 1,1; 3,1; 75 e $10 \mathrm{mg} \mathrm{kg}^{-1}$ nos tecidos foliares, respectivamente. Para este nutrientes, os teores com 4 e 22 semanas foram de 4,3 e 2,1; 15,4 e 4,2; 236 e 100; e 33 e $13 \mathrm{mg} \mathrm{kg}^{-1}$, respectivamente. Para o mesmo período, os teores de manganês diminuíram de 303 para $178 \mathrm{mg} \mathrm{kg}^{-1}$, numa taxa média de $6,3 \mathrm{mg} \mathrm{kg}^{-1}$ semana ${ }^{-1}$.

Em todos os intervalos de crescimento os teores de Fe e Mn situaram-se acima das exigências nutricionais de bovinos, bem como acima dos teores relatados para o cultivar Tobiatã por França \& Haag (1986), enquanto que os teores de B situaram-se bem abaixo dos reportados por Gallo et al. (1974).

Para o cobre, os teores nos intervalos de crescimento situaram-se abaixo dos relatados por Gomide et al. (1969), porém semelhantes aos relatados por Andrade (1987) nos maiores intervalos de crescimento. 


$$
\begin{array}{lll}
B & Y=6,3-0,69 X+0,022 X^{2} & R^{2}=0,41 \\
\text { Cu } & Y=22,7-2,25 X+0,064 X^{2} & R^{2}=0,96 \\
\text { Fe } & Y=322-30,5 X+0,94 X^{2} & R^{2}=0,68 \\
M n & Y=301-6,29 X & R^{2}=0,44 \\
Z n & Y=47,3-4,43 X+0,13 X^{2} & R^{2}=0,93 \\
& & n=15 P<0,05
\end{array}
$$

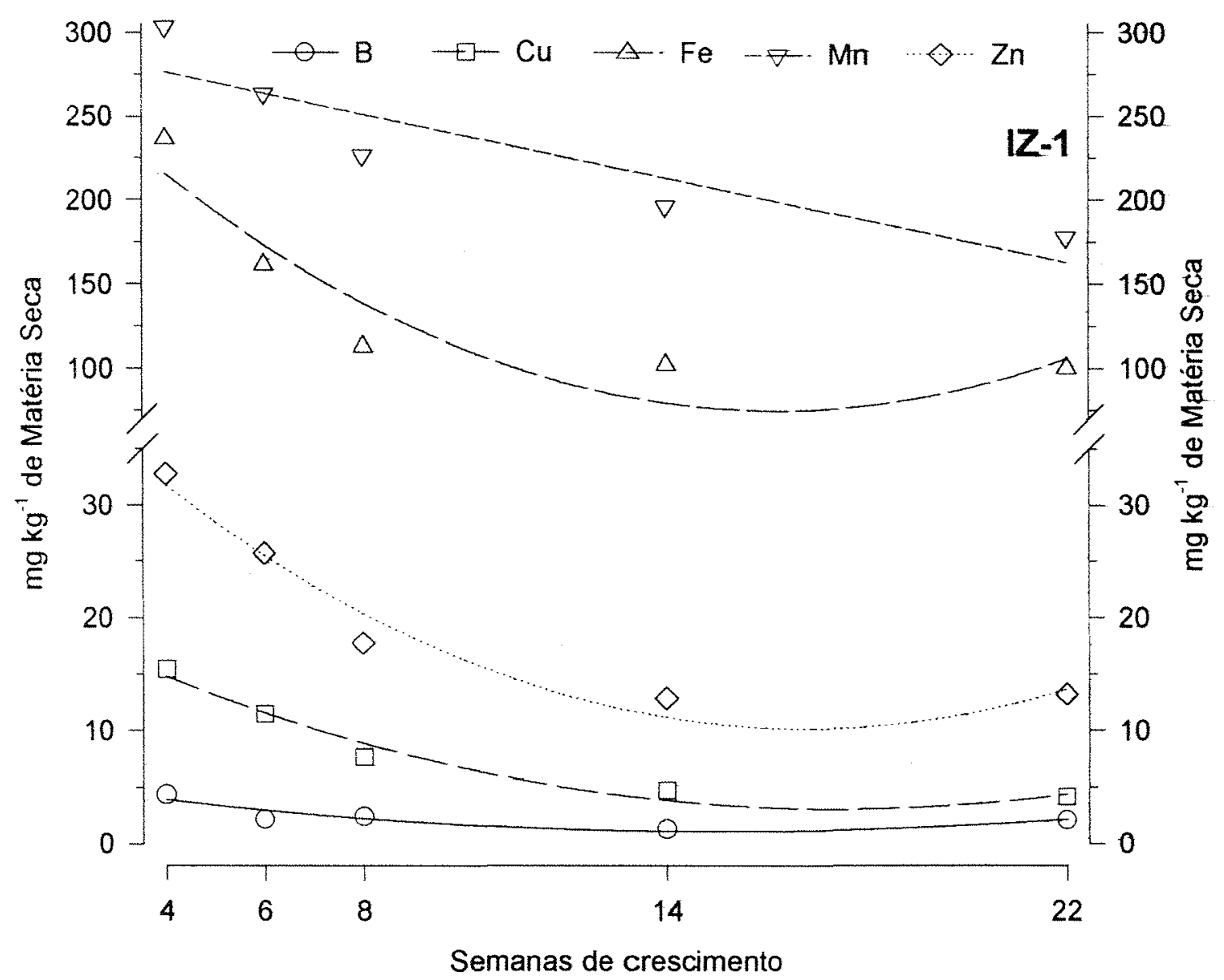

Figura 16. Teores de micronutrientes nas folhas, colmos $(-c)$ e na forragem (-forv) do Panicum maximum cultivar $\mathbf{Z}-1$ em períodos de crescimento no início da estação chuvosa. Nova Odessa, SP. 


\subsubsection{Paspalum coryphaeum NO 174}

$\mathrm{Na}$ Tabela 18 estão contidas as médias originais dos teores de macro e micronutrientes em frações da forragem nos intervalos de crescimento do Paspalum coryphaeum NO 174.

\subsubsection{Macronutrientes}

Na figura 17 é ilustrada a variação nos teores dos macronutrientes em frações da forragem produzida pelo Paspalum coryphaeum NO 174 nos intervalos de crescimento.

Os teores de nitrogênio nas folhas verdes e colmos apresentaram resposta quadrática aos intervalos de crescimento. Com 8 semanas, quando os colmos passaram a compor a forragem em maior proporção, as diferenças nos teores de nitrogênio entre folhas e colmos ampliaram-se. Foi estimada em 19 semanas a ocorrência das menores concentrações de nitrogênio nas folhas verdes e colmos. Com 4 semanas de crescimento o teor de nitrogênio nas folhas verdes era de $2,8 \mathrm{~g}(100 \mathrm{~g})^{-1}$ passando a decrescer, sendo que para o período entre 4 e 8 semanas, os teores de nitrogênio diminuiram em média 0,28 $\mathrm{g}(100 \mathrm{~g})^{-1}$ por semana, enquanto que para os colmos entre 6 e 8 semanas o decréscimo foi de $0,59 \mathrm{~g}(100 \mathrm{~g})^{-1}$ por semana. Com isso os teores registrados com 8 semanas de crescimento nos colmos e folhas foram de 0,95 e $1,67 \mathrm{~g}$ (100 $\mathrm{g})^{-1}$, respectivamente. Logicamente, a resposta para a forragem verde foi intermediária àquela registrada para os colmos e as folhas verdes.

Para a forragem verde os teores foram superiores aos reportados por Costa et al. (1992) para mesma espécie e apenas com menos de 6 semanas os teores foram superiores aos teores relatados por Pizarro \& Carvalho (1992) para 


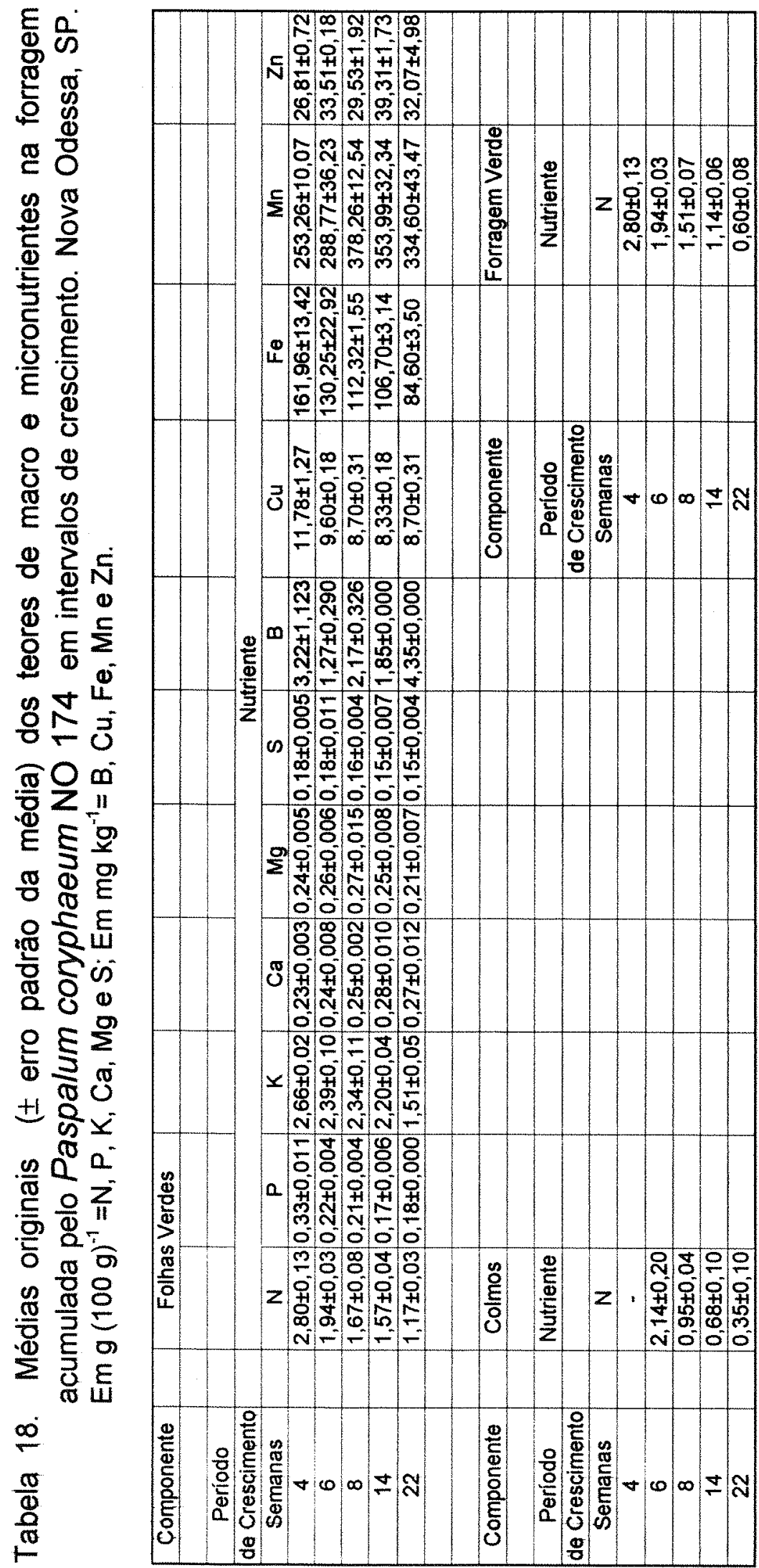




$\begin{array}{lllll}N \text {-forv } & Y=3,6-0,3 X+0,007 X^{2} & R^{2}=0,91 & \\ N & Y=3,4-0,23 X+0,006 X^{2} & R^{2}=0,80 & & \\ N \text {-c } & Y=3,7-0,37 X+0,01 X^{2} & R^{2}=0,77 & n=12 & \\ P & Y=0,42-0,035 X+0,001 X^{2} & R^{2}=0,83 & & \\ \text { K } & Y=2,8-0,057 X & R^{2}=0,88 & & \\ \text { Ca } & Y=0,18+0,012 X-0,0004 X^{2} & R^{2}=0,76 & & \\ \text { Mg } & Y=0,22+0,007 X-0,0004 X^{2} & R^{2}=0,61 & & \\ S & Y=0,183-0,002 X & R^{2}=0,47 & n=15 \quad P<0,05\end{array}$
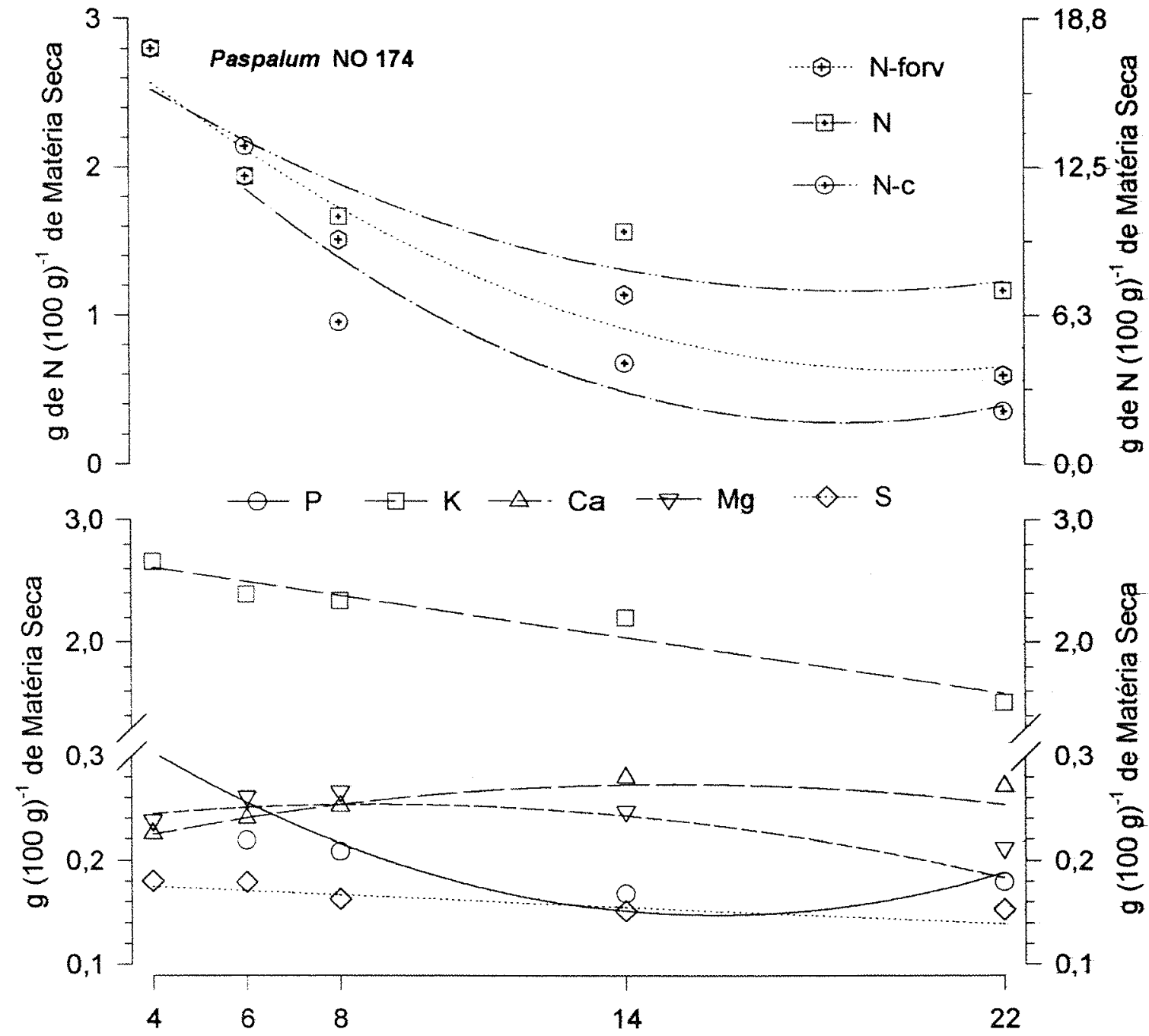

Semanas de crescimento

Figura 17. Teores de macronutrientes nas folhas, colmos (-c) e na forragem (-forv) do Paspalum coryphaeum NO 174 em períodos de crescimento no início da estação chuvosa. Nova Odessa, SP. PB=Proteína Bruta. 
a parte aérea de espécies do gênero Paspalum. Supondo apenas as folhas compondo a dieta, tem-se que por volta de 8 semanas ainda seriam atendidas as exigências nutricionais de algumas categorias de bovinos leiteiros (NRC, 1988).

As concentrações de fósforo, cálcio e magnésio nas folhas verdes também tiveram resposta quadrática aos intervalos de crescimento, porém com padrão distinto para o fósforo, cuja concentração diminuiu nos menores intervalos de crescimento, ao passo que para o cálcio e para o magnésio as médias elevaram-se. A amplitude da média entre 4 e 22 semanas de crescimento foi pequena para ambos, ao contrário da observada para o fósforo.

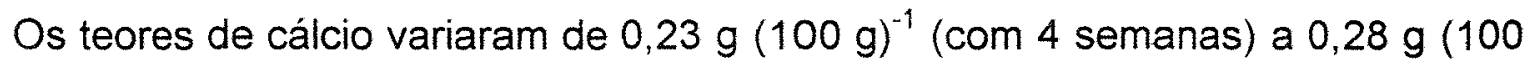
$\mathrm{g})^{-1}$ ( com 14 semanas), enquanto que para o magnésio, a variação foi de $0,21 \mathrm{~g}$ $\left(100 \mathrm{~g}^{-1}\right.$ (com 22 semanas) a $0,27 \mathrm{~g}(100 \mathrm{~g})^{-1}$ (com 8 semanas). Todavia para 0 fósforo variou de $0,17 \mathrm{~g}(100 \mathrm{~g})^{-1}$ (com 14 semanas) a $0,33 \mathrm{~g}(100 \mathrm{~g})^{-1}$ (com 4 semanas).

Os teores de fósforo foram superiores aos relatados por Gallo et al. (1974) e Cook \& Mulder (1984b) apenas até 4 semanas de crescimento. Todavia até 8 semanas de crescimento seriam suficientes para atender as exigências nutricionais de bovinos em pastejo, porém os teores de cálcio foram inferiores aos reportados por Gallo et al. (1974), e em todas as épocas também foram inferiores às exigências nutricionais de bovinos (NRC, 1984; 1988). Os teores de magnésio apresentaram média semelhante a relatada por Gallo et al. (1974) para Paspalum notatum.

Para o potássio e para $\circ$ enxofre os teores nas folhas verdes decresceram linearmente com o aumento do intervalo de crescimento em taxas médias de $0,057 \mathrm{~g}(100 \mathrm{~g})^{-1}$ e $0,002 \mathrm{~g}(100 \mathrm{~g})^{-1}$ semana $^{-1}$, respectivamente. $\mathrm{O}$

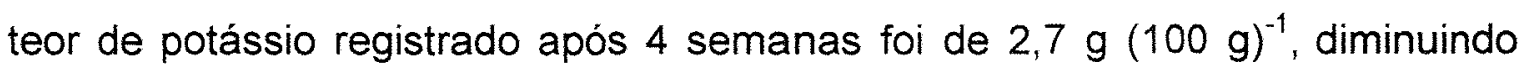
para $2,2 \mathrm{~g}(100 \mathrm{~g})^{-1}$ após 14 semanas. Para o enxofre, cujo taxa de decréscimo foi pequena, os teores registrados após 4 e 22 semanas foram de 0,18 e $0,15 \mathrm{~g}$ $\left(100 \mathrm{~g}^{-1}\right.$, respectivamente. Os teores de potássio foram superiores aos 
relatados por Gallo et al. (1974) até a idade de 14 semanas, sendo também superiores aos teores registrados por Cook \& Mulder (1984b). Os teores de enxofre nas folhas atenderiam apenas as exigências nutricionais de bovinos de corte (NRC, 1984)

\subsubsection{Micronutrientes}

Os teores de micronutrientes nas folhas de Paspalum coryphaeum NO 174 em crescimento são apresentados na figura 18. Os teores de boro, cobre, manganês e zinco variaram de forma quadrática com os intervalos de crescimento, enquanto que para os teores de ferro a resposta foi linear.

Os teores de boro e de cobre apresentaram o mesmo comportamento, decrescendo inicialmente para em seguida tenderem à elevação. $O$ teor de boro era de $3,2 \mathrm{mg} \mathrm{kg}^{-1}$ após 4 semanas, atingiu $1,8 \mathrm{mg} \mathrm{kg}^{-1}$ com 14 semanas, para em seguida alcançar $4,3 \mathrm{mg} \mathrm{kg}^{-1}$ com 22 semanas. Para o cobre, após 4 semanas o teor nas folhas verdes era de $11,7 \mathrm{mg} \mathrm{kg}^{-1}$, decrescendo em seguida para $8,7 \mathrm{mg} \mathrm{kg}^{-1}$ com 8 semanas, após o que, não experimentou variações acima de $1 \mathrm{mg} \mathrm{kg}^{-1}$.

Para o manganês e para o zinco as concentrações nas folhas verdes foram crescentes até 14 semanas, mas em seguida, tenderam a diminuir. $O$ teor de manganês elevou-se de $253 \mathrm{mg} \mathrm{kg}^{-1}$, com 4 semanas, para $378 \mathrm{mg} \mathrm{kg}^{-1}$, com 8 semanas, diminuindo para $334 \mathrm{mg} \mathrm{kg}^{-1}$ após 22 semanas. $O$ teor de zinco era de $26 \mathrm{mg} \mathrm{kg}^{-1}$ com 4 semanas, alcançou $39 \mathrm{mg} \mathrm{kg}^{-1}$ com 14 semanas, para em seguida situar-se em $33 \mathrm{mg} \mathrm{kg}^{-1}$, após 22 semanas. Por sua vez, o teor de ferro decresceu numa taxa média de $3,5 \mathrm{mg} \mathrm{kg}^{-1}$ semana $^{-1}$, sendo estimado em 143 $\mathrm{mg} \mathrm{kg}^{-1}$ com 4 semanas, e $80 \mathrm{mg} \mathrm{kg}^{-1}$, após 22 semanas. 


$$
\begin{array}{lll}
B & Y=4,5-0,53 X+0,024 X^{2} & R^{2}=0,53 \\
\mathrm{Cu} & Y=10-0,81 X+0,026 X^{2} & R^{2}=0,57 \\
\mathrm{Fe} & Y=157-3,5 X & R^{2}=0,55 \\
\mathrm{Mn} & Y=162+29,4 X-0,99 X^{2} & R^{2}=0,37 \\
\mathrm{Zn} & Y=17-2,8 X-0,096 X^{2} & R^{2}=0,40 \\
& & n=15 P<0,05
\end{array}
$$

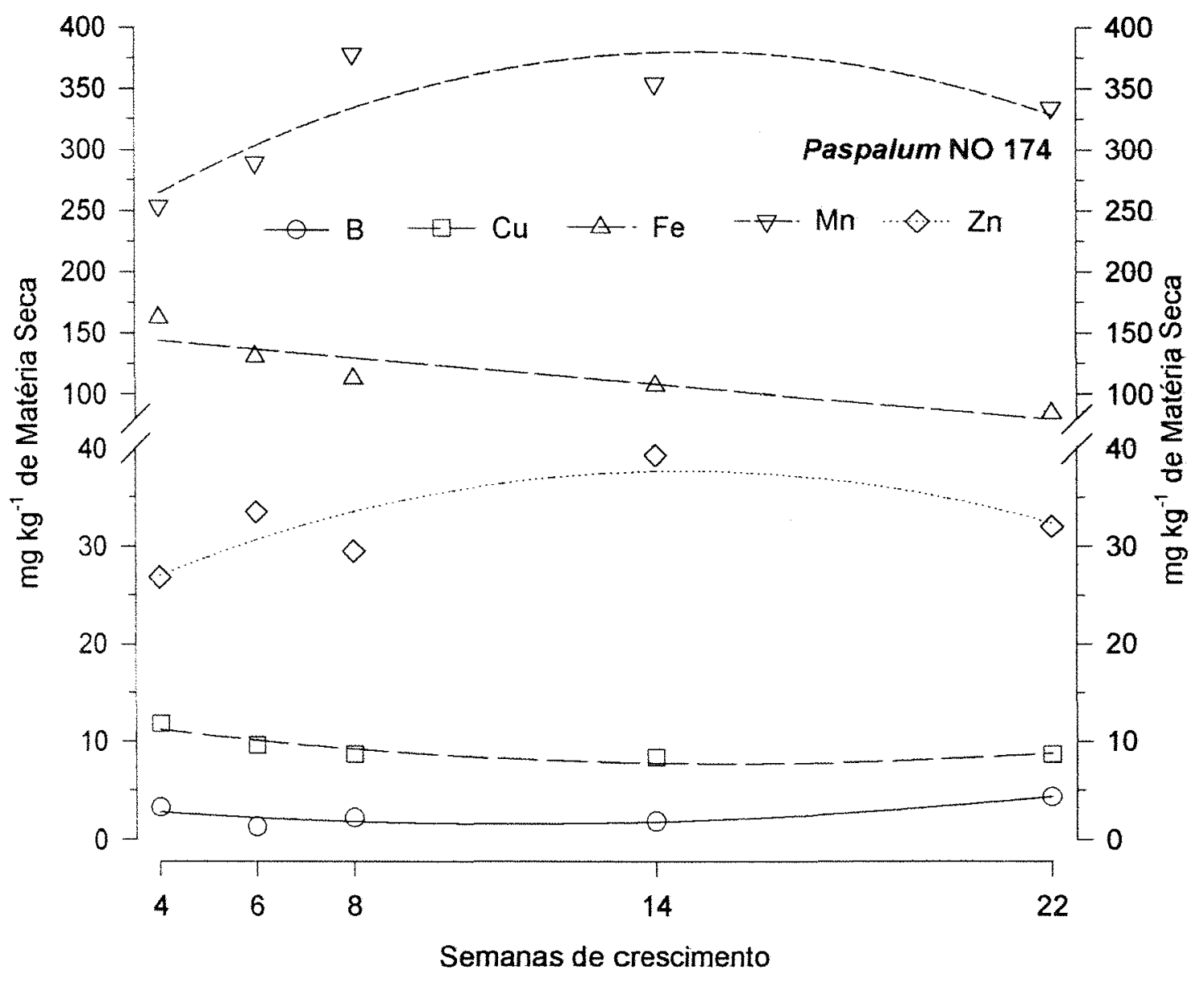

Figura 18. Teores de micronutrientes nas folhas, colmos $(-c)$ e na forragem (-forv) do Paspalum coryphaeum NO 174 em períodos de crescimento no início da estação chuvosa. Nova Odessa, SP. 
Os teores de manganês, zinco e cobre foram superiores aos relatados por Gallo et al. (1974), enquanto os de boro foram inferiores, bem como os teores de ferro, exceto para 4 semanas de crescimento. 


\section{CONCLUSÕES}

Para as condições em que foram conduzidas este trabalho pode-se concluir que no crescimento ao início da estação chuvosa:

A produção de forragem nas gramíneas Panicum maximum cultivar Aruana, Panicum maximum cultivar IZ-1 e Paspalum coryphaeum Trin. NO 174 ocorre com a participação relativa crescente de colmos e material senescido, e decrescente para as folhas;

Em 22 semanas de crescimento a disponibilidade de folhas na forragem é crescente para o Panicum maximum cultivar $I Z-1$, enquanto que para - Panicum maximum cultivar Aruana e para o Paspalum coryphaeum NO 174 é decrescente após um limite de tempo;

A densidade de perfilhos diminui com o aumento no intervalo de crescimento sem desfolhas no Panicum maximum cultivar Aruana e no Panicum maximum cultivar $\mid Z-1$, enquanto que no Paspalum coryphaeum Trin. NO 174 não apresenta variações significativas;

Desfolhas efetuadas após 8 semanas de crescimento reduzem a produtividade da rebrota subsequente;

Os teores dos nutrientes minerais nas folhas apresentam comportamento diferenciado com o crescimento;

Para maior rendimento da forragem acumulada e da rebrota subsequente, as desfolhas deverão ocorrer no máximo após 8 semanas de crescimento, no início da estação chuvosa, para o Panicum maximum cultivar 
Aruana e para o Paspalum coryphaeum NO 174, enquanto que para o Panicum maximum cultivar $\mathrm{Z}$-1 pode se estender por até 14 semanas de crescimento. 


\section{REFERÊNCIAS BIBLIOGRÁFICAS}

ALCÃNTARA, P. B.: PEDRO Jr.. M. J.; DONZELLI. P. L. Zoneamento edafoclimático de plantas forrageiras. In. FAVORETTO, V.; RODRIGUES, L. R. de A.; REIS, R. A. (Ed.) SIMPÓSIO SOBRE ECOSSISTEMA DE PASTAGENS, 2., Jaboticabal, SP, 1993. Anais. Jaboticabal: FUNEP, 1993. p. 1-16.

ALCÂNTARA, V. de B. G.; ALMEIDA, A. R. P. de; GHISI, O. M. A. A. Estudos fisiológicos de seis cultivares de Panicum maximum Jacq. Boletim da Indústria Animal, v.42, n.2, p. 199208, 1985

ALCÂNTARA, V. B. G.: ALMEIDA, A. R. P de: GHISI. O. M. A. A. Algumas medidas morfofisiológicas em seis cultivares de Panicum maximum Jacq. Revista de Agricultura, v.66, n.1, p. 47-63, 1991.

ALLEM, A. C; VALLS. J. F. M. Recursos forrageiros nativos do pantanal matogrossense. Brasília: EMBRAPA, 1987. 339p. (EMBRAPA-CENARGEN - Documentos, 8).

ANDRADE, J. B. de. Estudo comparativo de três capins da espécie Panicum maximum Jacq. (Colonião, Tobiatã e K-187 B). Piracicaba. 1987. 133p. Dissertação (Mestrado) - Escola Superior de Agricultura "Luiz de Queiroz", Universidade de São Paulo.

ANDRADE, J. B.; PEDREIRA. J. V. S.; HENRIQUE, W. Comparação de três capins da espécie Panicum maximum Jacq. (Colonião. Tobiatã e K-187 B) sob dois niveis de adubação nitrogenada. Boletim da Indústria Animal, v.48, n.2, p. 77-82, 1991.

ANDRADE, R. P. Tecnologia de produção de sementes de espécies do gênero Brachiaria. In: PEIXOTO, A. M.: MOURA. J. C. de; FARIA. V. P. de (Ed.) SIMPÓSIO SOBRE MANEJO DA PASTAGEM, 11. Piracicaba, SP, 1994. Anais. Piracicaba: FEALQ, 1994. p. 49-72. 
ANDREW, C. S.; ROBINS, M. F. The effect of phosphorus on the growth, chemical composition, and critical phosphorus percentages of some tropical pasture grasses. Australian Journal of Agricultural Reseach, v.22, n.3, p. 693-706, 1971.

ANÔNIMO. Capim-Aruana. Comunicação da Pesquisa Agropecuária, v.12, n.3, p. 22, 1994.

ANSLOW, R. C. The rate of appearance of leaves on tillers of the gramineae. Herbage Abstracts, v.36, n. 3, p. 149-155, 1966.

ARAÚJO, A. A. Principais gramineas do Rio Grande do sul. Porto Alegre: Editora Sulina, 1971. $255 p$.

ARONOVICH, S. O capim colonião e outros cultivares de Panicum maximum (Jacq.): Introdução e evolução do uso no Brasil. In: PEIXOTO, A. M.; MOURA, J. C. de; FARIA, V. P. de (Ed.) SIMPÓSIO SOBRE MANEJO DA PASTAGEM, 12., Piracicaba, SP, 1995. Anais. Piracicaba: FEALQ, 1995. p. 1-20.

ARROYO-AGUILÚ, J. A.; COWARD-LORD, J. Mineral composition of 10 tropical forage grasses in Puerto Rico. The Journal of Agriculture of the University of Puerto Rico, v. 58, n. 4, p. $426-436,1974$.

BATISTA, L. A. R; GODOY, R. Caracterização de germoplasma do gênero Paspalum na Região Central do Estado de São Paulo - Brasil. I - Características vegetativas. In: PIZARRO. E. A. (Ed.) RED INTERNACIONAL DE EVALUACIÓN DE PASTOS TROPICALES - REUNIÓN SABANAS, 1., Brasilia, DF, 1992. Memórias. Cali, Brasília: CIAT, EMBRAPA-CPAC, 1992a. p. 97-105 (CIAT - Documento de trabajo, 117).

BATISTA, L. A. R; GODOY, R. Introdução e avaliação do potencial forrageiro em germoplasma do gênero Paspalum na região de São Carlos, São Paulo. In: PIZARRO. E. A. (Ed.) RED INTERNACIONAL DE EVALUACIÓN DE PASTOS TROPICALES - REUNIÓN SABANAS, 1. Brasilia, DF, 1992. Memórias. Cali, Brasilia: CIAT, EMBRAPA-CPAC, 1992b. p. 239-245 (CIAT - Documento de trabajo, 117).

BATISTA, L. . A. R.; GODOY, R.; PEREIRA, J. M. C. Avaliação do potencial forrageiro de espécies do gênero Paspalum. Ensaio 1992/93. In: REUNIÃO ANUAL DA SOCIEDADE BRASILEIRA DE ZOOTECNIA, 31., Maringá, PR, 1994. Anais. Maringá: Sociedade Brasileira de Zootecnia, 1994. p 641.

BENEDETTI, E.; RODRIGUEZ, N. M.; GONÇALVES, L. C. Avaliação de forrageiras tropicais. II. Estudo do potencial nutritivo das folhas e caules de três espécies forrageiras. In: 
REUNIÃO ANUAL DA SOCIEDADE BRASILEIRA DE ZOOTECNIA, 31., Maringá, PR, 1994. Anais. Maringá: Sociedade Brasileira de Zootecnia, 1994. p 269.

BLASER, R. E. Manejo do complexo pastagem-animal para avaliação de plnatas e desenvolvimento de sistemas de produção de forragem. In: Pastagens. Piracicaba: Sociedade brasileira de Zootecnia, FEALQ, 1990. p. 157-205.

BOIN, C. Exigências minerais pelas categorias do rebanho bovino e funçōes desses nutrientes. In: SIMPÓSIO SOBRE NUTRIÇÃO DE BOVINOS, 3., Piracicaba, SP, 1985. Anais. Piracicaba: FEALQ, 1985. p. $15-46$.

BOIN, C. Produção animal em pastos adubados. In: MATTOS, H. B.; WERNER, J. C.; YAMADA, T. (Ed.) SIMPÓSIO SOBRE CALAGEM E ADUBAÇÃO DE PASTAGENS, 1., Nova Odessa, SP, 1985. Anais. Piracicaba: POTAFOS, 1986. p. 383-419.

BROWN, W. E.; SPIERS, J. M.; THURMAN, C. W. Performance of five warm-season perennial grasses grown in southern Mississippi. Agronomy Journal, v. 68, p. 821-823, 1976.

CARRIEL, J. M.; PEDREIRA, J. V. S.; MATTOS, H. B. Estimativa da ocorrência dos principais capins do Estado de São Paulo. Zootecnia, v.17, n.1, p. 5-25, 1979.

CARVALHO, M. A.; PIZARRO, E. A.; VALLS, J. F. M.; MACIEL, D. Paspalum plicatulum: Evaluación agronómica de ecótipos en el Cerrado. In: PIZARRO. E. A. (Ed.) RED INTERNACIONAL DE EVALUACIÓN DE PASTOS TROPICALES - REUNIÓN SABANAS, 1., Brasilia, DF, 1992. Memórias. Cali, Brasilia: CIAT, EMBRAPA-CPAC, 1992. p. 247-250 (CIAT - Documento de trabajo, 117).

CERRI, C. C. Dinâmica da matéria orgância em solos de pastagem. In: FAVORETTO, V; RODRIGUES, L. R. de A. (Ed.) SIMPÓSIO SOBRE ECOSSISTEMA DE PASTAGENS, 1. Jaboticabal, SP, 1989. Anais. Jaboticabal: FUNEP, 1989. p. 135-147.

COOK, B. G.; MULDER, J. C. Responses of nine tropical grasses to nitrogen fertilizer under rain-grown conditions in south-eastern Queensiand. 1. Seasonal dry matter productivity. Australian Journal of Experimental Agriculture and Animal Husbandry, v.24, n.126, p. 410-414, 1984a.

COOK, B. G.; MULDER, J. C. Responses of nine tropical grasses to nitrogen fertilizer under rain-grown conditions in south-eastern Queensland. 2. Concentrations and uptakes of nitrogen, phosphorus and potassium in plant tops. Australian Journal of Experimental Agriculture and Animal Husbandry, v.24, n.126, p. 415-420, 1984b. 
COOPER, J. P. Potential production and energy conversion in temperate and tropical grasses. Herbage Abstracts, v. 40, n.1, p. 1-15, 1970.

COOPER, J. P.; TAINTON, N. M. Light and temperature requirements for the growth of tropical and temperate grasses. Herbage Abstracts, v.38, n.3, p. 167-176, 1968.

CORSI, M. Estudo da produtividade e do valor nutritivo do capim elefante (Pennisetum purpureum, Schum.) variedade Napier submetido a diferentes frequências e alturas de corte. Piracicaba, 1972. 139p. Tese (Doutorado) - Escola Superior de Agricultura "Luiz de Queiroz", Universidade de São Paulo.

CORSI, M. Pastagens de alta produtividade. In: PEIXOTO, A. M.; MOURA, J. C. de; FARIA, V. P. de (Ed.) SIMPÓSIO SOBRE MANEJO DA PASTAGEM, 8., Piracicaba, SP, 1986. Anais. Piracicaba: FEALQ, 1986. p. 499-512.

CORSI. M.; SILVA, R. T. de L. e. Fatores que afetam a composição mineral de plantas forrageiras. In: SIMPÓSIO SOBRE NUTRIÇÃO DE BOVINOS, 3., Piracicaba, SP, 1985. Anais. Piracicaba: FEALQ, 1985. p. 1-14.

CORSI. M; BALSALOBRE, M. A; SANTOS, P. M; SILVA, S. C. da. Bases para o estabelecimento do manejo de pastagens de Brachiaria. In: PEIXOTO, A. M; MOURA, J. C. de; FARIA, V. P. de (Ed.) SIMPÓSIO SOBRE MANEJO DA PASTAGEM, 11., Piracicaba, SP, 1994. Anais. Piracicaba: FEALQ, 1994. p. 249-266.

COSENTINO, J. R.; ABRAMIDES, P. L. G.; MEIRELLES, N. M. F.; PEDREIRA, J. V. S. Vinte anos de observações meteorológicas em Nova Odessa-SP. Zootecnia, v.26, n.4, p. 205-217, 1988.

COSTA, N. de L.; GONÇALVES, C. A.; OlIVEIRA, J. R. da C.; OLIVEIRA, M. A. S. Rendimento de gramíneas em Ariquemes - RO. Porto Velho: UEPAE Porto Velho, 1988. 4p. (EMBRAPA-UEPAE Porto Velho. Comunicado Técnico, 63).

COSTA, N. de L.; GONÇALVES, C. A.; OLIVEIRA, M. A. S.; OLIVEIRA; J. R. C. Introdução e avaliação de gramíneas forrageiras em Porto Velho-RO. Porto Velho: EMBRAPA-UEPAE Porto Velho, 1989a. 4p. (EMBRAPA-UEPAE Porto Velho. Comunicado Técnico, 74)

COSTA, N. de L.; OLIVEIRA, J. R. C.; GONÇALVES, C. A. Avaliação agronômica de gramineas forrageiras em Rondônia, Brasil. Pasturas Tropicales, v.11, n.3, p. 21-24, $1989 \mathrm{~b}$.

COSTA N. de L.; OLIVEIRA, J.R. da C. Avaliação agronômica de gramíneas forrageiras do gênero Paspalum em Rondônia. Porto Velho: CPAF-Rondônia, 1992, 7 p. (EMBRAPACPAF-Rondônia. Comunicado Técnico, 104). 
COSTA, N. de L; OLIVEIRA, J.R. da C. Avaliação agronômica de gramíneas forrageiras do gênero Paspalum em Rondônia. Lavoura Arrozeira, v.47, n.412, p. 18-20, 1994.

COWARD-LORD, J.; ARROYO-AGUILÚ, J. A.; GARCIA-MOLINARI, O. Proximate nutrient composition of 10 tropical forage grasses. The Journal of Agriculture of the University of Puerto Rico, v.58, n.3, p. 305-311, 1974.

EUCLIDES, V. P. B.; ZIMMER, A. H.; VIEIRA, J. M. Equilibrio na utilização da forragem sob pastejo. In: FAVORETTO, V.; RODRIGUES, L. R. de A. (Ed.) SIMPÓSIO SOBRE ECOSSISTEMA DE PASTAGENS, 1., Jaboticabal, SP, 1989. Anais. Jaboticabal: FUNEP, 1989. p. 271-313.

EVANS, T. R. Overcoming nutritional limitations through pasture management. In: Nutritional limits to amimal production from pastures. In: HACKER, J. B. (Ed.) Nutritional limits to animal production from pastures. St. Lucia, 1981. St. Lucia: Farnham Royal, Commonwealth Agricultural Bureaux, 1982. p. 343-361.

FERRARI JR., E. Utilização do capim-colonião IZ-1 para a produção de feno. Comunicação da Pesquisa Agropecuária, v.12, n.3, p. 19, 1994.

FORBES, T. D. A. Researching the plant-animal interface: the investigation of ingestive behavior in grazing animals. Joumal of Animal Science, v.66, p. 2369-2379, 1988.

FRANÇA, A. F. S.; HAAG, H. P. Nutrição mineral de gramíneas tropicais. I Carências nutricionais de capim tobiatã (Panicum maximum Jacq.). Anais da Escola Superior de Agricultura "Luiz de Queiroz", v.42, n.1, p. 83-95, 1985.

FRANÇA, A. F. S.; HAAG, H. P. Nutrição mineral de gramíneas tropicais. II Carências de micronutrientes em capim tobiatã (Panicum maximum, Jacq.). Anais da Escola Superior de Agricultura "Luiz de Queiroz", v.43, n.2, p. 537-550, 1986.

FRANÇA-DANTAS, M. S.; ANDRADE, R. P. de; GROF, B.; ZOBY, J. L. F.; KORNELIUS, E.; SOUZA, F. B. de. Relato dos projetos de seleção de Paspalum para os cerrados. In: SAVIDAN, Y; ALCÂNTARA, P. B.; VALLS, J. F. M.; QUARÍN, C.; ALMEIDA, A. R. P. de (Ed.) ENCONTRO INTERNACIONAL SOBRE MELHORAMENTO DO GÊNERO PASPALUM. Nova Odessa, SP, 1987. Anais. Nova Odessa: Instituto de Zootecnia, 1987. p. $15-21$.

FRANK, A. B.; RIES, R. E. Effect of soil water, nitrogen, and growing degree-days on morphological development of crested and western wheatgrass. Joumal of Range Management, v.43, p. 257-260, 1990. 
GALLO, J. R.; HIROCE, R.; BATAGLIA, O. C.; FURLANI, P.R.; FURLANI, A. M. C.; MATTOS, H. B. de; SARTINI, H. J.; FONSECA, M. P. Composição inorgânica de forrageiras do Estado de São Paulo. Boletim de Indústria Animal, v.31, n.1, p. $\uparrow 15-137,1974$.

GEORGE, M. R.; CLAWSON, W. J.; WILSON, C. B.; WILLOUGHBY, R. L.; MCDOUGALD, N. K. Correlation of degree-days with herbage yields on california's annual grasstands. In: INTERNATIONAL GRASSLAND CONGRESS, 16., Nice, 1989. Proceedings. Nice: IGS, 1989 , v.2. p. $1365-1366$

GHELFI FILHO, H. Efeito da irrigação sobre a produtividade do capim elefante Pennisetum purpureum, Schum., variedade Napier. Piracicaba, 1972. 77p. Tese (Doutorado) - Escola Superior de Agricultura "Luiz de Queiroz", Universidade de São Paulo.

GHISI, O. M. A. A.; ALMEIDA, A. R. P. de; ALCÂNTARA, V. de B. G. Avaliação agronômica de seis cultivares de Panicum maximum Jacq. sob três niveis de adubação. Boletim da Indústria Animal, v.46, n.1, p. 1-15, 1989.

GOMIDE, J. A. Manejo de pastagens para a produção de leite. In: CECATO, U.; SANTOS, G. T.; PRADO, I. N.; MOREIRA, I. (Ed.) SIMPÓSIO INTERNACIONAL DE FORRAGICULTURA, Maringá, PR, 1994. Anais. Maringá: EDUEM, 1994. p. 141-168.

GOMIDE, J. A;ZAGO, C. P. Crescimento e recuperação do capim-colonião após corte. Revista da Sociedade Brasileira de Zootecnia, v.9, n.2, p. 293-305, 1980.

GOMIDE, J. A.;OBEID, J. A.;RODRIGUES, L. R. A. Fatores morfofisiológicos da rebrota do capimcolonião (Panicum maximum). Revista da Sociedade Brasileira de Zootecnia, v.8, n.4, p. $533-562,1979$.

GOMIDE, J. A.; HOLLER, C. H.; MOTT, G. O.; CONRAD, J. H.; HILL, D. L. Mineral composition of six tropical grasses as influenced by plant age and nitrogen fertilization. Agronomy Journal, v. 61, n. 1, p. 120-123, 1969.

HACKER, J. B. \& MINSON, D. J. The digestibility of plant parts. Herbage Abstracts, v.51, n.9, p. 459-482, 1981.

HARRIS, W. Defoliation as a determinant of the growth, persistence, and composition of pasture. In: WILSON, J. R. (Ed.) Plant relations in pastures. Melbourne: CSIRO, 1978. p. 67-84.

HARRIS, W.; FORDE;B. J.,HARDACRE, A. K. Temperature and cutting effects on the growth and competitive interaction of ryegrass and paspalum. 1. Dry matter production, tiller numbers, and light interception. New Zealand Journal of Agricultural Research, v. 4, n.3/4, p. 299-307, 1981. 
HILLESHEIM, A. Fatores que afetam o consumo e perdas de capim-elefante (Pennisetum purpureum Schum.) sob pastejo. Piracicaba, 1987. 94 p. Dissertação (Mestrado) - Escola Superior de Agricultura "Luiz de Queiroz", Universidade de São Paulo.

HODGSON, J.; BIRCHAM, J. S.;GRANT, S. A.;KING, J. The influece of cutting and grazing management on herbage growth and utilisation. In: WRIGHT, C. E. (Ed.) Plant physiology and herbage production. Occasional Symposium No 13. Maindenhead: British Grassland Society, 1981, p. $51-62$.

HOLMES, W. Grazing management. In: HOLMES, W. (Ed.) Grass: its production and utilization. Oxford: Blackwell Scientific Publications, 1989. cap. 4, p. 130-171.

HUNT, R. Plant growth curves. London: Edward Arnold, 1982. 248 p.

INSTITUTO DE ZOOTECNIA. "Capim Aruana" ( Panicum maximum cv. Aruana IZ-5). Folder de pré-lançamento. Nova Odessa: Instituto de Zootecnia, 1989.

JANK, L. Potencial do gênero Panicum. In: BUTOLO, J. E. (Ed.) SIMPÓSIO BRASILEIRO DE FORRAGEIRAS E PASTAGENS, Campinas, SP, 1994. Anais. Campinas: CBNA, 1994. p. 2532.

JARREL, W. M. \& BEVERLY, R. B. The dilution effects in plant nutrition studies. Advances in Agronomy, v.34, n.1, p. 197-224, 1981.

JOLLIFFE, P. A.; TARIMO, A. J. P.; EATON, G. W. Plant growth analysis: growth and yield component responses to population density in forage maize. Annals of Botany, v. $65, n .2$, p. $139-147,1990$

JONES, R. M. Some thoughts on comparing the quality of different pasture species. Tropical Grasslands, v.26, n.1, p. 74-75, 1992.

KAYONGO-MALE, H.; THOMAS, J. W.; ULLREY, D. E.; DEANS, R. J.; ARROYO-AGUILÚ, J. A. The Journal of Agriculture of the University of Puerto Rico, v.60, n.2, p. 187-200, 1976.

LANGER, R. H. M. Changes in the tiller population of grass swards. Nature, v.182, n.4652, p. $1817-18,1958$.

LANGER, R. H. M. How grasses grow. London: Edward Arnold, 1974. 66p.

LANGER, R. H. M. Tillering in herbage grasses. Herbage Abstracts, v.33, n.3, p. 141-148, 1963. 
LAUDE, H. M. External factors affecting tiller development. In: YOUNGNER, V. B.; McKELL, C. M. (Ed.) The biology and utilization of grasses. New York: Academic Press, 1972. p. 146-153.

LEPSCH, I. F. Influência dos fatores edáficos na produção. In: CASTRO, P. R. C.; FERREIRA, S. O.; YAMADA, T. (Ed.) Ecofisiologia da produção agrícola. Piracicaba: POTAFOS, 1987. p. 83-100.

LIMA, R. R.; GONDIM, A. G. Avaliação de forrageiras nativas especialmente do gênero Paspalum. Belém: Faculdade de Ciências Agrárias do Pará, 1982. 41p. (FCAP - Informe Técnico, 9).

LOMBARDI NETO, F. Degradação das pastagens: In: PAULINO, V. T; ALCÂNTARA, P. B. (Coord.) ENCONTRO SOBRE RECUPERAÇÃO DE PASTAGENS, 1., Nova Odessa, SP, 1993. Anais. Nova Odessa, SP: Instituto de Zootecnia, 1993. p. 49-60.

LUDLOW, M. M. Light relations of pasture plants. In: WILSON, J. R. (Ed.) Plant relations from pastures. Melbourne: CSIRO, 1978. p. 35-49.

't MANNETJE, L.; EBERSOHN, J. P. Relations between sward characteristics and animal production. Tropical Grasslands, v.14, n.3, p. 273-280, 1980.

MARASCHIN, G. E. Perdas de forragem sob pastejo. In: FAVORETTO, V.; RODRIGUES, L. R. de A.; REIS, R. A. (Ed.) SIMPÓSIO SOBRE ECOSSISTEMA DE PASTAGENS, 2., Jaboticabal, SP, 1993. Anais. Jaboticabal: FUNEP, 1993. p. 166-190.

MARASCHIN, G. E. Sistemas de pastejo 1. In: PEIXOTO, A. M.; MOURA, J. C. de; FARIA, V. P. de (Ed.) SIMPÓSIO SOBRE MANEJO DA PASTAGEM, 8., Piracicaba, SP, 1986. Anais. Piracicaba: FEALQ, 4986. p. 264-290.

MARTINEZ, H. E. P. Niveis críticos de fósforo em Brachiaria decumbens (Stapf.) Praia, Brachiaria humidicola (Rendle) Schweickerdt, Digitaria decumbens Stent, Hyparthenia rufa (Ness) Stapf, Melinis minutiflofa Pal de Beauv, Panicum maximum Jacq. e Pennisetum purpureum Schum. Piracicaba, 1980. 90p. Dissertação (Mestrado) - Escola Superior de Agricultura "Luiz de Queiroz", Universidade de São Paulo.

MARTINEZ, M.; GONZÁleZ, Y.; ALFONSO, A. Paspalum spp. Pastos y Forrages, v.8, n.2, p. $157-189,1985$

MATTOS, H. B. de; COLOZZA, M. T. Micronutrientes em pastagens. In: MATTOS, H. B.; WERNER, J. C.; YAMADA, T. (Ed.) SIMPÓSIO SOBRE CALAGEM E ADUBAÇÃO DE PASTAGENS, 1., Nova Odessa, SP, 1985. Anais. Piracicaba: POTAFOS, 1986. p. 233-255. 
MATTOS, H. B. de; WERNER, J. C. Efeito do nitrogênio mineral e de leguminosas sobre a produção do capim-colonião (Panicum maximum Jacq.). Boletim da Indústria Animal, v.36, n.1. p. $147-156,1979$

MEIRELLES, N. M. F.; WERNER, J. C.; ABRAMIDES, P. L. G.; CARRIEL, J. M.; PAULINO, V. T.; COLOZZA, M. T. Nível crítico de fósforo em capim-colonião cultivado em dois tipos de solo: Latossolo Vermelho-Escuro e Podzólico Vermelho-Amarelo. Boletim da Indústria Animal, v.45, n.1, p. 215-232, 1988.

MIDDLETON, C. H. Dry matter and nitrogen changes in five tropical grasses as influenced by cutting heigth and frequency. Tropical Grasslands, v. 16, n.2, p. 112-117, 1982.

MINSON, D. J. Nutritional differences between tropical and temperate pastures. In: MORLEY, F. W. (Ed.) Grazing animals. World animal science. Netherland: Elsevier, 1981. p. 143157.

MINSON, D. J. Forage in ruminant nutrition. San Diego: Academic Press, 1990. 483p.

MINSON, D. J. Composición química y valor nutritivo de las gramíneas tropicales. In: SKERMAN, P. J.; RIVEROS, F. Gramíneas tropicales. Roma: FAO, 1992. p. 181-199.

MONTEIRO, F. A; WERNER, J. C. Ciclagem de nutrientes minerais em pastagens. In: FAVORETTO, V.; RODRIGUES, L. R. de A. (Ed.) SIMPÓSIO SOBRE ECOSSISTEMA DE PASTAGENS, 1., Jaboticabal, SP, 1989. Anais. Jaboticabal: FUNEP, 1989. p. 150-192.

NRC - NATIONAL RESEARCH COUNCIL. Sub committee on dairy cattle nutrition, Committee on animal nutrition, Board on agriculture, National Research Council. Nutrient requeriments of dairy cattle. 6th rev. ed. 1988. Washington: National Academy Press, 1988. 157p. (Nutrient Requirements of Domestic Animals).

NRC - NATIONAL RESEARCH COUNCIL. Sub committee on beef cattle nutrition. Nutrient requeriments of beef cattle. 6a. ed. Washington: National Academy Press, 1984. 90p. (Nutrient Requirements of Domestic Animals).

NRC - NATIONAL RESEARCH COUNCIL. Sub committee on dairy cattle nutrition. Nutrient requeriments of dairy cattle. 5a. ed. Washington: National Academy of Sciences, 1978. 76p. (Nutrient Requirements of Domestic Animals).

OLIVEIRA. M. A. S; ALVES, P. M. P. Novas opções de gramíneas no controle da cigarrinha-das-pastagens em Rondônia. Porto Velho: UEPAE Porto Velho, 1988. 18 p. (EMBRAPA-UEPAE Porto Velho. Boletim de Pesquisa, 9). 
OLIVEIRA, M. A. S.; GONÇALVES, C. A.; ALVES, P. M. P. Brizantão, Tobiatã, Andropogon e Paspaluns nativos, novas opções de gramíneas no controle da cigarrinha das pastagens em Rondônia. Porto Velho: UEPAE Porto Velho, 1984. 11p. (EMBRAPAUEPAE Porto Velho. Comunicado Técnico, 33).

OMALIKO, C. P. E. Influence of initial cutting date and cutting frequency on yield and quality of star, elephant and Guinea grasses. Grass and Forage Science, v.35, n.2, p. 139-145, 1980.

PARSONS, A. J. New light on the grass sward and the grazing animal. In: DONALDSON, W. A. LISTER, D. (Ed.) Annual report 1985-86. Animal and Grassland Research Institute. Hurley: AGRI, 1988. p. 90-95.

PAULINO, V. T.; PACOLA, L. J.; BUFARAH, G. Competição de plantas forrageiras cultivadas num latossolo roxo de Sertãozinho, SP. Boletim da Indústria Animal, v.47, n.2, p. 133$139,1990$.

PEDREIRA, J. V. S. Crescimento estacional dos capins colonião (Panicum maximum Jacq.); gordura (Melinis minutiflora Pal de Beauv), jaraguá (Hyparrhenia rufa (Ness) Stapf) e Pangola de Taiwan A-24 (Digitaria pentzii Stent.). Piracicaba, 1972. 117p. Tese (Doutorado) - Escola Superior de Agricultura "Luiz de Queiroz", Universidade de São Paulo.

PEDREIRA, J. V. S. Hábitos de perfilhamento do capim-colonião Panicum maximum Jacq. Boletim da Indústria Animat, v. 32, n. 1, p. 111-114, 1975.

PEDREIRA, J. V. S.; SILVEIRA, J. J. N. Variação da composição bromatológica do capim colonião Panicum maximum Jacq. Boletim de Indústria Animal, v.26, n.1, p. 185-190, 1972.

PINTO. H. S.; SÁ, T. D. Fluxo de energia e eficiência de conversão na produção de forragem. 1989 In: FAVORETTO, V.; RODRIGUES, L. R. de A. (Ed.) SIMPÓSIO SOBRE ECOSSISTEMA DE PASTAGENS, 1., Jaboticabal, SP, 1989. Anais. Jaboticabal: FUNEP, 1989. p. 1-30.

PIZARRO, E. A. \& CARVALHO, M. A. Cerrado: Introducción y evaluación agronómica de forrajeras tropicales. In: PIZARRO. E. A. (Ed.) RED INTERNACIONAL DE EVALUACIÓN DE PASTOS TROPICALES - REUNIÓN SABANAS, 1., Brasília, DF, 1992. Memorias. Cali, Brasilia: CIAT, EMBRAPA-CPAC, 1992. p. 1-68 (CIAT - Documento de trabajo, 117).

POTT. A. As pastagens no pantanal. Corumbá: EMBRAPA-CPAP, 1988. 58p. (EMBRAPACPAP. Documentos, 7 ).

PRATES, E. R. Efeito de doses de nitrogênio e de intervalos entre cortes sobre a produção e composição de dois ecotipos de Paspalum notatum Flügge e da cultivar Pensacola Paspalum 
notatum Flügge var. saurae Parodi. Porto Alegre, 1970. 56p. Dissertação (Mestrado) Faculdade de Agronomia, Universidade Federal do Rio Grande do Sul.

RAIJ, B. Van. Fertilidade do solo e adubação. São Paulo/Piracicaba: Editora Agronômica Ceres/ POTAFOS, $1991.343 p$.

ROBSON, M. J.; PARSONS, A. J.; WILLIAMS, T. E. Herbage production: grasses and legumes. In: HOLMES, W. (Ed.) Grass: its production and utilization. Oxford: Blackwell Scientific Publications, 1989. cap. 2, p. 7-88.

ROCHA, G. L. da. Ecossistema de pastagens: Aspectos dinâmicos. Piracicaba: FEALQ, 1991. $391 p$.

RODRIGUES, L. R. de A. Espécies forrageiras para patagens: gramineas In: PEIXOTO, A. M.; MOURA, J. C. de; FARIA, V. P. de (Ed.) SIMPÓSト SOBRE MANEJO DA PASTAGEM, 8. Piracicaba, SP, 1986. Anais. Piracicaba: FEALQ, 1986. p. 375-388.

RODRIGUES, L. R. de A.; RODRIGUES, T. de J. D. Ecofisiologia de plantas forrageiras. In: CASTRO, P. R. C.; FERREIRA, S. O; YAAADA, T. (Ed.) Ecofisiologia da produção agrícola. Piracicaba: POTAFOS, 1987. p. 203-230.

RODRIGUES, T. de J. D.; RODRIGUES, L. R. de A.; REIS, R. A. Adaptação de plantas forrageiras às condições adversas. If;: FAVOREFFO, V.; RODRIGUES, L. R. de A. (Ed.) SIMPÓSIO SOBRE ECOSSISTEMA DE PASTAGENS, 2,, Jaboticabal, SP, 1993. Anais. Jaboticabal: FUNEP, 1993. p. $17-61$.

RODRIGUEZ, N. M.; BENEDETTI, E.; GONÇALVES, L. C. Avaliação de forrageiras tropicais. II. Comportamento nutricional de três espécies de gramíneas no cerrado do triângulo mineiro. In: REUNIÃO ANUAL DA SOCIEDADE BRASILEIRA DE ZOOTECNIA, 31., Maringá, PR, 1994. Anais. Maringá: Sociedade Brasileira de Zootecnia, 1994. p 268.

SANDERSON, M. A; WOLF, D. D. Morphological development of switchgrass in diverse environments. Agronomy Joumat, v:87, n:5, 1995

SANTOS FILHO, L. F. Diagnóstico da situação da produção de sementes de plantas forrageiras no Estado de São Paulo. In: PERES, R. M; ALCÂNTARA, P. B. JUSTO, C. (Ed.) ENCONTRO SOBRE PRODUÇÃO DE SEMENTES DE PLANTAS FORRAGEIRAS, 4., São José do Rio Preto, SP, 1990. Anais. São José do Rio Preto: Gráfica Só-cópias, 1990. p. $1-14$.

SARRUGE, J. R. \& HAAG, H. P. Análises químicas em plantas. Piracicaba: ESALQ, 1984. 49p. 
SAS Institute Inc. SASISTAT User's Guide, Release 6.03 Edition. Cary, NC: SAS Institute Inc., 1988. $1028 p$.

SAVIDAN, Y. H. A apomixia das gramíneas forrageiras tropicais e subtropicais. In: SAVIDAN, Y; ALCÂNTARA, P. B.; VALLS, J. F. M. QUARÍN, C.; ALMEIDA, A. R. P. de (Ed.) ENCONTRO INTERNACIONAL SOBRE MELHORAMENTO DO GENERO Paspalum Nova Odessa, SP, 1987. Anais. Nova Odessa: Instituto de Zootecnia, 1987. p. 31-35.

SHEARD, R. W. Organic reserves and plant regrowth. In: BUTTLER, G. W.; BAILEY, R. W. (Ed.) Chemistry and biochemistry of herbage. London: Academic Press, 1973. v. 2, c.25, p. 353-377.

SIMÃO NETO, M. S. Sistemas de pastejo 2. In: PEIXOTO, A. M.; MOURA, J. C. de; FARIA, V. P. de (Ed.) SIMPÓSIO SOBRE MANEJO DA PASTAGEM, 8., Piracicaba, SP, 1986. Anais. Piracicaba: FEALQ, 1986. p. 291-308.

SKERMAN, P. J.; RIVEROS, F. Gramineas tropicales. Roma: FAO, 1992. 832 p. (Colección FAO: Producción y protección vegetal, 23)

SOEST, P. J. Van. Nutritional ecology of the ruminant. Corvallis: O \& B books, 1982. 374p.

SOTO, H. A. H. Um modelo simples de estimativa de produção de forragem para colonião (Panicum maximum Jacq.) e pangola A-24 (Digitana pentzii Stent) usando parâmetros climáticos. Piracicaba, 1981. 58p. Dissertação (Mestrado) - Escola Superior de Agricultura "Luiz de Queiroz", Universidade de São Paulo.

SPAIN, J. M; SALINAS, J. G. A reciclagem de nutrientes nas pastagens tropicais. In: CABALAROSAND, P. (Ed.) SIMPÓSIO SOBRE RECICLAGEM DE NUTRIENTES E AGRICULTURA DE BAIXOS INSUMOS NOS TRÓPICOS, Ilhéus, BA, 1984. Anais. Ilnéus: CEPLAC/SBCS, 1985. p. 259-300.

STANLEY, R. L.; BEATY, E. R.; POWELL, J. D. Forage yield and percent cell wall constituents of pensacola bahiagrass as related to $\mathrm{N}$ fertilization and clipping heigth. Agronomy Journal, v.69, n.3, p. 501-4, 1977.

STEEL, R. G. D \& TORRIE, J. H. Principles and procedures of statistics: a biometrical approach. New York: McGraw-Hill, 1960. 481p.

STOBBS, T. H. The effect of plant structure on the intake of tropical pastures. I. Variation of bite size of cattle. Australian Journal of Agricultural Research, v.24, p. 809-819, 1973a. 
STOBBS, T. H. The effect of plant structure on the intake of tropical pastures. II. Difference in sward structure, nutritive value, and bite size of animal grazing Setaria anceps and Chloris gayana at various stages of growth. Australian Journal of Agricultural Research, v.24, p. 821-829, $1973 b$.

SUAREZ, J. de D.; SUAREZ, J. J.; PIÑERO, M. Evaluacion de nueve gramineas tropicales bajo corte y secano en un suelo pardo tropical. Ciencia y Técnica en la Agricultura: Pastos y Forrages, v. 10, n.1, p. 21-34, 1987.

SUTCLIFFE, J. As plantas e a água. São Paulo: EPU, 1980. 126p.

USBERTI FILHO, J. A. 'IAC-Centauro' Novo cultivar de capim coloniào de porte baixo e ciclo precoce. In: SANTIAGO, A. da C; PACKER, I. U.; MOURA, J. C. (Ed.) CONGRESSO PAULISTA DE AGRONOMIA, 6.; Piracicaba, SP, 1987. Anais. Piracicaba: FEALQ, 1987. p. $149-162$.

VALLE, C. B. do; MILES, J. F. Melhoramento de gramíneas do gênero Brachiaria. In: PEIXOTO, A. M.; MOURA, J. C. de; FARIA, V. P. de (Ed.) SIMPÓSIO SOBRE MANEJO DA PASTAGEM, 11., Piracicaba, SP, 1994. Anais. Piracicaba: FEALQ, 1994. p. 1-24.

VALLS, J. F. M. \& CORADIN, L. Recursos genéticos de plantas forrageiras nativas do Brasil. In:SIMPÓSIO SOBRE PRODUÇÃO ANIMAL, 3., Corumbá, 1986. Anais. Campinas: Fundação Cargill, 1986. p. 19-34.

VALLS, J. F. M. \& POZZOBON, M. T. Variação apresentada pelos principais grupos taxonômicos de Paspalum com interesse forrageiro no Brasil. In: SAVIDAN, $Y$; ALCÂNTARA, P. B.; VALLS, J. F. M.; QUARÍN, C.; ALMEIDA, A. R. P. de (Ed.) ENCONTRO INTERNACIONAL SOBRE MELHORAMENTO DO GÊNERO Paspalum Nova Odessa, SP, 1987. Anais. Nova Odessa: Instituto de Zootecnia, 1987. p. 15-21.

VALLS, J. F. M. Origem do germoplasma de Paspalum disponivel no Brasil para a área tropical. In: PIZARRO. E. A. (Ed.) RED INTERNACIONAL DE EVALUACIÓN DE PASTOS TROPICALES REUNIÓN SABANAS, 1., Brasilia, DF, 1992. Memorias. Cali, Brasilia: CIAT, EMBRAPACPAC, 1992. p. 69-80 (CIAT - Documento de trabajo, 117).

VALLS, J. F. M. Potencial de plantas forrageiras tropicais americanas. In: BUTOLO, J. E. (Ed.) SIMPÓSIO BRASILEIRO DE FORRAGEIRAS E PASTAGENS, Campinas, SP, 1994. Anais. Campinas: CBNA, 1994. p. 11-24. 
VALLS, J. F. M. Principais gramíneas nativas das diferentes regiōes do Brasil. In: SIMPÓSIO SOBRE PRODUÇÃO ANIMAL, 3., Corumbá, 1986. Anais. Campinas: Fundação Cargill, 1986. p. $75-86$.

VICENTE-CHANDLER, J.;PEARSON, R. W.;ABRUÑA. F.;SILVA, S. Potassium fertilization of intensively managed grasses under humid tropical conditions. Agronomy Journal, v.54, n. 5, p. $450-453,1962$.

VICENTE-CHANDLER, J.;SILVA, S.;FIGARELLA, J. The effect of nitrogen fertilization and frequency of cutting on the yeld and composition of three tropical grasses. Agronomy Joumal, v.51, n.3, p. 202-206, 1959.

VICKERY, P. J. Pasture growth under grazing. In: MORLEY, F. H. W. (Ed.) Grazing animal. New York: Elsevier Scientific Publications, 1981. p. 55-77.

VIEIRA, J. D.; HAAG, H. P.; CORSI, M.; BOSE, M. L. V. Produção, coeficiente de digestibilidade da matéria seca e concentração de nutrientes em Panicum maximum Jacq., em função dos cortes aos 30, 45, 60 e 75 dias de idade. Anais da Escola Superior de Agricultura "Luiz de Queiroz", v.37, n.1, p. 419-441, 1980.

WERNER, J. C. Estudos sobre a nutrição mineral de alguns capins tropicais. Piracicaba, 1971. 95p. Tese (Doutorado) - Escola Superior de Agricultura "Luiz de Queiroz", Universidade de São Paulo.

WERNER, J. C. Adubação de pastagens. 2a. imp. Nova Odessa: Instituto de Zootecnia, 1986a. 49p. (Instituto de Zootecnia. Boletim Técnico, 18).

WERNER, J. C. Adubação potássica. In: MATTOS, H. B.; WERNER, J. C.; YAMADA, T. (Ed.) SIMPÓSIO SOBRE CALAGEM E ADUBAÇÃO DE PASTAGENS, 1., Nova Odessa, SP, 1985. Anais. Piracicaba: POTAFOS, 1986b. p. 383-419.

WILSON, J. R.; 't MANNETJE, L. Senescence, digestibility and carbohydrate content of buffel grass and green panic leaves in swards. Australian Journal of Agricultural Research, v. 29, p. $503-516,1978$.

YOUNGNER, V. B. Physiology of defoliation and regrowth. In: YOUNGNER, V. B; McKELL, C. M. (Ed.) The biology and utilization of grasses. New York: Academic Press, 1972. p. 292-303.

ZIMAMER FARIA, V. P. de (Ed.) SIMPÓSIO SOBRE MANEJO DA PASTAGEM, 8., Piracicaba, SP, 1986. Anais. Piracicaba: FEALQ, 1986. p. 323-350. 
ZIMMER, A. H.; CORREA, E. S. A pecuária nacional, uma pecuária de pasto ? In: PAULINO, V. T.; ALCÂNTARA, P. B. (Coord.) ENCONTRO SOBRE RECUPERAÇÃO DE PASTAGENS, 1., Nova Odessa, SP, 1993. Anais. Nova Odessa, SP: Instituto de Zootecnia, 1993. p. 126.

ZIMMER, A. H.; MACEDO, M. C. M.; BARCELLOS, A. de O; KICHEK, A. N. Estabelecimento e recuperação de pastagens de Brachiaria. In: PEIXOTO, A. M.; MOURA, J. C. de; FARIA, V. P. de (Ed.) SIMPÓSIO SOBRE MANEJO DA PASTAGEM, 11., Piracicaba, SP, 1994. Anais. Piracicaba: FEALQ, 1994. p. 153-208. 
APÊNDICE 
Tabela 19. Resumo da análise de variância para as regressões entre parâmetros da produçäo de forragem no Panicum maximum cV. Aruana em intervalos de crescimento (semanas). Entre parênteses :Quadrado médio do erro; Entre chaves: Média geral.

\begin{tabular}{|c|c|c|c|c|c|c|c|}
\hline \multirow[b]{2}{*}{ Componente } & & \multicolumn{6}{|c|}{ Causas de Variação } \\
\hline & & & Semanas & Semanas & Semanas & Semanas & \\
\hline da produçăo & Paråmetros & Bloco & Efeito linear & Efeito Quadrático & Efeito Cübico & Efeito Quártico & Erro \\
\hline Variável Resposta (Y) & Graus de liberdade & 2 & 1 & 1 & 1 & 1 & 8 \\
\hline$A L T$ & $F$ & 3,245 & 420,099 & 179,016 & 34,209 & 109,253 & $(27,25375)$ \\
\hline ALT & Probabilidade $>F$ & 0,0929 & 0,0001 & 0,0001 & 0,00038 & 0,0001 & $\{69,78\}$ \\
\hline MSC & $F$ & 0,361 & 116,291 & 12,844 & 6,033 & 0,675 & $(867972,3)$ \\
\hline MSC & Probabilidade $>F$ & 0,70763 & 0,0001 & 0,00715 & 0,03955 & 0,43501 & $\{2890,6\}$ \\
\hline MSFOR & $F$ & 0,488 & 151,677 & 31,646 & 0,818 & 1,013 & $(1842263,97)$ \\
\hline MSFOR & Probabilidade $>F$ & 0,63093 & 0,0001 & 0,0005 & 0,39214 & 0,34375 & $\{6985,2\}$ \\
\hline MSFORV & $F$ & 0,283 & 93,778 & 44,191 & 0,708 & 0,946 & $(1578062,1)$ \\
\hline MSFORV & Probabilidade $>F$ & 0,7605 & 0,0001 & 0,00016 & 0,42465 & 0,35928 & $\{6041,13\}$ \\
\hline MSFV & $F$ & 1,028 & 11,557 & 64,699 & 3,906 & 0,536 & $(388249,734)$ \\
\hline MSFV & Probabilidade $>F$ & 0,40067 & 0,00937 & 0,0001 & 0,08351 & 0,4851 & $\{3150,53\}$ \\
\hline MSPA & $F$ & 1,85 & 192,287 & 23,482 & 0,881 & 1,449 & $(2011930,6)$ \\
\hline MSPA & Probabilidade $>F$ & 0,21857 & 0,0001 & 0,00128 & 0,37548 & 0,26314 & $\{7948\}$ \\
\hline MSS & $F$ & 1,517 & 252,424 & 6,235 & 0,356 & 0,253 & $(82055,2838)$ \\
\hline MSS & Probabilidade $>F$ & 0,27638 & 0,0001 & 0,03712 & 0,56719 & 0,62841 & $\{944,06\}$ \\
\hline NP & $F$ & 1.037 & 15.592 & 0,011 & 2,412 & 1,202 & $(25130,1)$ \\
\hline NP & Probabilidade $>F$ & 0,3976 & 0,00424 & 0,9179 & 0,15905 & 0,30478 & $\{733,665\}$ \\
\hline$P C$ & $F$ & 0,54 & 471,39 & 101,72 & 0,77 & 19,5 & $(11,58625)$ \\
\hline$P C$ & Probabilidade $>F$ & 0,6003 & 0,0000 & 0,0001 & 0,40596 & 0,00224 & $\{26,675\}$ \\
\hline PEMA & $F$ & 0,59 & 123,02 & 53,85 & 49,57 & 3,95 & $(91,15)$ \\
\hline PEMA & Probabilidade $>F$ & 0,57517 & 0,0001 & 0,00008 & 0,00011 & 0,08205 & $\{65,53\}$ \\
\hline PFV & $F$ & 1,16 & 1568,02 & 111,54 & 0,68 & 42,76 & $(7,7675)$ \\
\hline PFV & Probabilidade $>F$ & 0,36085 & 0,0001 & 0,0001 & 0,43285 & 0,00018 & $\{65,24\}$ \\
\hline PMP & $F$ & 1.1 & 139,2 & 1,02 & 1,92 & 0 & $(0,17)$ \\
\hline PMP & Probabilidade $>F$ & 0,37731 & 0,0001 & 0,34193 & 0,20313 & 0,99258 & $\{1,413\}$ \\
\hline PS & $F$ & 0,11 & 197,5 & 3,57 & 0,07 & 1,52 & $(6,72875)$ \\
\hline PS & Probabilidade $>F$ & 0,89409 & 0,0001 & 0,09567 & 0,79857 & 0,25324 & $\{8,083\}$ \\
\hline & & & & & & & \\
\hline & & & & & & & \\
\hline & & & & & & & \\
\hline & & & & & & & \\
\hline & & & & Causas & de Variação & & \\
\hline Componente & & & Semanas & Semanas & Semanas & Semanas & \\
\hline da produçäo & Parâmetros & Bloco & Efeito linear & Efeito Quadrático & Efeito Cúbico & Efeito Quártico & Erro \\
\hline Variável Resposta (Y) & Graus de liberdade & 2 & 1 & 1 & 1 & - & 6 \\
\hline VR28 & $F$ & 0,0842 & 421.436 & 23.263 & 0,2474 & - & $(243275)$ \\
\hline VR28 & Probabilidade $>F$ & 0,92028 & 0,00064 & 0,00293 & 0,6366 & - & $\{1623\}$ \\
\hline & & & & & & & \\
\hline & & & & & & & \\
\hline $\begin{array}{l}\text { T = Altura da planta }(\mathrm{cm}) \\
\text { rde ; MSFV = Materia sec } \\
\text { Vúmero de perfithos basais } \\
\text { rilhos basais; PFV = Port } \\
\text { ragem; VR28 = Vigor da }\end{array}$ & roducto der & th & após o & . & b & $\begin{array}{l}\mathrm{R}=\text { Maté } \\
\text { material } \\
\text { naçăo de }\end{array}$ & $\begin{array}{l}\text { seca como forragem } \\
\text { escido }\left(\mathrm{kg} \mathrm{ha}^{-1}\right) \text {; } \mathrm{NP} \\
\text { ristermas apicais dos } \\
\text { aterial senescido na }\end{array}$ \\
\hline
\end{tabular}


Tabela 20. Resumo da análise de variância para as regressöes entre parâmetros da produção de forragem no Panicum maximum cV. IZ-1 em intervalos de crescimento (semanas). Entre parênteses :Quadrado médio do erro; Entre chaves: Média geral.

\begin{tabular}{|c|c|c|c|c|c|c|c|}
\hline & & \multicolumn{6}{|c|}{ Causas de Variação } \\
\hline Componente & \multirow[b]{2}{*}{ Parametros } & & Semanas & Semanas & \multirow{2}{*}{$\begin{array}{l}\text { Semanas } \\
\text { Efeito Cúbico }\end{array}$} & \multirow{2}{*}{\begin{tabular}{|c|} 
Semanas \\
Efeito Quártico
\end{tabular}} & \multirow[b]{2}{*}{ Erro } \\
\hline da produçâo & & Bloco & Efeito linear & Efeito Quadrático & & & \\
\hline Variável Resposta $(Y)$ & Graus de liberdade & 2 & 1 & 1 & 1 & 1 & 8 \\
\hline ALT & $\mathbf{F}$ & 1,496 & 510,178 & 5,045 & 6,360 & 1,703 & $(134,3225)$ \\
\hline$A L T$ & Probabilidade $>F$ & 0,281 & 0,0001 & 0,055 & 0,036 & 0,228 & $\{91,29\}$ \\
\hline MSDOR & $\mathbf{F}$ & 1,360 & 105,814 & 0,750 & 0,024 & 0,006 & $(9477724,63)$ \\
\hline MSFOR & Probabilidade $>F$ & 0,310 & 0,0001 & 0,412 & 0,882 & 0,941 & $\{8047\}$ \\
\hline MSFORV & $\mathbf{F}$ & 1,2 & 115,965 & 0,559 & 0,174 & 0,02 & $(5993860,6)$ \\
\hline MSFORV & Probabilidade $>F$ & 0,35 & 0,000001 & 0,476 & 0,688 & 0,8900 & $\{7005\}$ \\
\hline MSFV & $F$ & 0,980 & 121,641 & 5,326 & 0,026 & 0,006 & $(1888089,13)$ \\
\hline MSFV & Probabilidade $>F$ & 0,416 & 0,0001 & 0,050 & 0,875 & 0,942 & $\{5122\}$ \\
\hline MSPA & $F$ & 0,665 & 76,544 & 0,043 & 0,077 & 0,002 & $(11439938,5)$ \\
\hline MSPA & Probabilidade $>F$ & 0,541 & 0,0001 & 0,841 & 0,789 & 0,968 & $\{8995\}$ \\
\hline NP & $F$ & 1,024 & 27,998 & 12,322 & 22,429 & 3,989 & $(760,61625)$ \\
\hline NP & Probabilidade $>F$ & 0,402 & 0,001 & 0,008 & 0,001 & 0,081 & $\{175,93\}$ \\
\hline $\mathrm{PC}$ & $F$ & 0,790 & 473,790 & 37,660 & 6,190 & 4,610 & $(5,07625)$ \\
\hline PC & Probabilidade $>F$ & 0,486 & 0,0001 & 0,0001 & 0,038 & 0,064 & $\{10,04\}$ \\
\hline PFV & $F$ & 2,560 & 671,570 & 6,660 & 0,580 & 2,780 & $(8,1275)$ \\
\hline PFV & Probabilidade $>F$ & 0,138 & 0,0001 & 0,033 & 0,470 & 0,134 & $\{83,63\}$ \\
\hline PMP & $F$ & 1,450 & 1263,310 & 79,390 & 0,770 & 0,010 & $(0,79625)$ \\
\hline PMP & Probabilidade $>F$ & 0,290 & 0,0001 & 0,0001 & 0,407 & 0,914 & $\{7,13\}$ \\
\hline PS & $F$ & 2,040 & 130,890 & 8,890 & 12,810 & 0,0001 & $(4,71125)$ \\
\hline PS & Probabilidade $>F$ & 0,193 & 0,0001 & 0,018 & 0,007 & 0,968 & $\{6,32\}$ \\
\hline VR28 & $\mathbf{F}$ & 0,890 & 3,090 & 0,060 & 0,970 & 0,430 & $(361422,016)$ \\
\hline VR 28 & Probabilidade $>F$ & 0,448 & 0,117 & 0,807 & 0,353 & 0,532 & $\{1816\}$ \\
\hline & & & & & & & \\
\hline & & & & & & & \\
\hline & & & & & & & \\
\hline & & & & Causas & is de Variaçăo & & \\
\hline Componente & & & Semanas & Semanas & Semanas & Semanas & \\
\hline da produçấo & Parametros & Bloco & Efeito linear & rEfeito Quadrático & Efeito Cúbico & Efeito Quártico & Erro \\
\hline Variável Resposta $(Y)$ & Graus de liberdade & 2 & 1 & 1 & - & - & 4 \\
\hline MSC & $F$ & 1.172 & 41,412 & 5,873 & - & - & $(2470368,7)$ \\
\hline MSC & Probabilidade $>F$ & 0,397 & 0,0030 & 0,072 & - & - & $\{3138\}$ \\
\hline MSS & $F$ & 1,677 & 48,154 & 1,197 & - & - & $(841854,6)$ \\
\hline MSS & Probabilidade $>F$ & 0,246 & 0,0001 & 0,306 & - & - & $\{1737\}$ \\
\hline & & & & & & & \\
\hline & & & & & & & \\
\hline & & & & & & & \\
\hline & & & & & & & \\
\hline & & & & Causas & s de Variaçáo & & \\
\hline Componente & & & Semanas & Semanas & Semanas & Semanas & \\
\hline da produçáo & Parâmetros & Bloco & Efeito linear & Efeito Quadrático & Efeito Cúbico & Efeito Quártico & Erro \\
\hline Variável Resposta (Y) & Graus de liberdade & 2 & 1 & 1 & 1 & - & 6 \\
\hline PEMA & $\mathrm{F}$ & 1,002 & 1394,380 & 323,210 & 39,560 & - & $(14,58)$ \\
\hline PEMA & Probabilidade $>F$ & 0,422 & 0,000001 & 0,000001 & 0,0008 & - & $\{54,16\}$ \\
\hline & & & & & & & \\
\hline $\begin{array}{l}\text { ALT = Altura da planta }(\mathrm{cm}) \text {; } \\
\text { verde ; MSFV = Materia sec } \\
\text { = Número de perfithos basais } \\
\text { perfilhos basais; PFV = Por } \\
\text { forragem ; VR28 = Vigor da }\end{array}$ & ta-producto de maté & 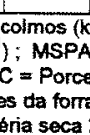 & $\begin{array}{l}\text { jem de colm } \\
n ; \text { PMP = F } \\
\text { lias apos oc }\end{array}$ & $\begin{array}{l}\text { a forragem ; PEMA } \\
\text { médio dos perfilhos } \\
\mathrm{kg} \mathrm{ha}^{-1} \text {. }\end{array}$ & $\begin{array}{l}\text { em }\left(\mathrm{kg} \mathrm{ha}^{-1}\right) ; \mathrm{N} \\
\text { MSS = Materia S } \\
=\text { Porcentagem de } \\
\text { basais }(\mathrm{g}) ; \mathrm{PS}=\end{array}$ & $\begin{array}{l}\text { MSFORV = Matérias } \\
\text { seca de matorial sent } \\
\text { de eliminaçádo de mer } \\
\text { = Porcentagem de me }\end{array}$ & $\begin{array}{l}\text { seca como forragen } \\
\text { risternas apicais do } \\
\text { resterial senescido n }\end{array}$ \\
\hline
\end{tabular}


Tabela 21. Resumo da análise de variância para as regressões entre parâmetros da produção de forragem no Paspalum coryphaeum NO $174 \mathrm{em}$ intervalos de crescimento (semanas). Entre parênteses :Quadrado médio do erro; Entre chaves: Média geral.

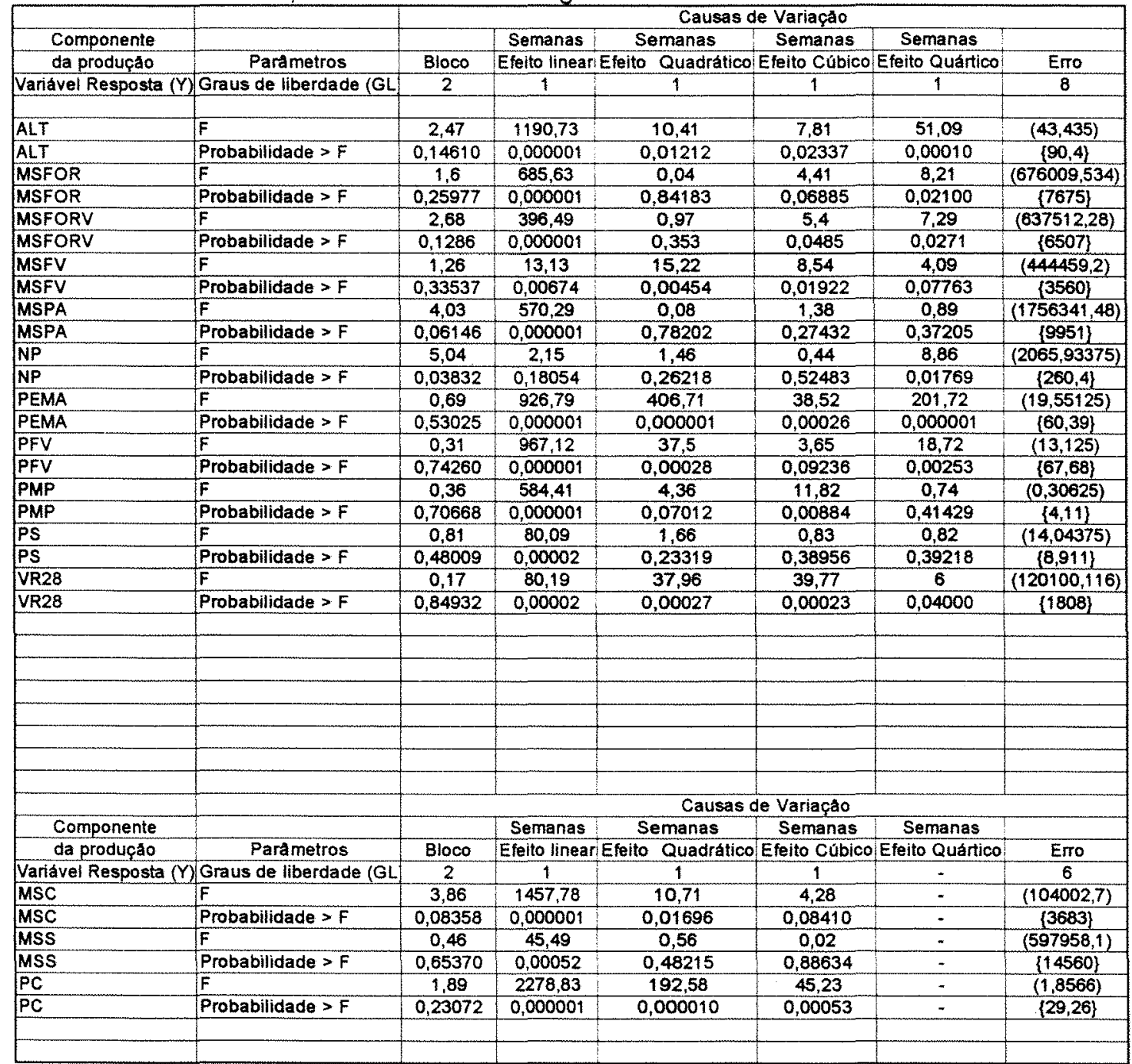

ALT = Altura da planta (cm); MSC = Matéria seca de colmos $\left(\mathrm{kg} \mathrm{ha}^{-1}\right) ;$ MSFOR = matéria seca da forragem (kg ha $) ; M S F O R V=$ Matória seca como forragem verde; MSFV = Materia seca de folhas verde $\left(\mathrm{kg} \mathrm{ha}^{-1}\right)$; MSPA = Materia seca da parte derea (kg ha ${ }^{-1}$ ); MSS = Materia seca de material senescido $\left(\mathrm{kg} \mathrm{ha}^{-1}\right) ; \mathrm{NP}=$ Número de perfilhos basais por metro quadrado $\mathrm{PC}=$ Porcentagem de colmos na forragem ; PEMA = Porcentagem de eliminaça de meristemas apicais dos perfilhos basais; PFV = Porcentagem de folhas verdes da forragem; PMP = Peso medio dos perfilhos basais (g); PS = Porcentagem de material senescido na forragem; VR28 = Vigor da rebrota-produçăo de materia seca 28 dias apos o corte (kg ha ${ }^{-1}$ ). 
Tabela 22. Resumo da análise de variância para as regressões entre teores de nutrientes minerais na forragem do Panicum maximum cultivar Aruana em intervalos de crescimento (semanas). Entre parênteses :Quadrado médio do erro; Entre chaves: Média geral. Em g $\left(100 \mathrm{~g}^{-1}=\mathrm{N}, \mathrm{P}, \mathrm{K}, \mathrm{Ca}, \mathrm{Mg}\right.$ e S; Em mg kg${ }^{-1}=\mathrm{B}, \mathrm{Cu}, \mathrm{Fe}, \mathrm{Mn}$ e Zn.

\begin{tabular}{|c|c|c|c|c|c|c|c|}
\hline \multicolumn{2}{|c|}{ Folhas Verdes } & \multicolumn{6}{|c|}{ Causas de Vanacato } \\
\hline Nutriente & & & Semanas & Semanas & Semanas & Semanas & \\
\hline Variável Resposta (M) & Parâmetos & $B 1000$ & Efeito linear & Efeito Quadrático & Efeito Cúbico & Efeito Quartico & Erro \\
\hline 422 Sermanas & Graus de Liberdade (GL & 2 & 1 & 1 & 1 & 1 & 8 \\
\hline $\mathbf{N}$ & $F$ & 1,281 & 853,00 & 250,86 & 13,51 & 7,52 & $(0,01375)$ \\
\hline $\mathrm{N}$ & Probabilicado $>F$ & 0,329 & 0,0001 & 0,0001 & 0,006 & 0,025 & $\{2,283\}$ \\
\hline$P$ & $F$ & 2,630 & 33,79 & 95,96 & 0,71 & 0,72 & $(0,000362)$ \\
\hline$P$ & Probabilicade $>F$ & 0,132 & 0,0004 & 0,0001 & 0,424 & 0,422 & $\{0,276\}$ \\
\hline$K$ & $F$ & 0,060 & 190,57 & 3,05 & 6,87 & 7,18 & $(0,02375)$ \\
\hline $\mathrm{K}$ & Probabilictade $>F$ & 0,942 & 0,000 & 0,119 & 0,031 & 0,028 & $\{2,691\}$ \\
\hline Ca & $F$ & 0,087 & 18,54 & 4,51 & 0,001 & 0,54 & $(0,0025)$ \\
\hline $\mathrm{Ca}$ & Probabilidade $>F$ & 0,918 & 0,003 & 0,067 & 0,970 & 0,485 & $\{0,511\}$ \\
\hline $\mathrm{Mg}$ & $F$ & 0,002 & 0,91 & 7,49 & 4,32 & 1,17 & $(0,0025)$ \\
\hline $\mathrm{Mg}$ & Probabilidade $>F$ & 0,998 & 0,369 & 0,026 & 0,071 & 0,312 & $\{0,341\}$ \\
\hline $\mathbf{s}$ & $F$ & 0,277 & 93,84 & 20,49 & 9,25 & 4,63 & $(0,000125)$ \\
\hline S & Probabilidade $>F$ & 0,765 & 0,0001 & 0,002 & 0,016 & 0,064 & $\{0,24\}$ \\
\hline$B$ & $F$ & 2,684 & 6,77 & 2,34 & 0,20 & 0,56 & $(0,9875)$ \\
\hline B & Probabilidade $>F$ & 0,128 & 0,032 & 0,165 & 0,668 & 0,477 & $\{4,231\}$ \\
\hline Cu & $F$ & 4,780 & 595,30 & 168,58 & 1,39 & 4,10 & $(0,20125)$ \\
\hline $\mathrm{Cu}$ & Probabilidade $>F$ & 0,043 & 0,0001 & 0,0001 & 0,272 & 0,078 & $(9,856)$ \\
\hline$F_{\theta}$ & $F$ & 0,025 & 1,60 & 32,93 & 20,39 & 2,86 & $(155,58)$ \\
\hline $\mathrm{Fe}$ & Probabilidade $>F$ & 0,975 & 0,242 & 0,0004 & 0,002 & 0,129 & $\{148,04\}$ \\
\hline $\mathrm{m}$ & $F$ & 0,608 & 5,17 & 2,81 & 2,75 & 0,10 & $(962,665)$ \\
\hline$M n$ & Probabiliclade $>F$ & 0,568 & 0,053 & 0,132 & 0,136 & 0,762 & $\{191,34\}$ \\
\hline $\mathrm{Zn}$ & $F$ & 0,774 & 23,05 & 4,11 & 7,71 & 3,59 & $(4,145)$ \\
\hline Zn & Probabilidade $>F$ & 0,493 & 0,001 & 0,077 & 0,024 & 0,005 & 26,557 \\
\hline & & & & & & & \\
\hline & & & & Causas & Variaçăo & & \\
\hline & olmos & & & & & & \\
\hline Nutriente & & & Semanas & Sermanas & Semaras & Semanas & \\
\hline Variável Resposta (Y) & Parâmetros & Bloco & Efeito linear & Efeito Quadrático & Efeito Cúbico & Efeito Quártico & Eno \\
\hline 6-22 Semanas & Graus de Liberdade (GL) & 2 & 1 & 1 & 1 & - & 6 \\
\hline $\mathbf{N}$ & F & 2509 & & 500 & 50 & & (n) \\
\hline $\mathrm{N}$ & Probabilicade $>F$ & 0,154 & 0,0001 & 0,0003 & 0,059 & - & $\frac{\{, 790\}}{\{0,798\}}$ \\
\hline & & & & & & & \\
\hline & & & & & & & \\
\hline Forrag & gem Verde & & & Causas & Variação & & \\
\hline & & & & & & & \\
\hline \begin{tabular}{|c|} 
Nutriente \\
Variável Resposta (Y)
\end{tabular} & Parámetros & Błoco & $\begin{array}{l}\text { Serranas } \\
\text { Efeito linear }\end{array}$ & $\begin{array}{l}\text { Semanas } \\
\text { Efeito Quadrátioo }\end{array}$ & $\begin{array}{l}\text { Semanas } \\
\text { Efeito Cúbico }\end{array}$ & Efeito Quáritico & Ето \\
\hline 4-22 Semanas & Graus de Liberdade (GL) & 2 & 1 & 1 & 1 & 1 & 8 \\
\hline $\mathrm{N}$ & IF & 1,710 & 1308,38 & 343,53 & 26.40 & 0,27 & $(0,01313)$ \\
\hline $\mathbf{N}$ & Probabilidade $>F$ & 0,240 & 0,0001 & 0,0001 & 0,0009 & 0,618 & $\{1,988\}$ \\
\hline
\end{tabular}


Tabela 23. Resumo da análise de variância para as regressões entre teores de nutrientes minerais na forragem do Panicum maximum cultivar $\mathrm{IZ}-1$ e intervalos de crescimento (semanas). Entre parênteses: Quadrado médio do erro; Entre chaves: Média geral. $\mathrm{Em} \mathrm{g}(100 \mathrm{~g})^{-1}=\mathrm{N}, \mathrm{P}, \mathrm{K}, \mathrm{Ca}, \mathrm{Mg}$ e S; $\mathrm{Em} \mathrm{mg} \mathrm{kg}^{-1}=\mathrm{B}, \mathrm{Cu}, \mathrm{Fe}, \mathrm{Mn}$ e Zn.

\begin{tabular}{|c|c|c|c|c|c|c|c|}
\hline \multicolumn{2}{|c|}{ Folhas Verdes } & & & & & & \\
\hline & & \multicolumn{6}{|c|}{ Causas de Variação } \\
\hline Nutriente & & & Somanas & Semanas & Semanas & Semanas & \\
\hline Variável Resposta $(Y)$ & Parámetros & Bloco & Efeito lineart & Efeito Quadratico & Efeito Cúbico & Efeito Quártico & Erro \\
\hline 4-22 Semanas & Graus de Liberdade (GL) & 2 & 1 & 9 & 1 & 1 & 8 \\
\hline $\mathbf{N}$ & $F$ & 0,492 & 929,853 & 345,441 & 72,714 & 1,739 & $(0,01625)$ \\
\hline $\mathbf{N}$ & Probabilidade $>F$ & 0,6287 & 0,0001 & 0,0001 & 0,0001 & 0,22372 & $\{1,814\}$ \\
\hline Proteina Bruta & $F$ & 0,492 & 929,853 & 345,441 & 72,714 & 1,739 & $(0,6225)$ \\
\hline Proteina Bruta & Probabilidade $>F$ & 0,6287 & 0,0001 & 0,0001 & 0,00003 & 0,22372 & $\{11,323\}$ \\
\hline$P$ & $F$ & 0,054 & 650,38 & 144,383 & 9,737 & 14,202 & $(0,0000138)$ \\
\hline$P$ & Probabilidade $>F$ & 0,9477 & 0,0001 & 0,0001 & 0,01422 & 0,00548 & $\{0,206\}$ \\
\hline$k$ & $F$ & 0,869 & 143,209 & 0,772 & 17,061 & 6,136 & $(0,03375)$ \\
\hline $\mathrm{K}$ & Probabilidade $>\mathrm{F}$ & 0,4554 & 0,0001 & 0,40534 & 0,0033 & 0,03828 & $\{3,295\}$ \\
\hline $\mathrm{Ca}$ & $F$ & 0,193 & 0,359 & 3,486 & 0,00000017 & 0,317 & $(0,00059)$ \\
\hline $\mathrm{Ca}$ & Probabilidade $>F$ & 0,8281 & 0,56548 & 0,09887 & 0,98711 & 0,589 & $\{0,35\}$ \\
\hline $\mathrm{Mg}$ & $F$ & 3,369 & 64,305 & 8,364 & 2,067 & 0,001 & $(0,0001913)$ \\
\hline $\mathrm{Mg}$ & Probabilidade $>F$ & 0,0868 & 0,00004 & 0,02014 & 0,1885 & 0,98062 & $\{0,181\}$ \\
\hline$S$ & $F$ & 2,087 & 472,846 & 131,323 & 18,307 & 1,172 & $(0,0000613)$ \\
\hline s & Probabilidade $>F$ & 0,1865 & 0,0001 & 0,0001 & 0,00269 & 0,3106 & $\{0,147\}$ \\
\hline$B$ & $\mathrm{~F}$ & 1,852 & 3,892 & 5,877 & 0,56 & 1,474 & $(1,32125)$ \\
\hline \multirow{2}{*}{$\begin{array}{l}\mathrm{B} \\
\mathrm{Cu}\end{array}$} & Probabilidade $>F$ & 0,2183 & 0,08398 & 0,04157 & 0,47578 & 0,25941 & $\{2,456\}$ \\
\hline & $F$ & 1,106 & 863,685 & 266,011 & 32,038 & 3,713 & $(0,23125)$ \\
\hline $\mathrm{Cu}$ & Probabilidade $>F$ & 0,3765 & 0,0001 & 0,0001 & 0,00048 & 0,09016 & $\{8,659\}$ \\
\hline \multirow{2}{*}{$\begin{array}{l}\mathrm{Fe} \\
\mathrm{Fe}\end{array}$} & $F$ & 2,421 & 25,998 & 15,454 & 6,337 & 0,025 & $(841,30375)$ \\
\hline & Probabilidade $>F$ & 0,1506 & 0,00093 & 0,00435 & 0,03595 & 0,87808 & $\{142,644\}$ \\
\hline $\mathrm{Mn}$ & $F$ & 7,077 & 21,46 & 3,902 & 0,711 & 0,058 & $(1179,9638)$ \\
\hline \multirow{2}{*}{\begin{tabular}{|l|}
$\mathrm{Mn}$ \\
$\mathrm{Zn}$
\end{tabular}} & Probabilidade $>F$ & 0,017 & 0,00168 & 0,08365 & 0,42364 & 0,81587 & $\{233,33\}$ \\
\hline & $F$ & 1,303 & 232,144 & 98,163 & 9,851 & 2,797 & $(2,59925)$ \\
\hline \multirow[t]{2}{*}{$2 n$} & Probabilidade $>F$ & 0,3237 & 0,0001 & 0,0001 & 0,01383 & 0,13299 & $\{20,471\}$ \\
\hline & & & & & & & \\
\hline \multicolumn{2}{|c|}{ Colmos } & & & & & & \\
\hline \multirow{4}{*}{\begin{tabular}{|c|} 
Nutriente \\
Variável Resposta (Y) \\
8-22 Semanas \\
\end{tabular}} & & \multicolumn{6}{|c|}{ Causas de Variação } \\
\hline & & & Semanas & Semanas & Semanas & Semanas & \\
\hline & Parâmetros & Bloco & Efeito linear & Efeito Quadrático & Efeito Cúbico & Efeito Quártico & Erro \\
\hline & Graus de Liberdade (GL) & 2 & 1 & 1 & - & - & 4 \\
\hline $\mathrm{N}$ & $\mathrm{F}$ & 0,916 & 117,036 & 1,748 & E & - & 25) \\
\hline \multirow[t]{2}{*}{$\mathrm{N}$} & Probabilidade $>F$ & 0,4705 & 0,00041 & 0,25669 & - & - & $\{0,609\}$ \\
\hline & & & & & & & \\
\hline \multicolumn{2}{|c|}{ Forragem Verde } & \multirow{2}{*}{\multicolumn{6}{|c|}{ Causas de Variação }} \\
\hline Nutriente & & & Semanas & Semanas & & Semanas & \\
\hline Variável Resposta (Y) & Parâmetros & Bloco & Efeito linear & Efeito Quadrático & Efeito Cúbico & Efeito Quártico & Erro \\
\hline 4-22 Semanas & Graus de Liberdade (GL) & 2 & 1 & 1 & 1 & 1 & 8 \\
\hline $\mathrm{N}$ & $F$ & 0,56 & 1068,43 & 330,17 & 82,13 & 2,45 & $(0,0154152)$ \\
\hline $\mathrm{N}$ & Probabilidade $>F$ & 0,5917 & 0,0001 & 0,0001 & 0,0001 & 0,1564 & $\{1,77098\}$ \\
\hline
\end{tabular}


Tabela 24. Resumo da análise de variância para as regressões entre teores de nutrientes minerais na forragem do Paspalum coryphaeum NO 174 e intervalos de crescimento (semanas). Entre parênteses: Quadrado médio do erro; Entre chaves: Média geral. $\mathrm{Em} \mathrm{g}\left(100 \mathrm{~g}^{-1}=\mathrm{N}, \mathrm{P}, \mathrm{K}, \mathrm{Ca}, \mathrm{Mg}\right.$ e S; $\mathrm{Em} \mathrm{mg} \mathrm{kg}^{-1}=\mathrm{B}, \mathrm{Cu}, \mathrm{Fe}, \mathrm{Mn}$ e $\mathrm{Zn}$.

\begin{tabular}{|c|c|c|c|c|c|c|c|}
\hline \multicolumn{2}{|c|}{ Folhas Verdes } & & & & & & \\
\hline & & \multicolumn{6}{|c|}{ Causas de Variaçāo } \\
\hline Nutriente & & & Semanas & Semanas & Semanas & Semanas & \\
\hline Variável Resposta $(Y)$ & Parâmetros & Bloco & Efeito linear & Efeito Quadrático & Efeito Cúbico & Efeito Quártico & Erro \\
\hline 4-22 Semanas & GL & 2 & 1 & 1 & 1 & 1 & 8 \\
\hline $\mathrm{N}$ & $F$ & 3.970 & 297.044 & 53,604 & 69.897 & 3097 & $(001)$ \\
\hline $\mathrm{N}$ & Probabilidade $>F$ & 0,063 & 0,0001 & 0,00008 & 0,00003 & 0,116 & $\{1,828\}$ \\
\hline$P$ & $\mathrm{~F}$ & 1,185 & 238,785 & 166,301 & 47,563 & 23,351 & $(0,000106)$ \\
\hline$P$ & Probabilidade $>F$ & 0,354 & 0,0001 & 0,0001 & 0,00012 & 0,001 & $\{0,221\}$ \\
\hline $\mathrm{K}$ & $\mathrm{F}$ & 4,015 & 215,196 & 3,503 & 10,027 & 0,861 & $(0,01)$ \\
\hline$K$ & Probabilidade $>F$ & 0,062 & 0,0001 & 0,098 & 0,013 & 0,381 & $\{2,219\}$ \\
\hline $\mathrm{Ca}$ & $F$ & 2,717 & 30,845 & 13,474 & 0,185 & 0,016 & $(0,0001341)$ \\
\hline $\mathrm{Ca}$ & Probabilidade $>F$ & 0,126 & 0,001 & 0,006 & 0,678 & 0,902 & $\{0,253\}$ \\
\hline $\mathrm{Mg}$ & $F$ & 6,332 & 25,146 & 16,900 & 6,396 & 0,154 & $(0,0001126)$ \\
\hline $\mathrm{Mg}$ & Probabilidade $>F$ & 0,022 & 0,001 & 0,003 & 0,035 & 0,705 & $\{0,244\}$ \\
\hline $\mathrm{S}$ & $F$ & 0,889 & 12,428 & 3,509 & 0,053 & 0,990 & $(0,000125)$ \\
\hline S & Probabilidade $>F$ & 0,448 & 0,008 & 0,098 & 0,824 & 0,349 & $\{0,165\}$ \\
\hline B & $F$ & 1,894 & 8,023 & 11,297 & 0,550 & 4,336 & $(0,73875)$ \\
\hline $\bar{B}$ & Probabilidade $>F$ & 0,212 & 0,022 & 0,010 & 0,480 & 0,071 & $\{2,572\}$ \\
\hline $\mathrm{Cu}$ & $F$ & 1,229 & 9,190 & 9,418 & 3,136 & 0,091 & $(1,07375)$ \\
\hline $\mathrm{Cu}$ & Probabilidade $>F$ & 0,342 & 0,016 & 0,015 & 0,115 & 0,770 & $\{9,42\}$ \\
\hline $\mathrm{Fe}$ & $F$ & 1,714 & 20,805 & 2,370 & 3,057 & 0,000 & $(383,23125)$ \\
\hline $\mathrm{Fe}$ & Probabilidade $>F$ & 0,240 & 0,002 & 0,162 & 0,119 & 0,999 & $\{119,166\}$ \\
\hline $\mathrm{Mn}$ & $F$ & 4,018 & 4,248 & 8,593 & 2,924 & 2,336 & $(1686,565)$ \\
\hline $\mathrm{Mn}$ & Probabilidade $>F$ & 0,062 & 0,073 & 0,019 & 0,126 & 0,165 & $\{321,775\}$ \\
\hline $\mathrm{Zn}$ & $F$ & 1,865 & 3,001 & 8,208 & 0,891 & 4,101 & $(16,383125)$ \\
\hline $\mathrm{Zn}$ & Probabilidade $>F$ & 0,216 & 0,121 & 0,021 & 0,373 & 0,077 & $\{32,246\}$ \\
\hline & & & & & & & \\
\hline \multicolumn{2}{|c|}{ Colmos } & \multicolumn{6}{|c|}{ Causas de Variação } \\
\hline Nutriente & & & Semanas & Semanas & Semanas & Semanas & \\
\hline Variável Resposta (Y) & Parámetros & Bloco & Efeito linear & Efeito Quadrático & Efeito Cúbico & Efeito Quártico & Erro \\
\hline 6-22 Semanas & Graus de liberdade (GL) & 2 & 1 & 1 & 1 & - & 6 \\
\hline $\mathrm{N}$ & $F$ & 1,143 & 80,1972 & 17,734 & 20,418 & - & $(0,04616667)$ \\
\hline \multirow[t]{2}{*}{$\mathrm{N}$} & Probabilidade $>F$ & 0,380 & 0,0001 & 0,006 & 0,004 & - & $\{1,032\}$ \\
\hline & & & & & & & \\
\hline \multicolumn{2}{|c|}{ Forragem Verde } & \multicolumn{6}{|c|}{ Causas de Variação } \\
\hline Nutriente & & & Semanas & Semanas & Semanas & Semanas & \\
\hline Variável Resposta (Y) & Parâmetros & Bloco & Efeito linear & Efeito Quadrático & Efeito Cúbico & Efeito Quártico & Erro \\
\hline 4-22 Semanas & $G L$ & 2 & 1 & 1 & 1 & 1 & 8 \\
\hline & & & & & & & \\
\hline$N$ & $\mathrm{~F}$ & 8,810 & 879,960 & 101,800 & 71,070 & 0,890 & $(0,0079296)$ \\
\hline$N$ & Probabilidade $>F$ & 0,010 & 0,0001 & 0,00010 & 0,00010 & 0,373 & $\{1,59759\}$ \\
\hline
\end{tabular}

